1998

\title{
Building Set Pieces in Eighteenth-Century Rome: The Case of the Chinea
}

John E. Moore

Smith College, jmoore@smith.edu

Follow this and additional works at: https://scholarworks.smith.edu/art_facpubs

Part of the Arts and Humanities Commons

\section{Recommended Citation}

Moore, John E., "Building Set Pieces in Eighteenth-Century Rome: The Case of the Chinea" (1998). Art: Faculty Publications, Smith College, Northampton, MA.

https://scholarworks.smith.edu/art_facpubs/19 


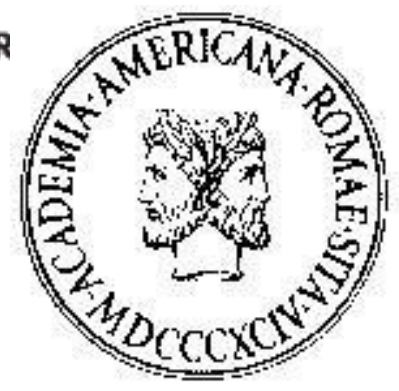

\section{BUILDING SET PIECES IN EIGHTEENTH-CENTURY ROME: THE CASE OF THE CHINEA}

\section{Author(s): John E. Moore}

Source: Memoirs of the American Academy in Rome, Vol. 43/44 (1998/1999), pp. 183-292

Published by: University of Michigan Press for the American Academy in Rome

Stable URL: https://www.jstor.org/stable/4238761

Accessed: 29-03-2019 17:01 UTC

JSTOR is a not-for-profit service that helps scholars, researchers, and students discover, use, and build upon a wide range of content in a trusted digital archive. We use information technology and tools to increase productivity and facilitate new forms of scholarship. For more information about JSTOR, please contact support@jstor.org.

Your use of the JSTOR archive indicates your acceptance of the Terms \& Conditions of Use, available at https://about.jstor.org/terms

University of Michigan Press, American Academy in Rome are collaborating with JSTOR to digitize, preserve and extend access to Memoirs of the American Academy in Rome 


\title{
BUILDING SET PIECES IN EIGHTEENTH-CENTURY ROME: THE CASE OF THE CHINEA
}

\author{
Jobn E. Moore
}

\section{Introduction}

$\mathrm{R}$ oman festivals of the early modern period have been the subject of several recent studies and exhibitions. ${ }^{1}$ Set pieces (macchine in Italian) erected for these festivals gave visual expression to the religious and social life of the time through the spectacular transformation of streets, squares, palaces, and churches. Events that gave rise to large-scale ephemeral constructions included jubilees, saints' days, canonizations, Forty Hours' devotions, elevations to the cardinalate, the coronation of a newly elected pope, and the possession of his bishop's seat at the Lateran. In addition to such local ecclesiastical rituals, the weddings, births, and deaths of the reigning Catholic monarchy, as well as celebrations of their victories and peace treaties, spurred ambassadors resident in Rome to sponsor magnificent displays that expressed the wealth and power of the absent sovereigns.

Each year on 28 June, the vigil of the feast of Sts. Peter and Paul, the pope received various feudal homages, either at the Quirinal Palace or at St. Peter's Basilica, where he might preside at Vespers service on the vigil and high mass on the feast day. The pope thus received homage on the eve of the day that commemorated the lives and ministries of two men upon whom the papacy had based its claims to spiritual and temporal authority since at least the days of Constantine. Among these homages, the presentation known as the Chinea was exceptional for its splendor and scale as well as its long history.

The chinea ("ambling nag") was a white horse that, together with a monetary tribute, had been delivered by ambassadors extraordinary of the ruling houses of the Two Sicilies since the eleventh century. ${ }^{2}$ The first presentation, dating to the Norman hegemony in southern

I am grateful to the American Academy in Rome, which awarded me a Rome Prize Fellowship in 1984-85, to Smith College for generous support of my research over several years, and to Kevin Salatino for his encouragement and assistance.

When relevant, both asking and audited prices of goods and services are provided in the notes, the former before the virgule, the latter following it. References to "jugs" (boccali) (of wine) and "loaves" (pagnotte) (of bread) below, when not otherwise specified, correspond respectively to documents at AC, I.A.438/155 ("Ristretto Di tutto il Vino esitato da Pietro della Bitta Canevaro . . . dal pmo Gennaro, à tt:o li 31 Dicembre 1759"), and AC, I.A.437/142 ("Ristretto delli Spogli mensuali del Pane à Dicine esitato d'Alberto Ludovisi Disp.re . . dal pmo Gen.ro, a tt.o li 31 Dicembre 1759"). There were 4 fogliette to the jug, each amounting to just under half a liter. A loaf of bread weighed 8 Roman ounces (oncie), or about 226 grams; see Gross, 182 (where the relevant decimal point is misplaced); and Scavizzi, 12. One foglietta and one loaf were considered adequate for each individual taking meals in the servants' dining room (tinello); Liberati, 121. Unless otherwise noted, all translations are my own.

${ }^{1}$ Salatino; M. Fagiolo, ed., Il Settecento e l'Ottocento, vol. 2 of Corpus delle feste a Roma (Rome 1997); Fagiolo dell'Arco; Gori Sassoli.

${ }^{2}$ Quoted definition in A Dictionary of the English and Italian Language, by J. Baretti (London 1760), s.v. Nugent, 2:121, translates Grosley's baquenée as "pad"; 
Italy, was an important display of fealty to the pope during a time of political insecurity. An eighteenth-century pamphlet explains that the Chinea originated in a meeting between Pope Nicholas II and Robert Guiscard; during their encounter, the Norman ruler agreed to do two things that would demonstrate his loyalty to the papacy. First, Guiscard offered his wealth and properties "to the throne of St. Peter." The pope returned that patrimony for "a trifling annual recognition" that would have the force of protecting the secular monarch from excommunication. Second, Guiscard chose St. Peter as his patron, a choice that, as the text implies, was politically expedient. He voluntarily offered the saint "an annual tribute" in the form of " 12 denarii of Pavia" for every team of oxen in the realm, and, in addition, he swore to "protect the pope and the patrimony of St. Peter."

Unlike other tokens of homage, the horse of the Chinea was usually not presented to the pope in private but was led through the tortuous streets of Rome in a splendid procession witnessed by the populace of the city that came to a halt in the very nave of St. Peter's between the two holy water stoups, at the feet of the pontiff borne high in his gestatorial chair. When the Holy See stood vacant, other homages could be received by the Reverend Apostolic Chamber; the Chinea alone was deferred until that holy seat was once again occupied. ${ }^{4}$

From 1689 on, the eldest prince of the Roman Colonna family, as "grand constable of the kingdom of Naples," held a virtual monopoly on the office of ambassador extraordinary for the presentation of the Chinea, which offered his family sizable financial benefits, more than offsetting the cost of putting on the two-day festival that accompanied the diplomatic act. ${ }^{5}$ Such continuous patronage is unique in the history of Roman festivals.

French original in Grosley, 3:53. The Italian chinea derives from the Old French baquenée, for which see Dictionnaire de l'ancienne langue française et de tous ses dialectes du IXe au XVe siècle, by F. Godefroy, facsimile ed. (Nendeln 1969), s.v.

${ }^{3}$ See Origine, progressi, e fine delle pontificie investiture, n.d., n.p, 15. This work appeared in or immediately after 1788 , when there emerged a spate of polemical literature-including histories hundreds of pages long with full scholarly apparatus-that discussed the suspension of the Chinea and sought to expound upon and justify the competing pretentions of the Neapolitan crown and the Holy See. Much of this literature is conveniently gathered in a bound volume (BAV, RG Storia IV.7769). For a listing of ambassadors extraordinary and accounts of presentations of the Chinea, see the manuscript compilation of Giovanni Battista Valeriani entitled "Collectanea Peculiarium Actionum Ab Anno 1664 sub Innocentio X Ad Annum 1779" (BAV, MS Vat. lat. 8393), a work that also dates to a time of diplomatic crisis between Naples and Rome. Other synopses of the history of the presentation can be found in G. Moroni, Dizionario di erudizioni storico-ecclesiastico, vol. 16 (Venice 1842), s.v. "chinea," and G. Lioy, "L'abolizione dell'omaggio della Chinea," Archivio storico per le provincie napoletane 7 (1882) 263-92, 497-530, 713-75.

${ }^{4}$ AN, AE B.I.963 (letter from Rome of Joseph Digne dated 30 June 1735): "La veille de S.t Pierre les ministres de la Chambre s'estant assemblés au Palais de Monte cavallo pour y recevoir les Tributs ..." “Non ostante la Sede vacante, devono compirsi alla Camera Apostolica, à tenore dell'Editto pubblicatosene . . . tutti li soliti tributi, alla riserva di quello della Chinea . . . la di cui publica funzione si differisce sino, che sia eletto il nuovo Pontefice"; AS, LM 242 (letter from Rome of Giovanni Battista Onorato Orengo, royal expeditioner of Sardinia, dated 17 June 1758). "fù un piacere l'osservar confusi, e ammutoliti alcuni di questi Politici, che dà qualche giorno francamente asserivano, ch'erasi fatta segretamente l'istanza di restringere la Funzione al semplice pagamento in Camera del solito Censo dà farsi di conformità di tanti altri, che si pagano nella soddetta Vigilia di S. Pietro"; AS, AER 1243 (letter from Rome of Giovanni Porta dated 29 May 1739). If the Holy See stood vacant on 28 June, the Chinea would be presented to the pope on 8 Sept., the vigil of the feast of the Birth of the Virgin, at S. Maria del Popolo; see, for example, Chracas, no. 1109,9 Sept. 1724,10 , and no. 6426, 16 Sept. 1758, 2-6.

${ }^{5}$ For the long-standing monopoly on the office, see $\mathbf{n}$. 343 below. "Il Sig.re Contestabile Colonna per grazia segnalata hà ricevuto dall'Imp.re un Diploma perpetuo, con cui si ordina à tutti i Governatori, Giudici, e Ministri Cesarei, à quali appartiene, che tutti gl'effetti di d.o Sig.re, esistenti ne Stati Imperiali, restino esenti da ogni dazio, ed imposizione in perpetuo"; ÖS, RK 108 (insert in a letter from Rome of Johann Bessel dated 21 Sept. 1722). "Eccellenza / In coerenza di essersi il Rè servito di prorogare à V.E. per un altro triennio l'Incarico di 
Equally remarkable is the series of 108 etchings related to the set pieces built for the Chinea, the work of numerous printmakers that collectively spans more than six decades of the eighteenth century. In addition to these visual documents, the Colonna archives contain very rich accounting records and artists' contracts for the staging of the Chinea, which establish that it usually took between fifty-five and sixty days to construct the set pieces. ${ }^{6}$ We learn that the Chinea and other ephemeral events (including musical performances) were mounted with what one scholar has termed "deficit financing," so a lack of liquid assets proved no hindrance to elaborate stagings. Readily available credit both increased the public's expectations and protected the patron against possible nondelivery of merchants' goods and artisans' services. ${ }^{7}$

Pierre-Jean Grosley, a French lawyer, epigrapher, and antiquarian who traveled through Italy in 1758, wrote that "all civic and religious ceremonies that go together with pomp and public display are called 'functions' at Rome: they supplant the spectacles for which the Roman people were once so avid." ${ }^{8}$ The tradition of bread and circus games still ran deep, sometimes in surprisingly literal ways. ${ }^{9}$ Ritual was Rome's business, and building (whether permanent or temporary) its principal industry. Urban spaces resounded with carpenters' work: sawing, planing, rasping, chiseling, gouging, and boring; the pounding together of joints; the crash of lumber as it was piled up for use, or fell from sawhorses, or as wooden structures built from it were pulled apart; curses resulting from a hammer's false blow; the shouting of orders and responses; cries from bystanders or from men working on high scaffolds that cut

Suo Amb:re Straord:o presso la Santa Sede per l'atto di presentare al S. Padre la consueta annuale Chinea; si è altresì la M.S. degnata rilevarla dal Diritto del Valimento dei Beni ch'Ella possiede in questi Regni; e ciò in considerazione delle spese che le Causa la tal funzione"; AC, II.GG.4, 1759, no. 65 (letter from Caserta of Bernardo Tanucci dated 6 Jan. 1759). Tanucci estimated the annual profit the constable derived from the tax exemption at 9,000 or 10,000 ducats; see, respectively, AGS, SE 6109 (letter from Naples of Tanucci dated 17 Sept. 1776), and ibid. (letter from Portici dated 22 Oct. 1776).

${ }^{6} \mathrm{With}$ access to other similarly rich archival materials, one could draw useful comparisons between the Chinea and other festivals of the period. See J. E. Moore, "Obsequies in Rome for Ferdinand VI of Spain, 1759," in Memory and Oblivion. Proceedings of the XXIXth International Congress of the History of Art, ed. W. Reinink and J. Stumpel (Dordrecht 1999) 307-15.

7 Paolo Negri, Roman secretary of the duke of Savoy, describing name-day festivities for Maria Luisa d'Orléans held in Rome on 18 Aug. 1688, wrote that performing musicians wore their own clothes, which "was thought to be very improper, since his Excellency should have outfitted them all in uniforms. This would not have put a strain on his pocketbook, since he was financing the whole affair on credit anyway. The next morning the following couplet [pasquinata] made the rounds . . Il signor Marchese di Coccogliudo fa tutto quello che deve $e$ deve tutto quello che fa"; quoted trans. in J. Spitzer, "The
Birth of the Orchestra in Rome-An Iconographic Study," Early Music 19 (1991) 22-23, who uses the phrase "deficit financing." For an illustration of the set piece and musicians' platforms, see M. Moli Frigola, "Fuochi, teatri e macchine spagnole a Roma nel Settecento," in Il teatro a Roma nel Settecento, vol. 1 (Rome 1989) 24445, fig. 5; for the relationship of festivals to debt, 216 17. Partial payment and extended credit ensured that "the artisan did not suddenly leave the patron in the lurch"; Pollak, 206.

${ }^{8}$ Grosley, 3:47; for Grosley, see Dictionnaire de biographie française, s.v.

${ }^{9}$ Chracas, no. 7251, 24 Dec. 1763, 12: "Per essere stato il tempo da molti, e molti giorni quasi sempre dirotto in pioggia, per il che la povera Gente di Campagna non si è potuta esercitare nelli lavori della medesima per guadagnarsi il vitto, ed essendo venuti nella Città in gran numero, per esser soccorsi, la paterna carità di Sua Bñe ha fatto loro somministrare del pane a sufficenza, per alcune mattine, al Colosseo, ove fu ordinato, che si adunassero." The following account recalls the ancient congiarium: "[p]er il medesimo festeggiamento della Coronazione della Santità Sua, fu già il Sabbato antecedente distribuita . . . la solita elemosina di un grosso [.05 scudo] per ciascheduno alli poveri, nel gran cortile di Belvedere del Palazzo Vaticano, il che fu eseguito con gran carità, e buon'ordine, ancorche vi concorressero in numero considerabile di più, e più migliaia tra homini, e donne, e fanciulli"; Chracas, no. 6558, 21 July 1759, 13-14. 


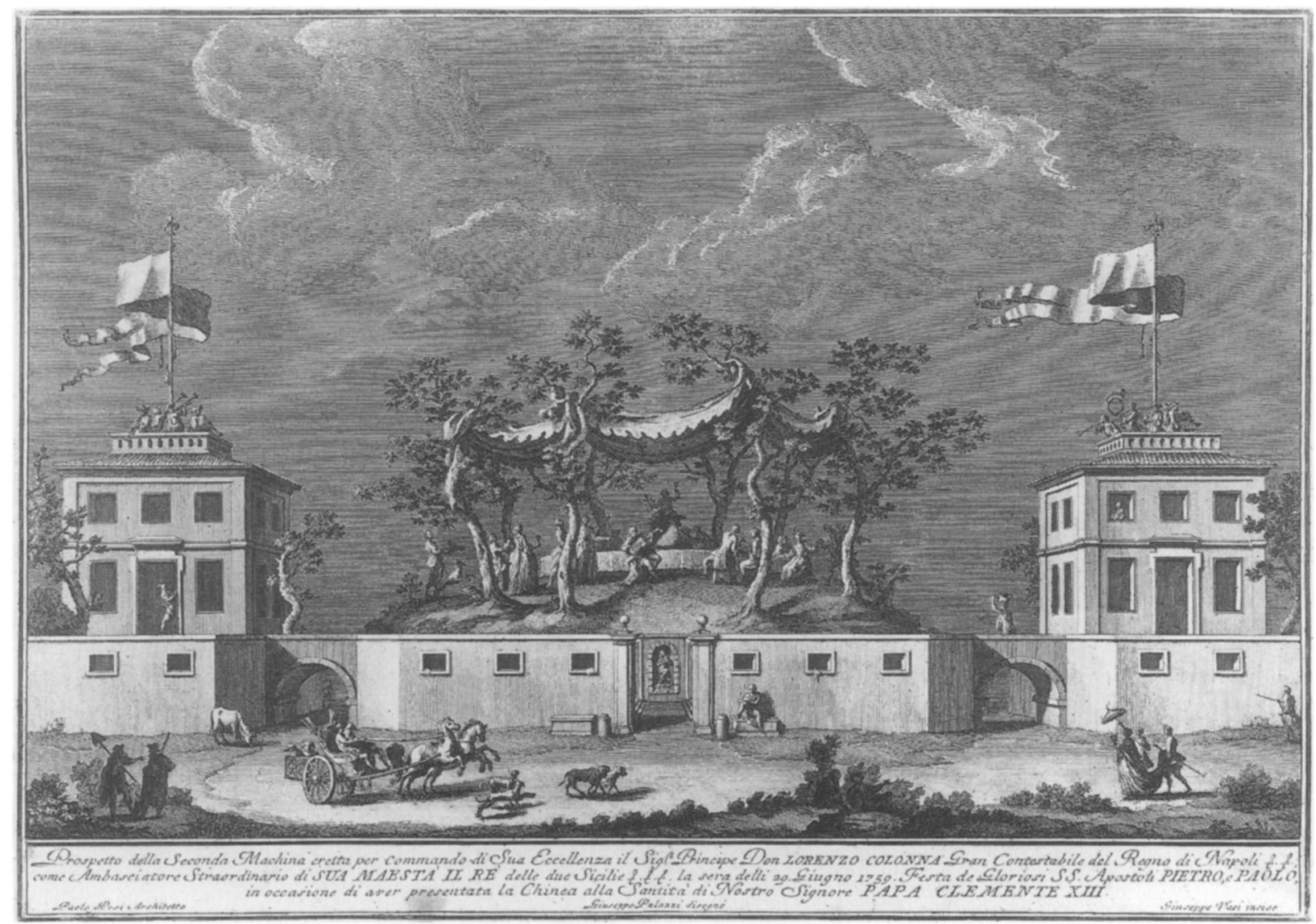

Fig. 1. Giuseppe Vasi (after Giuseppe Palazzi), first set piece for the Chinea of 1759, etching. Getty Research Institute (photo Getty Research Institute, Research Library).

through the bustle and din of streets and squares or reverberated against the vaults of a church. The commonplace that likens baroque Rome to a theater should also evoke such backstage efforts, cacophonous yet precisely synchronized, that enabled contemporaries "to see what is common executed with novelty." Imprints of the nuts-and-bolts human labor that created the Chinea structures are voluminously preserved in the Colonna archive. My aim is to reconstruct the events that led to the erection and decoration of the two set pieces for the Chinea of 1759 (figs. 1, 2). The procedures followed that year were definitively established soon after the Colonna became ambassadors extraordinary for the Habsburg monarch Charles VI in $1722 .{ }^{11}$ The year 1759 was unusual in that sometime before the morning of 28 June the

10 "la curiosità risveglia più vivamente la voglia di vedere con novità eseguito quello, che per altro è comune, cioè a dire: la funtione, di cui parlo, si fà ogn'anno: mai però si è fatta così sontuosamente"; M. A. Nobili, trans., Descrittione del corteggio, e pompa, con la quale D. Maffeo Barberini presentò la Chinea ad Alessandro VII (Rome 1663) 3.

${ }^{11}$ AS, AER 1241 (letter from Rome of Giovanni Porta dated 25 March 1738): "Per fine dicesi, che seguendo presto la recognizione si potrà anche vedere per la prossima Festa di S. Pietro la strepitosa Funzione della Chinea, e che nell'angustia del tempo, che non permetterebbe la spedizione à tale effetto di un Ambasciatore Straordinario, Sua Maestà potrebbe commetterla à questo suo Vassallo Contestabile Colonna, che hà già in ordine tutto, avendo fatta simil funzione per più anni in nome dell'Imperadore." "Non sentendosi ancora nominato dalla Maestà del Rè nostro Signore il Soggetto per la presentazione della Chinea nella prossima Vigilia di S. Pietro, ella è universale la curiosità di sapere chi 


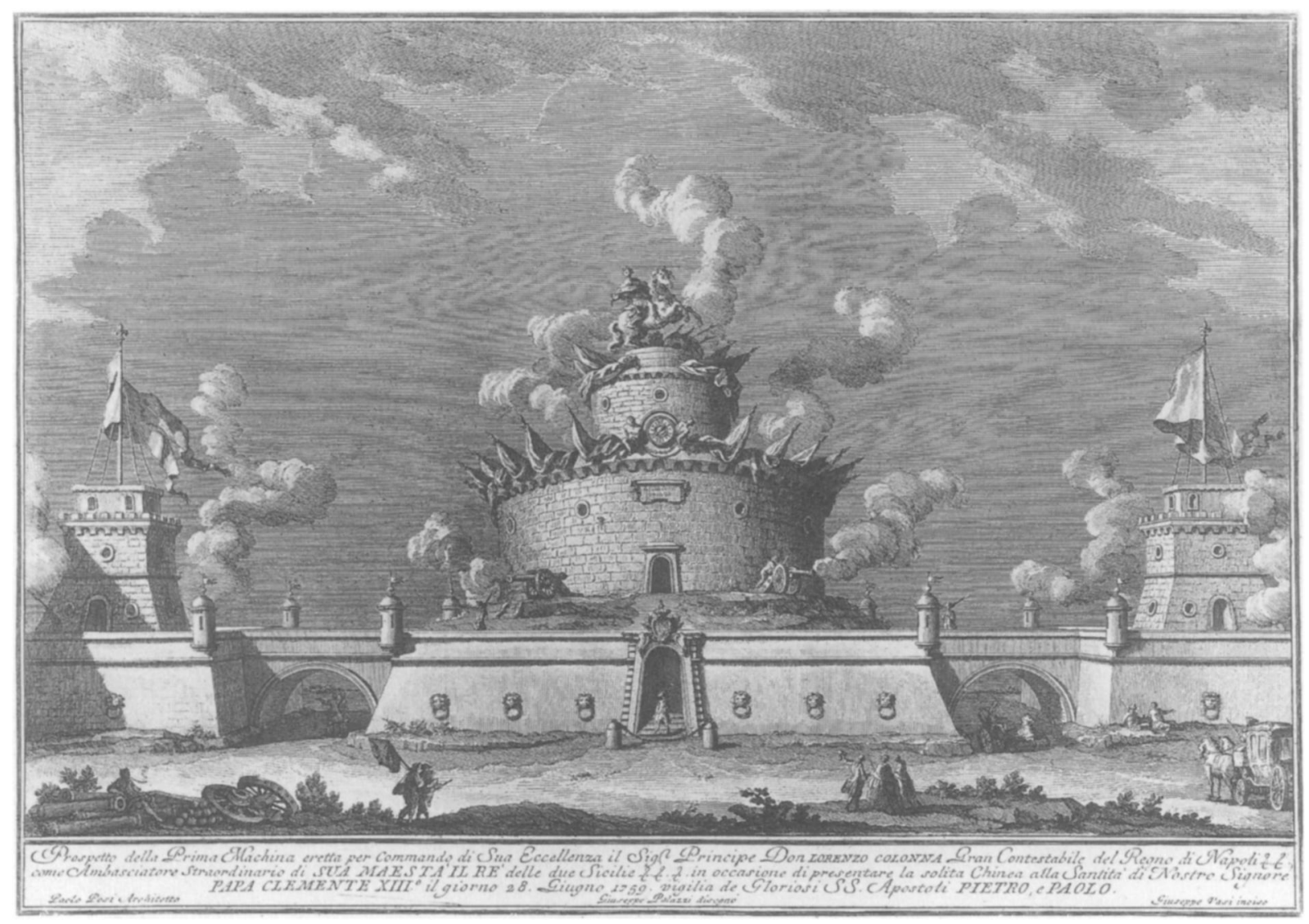

Fig. 2. Vasi (after Palazzi), second set piece for the Chinea of 1759, etching.

Getty Research Institute (photo Getty Research Institute, Research Library).

preparations were interrupted by rain. That inconvenience today makes possible a more circumstantial recounting of how set pieces were actually built and decorated. Thus the waterlogged and resuscitated structures of 1759 are of greater usefulness than others. I shall account for the transformations of the Palazzo Farnese and adjacent piazza in the sixty-odd days between 7 May and 7 July. Moneys paid and in-kind disbursements will be cited, usually in the notes.

Through the lens of the Chinea, the economics of the Roman festival industry, a topic hardly conceptualized in previous studies, can be brought into focus. ${ }^{12}$ The archives provide a means for delineating the day-to-day outlays of a noble family. Variously generated and collected, contracts, bills, receipts, petty-cash ledgers, and inventories of staples constituted

farà questa solenne Funzione, di cui tanto maggiormente si parla, quanto che dicesi, che il Contestabile Colonna si disponga à partire ogni volta per cotesta Dominante ad' effetto di prendere l'Abito di S. Gennaro dalle mani della Maestà Sua; si riflette dà tal sorta di curiosi, che attesa la brevità del tempo ei solo sarebbe in grado di compiere al decoro, e alla magnificenza della Funzione per trovarsi già proveduto di Carozze, Livree, e di ogn'altro cosa necessaria"; AS, AER 1243 (letter from Rome of Giovanni Porta dated 26 May 1739).

${ }^{12} \mathrm{~A}$ general overview of the technical aspects of building Chinea and other set pieces is in Gori Sassoli, 3438. For economic and social life, see M. Andrieux, $L a$ vie quotidienne dans la Rome pontificale au XVIIIème siècle (Paris 1962), and Gross. 
an active reference bank for the administrators of princely households, religious communities, and municipal and national governments. Such documents were needed in order to formulate, modify, or justify contemporaneous and future action. ${ }^{13}$ In accounting for eight barrels of wine given in 1759 to Giuseppe Vasi, the etcher of forty-nine prints related to Chinea set pieces including those of 1759 (figs. 1, 2), the butler Pietro della Bitta wrote that the disbursement was "not to become an example," a phrase that could indemnify the Colonna against subsequent claims. ${ }^{14}$

Phrases in the accounting records amply demonstrate that the Colonna administration followed well-established patterns when conducting its business. Such reliance on precedent had long been a sign of princely status. ${ }^{15}$ Georges Chastellain, court historian of the dukes of Burgundy, wrote that "after the deeds and exploits of war, which are claims to glory, the household is the first thing that strikes the eye, and which it is, therefore, most necessary to conduct and arrange well." ${ }^{16}$ A set of directives entitled "The orders to be infallibly observed in the household of the prince of Butera in the weekly meetings" codifies the economic structure of the Colonna household. ${ }^{17}$ The connection between Butera and Rome had been established in the early seventeenth century, when a daughter of the prince of Butera became the wife of Federico Colonna (1600-1641); from that point forward the locality numbered among the Roman prince's feudatory holdings. ${ }^{18}$ The directives transcribed below (with emphases in the original) provide the fundamental operational context for the construction of Chinea set pieces.

1 First, that on the last day of every month this document must be read by the secretary, so that there be no excuse of not knowing it.

2 That every Saturday the master of the house [Mastro di Casa], the steward [Scalco], and the accountant [compotista] must meet in the secretary's office, so that in said meeting [Congregatione] a summary of irregularities in the accounts be given [se ne dano li disordini si fanno nelli conti], the means for moving forward and remedying abuses be discussed, and the master of the house provide a summary thereof to His Excellency.

\begin{abstract}
${ }^{13}$ As in the title page of a late-sixteenth century diary, "Libro ove giornalmente si notaranno gli negocij dell'inclito Pop. Ro: . . . Nell'anno M.D.XCIIII. Per instruttione perpetua d'i futuri Magistrati"; Rome, Archivio Storico Capitolino, Camera Capitolina, Cred. IV, Tom. 104.
\end{abstract}

${ }^{14}$ AC, I.A.438/155: "e questi da non passarsi in essempio."

${ }^{15}$ At the bottom of an abriged account (ristretto) of expenses incurred at a poulterer's over the course of a calendar year is the phrase "volti che vi è il Riparto"; AC, I.A.437/132. "In avvenire non si passeranno conti se li bollettini non saranno firmati da me q.to di 7 Giug.o 1758. [signed] Pietro Battisti”; AC, I.A.421/114.

${ }^{16}$ Quoted in J. Huizinga, The Waning of the Middle Ages (Garden City, N.Y. 1954) 41. A comparison can be drawn between the Colonna household directives and those of the Willoughby family in sixteenth-century England: "The butler is also to use good discretion in serving forth of the bread and beer to the houses of office, as to the kitchen, the bakehouse, the nursery, and such like, that he, understanding the allowed number there, may so serve them, as it neither be with want nor yet with over great excess"; A. T. Friedman, House and Housebold in Elizabethan England. Wollaton Hall and the Willoughby Family (Chicago 1989) 186.

${ }^{17}$ AC, II.A.18, no. 46, "Gl'Ordini che si hanno da osservare infalibilmente nella Casa del Sig.r Principe di Butera nella Congregatione." Located $15 \mathrm{~km}$ southeast of the Sicilian city of Caltanissetta, Butera was homonymous with the highest noble title in Sicily. The title of prince of Butera was formally established in 1563, but the land and its sovereigns had also been linked to the Normans. See Enciclopedia italiana, s.v. "Butera."

${ }^{18}$ For Margherita di Francesco Branciforte, princess of Butera, see P. Litta, Famiglie celebri italiane, fasc. xxxvii (Milan 1837), pl. ix; for Colonna fiefs, see P. Colonna, ed., I Colonna dalle origini all'inizio del secolo XIX (Rome 1927) 327-28. As Federico Colonna was one of the signatories, the directives can be dated no later than 1641. 
3 That all items bought must go into the dispensing storeroom [Dispensa] with weight, number, and measure recorded, and thence must similarly leave, and this down to the last piece of fennel, and nothing must go into the kitchen, if it has not first been recorded by weight and number in the dispensing storeroom, and from said dispensing storeroom it must leave with a receipt.

4 That the said principal officers of the household see to it that the agreed prices are observed by the merchant, and that those prices being altered, they may not pass without an order from the master of the household, and there being no such order, they cannot pass.

16 The master of the house must particularly keep his eye on the wine cellar, so that the agreed amount of wine be taken out, and only the correct amount of snow [et che la neve non se ne piglia, se non il giusto].

23 That on the 30 th of every month the accounts of goods having entered the dispensing storeroom must be balanced, and on a sheet in the master ledger be entered everything that is in said storeroom, so that one knows what is there and what needs to be procured.

The injunction that these instructions be read aloud once a month attests to their perceived importance, and the hundreds of extant monthly inventories of oil, wax, sugar, bread, wine, and other staples prove that the quartermaster (dispensiero) did in fact account for what entered and left the pantry (credenza). A piece of fennel as a least-common denominator supplies an amusing image of the scrupulous attention to detail that kept the bookkeeper's office busy, for it had not only the palace in Rome to oversee but the Colonna's various fiefs. Each year that office's handiwork filled between six and ten volumes that included three types of documents: (1) the bills that merchants and artisans presented to the Colonna; (2) contracts the Colonna drew up to engage artisans' services; and (3) in-house inventories. Bills for services rendered in Rome, delivered directly, are hardly ever folded and rarely have traces of sealing wax. Others were sent via post and bear the signs that the Roman bills lack. The constable's signature at the bottom of most artisans' bills implies that he gave final approval to expenditures. Preceding his signature is a standard formula: "let our accountant credit the account of . . . for scudi ... without prejudice." According to common practice, funds were transferred from Colonna bank accounts to those of merchants and artisans. Settling a bill did not signify that the Colonna absolved anyone of subsequent financial responsibility should goods or services have proved wanting.

Over the years, a select group of men and women formed a veritable extrahousehold staff for the production of the Chinea, a particular type of commodity. Continuities of patronage and marketplace transcended the death of individuals, for affairs often remained in the hands of original agents' heirs, whether widows or children, who continued to mention their relation to the defunct in bills, thus keeping alive memories of economic ties..$^{19}$ Mention that a service was "for the Chinea" would often result in an uncut price, which underscores both the special status of the festival within the Colonna household and the importance of precedents in governing patron-client relationships..$^{20}$ This mechanism of agreement could break down when the

${ }^{19}$ For a similar phenomenon in the management of the Farnese palace, see G. Michel, 537-38. One "Cecilia Tedeschi Ved. Rel. del q.m. Franc.o Tedeschi” presented a bill for works in travertine related to the rising Trevi Fountain; see Pinto, 266. For the bill of "antonia Seghetti Vedova delle quondam' Giuseppe Alberici capo Mastro Falegniame," see n. 54 below. Seghetti was still active in February 1772, as a bill for a reception held in palazzo
Odescalchi for William Henry, duke of Gloucester, attests; see R. Valeriani, "Fasto nobiliare: Il gusto e l'etichetta," in Fagiolo, 2:132.

${ }^{20}$ At times artisans had to absorb the costs of inflation, like the silversmith Vincenzo Belli in 1755, who tried unsuccessfully to pass on, "per remisione di Argento," a surcharge of 3.45 scudi; AC, I.A.403/49. In the same year, 
same merchants and artisans provided goods and services unrelated to the Chinea, which were sometimes listed separately. These latter were subject to the same careful auditing as all others. Most bills have two sets of figures, the requested price in the right margin (coming after the description of the item), the audited price in the left. House architect Paolo Posi audited the bills of sculptors, masons, painters, festival-hangers, tinsmiths, and carpenters, both in Rome and in Colonna fiefs. He could apply with impunity his understanding of the value of goods and services and may have received a percentage of the total sum on bills he audited. ${ }^{21}$

The documents refer to distinct parts of the festival, and it has seemed best to organize the present study accordingly. The categories spring from the accounting records themselves, or rather from the clearly demarcated program of events that was implemented annually as part of the constable's ambassadorship, the parameters of which were set out in a manuscript protocol of $1769 .{ }^{22}$ The network of interlocking activities became tighter as 28 June approached, so a strictly chronological analysis would, in any case, prove unhelpful.

\section{From "Ghetto" to "Royal Palace": Transforming the Farnese Palace}

The 1769 protocol includes this sentence about the Farnese palace, where receptions for cardinals, prelates, ambassadors, and Roman nobles were held: "the warden must go outfit the royal palace" ("si ordina intanto, che il Guardarobba vada ad ammobiliare il Palazzo Reggio"). These words hardly correspond to the scale and complexity of the task at hand. As embassy and residence of the plenipotentiary of the kingdom of the Two Sicilies, real estate office, and center for the conduct of Neapolitan affairs in Rome, the Farnese palace was a primary player in the annual unfolding of the Chinea.

The constable had first to ascertain whether the palace was available for use. Giacomo Maria Sersale, duke of Cerisano, was plenipotentiary from 1750 until October 1759. In rooms adjacent to his apartment (fig. 3, V, T, U), the constable received and entertained guests on the nights of 28 and 29 June (fig. 3, W, X, Y). Members of Sersale's domestic staff divided a cash tip among themselves, for without the assistance of people who knew the building well and

the constable's Neapolitan agent, Filippo Agostino de Martinis, who procured hosiery for the household staff for the Chinea, wrote that "si averebbe avuto da alterare il prezzo da riflesso dell'argento che va carissimo," but went on to say that he was able to obtain the previous year's price; AC, I.A.403/40. In 1762, the cloth merchant Pietro Bartoli succeeded in receiving more money than usual, but only after the Colonna staff had verified his claims. After the usual prices for "tela serpe" and "barbantina bianca," he wrote, respectively, "Per Acrescimento di [baiocchi] 15 la p.za fatto in Germania dette tele dal solito prezzo 4:50," and "Per Acrescimento di [baiocchi] 50 la p.za fatto in Ulmo detta Barb.a dal solito prezzo 10-." Master of the household Angelo Orlandi wrote as follows: "Costo degl'altri anni [scudi] 162.40 Si pretende dal Bartoli in q.to anno 1762 l'accrescimento di [scudi] $4.50 \mathrm{dal}$ med.o pagato sopra le pezze $30=$ tela serpe e [scudi] 10 per l'accrescim.to pagato sopra le pezze $20=$ Barbantina, il quale si verifica, secondo l'informazione presa dagli altri Mercanti, li quali asseriscono essere tutte le merci forastiere generalm.te accresciute anche in maggior Somma atteso le presenti guerre, onde si ponga à parte [scudi] 14.50"; AC, I.A.459/22.

\footnotetext{
${ }^{21}$ In the seventeenth century it was customary for architects to receive 2 percent of the total audited cost of a building project or the total final cost of any other intervention they oversaw in a princely household. Naturally, disputes between the parties often occurred; Pollak 206, 209. For Posi's activity as an auditor, see In urbe architectus: Modelli, disegni, misure. La professione dell'architetto a Roma 1680-1750, ed. B. Contardi and G. Curcio (Rome 1991) 423.
}

\footnotetext{
22 "Direzzione istruttiva per la funzione della Chinea . . . l'anno 1769," by Alessandro Saracinelli; AC, II.GG.110. For a study of this protocol, see J. E. Moore, "come si costuma per tal funzione: Protocols for the Presentation of the Chinea," in Barocke Inszenierungen, ed. J. Imorde, F. Neumeyer, and T. Weddigen (Emsdetten and Zurich 1999) 236-53.
} 
could resolve logistical problems, the ability of the constable's staff to work efficiently would have been significantly diminished. Payments-in-kind and a cash tip were disbursed to the domestic staff and stable hands of Neapolitan agent Filippo Ascolese, who lived in the Farnesina from 1751 to 1761 . His factotum (facchino) and basket-carrying porter (sportarolo) also obtained in-kind payments. ${ }^{23}$ The "Royal Farnese Household" ("Real Azienda Farnesiana") oversaw a number of properties in Rome and undertook needed repairs in the piazza Farnese and along the two streets that flank the palace, the modern via del Mascherone and the via de' Farnesi; in May 1759, Ascolese requested that funds be budgeted for such repairs. ${ }^{24}$ Others, too, helped the constable and his staff put the embassy in order. A servant and a coachman of Gaetano Centomani, royal auditor and secretary to Sersale, received in-kind payments. ${ }^{25}$ So did the servant of Francesco Dionigi, who served as master of the household and secretary, having inherited these positions from his father, Vincenzo. For nearly a century, the Dionigi family lived in the small but convenient house next to the church of S. Maria dell'Orazione e della Morte, which was connected to the Farnese palace by a bridge over the via Giulia. ${ }^{26}$

In 1759,150 persons lived in the Farnese palace, among whom was the printmaker Giuseppe Vasi. Born in the Sicilian town of Corleone, Vasi had come to Rome as early as 1736. In 1747 he went to Naples, where he etched several plates in a festival book commemorating the birth of Filippo, the first son of Maria Amalia and Charles VII (later Charles III of Spain). ${ }^{27}$ Upon his return to Rome, this service, coupled with his status as a royal vassal, won him the offices of warden and royal printmaker and the privilege of a residence in the royal palace. In June 1759, Vasi lived on the second floor, directly above Cerisano's apartment. Later that year, the new plenipotentiary, Domenico Cardinal Orsini, duke of Gravina, tried in vain to expel Vasi, the artist having expanded his operations well beyond the spaces originally allotted to him. ${ }^{28}$ Despite this challenge, from 1760 to his death in 1782, Vasi lived and worked in the ground-floor apartment in the west corner of the palace, the appartamento dell'atlante (fig. $4, \mathrm{~L}, \mathrm{~K}, \mathrm{I}){ }^{29}$ To his busy studio, according to custom, came subscribers and,

${ }_{23}$ "Alla Sala del S:re Marchese Ascolese," 5 jugs; "Alla Stalla di d.o," 4 jugs; "Al Facchino di d.o," 2 jugs. "Alla Sala del Sig.re March.e Ascolese," 10 loaves; "Alla Stalla del sud.o," 10 loaves; "Allo Sportarolo del Sig.re March.e Ascolese," 4 loaves. "Alla famiglia del S:re Co: Ascolesi per mancia [scudi] 2:10"; AC, I.A.443/152. The responsibilities of the factotum are spelled out: "Si è sempre tenuto un Facchino, che si prende dal ceto di quelli, che fanno tal professione in Roma; Hà egli la faticosa incombenza di tener politi i Cortili, le Scale, e le Loggie di questo vasto Palazzo, siccome l'Appartamento grande, che conviene di quando in quando ripulire, abbenche sia affatto spogliato di Mobili; Quasi giornalmente carreggia il Carbone, la Legna, e l'acqua, che abbisogna alla Cucina del Ministro; Per queste, e per altre continue fatighe, egli hà la provisione di quattro scudi il Mese, $\mathrm{e}$ una Livrea propria della sua professione, che si rinuova, quando si rinuovano le altre de Servidori, e Cocchieri"; AS, AER 1242 (letter from Rome of Giovanni Porta dated 22 July 1738).

${ }^{24}$ See G. Michel, 537.

25 “D:o [servitore] del S:re Uditore Reggio," 2 jugs;
"Cochiere del Sig.re Uditore Reggio per dui Sere," 4 loaves. For Centomani, see G. Michel, passim.

26 "d:o [servitore] del Seg:rio Reggio," 2 jugs; "Servitore del Sig.re Segretario Reggio per dui Sere," 4 loaves. For the Dionigi family, see G. Michel, esp. 513.

${ }^{27}$ For the plates, see L. Scalabroni, Giuseppe Vasi (17101782) (Rome 1981). The date of the commemorative publication (Naples 1747), and the date of Filippo's birth (13 June 1747, for which see H. Acton, The Bourbons of Naples [London 1959] 67), correct O. Michel, 598 , who writes that Vasi went to Naples "à partir de 1749."

${ }^{28}$ See AS, AER 1079, with letters of Vasi dated 10, 16, and 28 Nov. 1759. In the same volume there is an undated description of the second floor where Vasi lived and maintained his studio. Orsini tried to restrict the space, allotted to the Neapolitan consul Innocenzo Pancieri; ibid. (letter dated 25 Dec. 1759).

${ }^{29}$ Strazzullo, 3:204 (letter from Caserta dated 14 April 1765): "Il Vasi abita nel cortile di Farnese, a mano dritta 
Fig. 3. Rome, Palazzo Farnese; plan of first floor; from [École Française de Rome], Le Palais Farnèse, 2:405.

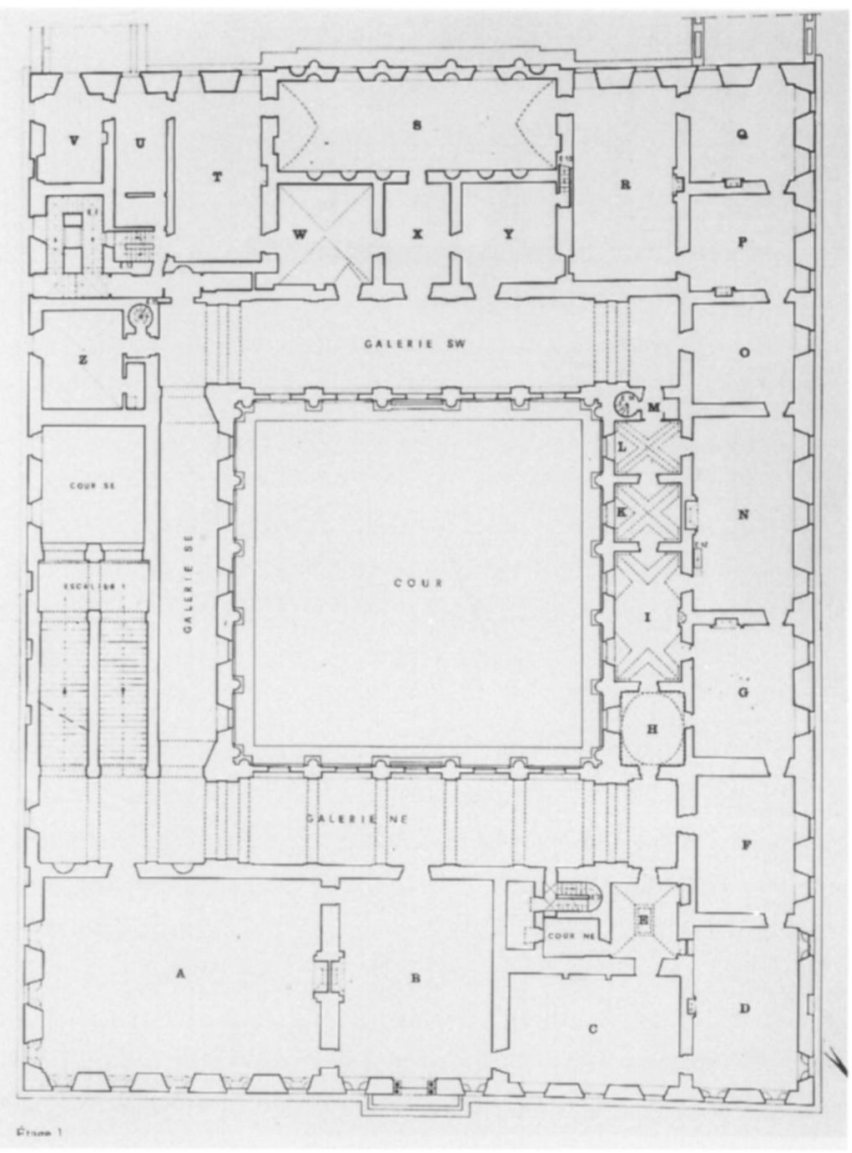

in Vasi's own words, "every class of persons" to fetch prepaid volumes of the Delle magnificenze di Roma antica e moderna, or to acquire impressions of individual prints on the spot. ${ }^{30}$

According to Cerisano, Vasi was "a most honest man, although Sicilian." 31 The office of royal printmaker doubtless helped him secure a long and profitable monopoly on the production of Chinea-related etchings. Yet it was not primarily about residents like Vasi that Cerisano complained in a letter to Naples dated 10 July 1750 . Members of the ambassador's suite were accommodated with considerable inconvenience in the palace; even Centomani was forced to live some distance away. Cerisano explained that initially he had had to establish himself in Ascolese's apartment, which he found too small for his needs. Ascolese went to live in the Farnesina the very next year. The dearth of space could be traced to people who, although unconnected to Naples, had managed to gain lodging through recommendation.

nell'entrare in faccia, dove sta l'Ercole, nel Cantone del Portico verso il Vicolo della Morte."

${ }^{30}$ AS, AER 1079 (letter dated 16 Nov. 1759): "Imperciocche è impossibile ritirarmi nelle due stanze del Cornicione, non solo per essere incapaci ad abitarci una famiglia di nove persone, ma perche, molto meno adattati al mio mestiere, concorrendo da me ogni rango di persone." "Si è veduto nei giorni passati, affisso nei soliti luoghi, il Frontespizio del settimo libro delle magnificenze di Roma . . . Si avvisano perciò i Signori Associati, che mandino a prendere il prescritto loro esemplare al Palazzo Farnese, ove [il Vasi] abita al secondo appartamento"; Chracas, no. 6189, 12 March 1757, 11.

31 "Egli è uomo onestissimo, ancorché Siciliano," quoted in O. Michel, 600. The foregoing account of Vasi's sojourn in the Farnese palace summarizes the findings of O. Michel, esp. 597-602. 


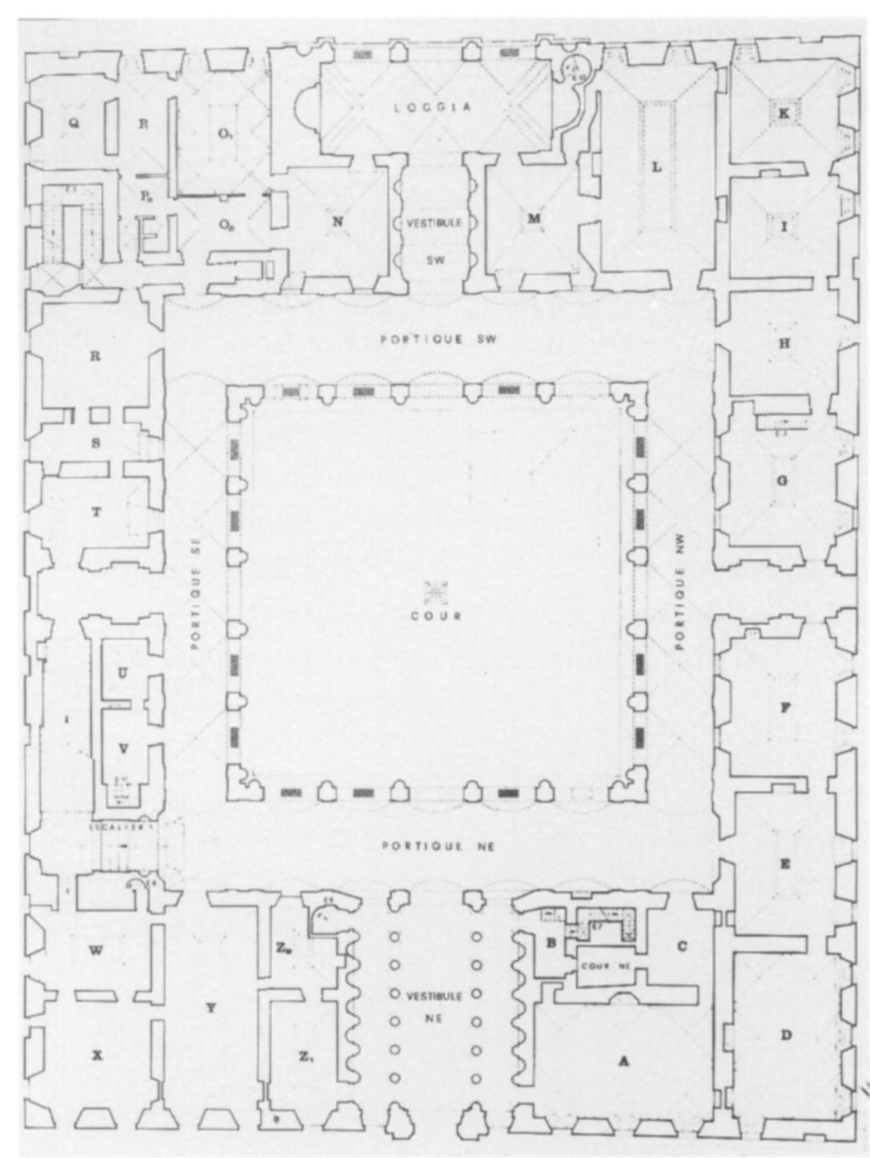

Fig. 4. Rome, Palazzo Farnese; plan of ground floor; from [École Française de Rome], Le Palais Farnèse, 2:403.

Cerisano claims that the palace, as a result, was "so full, up to the lodgings in the attic, with people of mean condition, to have merited in this city the ignominious name of 'Ghetto of the Farnese,' according to the common opinion of all who know the actual conditions." ${ }^{2}$ The representational character of the palace was compromised by the motley crew it housed, but Cerisano was determined to make the royal embassy befit the status of his monarch.

From 1738 until 1775, Charles VII and his successor, Ferdinand IV, required that Chinea receptions take place in the royal palace, and in 1738 Fabrizio Colonna's staff (and once even the constable himself) paid special visits to ascertain what was needed. ${ }^{33}$ This arrangement was

${ }^{32}$ For an excerpt of this letter from Rome dated 10 July 1750 , see S. Sersale, "Un diplomatico enciclopedico alla corte di Roma," L'Urbe 7.3 (1942) 13-21. Housing problems were not unique to those who administered the Farnese palace: "Sono cosi pieni tutti i Palazzi di S.A.R., che io mi trovo agitatissimo per assegnare un Quartiere à proposito al . . . Cav.re Conte Ferrante Capponi, e vedendo che S.A.R. vuole che in tutti i modi il detto Cav.re goda un'tal commodo, andarò pensando come posso fare per eseguire i supremi comandi della Real A.S., mà dubbito che non $\mathrm{mi}$ riescirà se io non privo $\mathrm{di}$ Quartiere qualcuno di quelli che li godono, con riceverlo in questo mentre, e per il breve tempo che il detto Cavaliere si tratterrà in Roma nel mio proprio Quartiere;
In somma vedrò qual strada posso tenere perche S.A.R. resti ubbidita, e l'istesso Cav.re ben servito. In oltre supplico VS. Illma à significarmi se debbo assegnare al detto Cav.re il Quartiere nudo, opure coi mobili, nel qual caso dovendosi necessariamente pigliare i mobili à nolo, la prego à scrivermene con lettera a'parte, acciò possa metterla nella sud.a filza"; AS, MP 3447 (letter from Rome of Antonio Paluzzi dated 17 Jan. 1722).

${ }^{33}$ AS, AER 1241 (letter from Rome of Giovanni Porta dated 16 May 1738): "Il Sig.re Contestabile Colonna fù ier'l'altro à visitare questo Real Palazzo osservando gl'Appartamenti, che dovranno ammobigliarsi, ed'insieme i commodi per accompagnare, e servire i Cardinali, 
extremely inconvenient for the constable Colonna and his household, who, not finding there everything that was needed, had to carry what was wanting from the family palace in the piazza SS. Apostoli, which from 1722 to 1733, when the Austrian Habsburgs ruled Naples and Sicily, had been the site of the receptions, set pieces, and fireworks. "For the usual efforts on the occasion of the transport of various items" in 1759, "Martino Rosati, porter, and companions" divided 10 scudi among themselves, while an unnamed porter received a cash payment for carrying two trunks. ${ }^{34}$ The porters made use of a wheeled trolley (strascino), but nothing could reduce the number of trips or alleviate the burdens they bore..$^{35}$ In 1759 , an unnamed house sculptor received in-kind payments for unspecified services, yet documents from other years name the objects transported over Rome's alternately unpaved and cobbled streets and indicate the tasks this sculptor himself or a counterpart performed on a regular basis. ${ }^{36}$ In 1755 the stonecutter Giacomo Baldi scraped clean of accumulated wax, patched, and polished with marble dust three tables (tavolini) of semiprecious stones "that [were] going to be carried to the Farnese palace"; Posi audited his bill with deep cuts. ${ }^{37}$

Apparently Fabrizio Colonna had learned to resign himself to such inconveniences. In 1757, one year after his first presentation of the Chinea, Lorenzo Colonna wrote to Naples to complain. Alleging that the interior of the Farnese palace was unsuitable, he felt that using his own palace for the receptions would better serve the king's interests and increase the splendor of the event. Patterns of protocol had already established that the plenipotentiary ambassador give over his apartment to the constable, but the spaces within that apartment were limited in their dimensions. Colonna cited the reluctance of members of the Neapolitan embassy staff to

che nelle due sue consecutive della Vigilia, e Festa di S. Pietro verranno à veder ardere le Machine de Fuochi, che saranno sulla Piazza avanti il medesimo Palazzo." "Anche oggi il suo Architetto è stato à riconoscere questo Real Palazzo per determinare la situazione propria delle Fontane di Vino, e per stabilire i commodi necessarij à i Pittori, e agl'altri Operarij, che dovranno costruire le due Machine di Fuochi Artificiati destinate ad'ardere in mezzo la Piazza frà le due maestose Fontane principal ornamento di essa Piazza"; AS, AER 1241 (letter from Rome of Giovanni Porta dated 23 May 1738). "Anche questa mattina i Ministri del Sig.re Contestabile Colonna sono venuti à riconoscere gl'Appartamenti, che si risarciscono, e si ripuliscono per la Funzione della Chinea; si è dato tutto il commodo, che si è potuto, e dentro, e fuori del Palazzo à i Pittori, Falegnami, ed'altri Operarij, che già lavorano dietro le due Machine di fuoco"; AS, AER 1241 (letter from Rome of Giovanni Porta dated 30 May 1738). In 1738, Colonna was permitted to begin the cavalcade from his own palace; see AS, AER 1241 (letter from Rome of Giovanni Porta dated 2 May 1738). Looking forward to the possible retraction of that permission, Porta thought it necessary "sollecitamente imbiancare le Loggie, e le scale di questo medesimo Real Palazzo, come certamente ve ne è il bisogno, caso che si risolvesse, che dà questa Reale Abitazione escisse l'Ambasciatore Straordinario il giorno, in cui si farà la Funzione della Chinea"; AS, AER 1241 (letter from Rome of Giovanni Porta dated 6 May 1738).

${ }^{34}$ AC, I.A.443/152: “A Martino Rosati facchino, e
Compa.ni per Le Solite fatiche In Occasione del Trasporto delle Robbe al Palazzo Farnese [scudi] 10." "Lista di Spese fatte da Gaetano Benaglia in Servizio della Chinea li 28 Giugno 1759 . . . [p]er due Viaggi di un Facchino per li due Baulli in Palazzo Farnese [scudo] :30"; AC, I.A.444/21. A payment from 1755 specifies the porters' efforts: “Io Sottos: to hò ricevuto dal S:re Fran:co Andreini ... Scudi Dieci . . per recogniz:e solita, che gli fà dare ogn'anno, in occasione del trasporto di Mobili, ed altro dal Palazzo a S:S: Apostoli, al Palazzo Farnese, in occas:e della funz:e della Chinea . . . [signed] Antonio Volena"; AC, I.A.401/151.

${ }^{35}$ For the varnishing of old and new parts of the strascino in 1754, see AC, I.A.393/125 (bill of the varnisher Giuseppe Tudini). From the same year are two related payments: "S.re Pietro darete Boccali Sedici Vino a Michele Verini per esser andato con Lo Strascino ha [sic] trasportare Le Robbe dell'Achinea al Palazzo Farnese"; AC, I.A.394/200; "S.re Ludovisi darete Pag.e Ventiquattro a Michele Verini per Essere andato con Lo Strascino à Trasportare le Robbe dell'Achinea al Palazzo"; AC, I.A.394/202.

36 "Allo Scarpellino di Casa," 4 jugs; "Allo Scarpellino di Casa," 8 loaves.

37 "Conto di Lavori fatti a Uso di Scarpellino . . . da Me Mas:o Giacomo Baldi”; AC, I.A.404/28. Alabaster and African marble were among the precious stones used. 
lend a hand, singling out Cerisano for particular reproach. Damages were incurred either in transporting goods from one place to another or during the receptions themselves. ${ }^{38}$

In 1758, royal architect Ferdinando Fuga transmitted the constable's request for storage space within the Farnese palace for furniture that had otherwise to be carried from the piazza SS. Apostoli. The wardrobe was originally proposed, but that idea was rejected by the Neapolitan authorities on 16 September 1758, just eight days after the presentation of the Chinea. ${ }^{39}$ By 18 November, Neapolitan secretary of state Bernardo Tanucci, speaking for his sovereign, had come to feel differently. In a copy of a letter to Cerisano, Tanucci, noting the inconvenience suffered by the constable's staff in transporting furniture, wrote that the king had "graciously resolved" to grant the constable's request. Described as "completely empty," certain rooms on the main floor "serve[d] for the said function [of the Chinea]." ${ }^{40}$ They were the salotto dipinto and the first anteroom (fig. 3, B and C respectively). Through the central window of the salotto dipinto, guests could climb out to the viewing balcony erected for watching the fireworks. Nothing could speak more directly to the fundamental changes in Roman protocol than the disuse into which these richly decorated and capacious rooms had fallen between the time the palace was built and decorated in the sixteenth century and the middle of the eighteenth century. Inventories record that the rooms were without furniture even in the seventeenth century. ${ }^{41}$

The constable was required to keep these rooms "locked up," including the "first anteroom, contiguous and painted." In future years, the rooms were not to be opened at all until a few days before the function, in order to "outfit the apartment." With this proviso, it was believed, the possibility of damage to the paintings would be avoided. "To which effect," Tanucci concluded, the painted anteroom was not to be outfitted at all, "the painting being ornament enough." Apart from the determination to preserve paintings in rooms that were rarely if ever used, a desire to avoid expensive repairs and restorations to the walls and floors lay behind Tanucci's decision. ${ }^{42}$ His precaution points to the damage created by putting up and taking down wall hangings, lighting fixtures, baldachins, and other forms of temporary decoration, for which ladders, pins, nails, hammers, and pliers were required. ${ }^{43}$

${ }^{38}$ For example, in 1755: "Conto, e Misura dell'infraschritti Lavori di rapprezzi di Legniami è Simili fatti ... di Giuseppe Alberici ... A di 3 Luglio [1755] Nel Cortile delli Pavoni ... Per aver ricomodato un'bufetto che ano riportato rotto da piaza fernese alli piedi fatoci di nuovo li sui pezzi di Alb:io ... Lav: pti: smusiati a torno ... rimesi in Opera li due feri rinchiodato tutto dove bisogniava [scudo] :13"; AC, I.A.404/59.

${ }^{39}$ The foregoing account summarizes the findings of $M$. Boiteux, "Les fêtes publiques dans l'environnement du palais," in [École Française de Rome], Le Palais Farnèse, vol. 1.2 (Rome 1981) esp. 644-45. For Fuga's interventions, see G. Michel, 557.

${ }^{40}$ AC, II.GG.4, 1758, no. 63. In 1722, an English traveler wrote, "' $[t]$ is a thousand pities that so noble a Palace as this is, should be left uninhabited, and in a manner desolate"; E. Wright, Some Observations Made in Travelling through France, Italy, Ec. In the Years 1720, 1721, and 1722 (London 1730) 287. The main apartment of the palace was still empty in 1738; see n. 23 above.
${ }^{41}$ See B. Jestaz, "Le décor mobilier, la sculpture moderne, et les objets d'art," in Le Palais Farnèse (as n. 39) 1.2:387408 , who does not discuss the rooms used for Chinea receptions.

${ }^{42}$ AS, AER 1172 (letter from Rome of Innocenzo Panieri, consul of the Two Sicilies, dated 2 June 1758): "nel tempo stesso le suggerirò anche li siti proprij, ove potran travagliare, ad'effetto di garantire non solam.te le Pitture di d.to Appartam.to, mà li Pavimenti stessi, che per $\mathrm{i}$ gravi pesi, che sostengono in tale occasione, ponno cedere in qualche parte, ò rovinare, e causarne poscia un notabile Dispendio à qsta R.l Azienda per ristorarli; tutto questo mi viene anche assicurato dallo stesso Capo Mro Muratore."

${ }^{43}$ AS, AER 1172 (letter from Rome of Pancieri dated 19 May 1758): "Si darà principio, per qnto sento, à travagliare in qsto Palazzo Farnese intorno le macchine dè fuochi per la Chinea, secondo lo stile, affine d'aver pronto tutto il lavoro per l'elezione del nuovo Pontefice; e siccome hò presenti le premure di Vostra Eccellenza 
When Orsini became plenipotentiary late in 1759 , the situation changed. ${ }^{44}$ Establishing patterns that were taken for granted in the 1769 protocol, the cardinal minister put his apartment at the disposition of the constable. Members of the latter's retinue had dressed and undressed in adjacent rooms, but his chamberlain soon saw that separate rooms were necessary to avoid awkward situations. Orsini set aside three spaces within the palace to be used for Chinearelated-activities: an unspecified room on the main floor for storing candles, the kitchen on the ground floor for the preparation of refreshments (fig. 4, R), and another unspecified room for the temporary storage of plate. Spaces in an old hayloft were given over to the workers who constructed the set pieces, while a former ball court was used to store those parts of the wooden armatures that could be salvaged after the fireworks displays. Although in 1741 one of the fountains for dispensing wine to the public had been kept in a ground-floor room of the embassy, evidence suggests that the usual storage space was in the Colonna palace, in a loft above stockpiled wood recycled from Chinea set pieces; thus it fell to the constable's staff to extract these bulky objects from storage and to transport them to the tinsmith for necessary repairs, which may normally have included varnishing. ${ }^{45}$ The cardinal refused to cede to his temporary guest in one instance. He insisted that his own coat of arms remain in place in the audience room, since he preceded any ambassador in rank. ${ }^{46} \mathrm{~A}$ Spanish agent in Rome cast aspersions on this and other Orsini pretensions, wondering how the service of the king of Naples, within the confines of that monarch's palace, could take second place to a cardinal's desires. ${ }^{47}$

Two members of the domestic staff of the Neapolitan embassy were singled out for remuneration. Contemporary sources attest that people whose behavior left much to be desired habitually sought and gained entrance to Roman palaces. ${ }^{48}$ During the days of the

per l'indenizzazione delle Pitture, ed altro del nobile appartam.to di d.o Palazzo, così sarò in persona à vedere come venghino trattato dagl'indiscreti Operarj, per poterne fare à Vostra Eccellenza un'esatto ragguaglio, affinche possa poi ripararne il disordine, e pregiud.o nella miglior forma che sarà possibile." As of 2 June, work had not yet been begun; ibid. (letter dated 2 June 1758).

${ }^{44}$ For Orsini, see Recueil des instructions données aux ambassadeurs et ministres de France depuis les traités de Westphalie jusqu'à la révolution française, ed. G. Hanoteau, 20, vol. 3 (1724-91) (Paris 1913) 409, n. 5; and G. Moroni, Dizionario di erudizione storicoecclesiastico, s.v. "Orsini, Domenico." "L'Emo Sig. Card. Orsini Lunedì [19 May] della presente settimana . . . portossi per la prima volta a pernottare nel Regio Palazzo di S.M. il Rè delle due Sicilie in piazza Farnese, dove si tratterà di abitazione come Ministro Plenipotenziario della detta Corona in questa Corte"; Chracas, no. 6690, 24 May 1760, 9.

${ }^{45}$ AC, I.A.404/59: "A di 26 Giunio [1755] Per le Fontane di piaza Fernese Per esser andatti in più Volte nelle Cortile delli pavoni asistere li fachini aiutare per Calare con diligenza le fontane che staveno sopra alli Legniami è caricate sopra il caretto per tempo di due homini per fare il Sud:to Lavoro una Giornata per Ciascheduno [scudo] :60." The tinsmith Carlo Giuseppe Bassetti carried out repairs on these fountains: "A 19 d.o [June 1755]
... Per avere speso alfachino perfarle prendere nel cortile d.o de pavoni e portarle a Bottega per farli le sud.e fa.e [baiocchi] 20 e peraltri [baiocchi] 20 perfarle portare nel Palazzo fernese perfarli dare lavernicia speso del proprio in tutto [scudo] :40"; AC, I.A.404/25.

${ }^{46}$ The foregoing paragraph summarizes the findings of G. Michel, 556-57.

${ }^{47}$ AGS, SE 4966 (minute of a confidential letter from Rome of Manuel de Roda dated 31 Jan. 1760): "Ya està preparando etiquetas p.a la funcion de la Acanea q.e ha de hacer el Condestable, como Embax.or Extraord.o que lo es sprê para este acto; y la funcion y recibo se executa en el Palacio Farnese. El Duq.e de Cerisano se salia, pero S. Em.a no quiere, y quiere mantener a vista del Condestable en aq.os dias sus Armas en el guardaporton, portieras \&ce.a con otra mil impertenencias, y he visto Papel suio en que dice: que la Dignidad Cardenalicia no debe ser preferida de la de Embaxador, ni de otra alguna; come si la representacion del Rey no hiciese ventaja â otra qualq.a. Y como si la habitacion no la tuviese por esta representacion en un Palacio del Rey."

${ }^{48}$ The author of a 1696 letter to the duke of Parma wrote that people who gained access to the Farnese palace were likely to "giocare, sporcare, e far altri disordini, come di rovinare quei tesori di statue ... essendo tutti borzaroli, cappeggiatori, e più"; quoted in G. Michel, 530. 
constable's embassy, the necessity for vigilance increased, as is suggested by generous cash and in-kind payments to the concierge of the Farnese palace. ${ }^{49} \mathrm{He}$ was helped by five named individuals, each of whom was likewise paid in cash and kind. ${ }^{50} \mathrm{~A}$ basket-carrying porter also received in-kind payments. ${ }^{51}$

The work of carpenter Giuseppe Alberici was instrumental in transforming the palace. He assumed responsibility for constructing three specific items. First were three partitions "inside Palazzo Farnese." Their location is not stated in the contract of 1759, yet in 1754 locksmith Giovanni Ascenzi described two locks he had repaired "at one door of the partition under the portico in the courtyard of the Palazzo Farnese," implying that they had been fashioned at an earlier time and recently brought out of storage. ${ }^{52}$ A 1756 payment to Ascenzi proves that some partitions were used to create storage spaces for timber used by the carpenters. ${ }^{53}$ According to a 1763 bill, other partitions, sawhorses, and tables were set up in a room for preparing refreshments located across from the Farnese Bull (fig. 4, R). ${ }^{54}$ Second was the balcony over the main portal, which is shown clearly in Vasi's etching related to the first set piece for the Chinea of 1763 (fig. 5). The carpenter built a wooden supporting framework for the cloth canopy that extended across the three central bays of the palace. Above, an elaborate cartouche supported four candelabra, each of which held three tall torches. Third were "all the platforms," some of which were described as located in the entranceway, others in the ground-floor rooms. None of the representations of the procession or the set pieces depicts viewing stands or platforms near or in the entranceway. Such structures may have

${ }^{49}$ AC, I.A.443/198: “@ 24 Ag.to / Al Guarda Portone del Palazzo Farnese per mancie In Occ.ne della p.a Achinea Solita" [scudi] 4:10." "Al Guardaportone di d.o [Palazzo Farnese]," 16 jugs; "Al Guardaportone di Piazza Farnese," 12 loaves. The concierge is named in the following: "Nel fiore della sua età, e contro ogni prevenzione à riserva di una enfiaggione nel Volto non curata dal Guardaportone del R. Palazzo Farnese Vincislao Heisler, jer sera improvisam.te nel colcarsi in letto lasciò di vivere. Fui trà i primi à saperne la disgrazia, e datane parte all'Emo Ministro, si stima troppo necessario di rimpiazzare subito il posto per non lasciare il Palazzo intieram.te abbandonato"; AS, AER 1080 (letter from Rome of Ascolese dated 1 Jan. 1760).

${ }^{50}$ The names of the other concierges are Domenico Brunelli, Giovanni Pacini, Giuseppe Bernabei, Carlo Francesco, and Francesco Signorini. Each received 1.05 scudi (AC, I.A.443/152), 2 jugs, and 4 loaves.

51 "Allo sportarolo del Palaz:o Farnese," 2 jugs; "Allo Sportarolo del Palazzo Farnese," 4 loaves.

${ }^{52}$ AC, I.A.393/186: "Conto de Lavorj ad Uso di Ferraro . . = =A 22 detto [June 1754]= Accomodata Una Serr:ra addrizzati Li Scontri rinch: La Molla fattaci La ch: nova maschia Lim e post'in op:a ad una porta del tramezzo sotto al Portico nel Cortile del Palazzo Farnese [scudo] :30/:15; Ad'altra Serr:a fattaci di novo La Staffa, e piegatello alla corsarola anche la ch: nova maschia Lim: e post'in op:a ad'altra Porta nel tramezzo sud.o [scudo] :40/:25."
${ }^{53}$ AC, I.A.410/150: "Conto De Lavori fatti . . da Gio: Ascenzi Ferraro ... A di 8 d.o [May 1756] Fatto una Serratura nova da una partita con chiave maschia, e consegnata al Falegname per la porta dove tengono il Legname nel Cortile del Palazzo Farnese [scudo] :55/:35.”

${ }^{54}$ AC, I.A.465/105: "Conto de Lavori fatti ad'Uso di falegname è . . . fatti li dischritti lavori con Ordine dell'Sig:re Angielo Orlandi Mastro di Casa . . . è fatti a propri Spese è robbe è fattura di antonia Seghetti Vedova delle quondam' Giuseppe Alberici capo Mastro Falegniame . . = A di 27. Giunio [1763] = / = Alle palazzo fernese è per $=/=$ la Chinea $=/$ Per aver mandato due homini alle sud:to Luogho à fare lo stecato per dove fano Sala alle portico in in [ sic] Contro alle toro è poi essendo tornati adisfare per tempo di due homini per fare il sudetto lavore una giornata per ciascheduno con il Costo di [baiocchi] 15 di Chiodi [scudi] 2:15/_:75; Per aver fatto di nuovo per il dietro schritto Luogho un'cavaletto è serveno per le tavole delli rifreschi fatti, rustichi di filanie di castania li quatro piedi incastrati à coda di rondina con il coperchio, è fattoci di nuovo due braghette è sono Larghe il tutto Chiodato Long:e p:i 4 1/2 alto p:i 4 [scudo] -65; Per aver fatto di nuovo n.o 11 altri cavaletti simile alli sudetti [scudi] 7:15/4:20; Per essere andati in due homini à mettere le tavole delli rifreschi con li detti cavaletti è dove adetto il Credenziere è richiodate le traverse alle dette tavole con quantita di chiodi è anche le tavole sopra li cavaletti [scudo] — 75/ - :50; Per aver fatto di nuovo una tavola per li sudetti rifreschi fatta di tavole di Albuccio . . . [scudi] 3:30/ 2:325." 


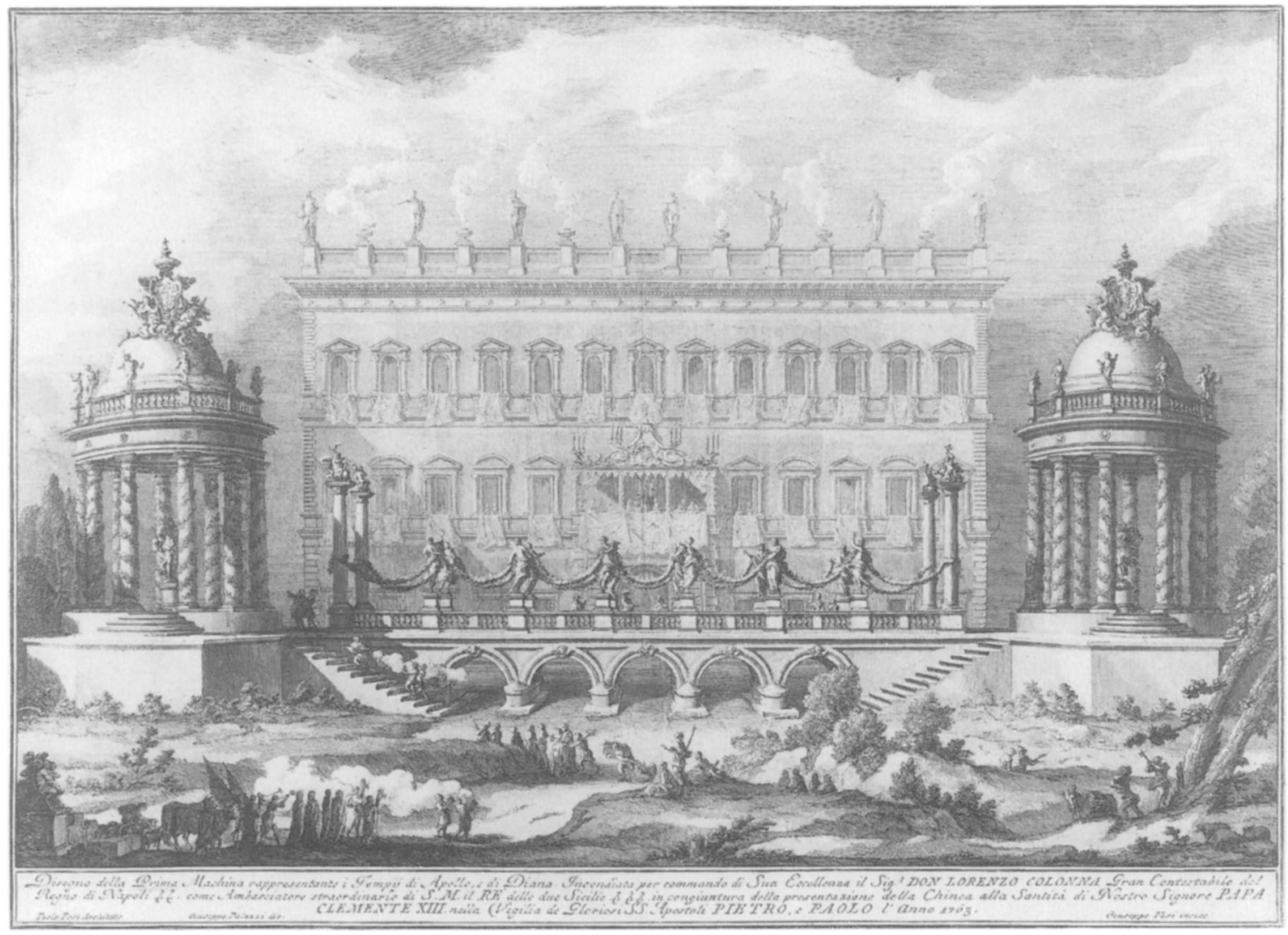

Fig. 5. Vasi (after Palazzi), first set piece for the Chinea of 1763, etching. Getty Research Institute (photo Getty Research Institute, Research Library).

served as seating for the servants and coachmen of guests or for members of the constable's staff. 55 Vasi's imaginative rendering of the cavalcade that formed part of Lorenzo Colonna's first presentation of the Chinea in 1756 depicts groups of people in the ground-floor windows of the Farnese palace (fig. 6). As these windows were set high above the level of the floor, viewing stands were indispensable.

Some platforms served the needs of musicians, even though such use is not specified in the contract of $1759 .{ }^{56}$ An etching related to another eighteenth-century Roman festival allows us to visualize similar platforms. To celebrate the marriage of Louis XV and Maria Leszczynska, a musicians' gallery was erected in September 1725 at the Palazzo Altemps (fig. 7). Built against one short side of the rectangular courtyard, the lower level of the stand picks up elements of the ephemeral decoration, which consists of pilasters covered with panels of patterned cloth (or painted decoration that imitates cloth). These same pilasters are outfitted

5s Cf. a payment from 1761: "E per avere apparato 4: palchetti d'arazzi, cioè due apparati dentro per li Sig:ri Ministri, è due fuori per li Sonatori, et apparato avanti il tavolato nel loggione dove facevano li rinfreschi con bollette tirati, et appuntati per tutto [scudi] 2:"; AC, I.A.453/104.

${ }^{56}$ Musicians once sat in the structure: "Per le suddette feste publiche ... eranvi . . . varj concerti di strumenti $\mathrm{da}$ arco, e da fiato, in due orcheste erette sulle machine, che davano piacevole compimento alla comune allegrìa"; Chracas, no. 6864, 4 July 1761,15 . This fact can be inferred neither from Posi's 1761 contract (AC, I.A.453/9), nor from the etching related to the second set piece. 


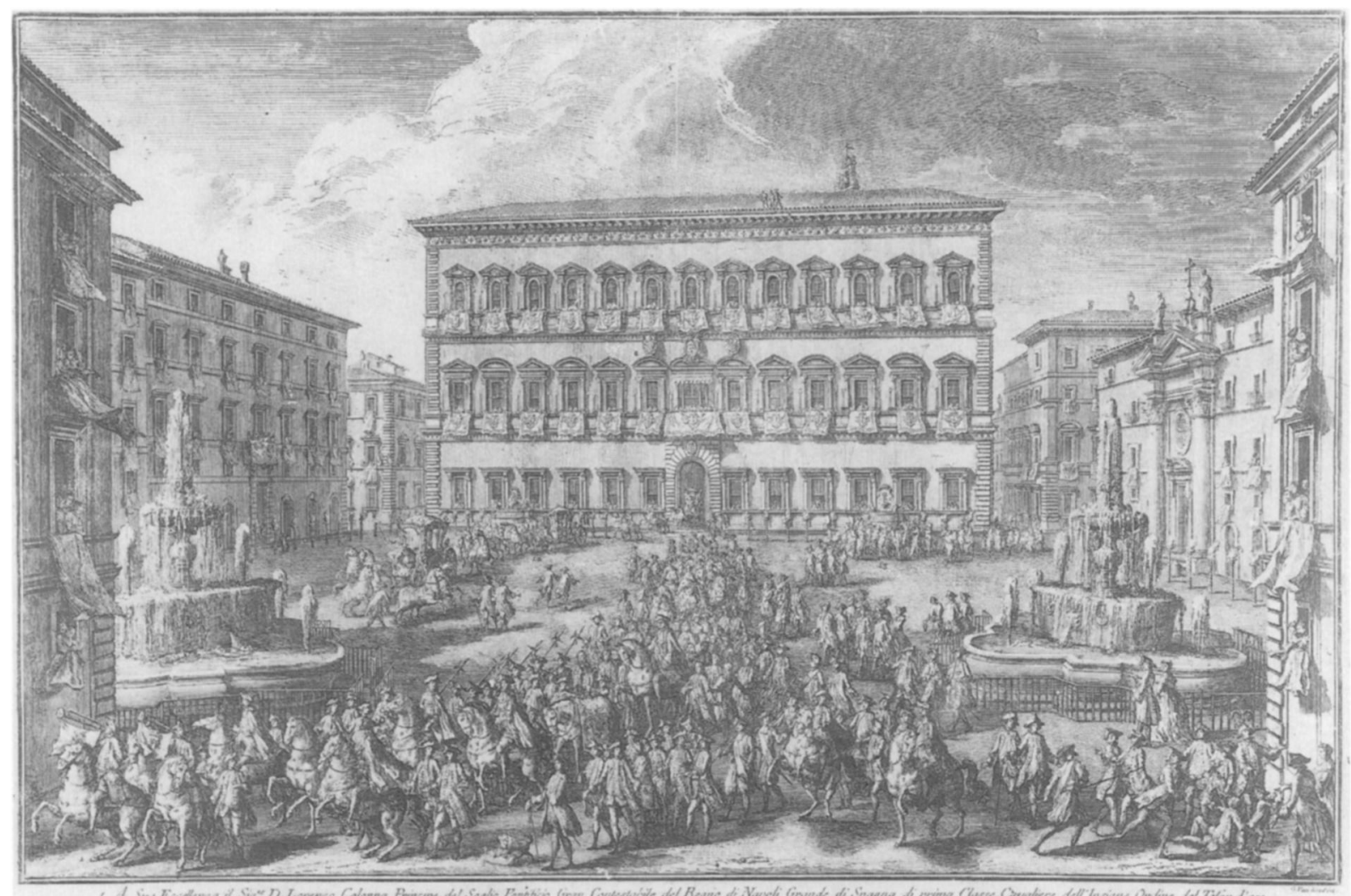

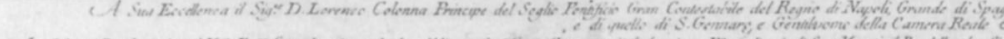

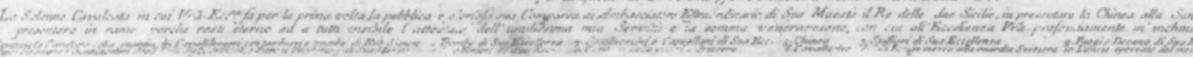

Fig. 6. Vasi, cavalcade for the first presentation of the Chinea by Lorenzo Colonna, 1756, etching. Getty Research Institute (photo Getty Research Institute, Research Library).

with candelabra set against coats of arms and adorned with fleurs-de-lis. Above, in the musicians' gallery proper, the performers are segregated according to instrument in banked rows that facilitated the diffusion of sound. Large escutcheons cap the verticals established by the pilasters below and support candelabra that would have cast light on the musicians' scores. Chandeliers hung from a gallery running at the level of the second cornice would have provided additional light. In 1759 , for the Chinea, Alberici's contract explicitly required him to build all platforms "according to custom," a phrase that takes for granted his long-standing connection to the Chinea. The newspaper account of the same year confirms that music, in the form of "diverse concerts of wind instruments, . . . gave pleasant entertainment to the multitude of people who came to listen." 57

I translate the Italian festaroli as "festival-hangers." Numerous contemporary accounts describe the metamorphic effect of their handiwork. For example, in 1757 the atrium of the Palazzo Massimo alle Colonne was transformed into "a well-constructed and designed [architettata] chapel" to celebrate a feast connected with the Virgin. ${ }^{58}$ Gold-trimmed hangings

${ }^{57}$ Chracas, no. 6552, 7 July 1759, 11: “diversi concerti di

${ }^{58}$ Chracas, no. 6255,13 Aug. $1757,6$. strumenti di fiato, che davano piacevole trattenimento alla moltitudine del Popolo concorsovi." 


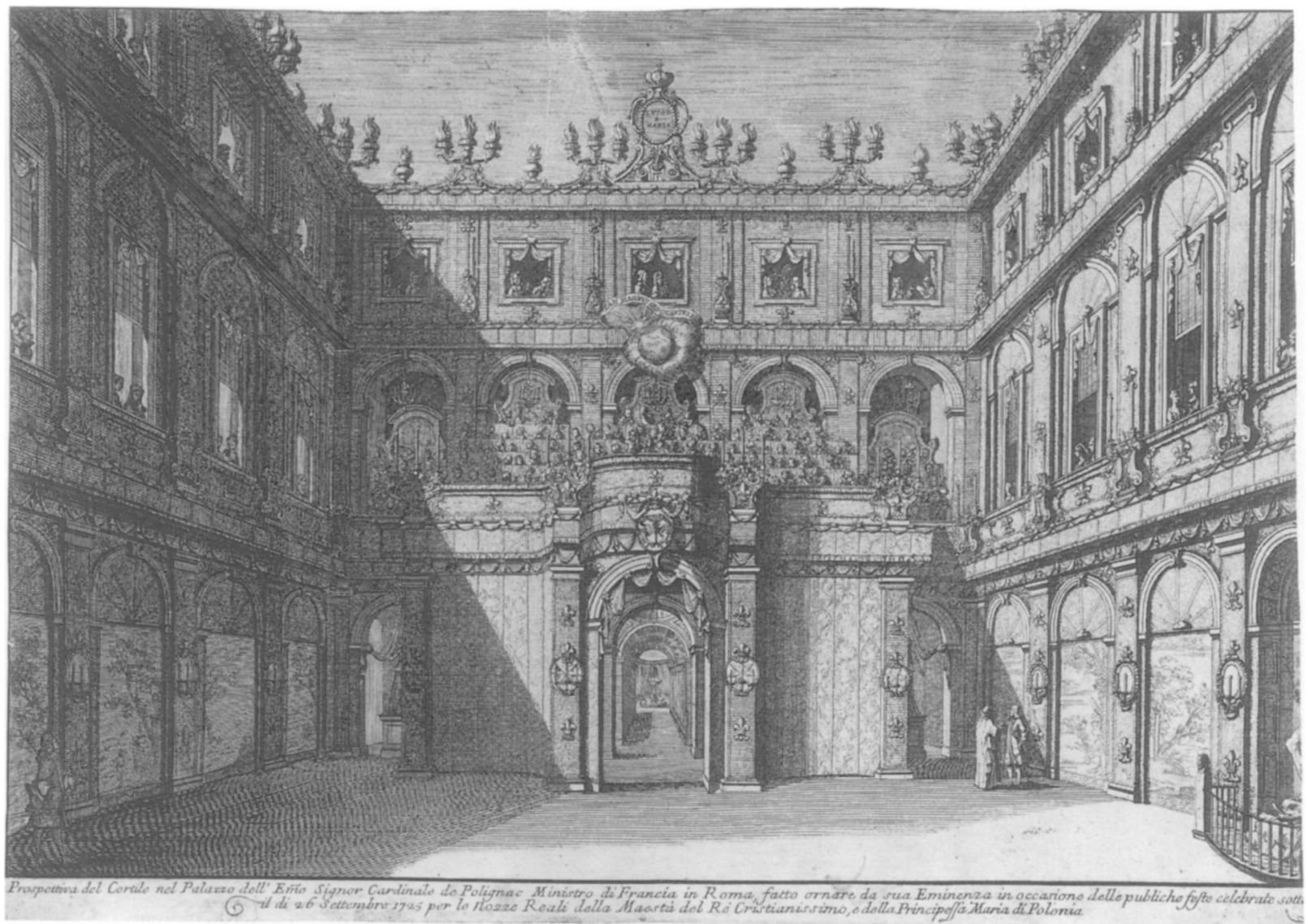

Fig. 7. Rome, Palazzo Altemps, elevation of temporary music stand for marriage of Louis XV and Maria Leszczynska, 1725, etching. Getty Research Institute (photo Getty Research Institute, Research Library).

of damask and velvet, gold and silver vessels, crystal chandeliers, and tapestries were the stock-in-trade of the festival-hanger.

Giuseppe and Pietro Eppe Fornari presented a separate bill dated 28 June 1759 "for work done ... at the Palazzo Farnese for the Chinea." 59 On the bill itself, master of the household Orlandi wrote, "I approve the present bill for 40 scudi according to custom." This remuneration compares favorably with that received by other festival-hangers who worked on contract. ${ }^{60}$ As can be inferred from in-kind payments, the Fornari supervised a

${ }^{59}$ AC, I.A.436/78: “Conto Delli lavori fatti . . . al Palazzo Farnese per la Chinea ... Per Manif.ta di avere apparato tutti due l'Appartamenti del Palazzo Farnese con diversi apparati come il solito, è messo tutti li baldacchini, bandinelle, lampedarij, placche, è ramate alle finestre, et altro in Occasione della rappresentazione della Chinea, è poi sparato, è rimesso ogni cosa al suo luogo d'accordo scudi quaranta." A bill for normal services has the same title without the specific location and purpose. In 1754 the Fornari's shop was "à S. Marco"; AC, I.A.393/56. The family was active in the 1670 s; see E. Tamburini, "Le feste dei Colonna: La Contestabilessa e Giovanni
Paolo Schor," in Fagiolo, 2:139. Giuseppe and Domenico Eppe worked during the jubilee of 1725; see M. C. Basili, "Le feste dei Doria Pamphili," in Fagiolo, 2:140.

${ }^{60} \mathrm{Cf}$. payment to a festival-hanger at work in the church of SS. Trinità de Pellegrini: "Al Festarolo cioè [scudi] 60. per l'obligo d'Apparare, e Sparare la Chiesa, ed Oratorio in tutte le Feste dell'Anno, Anniversarij, ed altre Funzioni a tenore dell'Apoca, e [scudi] 10.60 per la Paratura fatta il giorno di S. Filippo Neri compresoci il Nolo di num. 8 Arazzi serviti per la Comunion Generale [scudi] 70.60"; Entrata, viii. The festival-hangers here 
large team..$^{61}$ The pair state that they outfitted the suite of the salotto dipinto (which from November 1758 was used to store Chinea-related materials) and the plenipotentiary's apartment. They set up baldachins, curtains, chandeliers, mirrored sconces, copper screens, "and other things" that were dismantled and put away after the festivities, "each thing in its place." ${ }^{62}$ The festival-hangers' art materially differentiated the individual rooms of the reception suite. ${ }^{63}$ Curtains were similar to those used in state beds, thrones, and altars. Among the "other things" not explicitly named were tapestries, a standard component of interior decoration; forty tapestries had been rented from Jewish merchants for the Chinea of $1756 .{ }^{64}$ Copper screens helped block direct views from the square into the grand reception rooms and also deflected stray fireworks. ${ }^{65}$ The mandate that the king's representatives protect royal property in Rome

had to set up and dismantle several times in 1775, a holy year that placed extra pressure on them, for their work was much in demand and subject to exacting scrutiny. Expenses for candles, for example, were recorded "[p]er la Festa di S. Filippo più solenne per esser l'Anno Santo lib. 25"; ibid., ix. Festival-hangers installed sconces, chandeliers, and the like, so an increase in candles meant an increase in work.

61 "Alli festaroli," 12 jugs; "Alli med.i," 6 jugs; "Alli festaroli," 24 loaves. A further disbursement is recorded in July: "S.re Pro darete Boccali Dodici Vino alli Festaroli per beveraggio dell'Achinea li 28 Lug.o 1759.”

${ }^{62}$ A Neapolitan festival book defines placca: "per tutta la lunghezza della galleria, era anche il numero degli specchi, o sia placche, con loro cornucopie indorate, tutte di lumi di cera doviziosamente splendenti"; Descrizione delle feste celebrate dalla fedelissima città di Napoli per lo glorioso ritorno dalla impresa di Sicilia della sacra maestà di Carlo Borbone Re di Napoli, Sicilia, Gerusalemme, Ec (Naples 1735) 14. Cf. this account of the "gran sala del Palazzo di Campidoglio" for the presentation of prizes to the winners of the competition (concorso) at the Accademia di S. Luca: "[d]avano risalto al detto grandioso apparato 24 . placche di cristallo, con sue candele"; Chracas, no. 6429, 23 Sept. 1758, 13. Rented from a glazier, the sconces used for the Chinea of 1759 were probably made of a wooden frame with a mirror in the center that reflected candlelight.

${ }^{63}$ AC, I.A.445/94: “Conto Delli lavori fatti al Palazzo Farnese per la funzione della Chinea . . . =A di 25: Giugno $1760=/$ Per avere apparato all'appartamento di sopra, cioè apparato con arazzi ad un altezza la sala delli servitori, e fattoci il suo celo d'arazzo da capo tirato à forza di bollette, et appuntati per tutt'attorno [scudi] 1:50; E per avere apparato la prima Cammera doppo la sala con arazzi, è damaschi, cioè messo la prima altezza da capo d'arazzi è fattoci le sue pieghe à confronto delli med.i con bollette tirati, et appuntati per tutto. Segue per avere attaccato con bollette da piedi alli med.i arazzi l'altr'altezza di damaschi per tutt'attorno la med.a stanza tirati, et appuntati per tutto [scudi] 2:50; E per avere apparato la seconda cammera appresso la med.a con arazzi da capo per tutt'attorno con bollette, è sotto li med.i attaccatoci l'altr'altezza di damaschi per tutt'attorno la med.a stanza tirati, et appuntati per tutto [scudi] 2:50; E per avere apparato la terza cammera parimente di due altezze, cioè la prim'altezza da capo apparata con apparati di felponi da capo alle 4: facciate, è nelle cantonate da fianco alli med.i apparate di damasco cremisi tirati, et appuntati per tutto. Segue per avere apparato la second'altezza sotto alli med.i Felponi, è damaschi con teli staccati di broccati gialli, e teli staccati di velluto con impazzimento spillati tutti li teli tirati, et appuntati per tutto [scudi] 3:50." The festival-hangers' itemizations came to 76 scudi, which Orlandi reduced to 30 .

${ }^{64}$ AC, I.A.417/227: "Lista di Spese fatte, e Danari pagati in Serv.o dell' Achinea del Cor.te Anno 1756 ... @ di 21 d.o [June] . . Per porto di Arazzi n.o 40=dal Ghetto nel Palazzo di Piazza farnese [baiocchi] :30." A portion of the bill itself follows: " $=1756=$ L'Ecc.mo Pnpe S.r Don' Lorenzo Gran Contestabile Colonna, deve dare, a Salvatore Sesse Ebreo per' Nolito di N.o 40 - Pezzi d'Arazzi dati per Servitio delli Fochi in Piazza Farnesi, serviti per giorni Cinque, in occasione della presentazione della Chinea del Corrente anno 1756, a [baiocchi] $30=$ il pezzo di Nolito [scudi] 12; E per' riporto pagato di detti Arazzi dal Palazzo Farnese, in Magazzeno in Ghetto [baiocchi] 30." This bill was cut to 6 scudi by Andreini; payment was registered on 28 Jan. 1757; AC, I.A.419/52. In 1755, "Angelo Isach Tagliacozzo Ebreo" was paid 27.10 scudi "per il Nolo di diversi Arazzi, Abbiti, e Letti”; AC, I.B.48, fol. 1507 left.

${ }^{65}$ AC, I.A.322/258: "Conto Dè Lavori fatti ad'uso di Ramaro ... in occasione della Chinea di 28: Giugno 1745= / Si son date n:o 10 Ramate per Servizio delle finestre del Palazzo fernese per riparo de Razzi del fuoco che à giuli tre per Ramata Cosi solito pagavasi imp.a [scudi] 5:70; è piu per porto, è riporto per li facchini [scudo] :40 / Si Sono Riceute e poi Conzegniate le Sud.e Ramate [signed] Alberto Ludovisi dispenziere." Despite mentioning what was "usual (solito)," coppersmith Mauro Causi received only 4:10 scudi. Cf. the following: "Conto de'lavori ad uso di Ramaro fatti ... a tutte spese, e fatture di Belardino Agostini Ramaro . . . =A di 23 Giugnio 1760=Per haver 


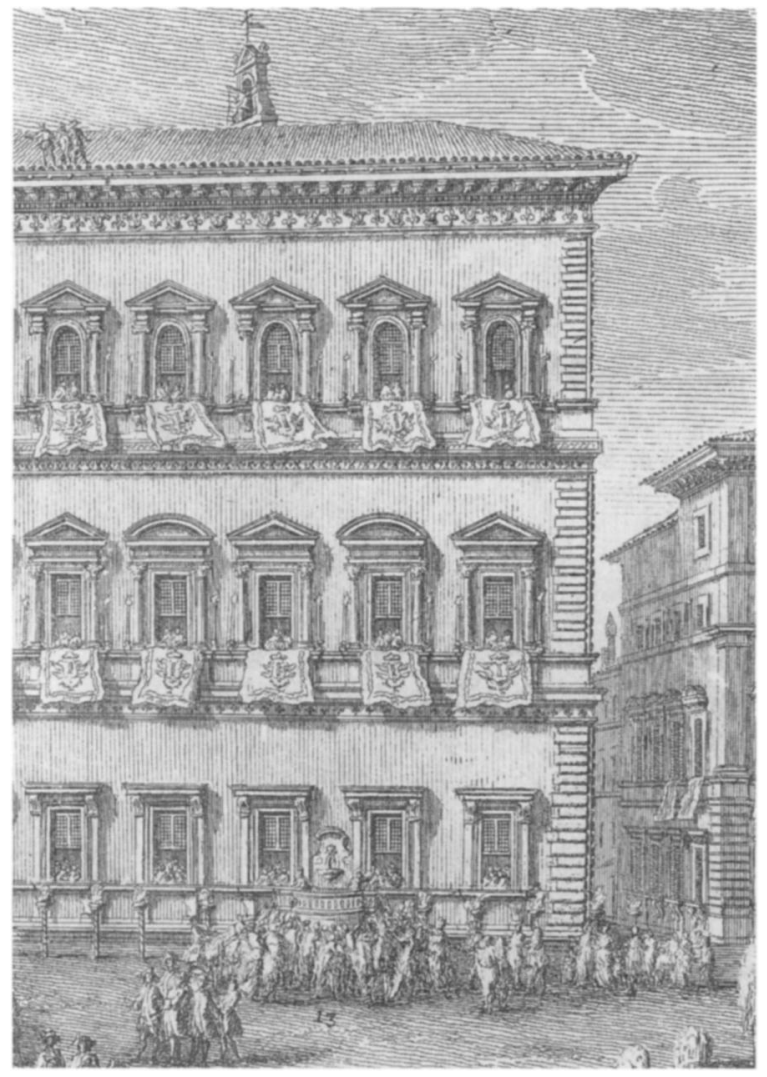

Fig. 8. Vasi, cavalcade for the first presentation of the Chinea by Lorenzo Colonna, 1756, etching, detail of men on roof and fountain of wine. Getty Research Institute

(photo Getty Research Institute, Research Library).

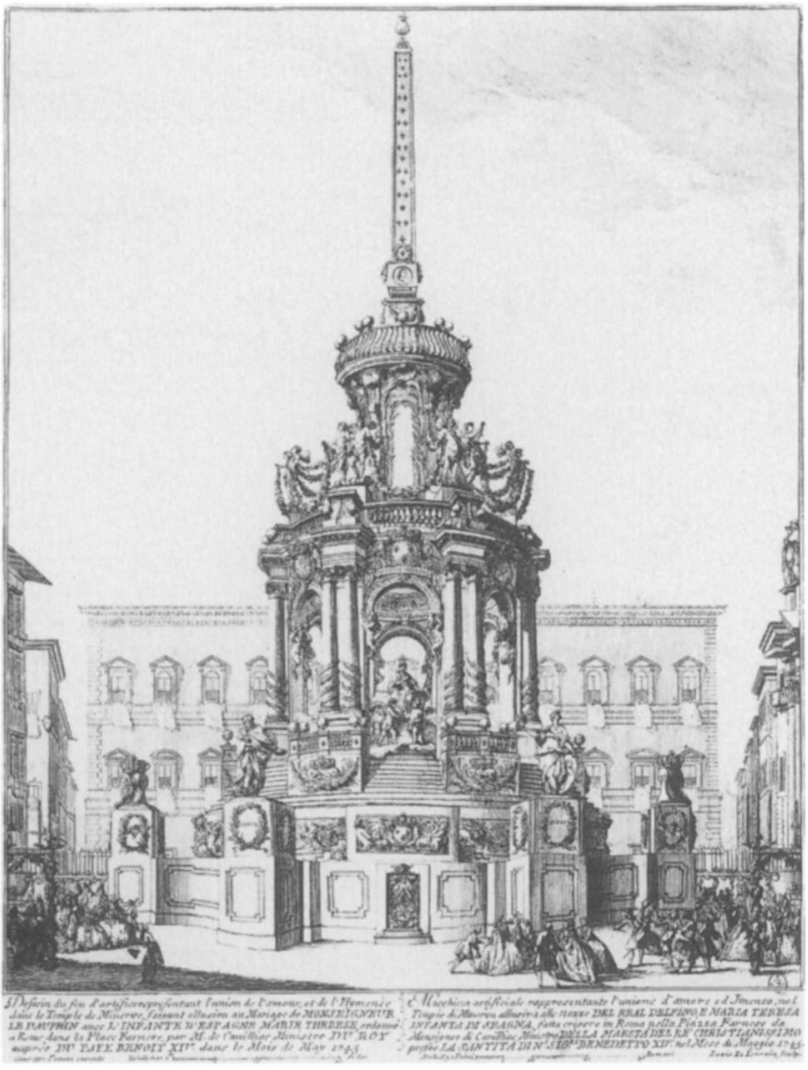

Fig. 9. Jacques-Louis Le Lorrain (after Giuseppe Panini), set piece built in Piazza Farnese for the marriage of the dauphin Louis and Maria Theresa of Spain, 1745, etching. Biblioteca Casanatense, Rome (photo courtesy of Ministero per i Beni e le Attività Culturali).

explains their direct (and unusual) assumption of one Chinea-related expense. Dionigi recorded payment to four masons, who, "according to custom, stood on the roof of [the Farnese palace] the two nights of the fireworks for the Chinea" in order to locate and defuse fireworks and, if necessary, extinguish fires ${ }^{66}$ Similar figures are depicted in Vasi's commemorative etching and in Jacques-Louis Le Lorrain's etching related to the set piece built to celebrate the 1745 marriage of the dauphin Louis (figs. 8, 9).

A canvas by an anonymous late seventeenth-century painter depicting The Presentation of the Chinea in St. Peter's Basilica allows us to visualize the festival-hangers' work (fig. 10).

staccate da tre telari vecchi le ramate, che servono per il foco, e messe inchiodate sopra li telari novi ripezzate, e riprese diverse maglie dove bisogniavano con filo di ferro novo [scudo] :60"; AC, I.A.445/72.

${ }^{66}$ AS, AER 1079: "Bilancio dalli 17 Agosto à tutto li 9. Ottobre dell'anno . . . . A quattro uomini che secondo il solito stiedero sul tetto di d.o Palazzo le due sere de fuochi per la Chinea [scudi] 1.20." The individuals' occupation is found in AS, AER 1080, "Effetti Allodiali
Farnesiani in Roma, e nello Stato Pontificio . . . Spese forsoze certe Annuali come appo ... Quattro Muratori di Guardia al Real Palazzo Farnese le sere de Fuochi di S. Pietro [scudi] 1.20." When a curtain caught fire in the third-floor reception rooms used by the constable's wife, "io, che mi trovavo nello stesso appartamento, feci subito chiamare i Muratori, che di mio ordine stavano sul Cornicione, e sopra i Tetti appunto per accorrere in caso di bisogno rispetto i Tetti medesimi"; AS, AER 1244 (letter from Rome of Giovanni Porta dated 30 June 1739). 


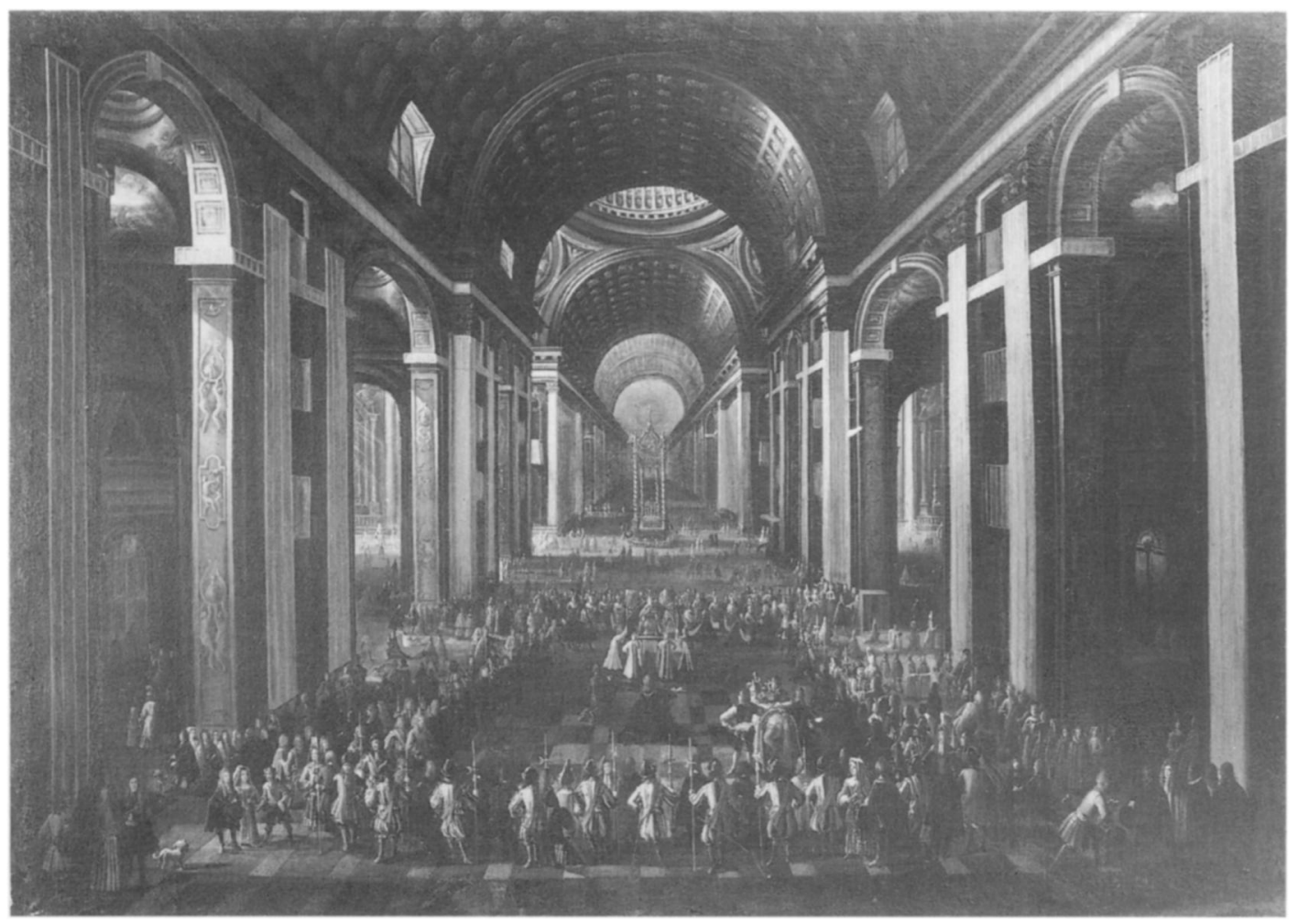

Fig. 10. Presentation of the Chinea in St. Peter's Basilica, late seventeenth century, oil on canvas. Museo di Roma (photo Archivo Fotografico del Museo di Roma).

Tall panels of red cloth with gold thread cover the masonry pilasters in the nave and transept arms, preserving their proportions and even imitating their channeling. Between these tall panels three levels of similar cloth hang in the guise of tapestries; the topmost, bedecked in its upper half with red-and-gold cloth, frames the windows of the small balconies (coretti), from which spectators who needed to remain incognito-Protestant women on the Grand Tour, for example, or the Stuart pretender to the British throne-could observe the ceremony. ${ }^{67}$ Passing behind the tall panels at the level of the pilaster capitals of the intradoses, a frieze of cloth lends a scaffoldlike delicacy to a ponderous architectural membering. Above the capitals of the giant pilaster order, a continuous frieze of red-and-gold cloth wraps around the entire basilica. The festive transformations that Cardinal Polignac, chargé d'affaires of Louis

${ }^{67}$ Dresden, Sächsisches Hauptstaatsarchiv, Geheimes Kabinett, H.St.A 662, "Depeschen und Briefe des Grafen von Lagnasco aus Rom. 1754-1756" (letter-from Rome of Lagnasco dated 5 July 1755): "Domenica, Sire, Festa di S. Pietro il Papa ha voluto pontificare per fare piacere alla Margravia di Bareith, a cui ha dato in S. Pietro un piccolo Coretto vicino a quello de' Musici, perchè avesse tutto il comodo di vedere la Funzione colla sua Corte, e le ha destinato il Conte Petroni per servirla"; see also n. 248 below. Chracas' report of the octupule canonization in 1726 mentions "quattro coretti, o vogliam dir loggie, sotto la cuppola"; quoted in V. Casale, "Addobbi per beatifica- zioni e canonizzazioni: La rappresentazione della santità," in Fagiolo, 2:57. "Fu perciò nobilmente apparato quel già per se stesso magnifico sagro Tempio [SS. Apostoli], di damaschi cremisi trinati d'oro, con bellissime cascate, tripponcini, ed ornati corrispondenti, con il trono pontificio eretto nella gran tribuna, e preparato nel coretto stabile di quei Religiosi Min. Conventuali, situato più in alto sopra il medesimo trono, un signorile bene adequato comodo per Sua Maestà il Rè della Gran Brittania . . . affinche di là potesse agiatamente godere la funzione sagra, il che poi non seguì per trovarsi la Maestà Sua in quel giorno accaggionata"; Chracas, no. 6456, 25 Nov. 1758, 3. 
$\mathrm{XV}$, sponsored for the canonization of St. John Nepomuk in 1729 turned the Lateran, already "magnificent in itself," into a church in which "one [could] see nothing more beautiful." ${ }^{68}$ In the Gesù and S. Ignazio, to mention only two Roman churches, rusted pins driven into pilaster bases and elsewhere still attest to the swaths of expensive woven cloth that once temporarily masked stone and stucco.

The treatise Castelli e ponti di maestro Niccola Zabaglia sheds additional light on the festival-hangers' craft. Published in 1743, it includes fifty-four large, legible, and meticulously engraved plates followed by explanatory texts in Latin and Italian. The generous dimensions of the plates, which allow for extreme clarity of presentation; the visual decomposition of a whole into details to show the structure and interconnection of individual parts; the efficient written text, keyed by letters to engraved images; even disembodied hands emerging from delicately cuffed wrists-all of these well-known modes of didactic representation are present in this book.

At a young age Zabaglia began work at the busy architectural laboratory of the fabbrica di S. Pietro; even in adult life, he remained illiterate. He nevertheless applied "his natural talent" to observing how mechanisms worked to support and resist weights. He used alreadyexisting tools perfectly and designed new "machines" admired for their "simplicity and ease of operation," wrought so as not to damage "walls or ornaments." One plate from the treatise represents a mechanism that enabled festival-hangers to move along the cornice of St. Peter's in order to attach the bunting or embroidered cloth that formed part of its festive outfitting, the very type of decoration to be seen in the painting (fig. 11). When a pair of festival-hangers had to descend the ladder (specifically made of mature ash), a colleague standing on top of the cornice immobilized it by manipulating a series of screws. He would push or pull the mechanism, whose wheels rolled on a wooden beam, so as to follow the movements of his colleagues below. Another pair of wheels ran against the bottom of the frieze to effect a smooth gliding. Remarkably nonchalant, the festival-hangers move along a surface 2 palms $(.45 \mathrm{~m})$ wide, and 120 palms $(26.81 \mathrm{~m})$ above the ground.

The brevity with which the Fornari recorded services rendered on the separate bill depended upon mutual expectations established over time or, in other words, a long-standing patron-client relationship. Loquacity and telling detail characterize entries in another bill that records a year's worth of work. Services performed in the Farnese palace correspond to the constable's extraordinary embassy. Yet the same artisans who worked at an agreed sum each year for the Chinea were subjected to the exacting scrutiny of the warden (guardarobba) Antonio Belli for other projects; they received slightly less than half of what they requested. The Fornari removed eight chandeliers on 3 December 1759. On 18 December they returned to the palace to "remove all the chandeliers that were in the apartment," erecting ladders "under the attic [sotto al solaro]" (fig. 12, A, B, C, D). Some of these rooms corresponded to a suite on the second floor below that Caterina Salviati, Fabrizio Colonna's wife, had rarely (because of differences in protocol and pretensions) used to receive female guests in 1738, 1739 , and 1740 (fig. 13, A, B, C) ${ }^{69}$ Chandeliers installed for the convenience of the constable's

\footnotetext{
${ }^{68}$ Paris, Archives du Ministère des Affaires Étrangères, Correspondance politique, Rome 704 (letter from Rome of Polignac to count de Gergy dated 26 July 1729): "Nous avons fait aujourd'huy à S.t Jean de Latran la Canonization de S.t Jean Nepomucene. Cette Eglise magnifique en elle mesme, est superbement parée, et on ne peut rien voir de plus bel."
}

${ }^{69}$ AS, AER 1244 (letter from Rome of Giovanni Porta
dated 30 June 1739): "Dopo la Girandola venne [the elec-
toral prince of Saxony] à questo Real Palazzo ricevuto, e
servito dalla Sig.ra Contestabilessa in un Appartamento
del terzo Piano ammobiliato espressamente per Lei
appunto per servire la Reale Altezza Sua, e per ricevervi
la Principessa Corsini Nipote di Sua Santità, non 


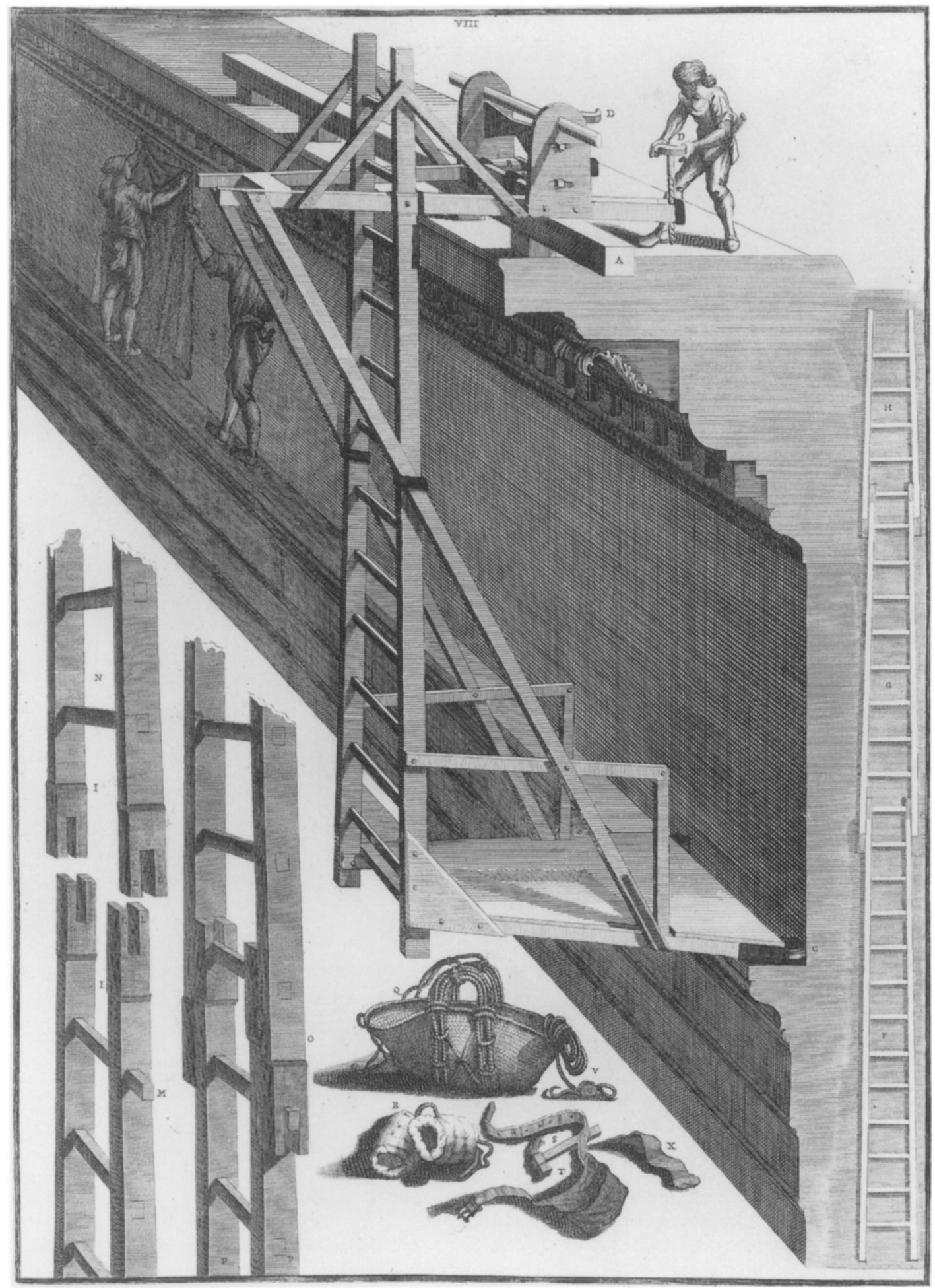

Fig. 11. Festival-hangers applying cloth decoration to a frieze in St. Peter's Basilica, engraving from Zabaglia, pl. VIII (photo Getty Research Institute, Research Library). 
Fig. 12. Rome, Palazzo Farnese, plan of third floor; from [École Française de Rome], Le Palais Farnèse, 2:407.

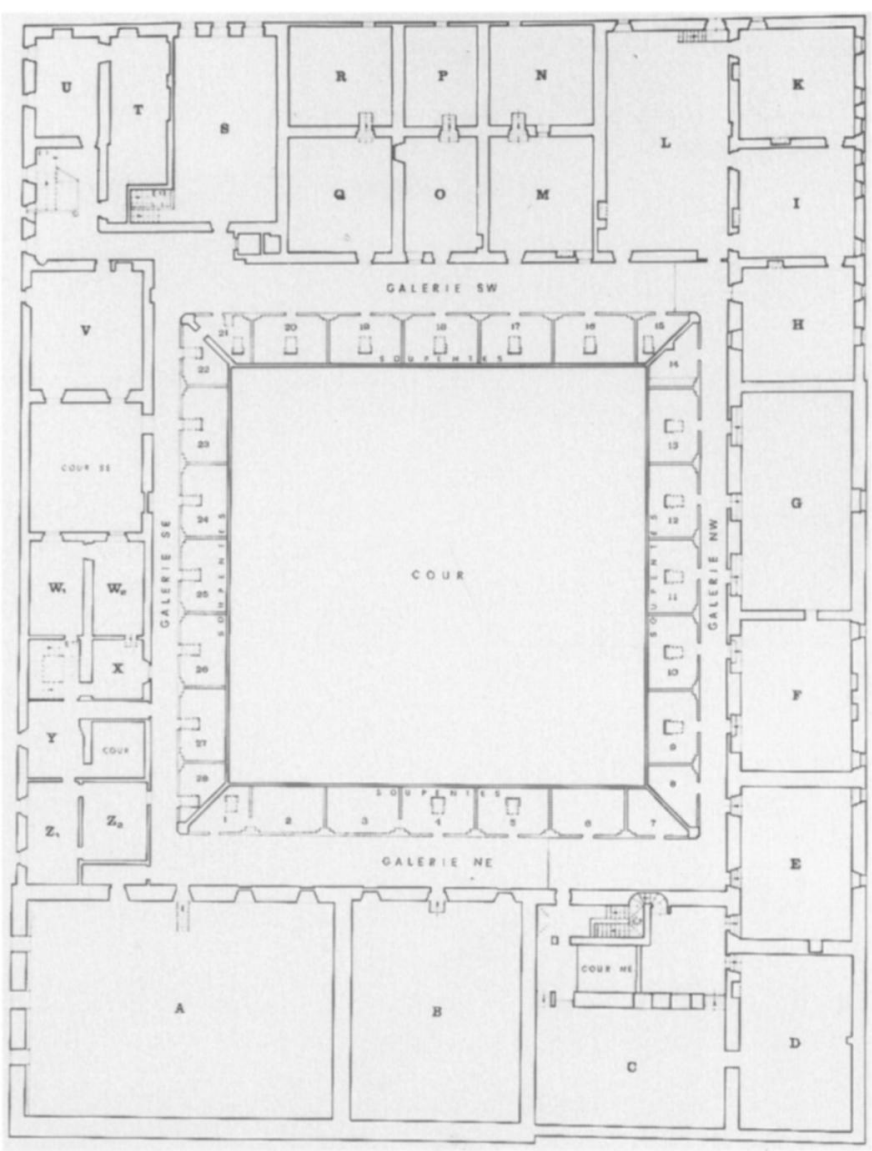

wife-in other words, temporary changes in outfitting that had become permanent-were taken away. When Orsini learned that this suite had not recently been used, he decided to lodge members of his retinue there, reserving access to the only upper-floor windows from which one could observe the Chinea fireworks displays. ${ }^{70}$

The festival-hangers detached twenty-two cords connecting the chandeliers to hooks driven into rafters that supported the palace's pitched roof. ${ }^{71}$ Hoping to obtain the desired payment, the men described the "great effort" expended to accomplish the task, an activity difficult to verify; citing effort, discomfort, attention, or diligence as a component of the value of labor was, however, not unusual. ${ }^{72}$ Finally, the Fornari dismantled a baldachin in an un-

ricevendo altre Principesse, e Dame, per la difficoltà, che queste anno sempre avuta di prendersi la mano manca dalla detta Sig.ra Contestabilessa, che in questi giorni fà figura di Ambasciadrice, e come tale secondo l'etichetta del Paese non dà la mano anche in Casa propria, che alle sole Nipoti del Papa." "lo sopraccennato Appartamento, che nelle trè decorse presentazioni della Chinea hà servito nè due giorni dè consueti Fuochi d'Artificio per la Dama Moglie dell'Ambasciadore Straordinario"; AS, AER 1251 (letter from Rome of Giovanni Porta dated 24 Dec. 1740).

${ }^{70}$ For Orsini's decision, see G. Michel, 556. These win- dows were important, "non essendovi altro commodo nella facciata principale di questo Palazzo, che quello di detto Appartamento [per] godere dalle sue Finestre le due Machine di Fuochi Artificiali"; AS, AER 1251 (letter from Rome of Giovanni Porta dated 24 Dec. 1740).

${ }^{71}$ For photographs of the third-floor rooms, see [École Française de Rome] 344-45.

72 Between 1670 and 1676, artisans installed hooks for fabric or leather hangings in the Borghese palace "con scomodo su le scale"; P. Waddy, Seventeenth-Century 


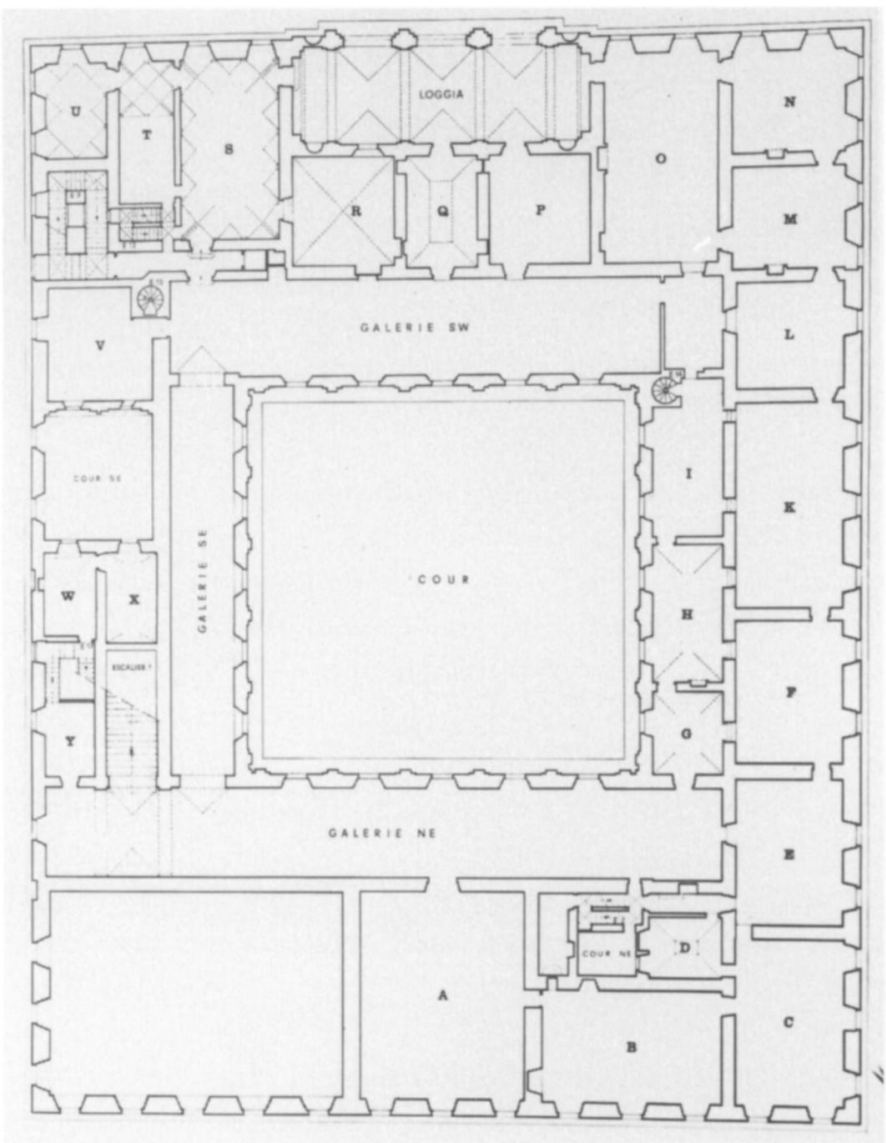

Fig. 13. Rome Palazzo Farnese, plan of second floor; from [École Française de Rome], Le Palais Farnèse, 2:409.

specified room. Using ropes, pulleys, and long ladders, they took from its supporting frame the fabric of the baldachin, which was then dusted and folded. This last activity may have been linked to Orsini's unwillingness to remove the baldachin with his own coat of arms from the audience room of his apartment.

Other details in the engraving from Zabaglia explain the Fornari's work (fig. 11). The "extension" of a ladder comprised three distinct pieces: the lowermost had twelve rungs, the middle from eleven to six, the topmost from five to two. Firm junctures were guaranteed by metal-covered tenons that grasped both the bottom rung of an upper section and "ears" that projected from the side pieces of a lower. Depicted as well are some tools proper to this vertiginous work: a basket with a hook that could be attached to the rung of a ladder; mittenlike "cushions" to slip over the side pieces of a ladder resting against a wall; an apron from which a hammer hangs; and a cloth band, "full, and packed with pins for attaching the decorations, which festival-hangers wear on the left wrist."

Roman Palaces: Use and the Art of the Plan (Cambridge, Mass. 1990) 350, n. 78. For "going crazy" (impazzimento) as a category for payment, see n. 63 above. Cf. these vinous payments from 1754: "Sig.r Pietro della Bitta Canevaro potrà dare a Mro pietro de Santis capoccia de Falegnami, barili due Vino per l'attenzione usata nel dimettere le due machine de Fuochi"; "Sig.r Pro della Bitta Canevaro potrà dare ad Agostino di Giorgi Festarolo bocali Sedici Vino ... per recogn.e della diligenza usata nelle Torce della Sala del Palazzo Farnese in occasione della Chinea"; AC, I.A.394/200. 
Paid quite differently for the various services rendered, the festival-hangers carried out essential tasks in the days immediately before the ambassador extraordinary received guests in 1759 and later that same year, when a new plenipotentiary called for alterations in the royal palace. Having originally implemented the changes, the Colonna were ultimately responsible for dismantling them and turned to the team they had engaged for the Chinea for many years.

The festival-hangers placed copper screens at the windows that face the piazza Farnese and took them down after the receptions. The screens, supplied by coppersmith Bernardo Agostini, were received by Matteo Taliani, Lorenzo Colonna's "secret sweeper," on 25 June; three days later, the festival-hangers installed them. ${ }^{73}$ Agostini brought the receipt to the Colonna administration on 30 June; there master of the household Francesco Andreini appended what was a frequent notation, which begins with the phrase "I the undersigned." This phrase verifies which artisans were able to write; often the illiterate were directed to draw a glyph between the two syllables of the Italian word for "cross," producing the configuration Cro $+c e$. This common signature is an index of the visual culture of the period, for although unused to manipulating an inked quill and incapable of writing letters, they could draw two lines, unequal in length and roughly intersecting at right angles. Andreini acknowledged receipt of the screens, assigning them a value of 6 scudi. Since Agostini "said he did not know how to write," Andrea Dotti of the Colonna administration signed his own name "by commission," following common practice. Agostini also got a portion of wine. ${ }^{74}$

Glazier Giovanni Rinaldi presented a separate bill for Chinea-related expenses. ${ }^{75}$ That he and his family were the glaziers of choice may be explained by the location of the shop, "underneath the palace of the most excellent Casa Colonna." 76 Rinaldi and his crew began work on 13 June, so the plenipotentiary had to tolerate disruptions and the presence of workers in his apartment early on, to say nothing of the commotion that accompanied the rising set piece in the square. They cleaned twenty large lustres of Bohemian glass, adjusted them, "made them like new," and added twenty sockets of tin plate that supported lily-shaped finials made from rounded glass droplets. ${ }^{77}$ To another lustre were attached eleven similar sockets and one ball beneath. Rinaldi performed 107 solderings with silver-coated copper wire, each threequarters of a palm (ca. .17 m) long. A third lustre with large glass beads required cleaning, adjustment, and the replacement of some beads. Rinaldi was fully reimbursed for the cost of raw materials, so their value was well known and not a matter of debate. The cost of brass

${ }^{73}$ AC, I.A.443/152: "Io sotto scritto ho riceuto dal Sig.r Bernardino Agostini pezzi di ramate n.o 36 in fede questo di 25 Giugno 1759 Io Matteo Taliani [the next section is written in Andreini's hand] Io Infratto fò fede come Bernardo Agostini hà ricevuto dal Sig.re Fran.co Andreini ... Scudi Sei mta per pro delle sud.e n.o 36=Ramate $E$ perche disse di non saper scrivere hò fatto la pnte di sua Comm.e li 30 Giug.o 1759 [signed] Andrea Dotti di Commissione." In 1763, "Belardino Agostini Abita al vicolo del Goveno Vecchio”; AC, I.A.469/149.

74 “A Bernardo Agostini Ramaro," 4 jugs.

${ }^{75}$ AC, I.A.437/131: "Conto Delli Accommodature delli Lampadare, Nel Pal.o Fernese, è Noliti dati de Lampadari e Placche Nell'anno 1759 In Occasione della
Rappresentazione della Chinea." Requesting 26.29 scudi for Chinea-related services, Rinaldi received only 16.31 . Uncut reimbursed costs of raw materials were: pater nostri (.20 scudo); fil d'ottone filato (.05 scudo); stagno (.05 scudo); specchietti (.24 scudo).

${ }^{76}$ As on a bill of 1762 , "Girolamo Rinaldi Vetraro Sotto il Pal.o Dell'Ecc.ma Casa Colonna”; AC, I.A.459/105.

${ }^{77}$ AC, I.A.437/131: "Per. averci fatto n.o 20. Bocchalie de latta, per. formare sop.a una Gulia, di Goccia arotata." A boccaglio was also a socket in a torchière: "[l]i detti torcieri sono di altezza palmi 15 . e di peso libre 275 . l'uno ... Il loro piedestallo, ed il boccaglio da sostenere il cero è di metallo dorato"; Chracas, no. 6069, 5 June 1756, 13. 
wire (fil dottone) was not cut, but that of nine glass pendants for the underside of the same lamp was reduced from .45 to .30 scudo. Rinaldi kept tin and small mirrors on hand, for whose cost he was fully reimbursed.

To carry out these adjustments and repairs, a man from Rinaldi's workshop worked for two days, "put[ting] into place a large quantity of things that Sig. Matteo gave [him]." Secret sweeper Taliani, therefore, performed tasks far beyond what his literal title might suggest. Rinaldi's assistant helped the festival-hangers install ten sconces rented from his boss and all of the objects mentioned in the bill. He earned .20 scudo per day for his labors. The glaziers "Gaetano and Giacomo Rinaldi" also received a vinous payment. ${ }^{78}$

After the festival-hangers and others had finished their work, the constable's secret sweepers gave the reception rooms a thorough cleaning. ${ }^{79}$ That activity completed, the spaces were ready for their ephemeral use. Home to an ambassador, some minor Neapolitan nobles, a Sicilian-born printmaker, and a washerwoman, among others, the Farnese palace housed the very fabric of Roman society, but that building had to be altered for the constable to discharge his embassy decorously and splendidly.

\section{Building and Decorating the Set Pieces}

The plans, sections, and elevation of the armatures having been drawn up, capable, active, and numerous workers must be selected to carry out the project in a short amount of time, if the cause of the celebration could be foreseen in advance; for diligence in execution is necessary to please the public, ordinarily impatient to see the promised festival, $\ldots$ as joy seems to diminish and use itself up over time. ${ }^{80}$

The Encyclopédie of Diderot and d'Alembert includes numerous entries on the components of festivals. The quoted passage describes the construction of an armature (théatre) for a fireworks display and implies the existence of a festival industry and skilled labor proper to it. Unlike many large-scale celebrations, the Chinea was an annual event. All parties involved depended upon the very history of the festival's production as new plans were drawn up. I turn now to the activities undertaken to build and decorate the Chinea set pieces of 1759 (figs. 1,2). Extant archival and other contemporaneous sources permit an analysis of a sphere of artisanal activity often unacknowledged in etchings, printed descriptions, and newspaper accounts related to festivals, activity that bears an explicit connection to the history of architecture in terms of the character and organization of an on-site workforce and the materials adopted in building set pieces.

\section{LAW AND ORDER}

The newspaper of eighteenth-century Rome reports that the Chinea set pieces of 1759 were 300 palms $(67.02 \mathrm{~m})$ in length (figs. 1,2$){ }^{81}$ While parts of the structures were fabricated in

78 "A Gaetano, e Giacomo Rinaldi," 2 jugs; "A Gaetano Rinaldi," 2 loaves; "A Giacomo Rinaldi," 2 loaves.

${ }^{79}$ AC, I.A.394/200: "Sig.re Pietro darete Boccali Sei Vino a Matteo Taliani, e Filippo Scianuin' perche aver spolverato l'appartam.to del Palazzo a Farnese in Occne
dell'Achinea li 19 Giug.o 1754."

${ }^{80}$ Diderot and d'Alembert, 1:s.v. "artifices."

${ }^{81}$ Chracas, no. 6552, 7 July 1759, 11. 
various ateliers throughout Rome, the wooden armature itself was constructed in place. $\mathrm{Nu}$ merous payments are recorded to men who acted as security guards. Initially, building materials like wood, nails, rope, lead pipes, and perhaps masons' and carpenters' tools were found at the work site, all objects with monetary value and practical usefulness; for example, in 1759 , the price of rope alone was $32.50 \mathrm{scudi}$, while one guard's service was explicitly linked to lead pipes. ${ }^{82}$ Risks of theft, vandalism, or even attacks against the workers made it impossible to leave the building site unattended; those risks increased as the set pieces took final shape and continued even after the explosion of the fireworks. ${ }^{83}$ In the case of the set piece erected in 1745 to celebrate the marriage of the dauphin Louis, sculptures were "blackened and ruined," acts apparently committed by individuals moved by their dislike of France (fig. 9). ${ }^{84}$

Three guards-Pietro Montelli, Agostino Ambra, and Antonio Malanotte-earned a total cash payment of 35.25 scudi for what among them amounted to 141 working days. Each received .25 scudo for a day's work. Montelli and Ambra began service on Tuesday, 15 May, a week after the last artist's contract was signed in the offices of the Colonna administration. Malanotte was first paid on Saturday, 2 June, for having guarded for five days the "upper loggias" (loggie di sopra), which may indicate that in two weeks' time the armature had been raised up to the ground level of the castle and towers shown in Vasi's etching (fig. 1) ${ }^{85}$ All three men shared portions of wine and bread. ${ }^{86}$ Guards kept vigil round the clock, especially in the days immediately preceding 28 June. Grouped at the end of Andreini's petty-cash report are miscellaneous receipts, including three to the day guards signed by Giovanni Battista Grossi, sculptor and construction manager. Malanotte was paid for six nights' work for having

${ }^{82}$ AC, I.A.436/66: "in occasione delli Fochi del Anno 1759 . . . Il Nro Comp:ta dia Credito nel Conto di Giuseppe Tendel Funaro di Scudi Trentadue, e [baoicchi] $50 \mathrm{mta}$..." For the guarding of lead pipes, see n. 87 below.

${ }^{83}$ See Appendix, doc. 7, for the rationale for engaging guards. In 1754 a tinsmith described precautions against theft: "per avere messi in opera due [condutelli] per ogni fontana [di vino] nelle taze e per averli stucate forte con canepa e stuco di dentro e di fuori con le zeppe di ferro infogate che sono nu.o 8 stucature e fermati con li chiodi acio non li potessero robare per robba tempo e fa. @ [baiocchi] 15 l'una [scudi] 1:20/:80"; AC, I.A.393/185. As for threats to the workers, the bishop of Gurck informed count Traun, governor in Milan, that "[i]l Popolaccio poi non ha avuto riguardo alcuno di sciamazzare [per] le strade, ed ai Lavoratori dei Fuochi nella Piazza Farnese dove ha stimato bene questo Governo di far raddoppiare le Guardie"; Milan, Archivio di Stato, Potenze estere Roma 118 (letter from Rome dated 30 June 1742). Permanent works of art could also be subjected to vandalism, as famously in the case of Michelangelo's David: after its removal from the Florentine Opera del Duomo, "[d]uring the night stones were thrown at the giant to injure it, therefore it was necessary to keep watch over it"; A Florentine Diary from 1450 to 1516 by Luca Landini, trans. A. De Rosen Jervis (London 1927) 214.
${ }^{84}$ ÖS, RK 134 (letter from Rome of Giovanni Battista Ruele, imperial agent and archivist, dated 8 May 1745): "Questi Romaneschi, che sono naturalm:te d'un genio contrario à tutto ciò che possino fare, così li Francesi, come li Spagnuoli, già principiano à mettere in ridicolo queste Feste, non tanto con Cartelli satirici, quanto ancora con'andar sporcando le figure che devono esservi esposte, essendosi ritrovato nelle Notti passate sporcati di nero, e rovinati alcuni Leoni Lumeggiati d'Oro: Onde è convenuto di mettervi nella d:ta Piazza le Guardie Pontificie per impedire ulteriori disordini."

${ }^{85}$ On 20 May, Montelli and Ambra were paid "per giornate n.o 6 che hanno fatto la Guardia in Piazza Farnese alle Robbe de fuochi [scudi] 3:"; the two were also paid on 25 May and 2 June. On 2 June, Malanotte alone was paid "per La guardia di giorni 5 che hà fatto La guardia alle loggie di Sopra dalli 29 Mag.o à tutto Oggi [scudi] 1:25." Payments to all three date to 9, 16, 23 , and 30 June (two separate entries); AC, I.A.443/152.

86 "Alli 3 homini che fanno la guardia alli Fochi," 4 barrels; "alli med.i," 4 barrels; "Guardia di dui Sere," 4 loaves; "Guardia di dui Sere," 4 loaves. Since two payments were listed, the wine and bread may have been disbursed on separate occasions. In 1759, the price of wine disbursed for the Chinea was assessed at 1.8 scudi per barrel, with 32 jugs to the barrel, so the cash value of this payment was .45 scudo, .05 scudo less than two days' wages for a security guard. 
guarded large pieces of canvas that formed a canopy in the second set piece (fig. 2). Montelli kept watch from 23 to 28 June "at the line," a phrase that may refer to a rope that encircled the structure to keep people at a safe distance. Ambra watched over the lead pipes for fountains. Montelli worked two extra nights, 2 and 3 July, perhaps with Ambra. ${ }^{87}$ Their overtime shifts added 5.50 scudi to their collective wages. Even when Grossi signed a receipt, the accounting office at times insisted upon verification of a guard's actual presence on site. ${ }^{88}$

Two additional items were necessary for this work. In his June accounts of "various things," Colonna quartermaster Alberto Ludovisi records the distribution of 15 pounds of tallow candles for "the continuous vigils" over the structures. ${ }^{89}$ His bread and wine accounts, which include separate lists of Chinea expenses, name the mattress-maker Domenico Bruni, who received in-kind payments, ostensibly for maintaining the guards' beds. ${ }^{90}$ Two beds had been procured, each for a period of two months, from "Nessime da Nola and Angelo Isache, Jews," who received 2.00 instead of 2.40 scudi. ${ }^{91}$ Jewish merchants in Rome often rented furniture along with tapestries and clothing. ${ }^{92}$

Different groups of soldiers also worked as security guards. Several detachments of grenadiers began their service no later than Sunday, 17 June, as implied by their receipt of 40 pounds of tallow candles. ${ }^{93}$ The grenadiers must have used these candles while they were stationary. Part of their duties included moving around the structure and the square, a fact confirmed by their having received from Ludovisi yellow links bought especially for this purpose and not subtracted from available stores. ${ }^{94}$ The grenadiers' vinous payment corresponded

${ }^{87}$ AC, I.A.443/152: “A Pietro Montelli per n.o 8=Nottate di Guardia fatte [scudi] 2:," with an attached note: "Pietro Montelli per Avere Fatto N:8 Nottate Cioue Sej alla Fila Principiando dallj 23-Giugnio Fino li 28=d.o e $2=$ altre dallj $2=$ Luglio Fino $\mathrm{Li}=3=$ Intutte Sono Nottate n:8." Four jugs were dispensed for two nights' watch (under the rubric "Diversi ... Guardia di due Sere"), which may correspond to the same two nights in July. "Ad'Ant.o Malanotte per nottate n.o 6 [scudi] 1:50; Ad'Agostino Ambra per n.o 8 = Nottate [scudi] 2:," with attached notes signed by Grossi: "Mala Notte per aver fatto N.o 6 nottate alli coritori, per guardar le tele volanti che andavano in opra all'secondo fuoco"; "Agostino di Ambra Per Aver Fatto Sei Nottate à Guardare Li Condotti di Piombo e Altre due Nottate à Guardare la Machina del Fuoco"; AC, I.A.443/152.

${ }^{88}$ AC, I.A.417/227: "Liste di Spese fatte, e Danari pagati In Serv.o dell'Achinea," with attached note: "Lista dell Giornate, e Nottate Fatte alli Focoi Piazzia Farnese dll presente mese di Giugnio 1756 . . . [signed] Gio: Batta Grossi; [verso] Io sotto scritto Per Laverita richiesta fo piena et indubitata Fede, mediante il mio guramento àvanti chi aspeta come alli 25. Gug.o è alli 27 Gug.o ò vedutto Benisimo Come Gusepe Rossi le sudette notte sia statto con tutta atezione tutta la notte e questo lo posò dire èsendo statto Sempre con mè afare la Sudetta Guardia Questò di 2: Lug.o 1756 [illegible name].”

${ }^{89}$ AC, I.A.437/141: "Esito di Candele di Sevo ... Per le Guardie continue delle Robbe de Fuochi [libbre] 15." For the role of the dispensiero, see Liberati, 73-75.
90 "A Dom.co Bruni Materazzaro," 6 loaves; "Al Matarazzaro," 3 jugs.

${ }^{91}$ AC, I.A.443/198: "Per nolito del p.mo letto per la guardia per dui mesi 1:20/1_"; "Per nolito del secondo letto per la guardia di sopra 1:20/1—"; see also n. 64 above.

${ }^{92}$ AS, MP 3447 (letter from Rome dated 24 Jan. 1722): "e giacche la R.le A.S. vuole onorare il detto Giovine [Mauro Soderini] anche dl commodo d'un buon letto, e degl'altri mobili necessarij per detta stanza, stimarei bene piu'tosto, che pigliarli á nolo dall'Ebreo, comprarli di nuovo, poiche faccio conto che con una piccola somma di 20. scudi in circa possa comprarsi tutto il necessario, che rimarrá sempre á commodo dl Palazzo, maggiormente che l'istesso Giovine per quanto dice, vuole trattenersi quâ almeno tre, o quattro anni, e pigliandosi la detta robba á nolo, questi in un anno solo importa quanto il Capitale."

${ }^{93}$ AC, I.A.437/141: "A di 17=per le Guardie alli Fuochi delli Soldati Granattieri” [libbre] 40.”

${ }^{94}$ AC, I.A.437/139: "Torcie a vento gialle per li Soldati e Granatieri ... [scudi] 2:50." According to the Colonna household directives, links made of tow and pitch were used to provide light for people along the streets: "Quella [torcia] di vento si terrà quando si manda lo staffiero ad accompagnare ad alcuno fuori di casa et cio si habbia da osservare ogni giorno"; AC, II.A. $18 / 46$. 
to the number of men deployed. ${ }^{95}$ From 23 June to 2 July, these men received ninety portions of bread, eight large loaves per day. On the days of the festival itself, the ration was increased to fourteen and twelve, a sign, perhaps, of longer days worked, or the patron's holiday largess, or an increased number of guards necessary to control crowds ${ }^{96}$ Sergeant Paolo Piacentini received a generous payment of 20 scudi for "having helped with the companies of the grenadiers." ${ }^{\prime 7}$ Finally, the full complement of security guards included two companies of soldiers who received a portion of the links already mentioned and tips amounting to 14 scudi. $^{98}$

\section{The Sculptor Giovanni Battista Grossi}

"I, Giovanni Battista Grossi, obligate myself as above with my own hand" (Appendix, doc. 1). Thus, on Monday, 7 May 1759, that sculptor signed a contract for work to be accomplished for the upcoming Chinea, a contract that had the same validity as any "public and sworn instrument drawn up by a public notary." Three members of the Colonna administration affixed their signatures to the document, just as a notary would have done. Andrea Dotti wrote the contract out in advance of the official signing, which constituted part of his copyist's tasks, and used a standard legal formula at the end: "I, Andrea Dotti, was present, witness to the above [by] my own hand." When such contracts exist, they are usually found at the beginning of the first volume of justifications of the master ledger; constituting nearly all extant contracts with artists and artisans, they warrant careful study.

Grossi's works not for the Chinea include four stucco reliefs with scenes from the life of St. Nicholas for the church of S. Nicola dei Lorensi. ${ }^{99}$ To an image of the Virgin attached to the Palazzo Muti-Bussi, he added two bas-reliefs, part of a 1752 campaign of embellishments. ${ }^{100}$ He sculpted the funerary monument to Carlo Cardinal Colonna in SS. Apostoli that, completed in the week ending Saturday, 6 April 1754, held the embalmed praecordia of the defunct prelate. ${ }^{101}$ Sadly lost are two works, specifically trionfi da tavola, or large-scale centerpieces-a Neptune of December 1754 and an Apollo and Daphne of January 1755-each sculpted from butter and perhaps gilded. ${ }^{102}$ The location of Grossi's studio in the "Courtyard

95 "Alli med:i [granattieri] in n.o 90 Persone che sono state di Guardia alli Fochi," 90 jugs.

${ }^{96}$ See notes attached to the "Nota de Distaccam.ti della della [sic] Compg.a de Granatieri che anno guardato La Machina a Piazza Farnese dal di=23 Giugno 1759 à tutto li=2=Luglio."

${ }^{97}$ AC, I.A.443/152: "A Paolo M.ro Piacentini Serg.te de Granattieri per Recogn.ne [scudi] 20," with attached note: "Io Infratto hò ricevuto ... Scudi Venti ... per Recog.ne d'haver'assistito con La Compag.a de Granattieri In Occne dell'Achinea, e fuochi li 30 Giug.o 1759."

${ }^{98}$ For the links, see n. 94 above; for Chinea-related tips, see AC, I.A.443/140.

${ }^{99}$ See F. Titi, Descrizione delle pitture, sculture e architetture esposte al pubblico in Roma (Rome 1763) 411; for the church and its decoration, see C. P. Ridolfini, Guide Rionali di Roma. Rione V-Parione, pt. 1 (Rome 1973) 78-80.
${ }^{100}$ See Chracas, no. 5424, 22 April 1752, 6-7, transcribed in Mallory, 174.

${ }^{101}$ See Chracas, no. 5730, 6 April 1754, 11-13, transcribed in Mallory, 175.

${ }^{102}$ AC, I.A.402/331: "Lista di Latticini dati del Procoio delle Bufale, ed altro ... A di 2 Aprile a Gio Batta Grossi Scultore Scudi Tre mta pagatili per fattura di due Trionfi il primo Rapresentava Nettuno fatto di Butiro in Decembre 1754, e L'altro rapresentava Daffine, ed Appollo in Genn.o 1755 [scudi] 3." In 1759, the new ambassador of Malta received from Cardinal Portocarrero "una statua di butirro rappresentante la Carità"; Chracas, no. 6522, 28 April 1759, 17. In 1762 a Venetian noblewoman received from Clement XIII "un Agnello, tutto di butirro di grandezza, e peso delli più grandi di tale specie, sopra un parter di fiori freschi delli più distinti”; Chracas, no. 6987, 17 April 1762, 16. A payment exists to "Franc[esc]o Monaldi Indoratore per diverse indorature di trionfi di biturio e zuccaro servite per le nozze"; J. Montagu, Roman Baroque Sculpture: The Industry of Art (New Haven, Conn. 1989) 219, n. 92. 
of the Peacocks" at the Colonna palace can be securely dated to $1755 .{ }^{103}$ In 1756 an in-kind payment of coal, whose price Grossi and other artists who worked on the Chinea "had to make good" ("doverne far buono il prezzo"), indicates that he served as "house sculptor" for the Colonna. ${ }^{104}$ In that same year, for the "new fountain" located in Rocca di Papa, he sculpted a coat of arms made of travertine. ${ }^{105}$ Around the same time that he signed his Chinea-related contract in 1759, he received the commission for his best-known work, the marble relief of Trivia Pointing Out the Source of the Aqua Virgo, which would be raised into place on the Trevi Fountain shortly before the official unveiling on 22 May 1762. ${ }^{106}$ Girolamo Cardinal Colonna was charged by Clement XIII to oversee this project, so a family connection may also have worked to Grossi's advantage here. Still, in the work of modern scholars, it has not been noted that Grossi was involved in the production of Chinea set pieces between 1754 and $1759 .{ }^{107}$ Of all artists' contracts, his was the most detailed and the most restrictive.

The sculptor was bound to serve as contractor, construction manager, foreman, and so on, taking on roles that architects often assumed in permanent building projects. ${ }^{108}$ In his role as foreman, as we already know, he signed receipts for the security guards. Grossi was "especially" required to extract from "cellars and storerooms ... framework supports, busts [Fusti de Telari, Busti], and everything else that was necessary," a stipulation that proves that many parts of the set pieces remained salvageable, ensuring savings in both cost (for raw materials and labor) and time (a priceless commodity in ephemeral contexts). ${ }^{109}$ After the first set piece was "exploded," Grossi and his crew had to dismantle it "with every diligence," transporting the various components to "whatever site or sites" the architect ordered. The

${ }^{103}$ AC, I.A.408/121: "Conto di Giovanni Ascenzi Ferraro ... Fatta una Campanella ad'Uso di Stalla con'occhietto con'punte doppie serve per La cataratta accanto la porta dello Studio dello Scultore nel Cortile delli Pavoni [scudo] :15/:10."

${ }^{104}$ AC, I.A.411/190: "Nota del Carbone dato d'Antonio Fulcioni Ricevitore del medemo dalli 2 Gennaro, à tutto li 10 Nov.re 1756=alli sottoscritti Artisti, che servono l'Eccma Casa in conto de lavori, e per doverne far buono il prezzo alla rag:ne di [baiocchi] 80 la Soma ... d.o [13 Feb.] à Gio: Batta Grossi Scultore s.e 10." Analogous payments exist for the masons Alessandro Bernasconi and Giovanni Giobbe (20 some), the smith Giovanni Ascenzi (30 some), the brazier Antonio Turchi (20 some), and the tinsmith Carlo Giuseppe Bassetti ( 30 some), all mentioned in the present article.

${ }^{105}$ AC, I.A.410/116: "Conto de lavori d'intaglio di travertino per un arme, con bandiere, e fascie consolari fatti per servizio dell'Ecc.mo Sig.re Grand Contestabile Colonna posti in opera nella nova fontana di Roccha di Papa fatti da me Gio: Batta Grossi schultore, come sotto siegue le sud.e partite."

${ }^{106}$ Chracas, no. 6537, 2 June 1759, 20: "Per ordine della Santità di N. Sign., sono già molti giorni, che si è dato principio al lavoro delle statue, e bassi rilievi, che dalla magnanimità della Sant. Sua vogliono farsi collocare nei siti già opportunamente disposti fin da quando si fece la fabrica della nobilissima, e veramente magnifica Fontana di Trevi, per maggiore ornamento della medesima; e li virtuosi Scultori di tali opere sono li Signori Pietro Bracci, Filippo Valle, Giovanni Grossi, ed Andrea Bergondi." For Grossi's work on the Trevi, see Pinto; during the completion of the fountain under Clement XIII, Grossi was paid "per lavori fatti in riattare la scogliera, e vascone"; ibid., 277.

${ }^{107}$ In the contract of 1754 , in a space left blank for a sculptor's name, Colonna copyist Antonio del Grande filled in the words "Gio: Batta Grossi"; the same del Grande was a signed witness to the contract; AC, I.A.393/27. For a discussion of contracts in the eighteenth-century Roman building trades, see Scavizzi, 6370 .

${ }^{108}$ For an architect's duties in seventeenth-century Rome, see Pollak, 204.

${ }^{109}$ In 1732, after the fireworks for the Chinea were exploded, posts and beams (legniami) "restorono servibili e furono ripresi indietro"; see the document transcribed in Gori Sassoli, 63. The recycling of building materials occurred elsewhere and not only with ephemeral projects. Writing of the rising harbor at Ancona, the Venetian ambassador Pietro Correr learned from Vanvitelli that the latter "abbia modo di levare gran parte del legname impiegato nella descritta Tessitura, e che ne faccia uso nelle susseguenti, il che apporta considerabile risparmio"; AS, SDR 278 (letter from Rome dated 12 Nov. 1757). 
Fig. 14. Vasi, second set piece for the Chinea of 1754, etching, detail center (photo Getty Research Institute, Research Library).

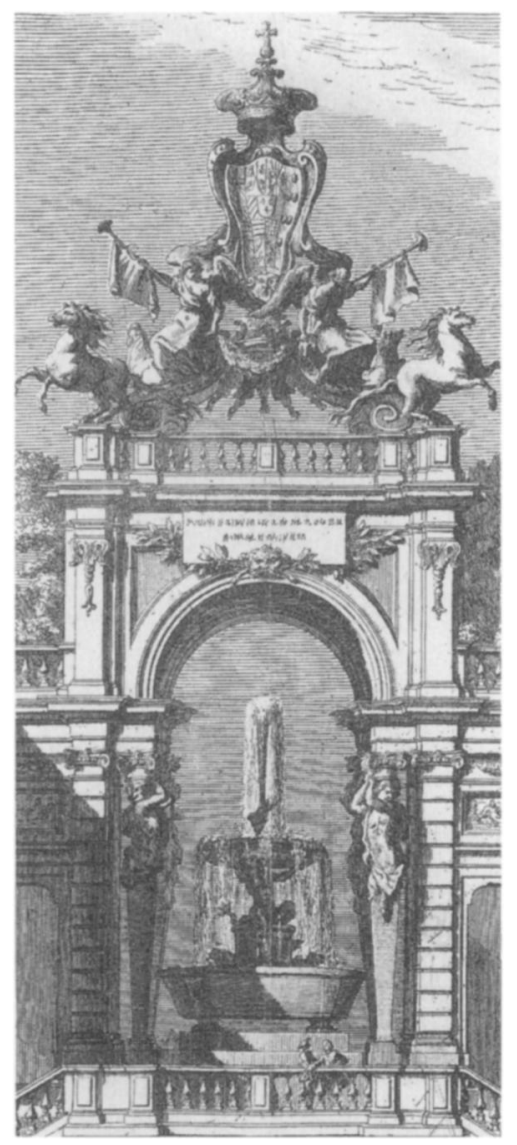

process was repeated after the second night's fireworks, with the additional requirement that the remaining material from both evenings be placed in storage, again "with every diligence and with attention." Grossi agreed to release everything that was "given, made, or put in place" by him "in favor of . . Grand Constable Don Lorenzo Colonna for service in future years." Some cellar space in the Farnese palace was used to house the frameworks; Orsini once dryly observed that the constable thus spared himself rental costs. ${ }^{110}$ Grossi transported recycled materials from their various storage places to the work site. For assistance, he had to engage a sufficient number of hired hands. He followed orders "not only from the architect, but also from the painter and the carpenter."

Once the framework supports had been assembled, Grossi had "to cover" them with "bails and little bails" ("Cerchi, e Cerchietti"). The constable provided the sculptor with metal bails, some of which may already have been in the Colonna palace or other cellar storerooms. Of various sizes, they formed internal supports for figures in gesso or papier-mâché; canvas and other types of cloth could likewise be stretched over them and subsequently supported at various angles. ${ }^{111}$ The contract specified that armatures fashioned with such bails

${ }^{110}$ For Orsini's comment, see G. Michel, 556-57.

${ }^{111}$ Pietro Pacilli, who worked on James III's catafalque, was paid "Per aver gettati di cartapeste 16. scheletri ... con ali di proporzione posto in opra sopra la sua armatura di ferro... atteggiate in diversi attitudini in atto di regere il Fanale panneggiate, e guarnite di diversi emblemi"; he also cast laurel festoons, skulls, quadriform lilies, lamps, triangular supports for lighting fixtures, and hourglasses; Kelly, 598. Cf. this payment related to obsequies 
could be used to make "clouds and reefs or other things." To join the bails, Grossi agreed to use new iron wire and to fashion closely set connections. If further reinforcement was required, he was to "put in place all the [requisite] nails." Additionally, iron tie-rods were sometimes used, as was the documented case with the horses to be seen in the etching related to the second set piece of 1754 (fig. 14). ${ }^{112}$

Grossi had to employ "good writing paper" of double thickness to cover the bails, "and not pulpy paper or waste paper" that he might otherwise buy inexpensively. ${ }^{113}$ This ensured a sturdy and smooth surface that "could support the painting." The sheets of paper were to be covered "with good paste, plentiful and without any economizing," in a process similar to the fabrication of playing cards, in which surfaces made up of glued layers of paper of different quality and composition were colored by hand with a single stencil adopted for each color. ${ }^{114}$ In 1730, Colonna household stores of wheat were used to make glue; in 1731, that staple was bought from a baker. ${ }^{115}$ Sheets of paper thus joined would be less likely to curl apart or tear. According to the architect Francesco Milizia, drawing paper meant for watercolors, maps, and illuminations was to be prepared with paste. ${ }^{116}$

Eventually Grossi's sculptural talents were put to use. The wire armatures were bent into shapes that translated the architect's renderings of figures on paper into three dimensions. The contract specified that Grossi make "clouds, rocks, and other things, and the whole quantity of figures, vases, lilies, and everything else that will be necessary for the two structures." Each of the set pieces of 1759 included a rocky base; lilies, too, the Farnese/Bourbon heraldic flower, were set on top of the flagpoles of the small pavilions flanking the central structures (figs. 1,2). Grossi was to carry out his sculptural tasks according to the pleasure and satisfaction of the architect and to follow in every way the "drawings made by the same architect," which he would "have seen and considered well." After work on the armatures had been completed, the sculptor was bound to place "heads, hands, and feet" on whatever figures the architect ordered. The contract uses the word "busts" to describe some objects that Grossi and his crew extracted from basements and storerooms. Preserved and reused, generic forms could take on new appearances and symbolic meanings with the addition of limbs,

held in Rome in the Chiesa del SS. Sudario on 22 April 1735 in suffrage for Polyxena, the second wife of Charles Emanuel II, king of Sardinia: "=X.o Giovane Scultore= / Per haver fatto il Modello di Creta d'una Testa di morto per formarla $\mathrm{p}$ il Cartapistaro, e modello di Creta simile parim.te da formarsi, e speso nel forma, e doppo formate aggiuntatoci Capelli in diversi Schersi [scudi] 10:50"; AS, LM 186 (insert in a letter from Rome of Albani to marquis d'Ormea dated 7 May 1735).

${ }^{112}$ AC, I.A.393/186: "Conto de Lavorj ad Uso di Ferraro ... =A 12 Giugno [1754]= fatto 4 Tiranti di righetta grossa Longhi p $7=$ L'Uno dà una parte fattaci un'ala à coda di rondine con buchi d inch: e dall'altra fattoci il ritengo per le legature delli fili di ferro e consegnati allo Scultore Servono per le figure delli Centauri della Machina del'foco in Piazza Farnese [scudi] 2:80/1:40; fatto altri 4 Tiranti di righetta Simile longi p81/2 L'Uno Servono per le figure dè Cavalli della Machina Sud.a [scudi] 3:40/1:70."

${ }^{113}$ In previous years, Grossi was enjoined not to use "cartaccie stampate" but "carte comprate." "Wenn man auf den Sählen gewisse Arcaden, Ehren=Tempel und dergleichen vorstellen will, so pflegt man an statt des mit Oel getränckten Papiers, welches man sonst hierzu erwehlt, weissen Atlas zu nehmen, und solchen mit Gemählden auszuzieren, wenn die Illumination magnifque aussehen soll"; von Rohr, 845 .

${ }^{114}$ For the fabrication of playing cards, see Diderot and d'Alembert, 22.2:s.v. "cartier," pls. I, vi.

${ }^{115}$ AC, I.B.42, fol. 357 right: " $E$ a di detto [16 Sept. 1730] [scudi] 12=mta in Cro à Gio Giudi Conto à Grano per pzo di r.e 2 Grano dato per fare la Colla da incartare li fuochi fatti fare da S.E. in Occas.e c.e s.a"; AC, I.B.42, fol. 301 right; " $E$ a di detto [30 June 1731] [scudi] 2:72=mta in Cro à Venanzio Crucciani Fornaro per il pzo di r.e 20 farina data per fare la Colla da incartare li fuochi Artificiali fatti in occas.e di d.a funzione."

${ }^{116} \mathrm{~F}$. Milizia, Opere (Bologna 1826-27) 2:229, quoted in Grande dizionario della lingua italiana, s.v. "carta da disegno." 
heads, and appropriate decoration. ${ }^{117}$ That the sculptor did not start from scratch each year represented a source of savings for the Colonna.

The material used for the heads, hands, feet, and "every other ornament" ("ogn'altro ornato") was papier-mâché. Grossi could charge the constable no extra for their creation, nor for any other work described explicitly or implicitly in the contract. Financial responsibility for "molds, models, paste, particular kinds of wood, iron wire, and whatever else will be necessary" fell unequivocally to the sculptor, although in 1751 he was paid for having made "several models." 118 If Grossi used straw or cloth as ballast or to build up the desired volumes in the papier-mâché sculptures, he had to procure those materials on his own. ${ }^{119}$ The list of proscriptions provides a glimpse of the day-to-day practice of sculptors who worked on ephemera. ${ }^{120}$ The use of papier-mâché was widespread, and since several surviving documents state that papiermâché was cast, molds, sometimes made of clay, existed for making garlands, lilies, and other stock elements. ${ }^{121}$ The abundant amounts of glue adopted may have served in the fashioning of three-dimensional objects, for the addition of glue to gesso increased its hardness. ${ }^{122}$

When frames, figures, or ornaments had to be lifted, lowered, turned, or carried, Grossi performed those tasks with porters and hired men at his own cost. Whether the finished works came from permanent or temporary ateliers, he and his crew had "to carry [them] and carry [them] back, as many times as will be needed," to the piazza Farnese. Some were placed near the scaffolding where the masons worked, others put aside for the second set piece. In every instance, Grossi was subject to the orders of the architect, the painter, the carpenter, and the mason. Additionally it fell to him to secure foremen, crew chiefs, and "appropriate individuals to avoid every disorder and confusion" and to ensure that work was accomplished "with every attention and with accuracy." Save for those activities that fell within the competence of the painter, the carpenter, or the mason, Grossi and his crew were obligated to carry out all tasks, "not a single one excepted," including those "not expressed" in the contract. Should he fail to comply completely with any terms set out explicitly or implicitly, the constable or the architect would judge whether others should oversee the project or bring it to completion" ("far compire l'ordinazione ò il lavoro da altri") —all at Grossi's loss, expense, and interest, "because that's the way it is and not otherwise."

Grossi was paid "the agreed and reconciled" sum of 300 scudi. Some of Grossi's extant earlier contracts confirm that the amount to be paid was negotiated each year. ${ }^{123}$ The

${ }^{117}$ For the preservation of seven sculptures used for the Chinea of 1725 , including two of river gods with the heads and hands that go with them, see Gori Sassoli, 62; for the seventeenth-century reuse of parts of set pieces, see $M$. Fagiolo dell'Arco, "La festa come 'storia sociale' del Barocco," in Fagiolo, 1:80-81. "E a di detto [8 Sept. 1730] [scudi] 30=mta in Cro à Luca Fabiani Carta pistaro per il pzo di N.o 21 Teste di Carta pista e N.o 21 para di Mano, e piedi, 21 Elmi et altro dato per Servo de fuochi, da farsi in Occas.e di d.a funz.e"; AC, I.B.42, fol. 301 left.

118 " $\mathrm{E}$ a di $=$ detto [31 Dec. 1751] [scudi] $20=\mathrm{mta}$ in cro à Gio: Batta Grossi scultore per diversi lavori fatti in Giugno pros:to in fare alcuni Modelli in servo de Fuochi artificiali"; AC, I.B.48, fol. 1046 left. For clay as a material for molds and models, see n. 111 above.

${ }^{119} \mathrm{Cf}$. petty expenses related to obsequies held on 22
April 1735 (as n. 111 above): "Per Carbone Legna Candele fiene fascine $\mathrm{\beta}$ armare le figure, et altro [scudi] 10:-_"; AS, LM 186 (insert in a letter from Rome of Albani to marquis d'Ormea dated 7 May 1735).

${ }^{120}$ For papier-mâché sculpture, see A. Contenti, Nel regno della cartapesta e del barocco: Storia della cartapesta leccese (Bari 1986) 356-58.

${ }^{121}$ For the verb "cast" (gettare), see n. 111 above.

${ }^{122}$ See N. Penny, The Materials of Sculpture (New Haven, Conn. 1993) 194.

${ }^{123}$ Some previously contracted amounts are 320 scudi in 1754 (AC, I.A.393/27); 320 in 1755 (AC, I.A.403/19); 320 in 1756 (AC, I.A.410/18); 210 in 1757 (AC, I.A.421/ 26); and 200 in 1758 (AC, I.A.427/25). 
comparative complexity of a given year's decorative program likely modified the contract price. Four barrels of wine were "for the refreshment" of the workers the sculptor employed "to execute the orders" he was given. Grossi finally obligated himself to follow the terms of the contract "according to the most ample procedures of the Reverend Apostolic Chamber, with all the usual clauses." In 1759 Grossi did receive four barrels of wine, with an extra barrel given to "young men," probably hired hands. ${ }^{124}$ The "men who worked the large frames and torsos" obtained portions of wine and bread. ${ }^{125}$ Unusually, these workers are singled out among many others, perhaps because they constituted a recognized category of labor in a city where large-scale festivals were commonplace. ${ }^{126}$ Grossi's role was pivotal and burdensome; he was saddled with many responsibilities in the weeks between 7 May and 29 June 1759. In the day-to-day records of the Colonna household, he emerges from history's shadows, having performed many of the unsung tasks numerous artists in eighteenth-century Rome regularly assumed in their search for employment.

\section{The Masons Alessandro Bernascone and Giovanni Giobbe}

On Monday, 7 May 1759, Alessandro Bernascone and Giovanni Giobbe signed a contract obliging them to construct "the whole wooden armature" ("tutto il Castello di Legname") and other things that will become necessary" for the first and second set pieces (Appendix, doc. 2). ${ }^{127}$ As was the case with Grossi, the work was to be accomplished at their own cost, with their own materials and craftsmanship, carried out according to "the conventions of the profession and to the architect's satisfaction."

The masons received 250 scudi. Contrary to the descriptive language in Grossi's contract, there are no indications that the price was negotiable. The 1759 sum, nonetheless, represented an 8.7 percent increase over the 230 scudi paid in $1758 .{ }^{128}$ As their work progressed, the masons were to be paid "from hand to hand" ("di mano in mano"), or in installments. Although there is no such clause in Grossi's case, contemporaneous contracts confirm that

124 “A Gio: B:a Grossi Scultore," 128 jugs; "Alli Giovani dello Scultore," 16 jugs; "Alli med.i," 16 jugs.

125 "All'Omini, che lavorono li fusti," 24 jugs and 48 loaves. In modern Italian, fusto del letto means bedstead; in the seventeenth century, the terms fusti di porte and fusti di finestre were also in use. For a price list of fust $i$, see Scavizzi, 127; for eighteenth-century references to fusti, see transcriptions in Pinto, 266.

${ }^{126}$ Cf. an expense of 34.425 scudi incurred "[p]er ingessatura, ed inargentatura di num. 8 Fusti di Statue de' Santi, e dorature di diversi Candelieri, e Zoccoli"; Entrata, vii.

${ }^{127}$ Giovanni Giobbe was probably an agnate relative of the Nicola Giobbe whose will is discussed in G. Brunel, "Recherches sur les débuts de Piranèse à Rome: Les frères Pagliarini et Nicola Giobbe," in Piranèse et les Français (Rome 1978) 89, who also writes (81) that Nicola, an only child, died childless. Nicola was paid 172.73 scudi in 1746 "p. il palco delli due Fuochi artificiali”; see Gori Sassoli, 63. Giovanni was probably also related to Antonio Giobbe, Nicola's father, who worked as a mason for the Chinea of 1724 , and also for that of 1730 "p. havere fatto l'armatura di Legnami"; see Gori Sassoli, 48, n. 144. Antonio was also "capo mro murat.e" for the second Chinea set piece of 1733; see J. A. Pinto, "Nicola Michetti and Ephemeral Design in Eighteenth-Century Rome," in Memoirs of the American Academy in Rome 35 (Cambridge, Mass. 1980) 310, n. 71.

${ }^{128}$ Some previously contracted amounts are 160 scudi in 1750 (AC, I.B.48, fol. 904 right); 160 in 1751, "per tanti che importa il Cottimo, cosi verbalmente stabilito" (AC, I.B.48, fol. 1046 right); 160 in 1752, "per il Cottimo cosi verbalmente stabilito delli Palchi delli due Fuochi Artificiali" (AC, I.B.48, fol. 1177 right); 180 in 1753, "per il Cottimo cosi verbalm.te stabilito delli due Palchi delle Machine de Fuochi artificiali" (AC, I.B.48, fol. 1340 left); 180 in 1754 "per il Cottimo cosi stabilito di tutti li lavori fatti in Giugno pross.to in servizio delle due Machine de Fuochi artificiali" (AC, I.B.48, fol. 1475 left); 230 scudi in 1755 (AC, I.A.403/31); 210 in 1756 (AC, I.A.410/17); 220 in 1757 (AC, I.A.421/28); and 230 in 1758 (AC, I.A.427/45). 
sculptors and masons in Rome were often paid in such a manner. ${ }^{129}$ They had to perform their work "according to the conventions of good art" and within the time prescribed by the architect; if they did not do so, the constable could have others complete the work at the masons' expense. Finally, to fulfill the terms of the contract, the masons obligated themselves, their goods, and their heirs. Quartermaster Ludovisi's annual bread account includes the masons, and butler Della Bitta records vinous disbursements to them, their apprentices, and "working masons," probably day laborers, all of whom received a somewhat greater sum of wine than did Grossi's associates, which may reflect the relative size of the two groups. ${ }^{130}$

The masons' work created the structural support hidden by sculptural and pictorial decoration. It is unclear whether Posi gave them drawings of the necessary armatures every year; the contract does state that the masons were to work "according to the drawing and orders that will be given to us by the architect" ("secondo il Disegno, ed ordinazione, che ci verrà fatto dall'Architetto"). But seeing only presentation drawings, the masons, practiced in the arts and requirements of the festival industry, could study them with an eye toward devising the requisite support, so Posi could count upon their proven skill. ${ }^{131}$

A watercolor illumination from a German manuscript of ca. 1600 depicts the making of a wooden armature for a fireworks display (fig. 15). In the center stands the mason working with his tools. Above and around him, large beams joined in a pattern similar to that used for house frames would have allowed for considerable height in the ephemeral structure, provided ample support for decoration, and enabled firework masters and others to move freely within the set piece. Plate III of Zabaglia's treatise shows how large beams were fashioned from smaller pieces of wood by means of carefully notched joints fastened with pegs, nails, or metal clamps (fig. 16). Space between vertical supports was included for the insertion of sculpted figures and painted canvas and paper. No posts were driven into the earth, so the armature could be built directly on the surface of a street, square, courtyard, or within a church without damage and the need for extra work. ${ }^{132}$ More than half a dozen drawings related to ephemera designed by Carlo Fontana exist; the most instructive in the present

${ }^{129} \mathrm{Cf}$. a contract of 20 April 1754 for the construction of a ward for ringworm patients at the hospital of S. Gallicano by masons Andrea Gino and Giorgio Termignone: "All'incontro promettono, e s'obligano i SS.ri Ministri e Sig.re Ispettore di detto Venerabile Ospedale di somministrare denaro a detti Capi mastri di mano in mano che si anderà avanzando la fabrica ed il lavoro in proporzione della quantità che sarà riconosciuta, ed approvata dall'Architetto sopradetto con farne attestato"; quoted in Scavizzi, 11618. For a contract of 1707 mandating payments "di mano in mano" to the sculptor Lorenzo Ottoni, and contracts of 1749 mandating payments "in diverse Rate" to the sculptor Giovanni Battista Maini and the stonemason Francesco Cerotti, see J. Montagu, "The Santacroce Tombs in S. Maria in Publicolis, Rome," Burlington Magazine 139 (1997) 85859.

130 “A Spesa per la Chinea per Pane dato nelli mesi di Maggio, Giugno, e Luglio del pnte anno 1759 . . . alli muratori ... in occassione . . della Chinea," no specific amount recorded. "Ad Alessandro Bernasconi, e Gio: Giobbe Mur:ri," 128 jugs; "Alli Giovani del Muratore," 32 jugs; "Alli lavoranti muratori," 16 jugs.
${ }^{131}$ Referring to the triumphal arch to be built for the possession of Pius VI, the Neapolitan royal auditor Gaetano Centomani wrote: "A V Ecc.za mi diedi l'onore di trasmettere il nuovo disegno formato da d. Fran.co Milizia, su di esso si sono fatte le opportune diligenze col Muratore, Falegname, e Pittore . . . chiamai quelli che servono la R.l Casa, e furon impiegati nell'ultimo arco. Il Muratore, e Falegname vari dubi proposero sull'intelligenza del disegno"; AS, AER 1226 (letter from Rome dated 22 Aug. 1775).

${ }^{132}$ Relazione delle cerimonie, e solennità, seguite dopo la morte del sommo pontefice Innocenzo XIII (Rome 1724) 4: "Tutta la sudetta Machina (che era alta dal pavimento della Chiesa sino alla cima palmi cento; benche in sì breve spazio di tempo architettata, ed eretta) era sostenuta da un'armatura, e tessitura di grosse travi concatenate in maniera, che la reggevano senza incassatura nel pavimento della chiesa; $\mathrm{E}$ ciò che era d'ammirazione maggiore, dentro i medesimi Candelabri si ascendeva, e discendeva commodamente per accendere i lumi, che erano mille Candele di una libra l'una, e 24. Torcie di tutta grandezza." 


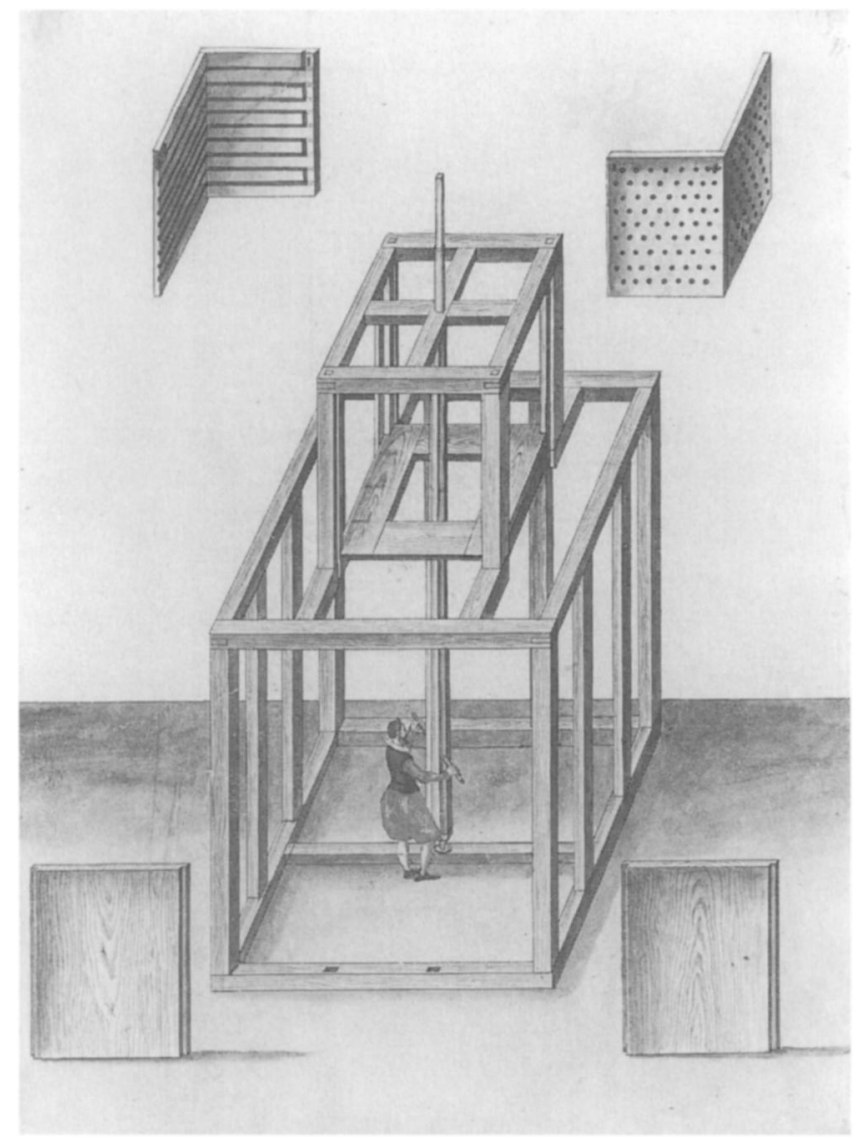

Fig. 15. Project for structural armature of a set piece. Karlsrube, Badische Landesbibliothek, Sign. HS. D 100 (photo Library).

instance relate to the transformations carried out in the church of S. Antonio de' Portoghesi for the obsequies of Peter II of Portugal on 13 September 1707. The decoration, culminating at the crossing in a baldachin surmounting a circular sepulchral urn, remained in place for a month, providing the curious ample opportunity to examine an admired ensemble. ${ }^{133}$ One drawing shows a section through the projected urn and two of four freestanding pedestals (fig. 17). With characteristic didactic clarity, Fontana uses blue wash to delineate the urn, brown for its wooden armature, and gray for the horizontal iron support on which the urn rests, in spite of its artful support by a quartet of skeletons. The wooden struts that undergird the various sculpted figures point to the essential flexibility of armatures, which could be expanded and contracted to respond to different physical situations and design concepts.

The supporting structures of set pieces for fireworks displays were much the same throughout early modern Europe, yet changes in formal, decorative, and symbolic elements transmitted an infinitely wide range of meanings in specific spatial, temporal, and functional contexts. The essential mutability of the decoration applied to armatures was made unintentionally manifest in 1745 . The French minister in Rome, monsignor Canilliac, sponsored a series of public events to celebrate the marriage of the dauphin Louis and the infanta Maria Theresa 


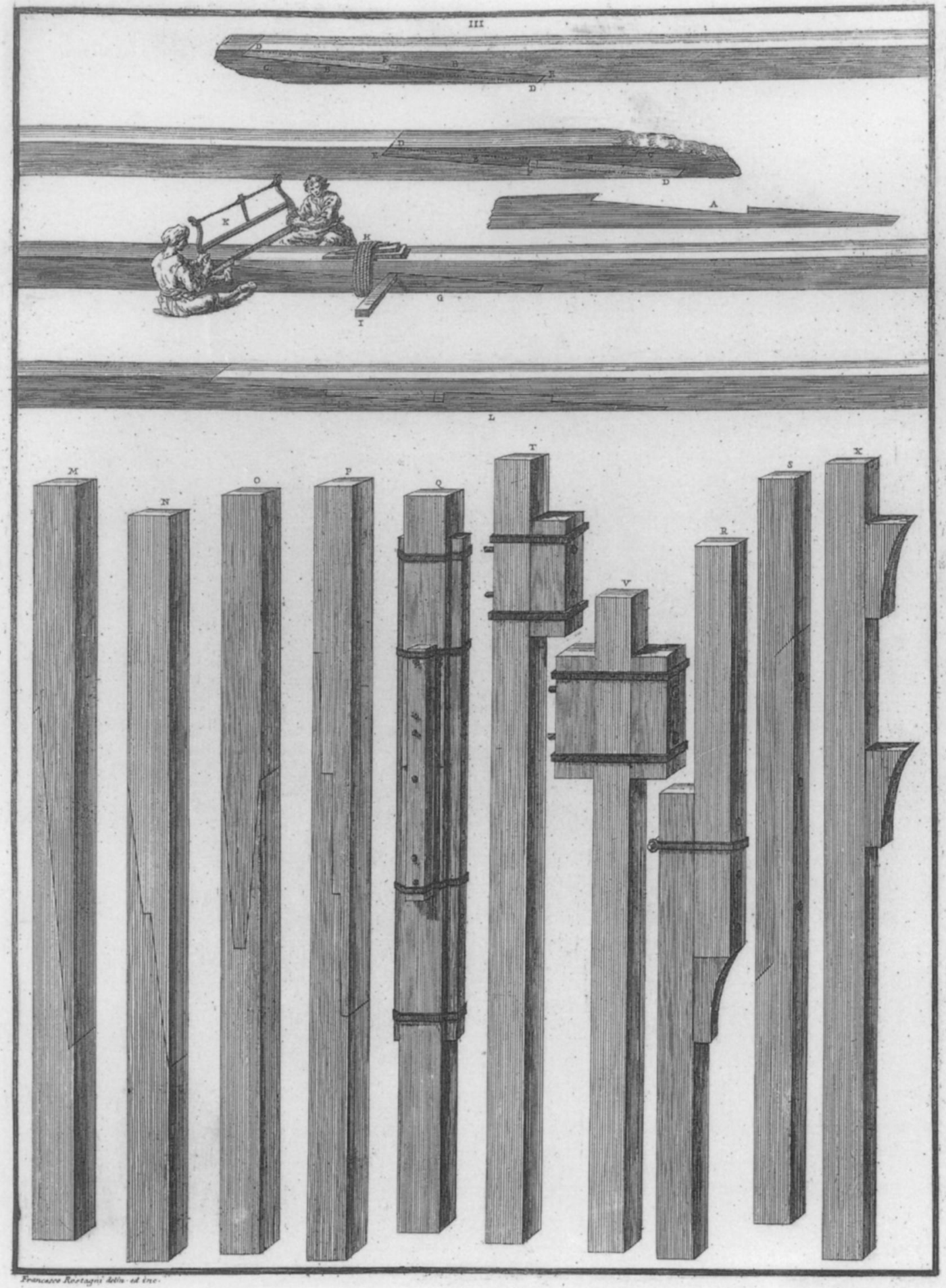

Fig. 16. Francesco Rostagni, methods for joining beams, engraving from Zabaglia, pl. III (photo Getty Research Institute, Research Library). 


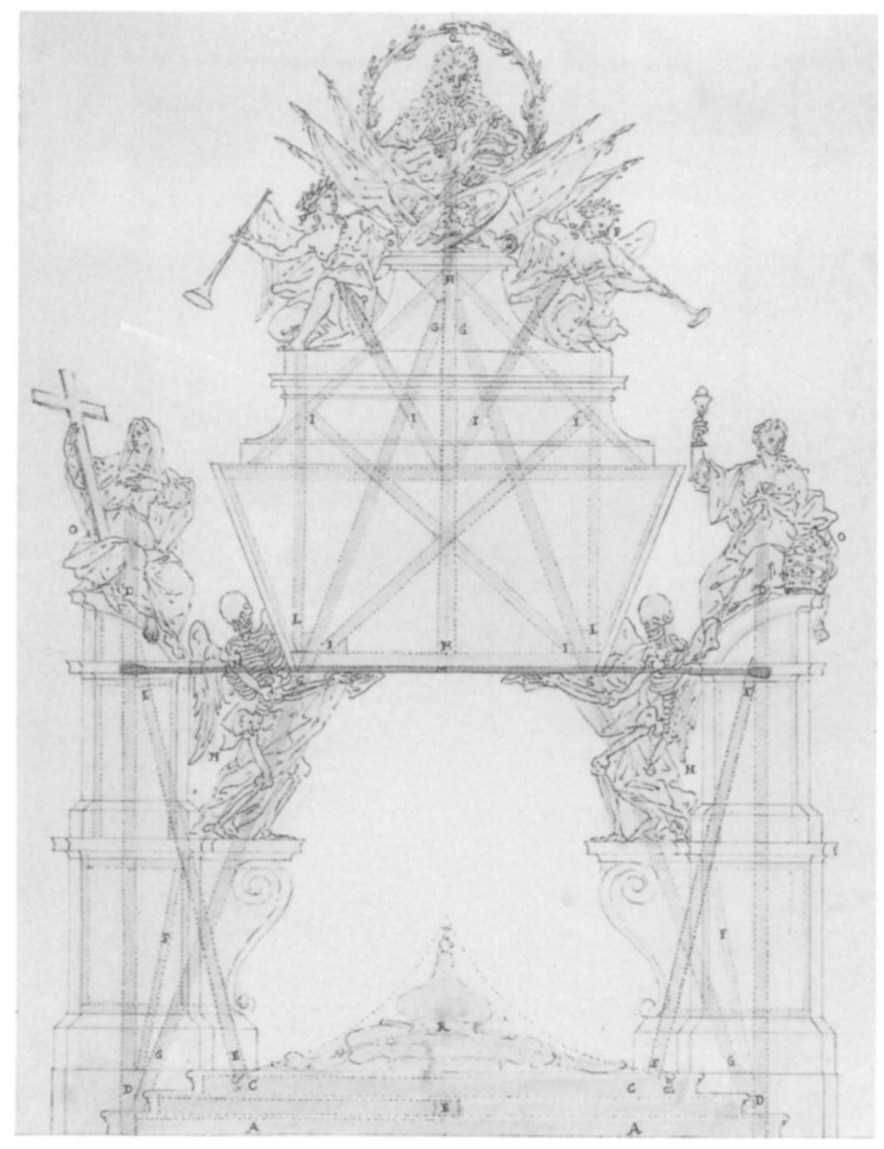

Fig. 17. Carlo Fontana, section through catafalque erected in S. Antonio de' Portoghesi, Rome, for the obsequies of Peter II of Portugal, 1707, pen, colored washes, and chalk. Windsor Castle, Royal Library 9390 (The Royal Collection (C) Her Majesty Queen Elizabeth II).

that included the raising of a festival structure designed by Giovanni Paolo Pannini. The related etching, the work of Jacques-Louis Le Lorrain, demonstrates that members of the foreign artistic community found work in the festival industry that employed so many individuals (fig. 9). Jean-François de Troy, director of the French Academy in Rome, regarded the activity of pensionnaires in that industry as an index of national gloire, and so was all the more perplexed that Canilliac had decided not to avail himself of their proven expertise, as the prince Colonna had done "for a number of years." ${ }^{134}$ Be that as it may, continuing bad weather and the start of the villa season required Canilliac to hold the structure over. ${ }^{135}$ It was not ignited "in the month of May," as is written in the inscription panel, but on Sunday, 20 June. ${ }^{36}$ That long delay left the constable no choice but to buy the armature of Canilliac's structure, for there was no time to build one to support the original design and subject (the

${ }^{134}$ Correspondance des directeurs de l'Académie de France à Rome avec les surintendants des bâtiments, ed. A. de Montaiglon and J. Guiffrey, vol. 10 (Paris 1900) 82-83. Between 1738 and 1750, pensionnaires were responsible either for the design of or the etching related to at least one set piece.

${ }^{135}$ AS, AER 1065 (letter dated 18 May 1745): "Benche il tempo si mantenesse costantemente, mà interpollatam.te piovoso, volle Sua Santità eseguire la partenza per Castel Gandolfo . . . Hanno poi continuate le belle giornate, onde molti altri sono partiti per le reciproche Villeggiature, e atteso questo spopolamento di Roma non meno che l'incostanza della stagione Mons.re di Canillach hà anche pensato di differire le allegrezze per il Matrimonio del Delfino fin dopo il ritorno della Santità Sua."

${ }^{136}$ Chracas, no. 4356, 26 June $1745,2-12$. 


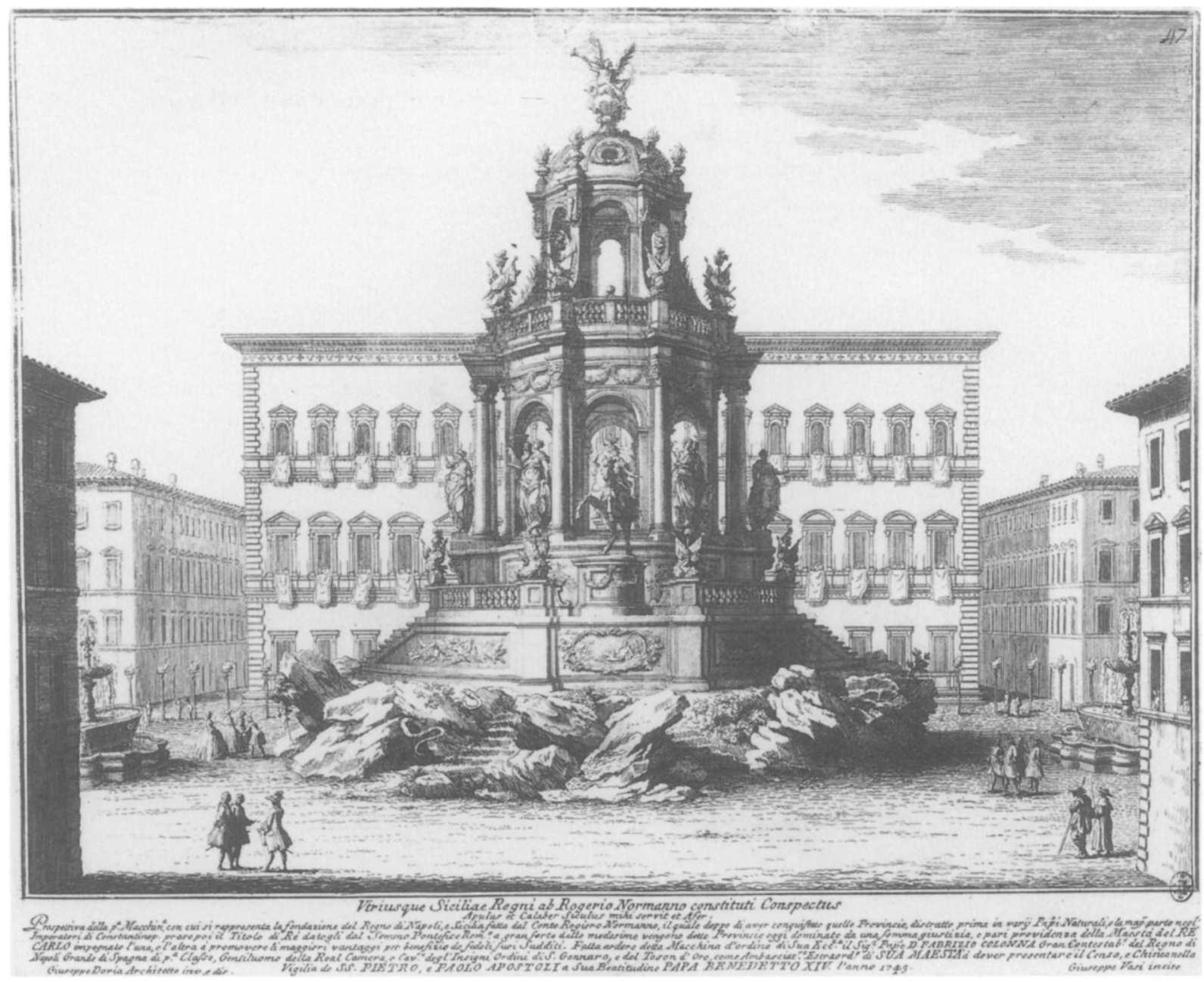

Fig. 18. Vasi (after Giuseppe Doria), first set piece for the Chinea of 1745, etching. Biblioteca Casanatense, Rome (photo courtesy of Ministero per $i$ Beni e le Attività Culturali).

twelve provinces of the Two Sicilies) of the projected first set piece. ${ }^{137}$ The mason, "master Ludovico," received 80 scudi, the smith (ferraro) Simone Moretti, 10 scudi, because for festivals that did not recur, they would have retrieved and kept the wood and hardware as part of their payment. ${ }^{138}$ Prints related to the unrealized set piece were destroyed, and another etched

137 "Io Sotto Scritto faccio fede come Mastro Ludovico: Capo Mastro Muratore principale Padrone del Lavoro di Muratore, e Castello della Macchina fatta fare dall'Eccell:mo Monsignore di Canilliac Ministro di Francia in occasione del Matrimonio del Real Delfino, in Piazza Farnese, avendo Sua Eccellenza Monsignor di Canilliac ceduto al Sig:re Contestabile Colonna il sudetto Castello per le sue Macchine di fuoco in occasione della Chinea, il Sud:o Capo Mastro, e restato d'accordo con il Sig:re Giuseppe Doria Architetto per nolo, di d.o Castello scudi novanta Mta de quali, me sotto scritto presente promise di rilassare à Mastro Simone Moretti Ferraro per nolo de
Ferramenti di detto Castello Scudi dieci mta in fede il Sud:o Sig:re Giuseppe Doria potrà liberamente ritenerli, e pagarli al sudetto Moretti queso di p:mo Luglio 1745: = / [signed] Giuseppe Panini Architetto / Mi contento che li sudetti scudi Novanta si paghino [scudi] $80=\mathrm{mta} a ̀$ Mro Paolo Sforza al quale spettano in tutto come sopra cedendo à tale effetto tutte, e singole mie raggioni perche cosi e non altrimenti che li restanti [scudi] $10=$ mta spettano à Mro Simone Moretti Ferraro per nolo come sopra / [signed] Io Ludovico rasi mano pp"; AC, I.A.332/494.

${ }^{138}$ Referring to the triumphal arch to be built for the 
copperplate with a new lettering tablet produced. ${ }^{139}$ Vasi's related etching (the first he produced for the Chinea) betrays a telltale, skeletal likeness to Le Lorrain's print (fig. 18). To be sure, in the space of eight days, the constable's équipe had to fashion decorations and a new subject (the founding of the kingdom of the Two Sicilies) that fit the contours of the used framework. In this instance, the ephemeral inconveniently lasted much too long, but a resourceful team of professionals made a virtue of necessity.

\section{The Carpenter Giuseppe Alberici}

On Tuesday, 8 May 1759, with his shaky but legible hand, the carpenter Giuseppe Alberici signed his contract for work on the Chinea set pieces (Appendix, doc. 3); stipulations of his agreement mirror those in vigor for Grossi and the masons. ${ }^{140}$ That he was the carpenter of choice may be explained by his status as the "renter of the shop placed next to the portal of the palace of His Excellency the Prince opposite the street of S. Romualdo." ${ }^{141}$ Following the designs and orders of the architect, Alberici was to carry out all carpenter's work except for the construction of the "castle of wood, which the mason is supposed to make." The distinction maintains an important division of labor between two similar spheres of activity. The masons built a load-bearing armature, whereas the carpenter's handiwork was less structural in nature. His work had to be brought to completion "according to the customs of [his] craft." He assumed all out-of-pocket expenses for materials, "including nails and production costs." The constable, on the other hand, was contractually obliged to supply "all the old wood" used previously for the Chinea, with the idea that recycled materials would reduce expense. ${ }^{142}$ On other occasions, the Colonna consigned old wood (whose quality and monetary

possession of Clement XIV, Centomani wrote: “[s]oggiunsi . . . che volendosi fare, si mandasse in Roma il disegno, secondo il quale si sarebbe trattato con gl'artisti, che a conto loro ponessero, e poi si riportassero il materiale, essendo inutilis:mo il conservarlo di non poter servire dopo 10: e più anni, per li quali si sarebbe tutto tarlato il legname"; AS, AER 1216 (letter from Rome dated 30 May 1769).

139 "E adi 27: detto [July] [scudi] 30=mta in cro ad Sudetto [Francesco Andreini], per tanti pagati à Fran:co Perziado [sic] Spagnolo per aver disegnato la pma Macchina del Fuoco Arteficiale, che non ebbe effetto"; "E adi detto [27 July] [scudi] 30=mta in cro ad Sudetto [Francesco Andreini] pagati à Micchele Sorellò Incisore de Rami per aver inciso la detta Macchina"; AC, I.B.46, fol. 1196 left; "Francesco Andreini Nostro Mro di Casa, pagate a Giovanni Petroschi Incisore de Caratteri in Rame Scudi Trentadue e [baiocchi] $45 \mathrm{mta}$, che se li fanno pagare per Saldo, ed intiera Sodisfazione di havere inciso le Lettere delli due rami fatti intagliare da Noi, e per le 2 Machine de fuochi artificiali fatti fare le 2 Sere delli 28 , e 29 del mese di Giugno pros:to, che l'Intaglio della prima Machina, non ebbe effetto, per averla fatta rimutare"; AC, I.A.323/278. "E adi 24: detto [July] [scudi] 50=mta in cro ad Sudetto [Francesco Andreini], per tanti pagati à Giuseppe Doria Architetto dell'Eccma Casa, per rimborso di tanti Spesi, e pagati in aver fatto incidere nel Rame da Giuseppe Vasi Incisore, come pure da Gio: Petroschi le lettere in detto rame del pmo Fuoco Arteficiale rappresentante le dodici Provincie del Regno"; AC, I.B.46, fol. 1196 left.

${ }^{140}$ For Alberici's work on the-Trevi Fountain in 1762 , see Pinto, 277. He died sometime before June 1763, as a bill submitted by his widow Antonia Seghetti attests; see n. 54 above.

${ }^{141}$ AC, I.B.49, fol. 200 left: "Giuseppe Alberigi Falegname Pigionante della Bottega posta accanto al Portone del Palazzo di S:E:P: incontro la strada di S: Romualdo."

${ }^{142} \mathrm{Cf}$. the following payments to the locksmith Giovanni Ascenzi on 2 July 1757: "Per aver fatto una Serr.ta nova ad'uso di Catenaccio; con sua chiave femina, e post'Inopera alla Porta del Cantinone ove rimettono il Legname della Machina del foco a Piazza Farnese [scudo] - 90/ - :50; Per aver fatto una bandella nova di verga grossa rinforzata longa p:mi 3: e conseg.ta al falegname che serve per la porta del Cantinone sud.o di peso L.e $6=$ [scudo] -45/-:30"; AC, I.A.421/166. The "theater" built in St. Peter's for the quintuple canonization of 1622 "è stato d'incredibil spesa, prima per il gran legname che si è adoperato"; Fagiolo dell'Arco, 243. Portions of structures erected for Forty Hours' festivities in S. Lorenzo in Damaso were reused, as indicated by payments for the repainting of clouds and the like; 
value were explicitly assessed) to Alberici "in credit for work accomplished and to be accomplished in service of the Most Excellent House." ${ }^{143}$ Alberici had to make "an exact and faithful accounting" of the wood he received, which, at the festival's end, he was to consign anew. For convenience' sake, to facilitate his work, and to prevent theft, special storage areas in the courtyard of the Farnese palace were regularly given over to him. ${ }^{144}$ Any other wood that Alberici adopted to carry out his tasks on the work site (whether his own, new, or used) redounded "to the benefit and favor of his Excellency, and not otherwise."

As we have already seen, Alberici was involved in outfitting the Farnese palace. He also worked to construct and complete the set pieces, even though payment documents do not specify the nature of that work. Another illumination from the German manuscript already cited shows a subsequent stage in the fashioning of a generic festival structure (fig. 19). The lower level has been covered with wooden beams that form walls; similar beams laid parallel to the ground serve as a floor. Several wooden boxes with variously perforated surfaces have been set upon the framework of the structure. Numerous thin tubes occupy the voids within the boxes and would have served as channels for the expulsion of fireworks. While the accounting records of 1759 do not make explicit mention of such constructions, their fabrication would likely have fallen within Alberici's competence and formed part of his contractual obligation to carry out "each and every task that must be done."

A bill from the ropemaker Giuseppe Tendel permits a reconstruction of some of the carpenter's activities. Tendel consigned supplies six times within ten days. For deliveries on 19 June, his bill includes the notation "to the carpenter." He identifies certain products (rope and twine among them) and the units by which they were sold (salami being the most evocative). Some purposes to which the ropes were put included fastening beams together, operating tackles and pulleys for raising and lowering heavy objects, supporting figures hoisted by means of trestles, and fashioning the trestles themselves. ${ }^{145}$

see Montagu (as n. 102) 218, n. 69, who also discusses (183-84) reused parts of triumphal arches erected for papal possessions, including one designed by Carlo Rainaldi in 1670 that inspired the same architect's high altar in the Roman church of Gesù e Maria. In 1730 Filippo Barigioni balked at the idea of paying the Chapter of St. Peter's for materials it had provided for the construction of a catafalque for Benedict XIII, "because nearly all of it was old wood"; see Kelly, 598. With the express purpose of saving money, a container (arsenale) was constructed on Farnese-Bourbon property in the Forum Romanum to store elements of the triumphal arch erected to celebrate Clement XIII's possession of the Lateran on 12 Nov. 1758. In a communication of Tanucci to Ascolese, it is made explicit "[c]he Conviene disponga che almeno due volte l'anno si rivoltino li d.i materiali perche ammassati come sono non vadino male"; AS, AER 1079 (letter from Caserta dated 17 Feb. 1759). In 1760 that task was carried out and remunerated: "Estrazione, e riposizione de Materiali dell'Arco di Campo Vaccino nel nuovo Arsenale secondo l'ordini della real Corte [scudi] 5.50"; AS, AER 1080, "Effetti Allodiali Farnesiani in Roma, e nello Stato Pontificio." For the storage in "a hayloft next to the church of S. Teodoro in the Campo Vaccino" at a rental cost of 26 scudi per annum, of a catafalque built to commemo- rate James III Stuart, see Kelly, 599. News of this catafalque built avant la mort soon reached Vanvitelli's curious ears in Naples: "Sento che si lavori al Catafalco del Re d'Inghilterra, il quale ancora per altro vive e che si faccia dal Posi"; Strazzullo, 2:521 (letter from Caserta dated 24 May 1760).

${ }^{143}$ On 8 March 1757, Alberici received "17 mezzareccie di più misure considerate per la loro qualità si stimano [scudi] 76:50," and " 16 asciadoni di più misure si stimano per la loro qualità [scudi] 16:00"; these cuttings were of walnut. Tomaso Bianchi, "Arch.o Mis.re dell'Eccma Casa Colonna," assessed the value of the wood. On 2 May, Posi gave Alberici "cinque tavoloni di Pigno che esistono nel Cortile de Pavoni del Palazzo della med.a Eccza," whose worth was assessed at 70 scudi; AC, I.A.421/25. For sizes and cuts of wood, see Zabaglia, pl. III, and explanatory text; and Scavizzi, 37.

${ }^{144}$ For a payment to a locksmith that confirms this practice, see n. 53 above.

${ }^{145}$ AC, I.A.436/66: "Conto di Robbe date ad uso di Funaro . . . in occasione delli Fochi del'Anno 1759." Goods were consigned on 18, 19, 25, 26, 27, and 28 June; 


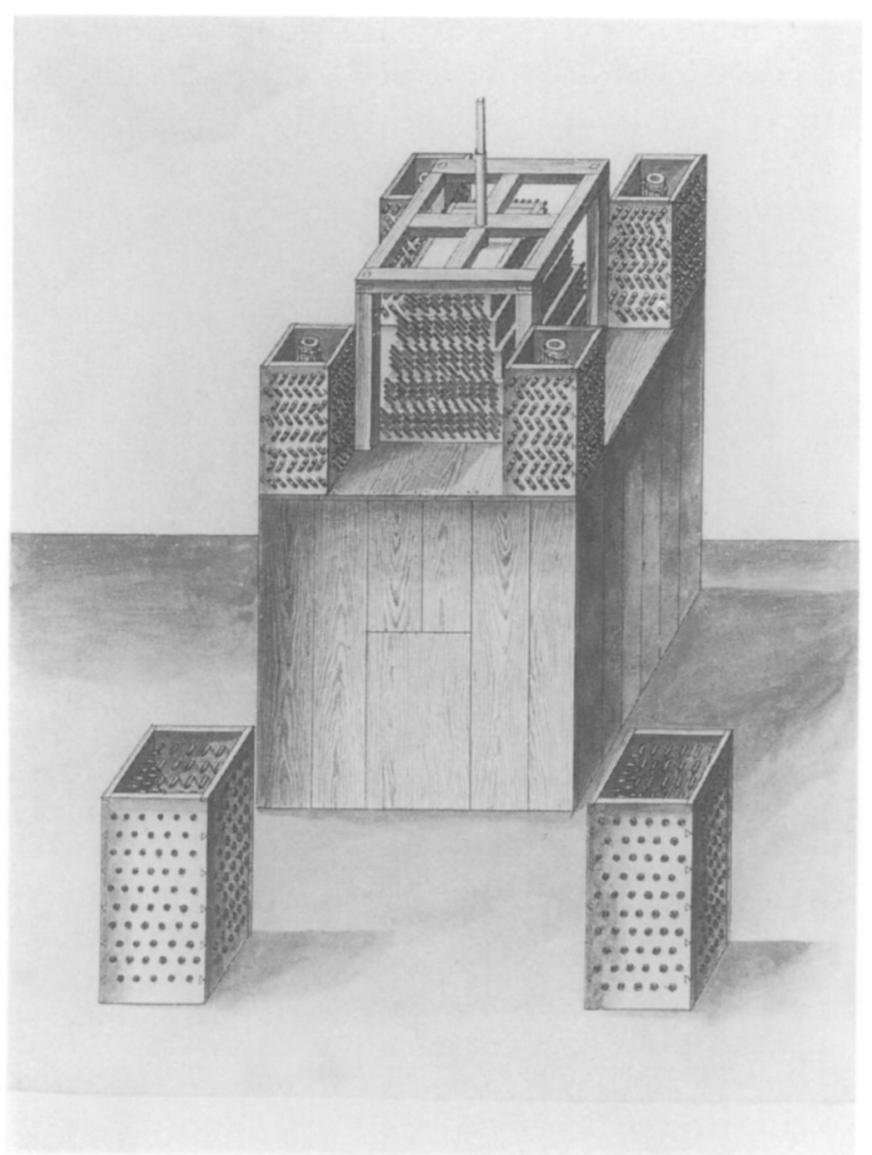

Fig. 19. Project for technical core of a set piece. Karlsrube, Badische Landesbibliothek, Sign. HS. D 100 (photo Library).

Finally, Alberici was enjoined to "give a hand to the porters every time" necessity or the architect required him to do so. As with the masons, his work had to correspond to the architect's plans and be effected in a timely fashion. Any failure on the carpenter's part to comply would make him liable for the costs involved in having someone else complete the work. At the end, Alberici was reminded that after having dismantled the structures, he was to consign the materials "to the ministers of His Excellency." Like the masons, he not only signed his name on the bottom of the contract, but bound himself, his goods, and his heirs to its terms. Alberici received 500 scudi paid in installments, the highest of any artisan involved in building the set pieces and roughly equivalent to sums paid in immediately preceding years. ${ }^{146}$

Large disbursements of wine to Alberici, his apprentices, and an indeterminate number of carpenters who worked with him indicate the importance of their efforts, whether they were manipulating their tools or just moving things around. ${ }^{147} \mathrm{~A}$ large tip given to one Matteo

asking price, 40.75 scudi, payment 32.50 . The rope types consigned were corda capezzolo, corda di canepa romanescha, corda mancina fina, corda rinforzata ("data al Sig.re Matteo Taliani"), filo da Muratore, filo di lana, sforzino, and spago. For names and functions of types of rope, see Zabaglia, pl. II, and explanatory text; and Scavizzi, 85; for types of pulleys, see Zabaglia, pl. v, and explanatory text.
${ }^{146}$ Some previously contracted amounts are 450 scudi in 1754 (AC, I.A.393/26); 450 in 1755 (AC, I.A.403/18); 500 in 1756 (AC, I.A.410/15); 450 in 1757 (AC, I.A.421/ 19 ); and 450 in 1758 (AC, I.A.427/26).

147 "A Gius.e Alberici Falegname," 24 jugs; "alli lavoranti Falegnami," 32 jugs; "alli Giovani del Falegname," 32 jugs. 
Pantera, the carpenter's "captain," also speaks to the scale of this workforce. ${ }^{148}$ Alberici received a portion of bread and collected an extra quarter-barrel of wine on 26 July, nearly one month after the festival, for "diverse efforts in service of the Chinea." ${ }^{149}$

\section{The Painters Giovanni Angelo Soccorsi and Giovanni Battista de' Rossi.}

A contract that begins with many of the legal formulae of other artists' contracts was signed on 7 May 1759 by the painters Giovanni Angelo Soccorsi and Giovanni Battista de' Rossi (Appendix, doc. 4). ${ }^{150}$ In 1741, at least, a special room in the Farnese palace was set aside for painters. ${ }^{151}$ They were responsible for painting and gilding, activities that included the preparation "of old and new canvases," and the provision of the tacks necessary to attach those canvases to their frames. ${ }^{152}$ Reused canvases were sometimes completely repainted, sometimes turned over to the unpainted side. Although it is not made explicit here, the painters did give color to gesso sculptures and enlivened architectural members with faux-marbre effects, as was typical in other festival contexts. ${ }^{153}$ The painters bore all costs involved in those tasks.

The contract explicitly required the team "to make said pictures with gesso alone and without lime." Here a technical detail reveals much about the common experiences of craftsmen and their patrons. Gesso (plaster of Paris) is an inert substance that hardens when mixed with water, yet still retains the ability to absorb it. ${ }^{154}$ Unless mixed with sand, lime will not

${ }^{148}$ AC, I.A.443/152: "A Mro Matteo Pantera Cap.no di Mro Giuseppe Alberigi faleg.e per mancia [scudi] 6:15.”

149 “Mro Gius.e Alberigi Falegname," 48 loaves; "S.re Pro darete Boccali Sedici Vino à Mro Giuseppe Alberigi Faleg.e per div.e fatiche fatte In Serv.o dell'Achinea per li Fuochi Artificiali li 26 Lug.o 1759."

\footnotetext{
${ }^{150}$ Soccorsi's work on Chinea set pieces can be traced to as early as 1724; see Gori Sassoli, 18. In 1749 Soccorsi did not have a written contract: " $E$ a di 23: Xbre [scudi] $200=m$ ta in cro à Gio: Angelo Soccorsi Pittore per il Cottimo così verbalm:te stabilito con il Sig:r Pietro Battisti Soprintendente gen:le dell'Eccma Casa d'aver dipinto insieme con Gio: Batta de Rossi altro Pittore le due Macchine de Fuochi Arteficiali fatti fare da S:E: le due sere delli 28:, e 29: Giugno"; AC, I.B.47, fol. 741 left. For Soccorsi's portraits of Charles VI and his consort, Elizabeth Christina of Brunswick, painted for a banquet held by Prince Santa Croce, imperial ambassador extraordinary to the conclave of 1740 , see Valeriani (as n. 19) 129.
}

${ }^{151}$ AS, AER 1061 (letter from Rome of Ascolese dated 27 Oct. 1741): “In secondo luogo questo Quarto è l'unico, che possa dirsi libero, e di tal Titolo specioso di Quarto non hà, che il puro nome, mentre consiste appunto in trè buone Camere, essendosi smembrata la quarta per servizio del Sig.r Ambasciadore straordinario per la Chinea, che ne fanno uso i Pittori delle Machine d'Artificio, e la quinta detta il Cucinone, che appunto può servire, e serviva di Cucina agl'Abitanti in esso Quarto, stà ora à disposizione pure di esso Sig.r Ambasciadore per i rifreschi, et altro, che abbisogna per far risplendere la di lui generosità in detta luminosa Funzione."

152 The constable assumed financial responsibility for gilding in 1754 and 1755: "à riserva però delle dorature che dovranno farsi nelle riferite due Machine, le quali non s'intendano comprese nel pnte obligo, ma dovranno pagarsi à parte oltre la d.a somma"; AC, I.A.393/28 (1754), and AC, I.A.403/20 (1755), where the clause is repeated verbatim. For bills from the same years that describe gilding applied to set pieces, see, respectively, AC, I.A.393/109, and AC, I.A.408/13. Vinous payment to de' Rossi for gilding the set pieces of 1755 exists at AC, I.A.412/206 (chit dated 31 Dec. 1755). From 1756 the painters absorbed the costs of gilding within the contracted sum.

${ }^{153} \mathrm{Cf}$. this extract from a description of the fake façade built in 1762 to celebrate Jean François Joseph de Rochechouart de Faudras's elevation to the cardinalate: "tout l'édifice étoit d'une charpente solide, peinte de la couleur des marbres les plus rares; les chapiteaux \& les bases des colonnes étoient dorées, de même que la plupart des ornemens de relief; les statues étoient formées par une petite charpente revêtue de plâtre, auquel on avoit donné la couleur \& l'éclat du marbre"; J. Richard, Description bistorique et critique de l'Italie (Paris 1766) 5:69. As gesso is absorbent and picks up dirt readily, it was necessary to paint it; see Penny (as n. 122) 194.

${ }^{154}$ For this property of plaster, see R. E. Stone, "Antico and the Development of Bronze Casting at the End of the Quattrocento," Metropolitan Museum Journal 16 (1981) 97. 
similarly harden. In comparison to plaster, slaked lime always remains a volatile and poisonous substance; under certain conditions, it can react with even atmospheric moisture to produce an immediate increase in temperature and a series of chemical reactions. ${ }^{155}$ The wellknown bleaching properties of lime made a liquid extracted from it suitable for whitewashing, yet unsuitable as a base for painted surfaces. ${ }^{156}$ The painters surely wished to stay within the fixed sum they were paid; to minimize costs and maximize profit, the painters might have used a material that would have compromised the whole project. The importance of the event, the sophisticated expectations of the viewing publics, and perhaps bitter experience made the Colonna insist upon this measure. ${ }^{157}$ The painters had to use colors "according to the norm of the drawings already shown to [them]," with the architect's "satisfaction" as the ultimate criterion for acceptance. The painters' contract explicitly named "the said Sig.re Paolo Posi Architetto," the only time his name appears in a contract from 1759. The reference to drawings suggests that on the day of signing, a team of festival professionals assembled with the architect in the Colonna palace, both to review what they had already seen and to map out efficient organizational strategies for executing the entire project. ${ }^{158}$ The painters were additionally required to "refresh with paintings" the two fountains used to disburse wine.

Soccorsi and de' Rossi agreed "to complete and perfect" their work "for the prescribed time in which the said set pieces were to be burned," and were to be paid in installments as their work progressed. If they did not complete their work on time, or if it did not please the architect, they were subject to a penalty harsher than that established in other contracts, in that they would be required to sustain the expense of having the work completed by others, but at a level higher than the contracted price. It may have been more expensive to secure other painters' services at short notice, since tasks assigned at the last minute would have been more difficult to carry out. The contract ends with legal provisions that invoke the painters' themselves, their goods, and their heirs, and a reminder that the agreed sum of 260 scudi was to include all necessary gilding, a figure that suggests that gilding was minimal in $1759 .{ }^{159}$

${ }^{155}$ For the properties of slaked lime and its adoption in making "Greek fire," see Sievernich, 6.

${ }^{156}$ For the "Rapport \& différences de la chaux \& du plâtre," see Diderot and d'Alembert, 3:s.v. "chaux."

${ }^{157}$ In 1758 , for example, a separate clause was added to the painters' contract signed on 22 May: "Con dichiarazione, che tutte le imprimiture di nove, che sopra le Tele vecchie con il gesso, e non la Calce in Fede qsto dì, et anno Sud.o"; AC, I.A.427/2.

${ }^{158}$ Variously scaled drawings were necessary to communicate designers' ideas to the many workers involved in ephemeral projects. For a payment of 20.50 scudi to Giuseppe Pozzi “for several large-scale drawings" ("per alcuni Disegni in grande") for the catafalque for James III, see Kelly, 599. Pozzi etched six plates for prints related to the Chinea set pieces of 1756, 1757, and 1758; see Gori Sassoli, 130-37; and Moore, 591. The etching related to the second set piece of 1758 is unsigned, but an extant payment document bears out Pozzi's authorship: "E a di 10=detto [July 1758] [scudi] 60=mta in cro al Sag:
Monte di Pietà pagati a Giuseppe Pozzi Incisore de Rami per aver inciso in rame le dette due Macchine da farsi in occasione di detta funzione"; AC, I.B.49, fol. 757 left.

${ }^{159}$ Some previously contracted amounts are 200 scudi in 1750 (AC, I.B.48, fol. 904 right); 225 in 1751 (AC, I.B.48, fol. 1010 left); 250 in 1752 (AC, I.B.48, fol. 1134 left); 250 in 1753 (AC, I.B.48, fol. 1267 left); 250 in 1754 (AC, I.A.393/28); 250 in 1755 (AC, I.A.403/20); 330 in 1756 (AC, I.A.410/19); 330 in 1757 (AC, I.A.421/30); and 370 in 1758 (AC, I.A.427/27). On 30 June 1753,41 scudi were paid “à Gio: Angelo Soccorsi, et Gio: Batta de Rossi Pittori per aver dorato di oro di Germania le Statue, Capitelli, e base, ed altro delle Machine di d.i Fuochi"; AC, I.B.48, fol. 1267 left; they were paid the same sum in 1754; see AC, I.B.48, fol. 1398 left. On 25 April 1760, Giovenale Zanacca and Giacomo Marini drew up a bill for "Tinture, e Dorature fatte a diversi medaglioni, Figure, Lampadari, et altro che doveano servire p. il Funerale di Sua M.ta Brittanica," which amounted to 794.675 scudi. Posi and Antonio Presi, master of the household of the Sagro Palazzo Apostolico, cut the bill to 700 scudi; see Kelly, 599. 
The lack of extensive gilding may be partially explained by a desire for cost-cutting, the outdoor location of the set pieces, and the transitory nature of the decorations themselves, which also had to be changed overnight. Few elements of the two decorative schemes remained constant, so gilding may well have been used sparingly. On the other hand, with a catafalque whose outward forms did not change, gilding could be used more liberally and would serve as an index of the esteem in which the deceased was held. That Giovanni Angeloni, who painted "all the medallions, arms, inscriptions, and other ornaments" on the catafalque for James III, received 300 scudi for his efforts suggests that the Chinea painters were paid the going rate for their work. ${ }^{160}$

Payments-in-kind of wine and bread to the painters' apprentices were equivalent to those disbursed to colleagues engaged in other Chinea-related artisanal activity, which may indicate that the teams were relatively similar in size. ${ }^{161}$ Yet the tasks assigned to these apprentices and assistants were fundamentally different. The masons and the carpenter needed assistance of many types, including muscle power for lifting and carrying beams, wielding tools, sawing wood, and the like. Remember, too, that Grossi had to provide workers to help move things around. The painters' work required less physical effort but more technical expertise. Mundane tasks (stretching canvases, preparing colors, cleaning brushes) must have fallen to their assistants.

However much forethought went into planning any festival, the weather could be neither foreseen nor controlled. At some point before Sunday, 20 May 1759, heavy rains forced the painters to redouble their efforts. ${ }^{162}$ The supporting armature and the painted decoration for the first set piece were in an advanced state of completion; since the painters signed their contract in the accountant's office on 7 May, the pictorial decoration, set in place within less than two weeks, was either produced quite quickly or perhaps begun in advance of the contract signing. ${ }^{163}$ The phrase in their contract stating that drawings had "already been shown to us" may lend support to the latter hypothesis and would demonstrate how patron and painters took the recurring nature of the Chinea for granted. In 1759 there was time enough to reconstitute the decoration; such was not the case in 1725 , when rain irretrievably ruined a set piece erected in the piazza Navona to celebrate the marriage of Louis XV and Maria Leszczynska (fig. 20). ${ }^{164}$ The painters presented a separate bill for services rendered "on

${ }^{160}$ See Kelly, 599.

161 "Alli giovani del pittore," 16 jugs; "Alli med.i," 16 jugs; "Alli giovani del pittore," 16 loaves; "Alli med.i," 16 loaves.

${ }^{162}$ Chracas, no. 6534, 26 May 1759, 4: "Per essersi dirotto il tempo da molti giorni in pioggia, continuata per più, e più ore senza interompimento, anche con freddo contrario all'avanzata staggione di Primavera, il che poteva apportar pregiudizio non solo alle Campagne, ma alla salute degl'Uomini, da questo Monsig. Patriarca de Rossi del Vicariato di Roma, e suo Distretto Vicegerente, $\& c$. si è ordinato, che in tutte le Messe si reciti la Colletta ad petendam serenitatem, come è stato eseguito, essendosi già il tempo, per grazia del Sig. Iddio, rimesso al buono." Cf. payment from 1727 "ad Antonio Bonari Fuocarolo Conto à parte per il prezzo di diverse robbe aggiunte al primo Fuoco fatto li 28: Giugno detto Anno, e spese fatte per la Pioggia seguita detto giorno ... [scudi] 20"; AC, I.B.40, fol. 323 left.

${ }^{163}$ Vinous payments dating to 27 May 1754 to Scultori e incartatori, Muratori, Falegnami, and Pittori suggest that building the set pieces had progressed apace and that the various teams worked simultaneously, some in their ateliers, not necessarily on site; AC, I.A.394/200.

${ }^{164}$ ÖS, RK 110 (letter from Rome of Alvaro Cienfuegos, imperial cardinal protector, dated 29 Sept. 1725): “[p]er la sera del terzo giorno poi era preparata una gran Machina di Fuochi artificiali in Piazza Navona; ma avendo la mattina cominciato a piovere, e continuate tutto il dì, fù preciso di ritirare sollecitam.te tutto ciò, che si è potuto, essendo però restata la Machina, e le statue distrutte dall'impeto delle acque di maniera, che non solo quella sera non si potè accendere; ma anche non si potrà senza un nuovo lavoro farla godere al 


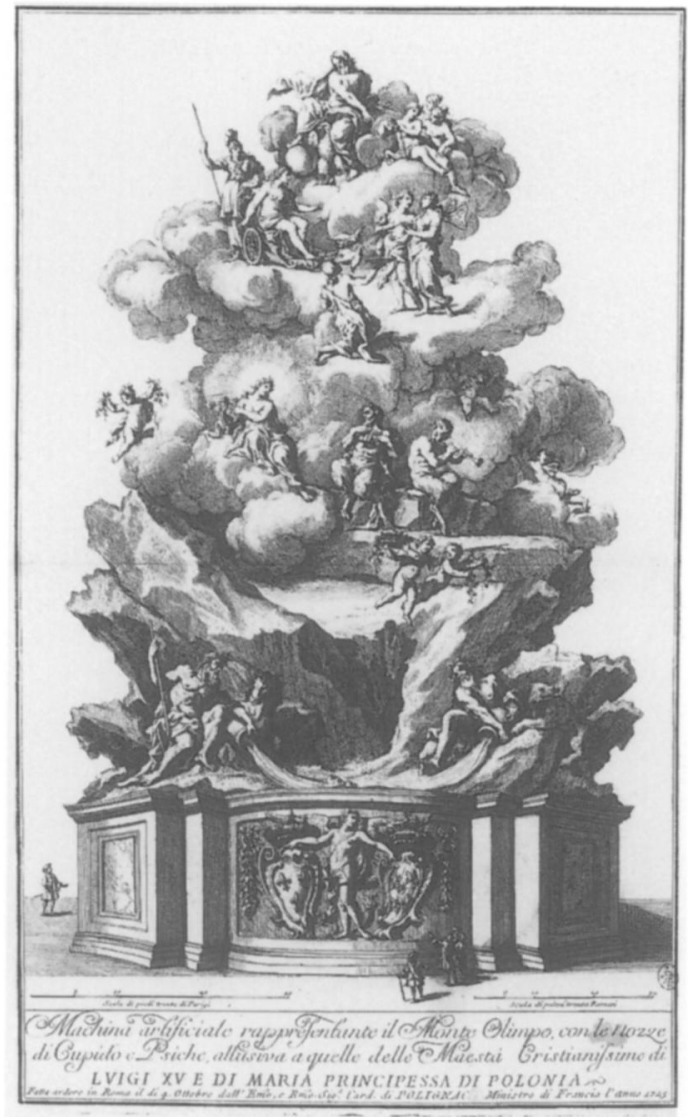

Fig. 20. Set piece erected in the Piazza Navona for the marriage of Louis XV and Maria Leszczynska, 1725, etching. Biblioteca Casanatense, Rome (photo courtesy of Ministero per $i$ Beni e le Attività Culturali).

account of the rain, which came after the structure was put up" (Appendix, doc. 5). The situation was an emergency, and emergencies were not included within the terms and agreed sum of their contract. The painters specified that they did everything according to "the orders of Sig.re Paolo Posi Architect." Their account provides information about the structure built in the piazza Farnese that cannot be gleaned from an etching alone.

The first set piece consists of an armature whose lowermost level represents the scarped base of a fortress (fig. 1). Eight large lions' heads with metal rings set in the mouths stand out in relief, six on the central block, one on each side element. These leonine figures thus pick up a decorative element of the real granite tubs in the square before the palace. Flanking the ground-level portal of the fortress are two bollards from which a heavy chain is suspended. A standing male figure guards the portal that is set in relief against the scarped base and surmounted by an escutcheon. Beyond, a flight of stairs appears to lead into the fortress.

At the second level, the tripartite division of the structure is maintained. On the left and right are small towers with scarped bases, into which round-arched entrance portals with splayed

Pubblico in appresso." The next day the remains of the ruined structure were ignited: "e non potendosi raggiustare se non con lungo, e dispendioso lavoro, dispose il sud.o Porporato, che se le desse fuoco, si mal concia come si trovava; perche differendosi più oltre, non avrebbe anche avuto chi favorisse l'invito ch'Egli fece come per la cantata. Quindi è, che Giovedì sera si accese la Machina, ed io mi portai pure a vederla in seguito dell'invito, ch'ebbi la mattina, e volli restare sino al fine, non ostante che cominciati li Fuochi sogliono molti partire"; ÖS, RK 110 (letter from Rome of Cienfuegos dated 6 Oct. 1725). 


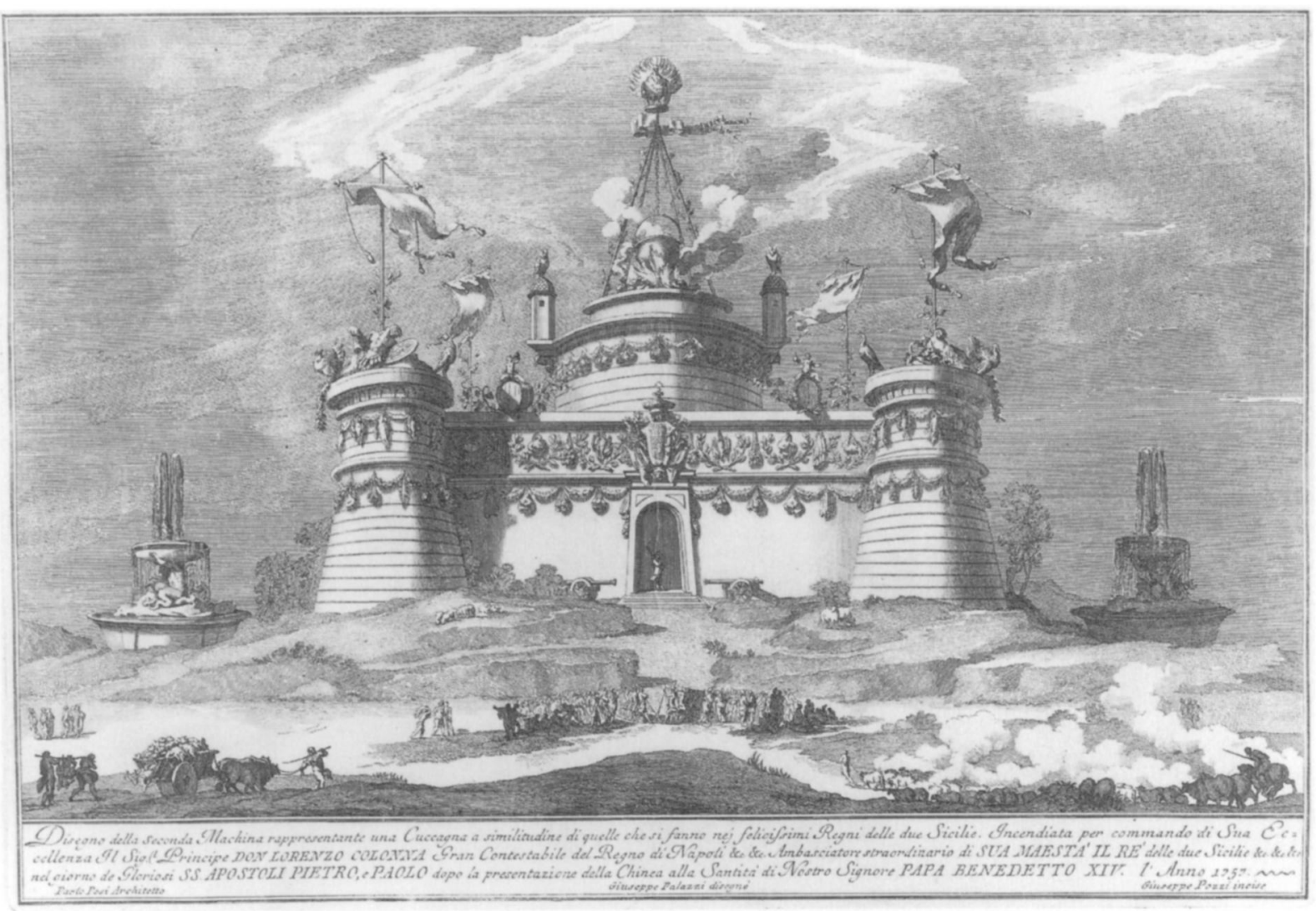

Fig. 21. Giuseppe Pozzi (after Palazzi), second set piece for the Chinea of 1757, etching. Getty Research Institute (photo Getty Research Institute, Research Library).

jambs are set. Stringcourses divide the lowermost from the middle levels, which are square in plan with crenelated rooflines. Evoking gunports, circular rings of smooth masonry stand out in relief from the rusticated blocks at both levels. From the roofs of the second level emerge cubic rooms reminiscent of sentry boxes, which are proportionally smaller than the spaces below. Into the walls at this level, round-headed niches and windows outlined in smooth stone are set. If the structure had actually been a fortress, the spaces between these sentry boxes and the crenelation of the second story would have functioned as lookout or firing platforms. On the roofs are set four flagpoles that lean toward the center and support a fleur-de-lis, the crowning element of each tower. Around these poles banners are depicted as if fluttering in the wind.

The two small towers are connected to the central fortress by bridges. The eight small sentry boxes would have defended the arched passageways below the bridges; circular in plan, they have tall slit windows, hemispherical domes, and round finials that support pennons. Rising from a cavalier on which two cannon are placed is the round fortress, with walls and window openings similar to those of the smaller flanking towers. An illegible inscription plaque hangs above the entrance portal, close to the corbels that support the parapet and slightly above the level of the round openings in the wall. Upon the parapet of the lower level, heavy masses of cloth in the shape of furled banners are artfully draped, while bristling banner poles point obliquely away from the building. The banners' function as a sign of triumph is 
confirmed by the bound and chained captives who form a bizarre human cartouche for the clock in the center, on whose face the Roman numerals I through VI are legible.

A smaller round tower emerges at the upper level. Above its stepped dome (whose outline recalls the Pantheon) rear a horse and rider, a motif that ultimately recalls the equestrian Marcus Aurelius. Yet the spirited and dramatic poses of both man and animal embody a visual idiom established in seventeenth-century Rome. Although the form and symbolism of the equestrian monument were ancient, a knowledge of more recent forays in the genre certainly enriched Posi's delineation of the group, for example, Gianlorenzo Bernini's 1670 Constantine and Agostino Cornacchini's 1725 Charlemagne, both marble reliefs in the narthex of St. Peter's. Finally, cloudlike puffs of smoke emerging from invisible sources above and from cannon set on the rocky cavalier wittily suggest a battle under way. ${ }^{165}$

Vasi used the standard conventions of his medium to fashion the image I have just described: changes in width and depth of individual lines; hatching; sharp contrasts of light and dark; linear perspective; cream-colored, rough-textured paper; and black ink number among them. Individual elements identified in the image, however, do not necessarily correspond to objects that once existed independently in the piazza Farnese. Many details in the etching may be the fruit of Vasi's creative interpretation of a drawing he received from the architect Posi or Posi's apprentice, Giuseppe Palazzi. The relationship of real objects to their representations is a problem particularly difficult to resolve in the ephemeral realm: rarely can we know with certainty which elements seen in prints were in reality three-dimensional, since two-dimensional painted surfaces with fictive imagery were extensively adopted in set pieces. Conversely, elements that seem fanciful, if not absurd, may indeed have existed. The etching related to the second set piece of 1757, whose subject is the famous cuccagna of Naples, shows a boiling pot at the summit, a detail that today one may be prone to dismiss (fig. 21). The pot, however, was real, as was the macaroni inside it, cooked by four individuals who are, significantly, absent in the etching. ${ }^{166}$ The clever contradiction of locating and fueling an open flame at the summit of a structure made exclusively of flammable materials would not have been lost on contemporary viewers.

In their extraordinary bill, the painters maintain the elusive language of art, even as they recapitulate acts of physical and mental labor with the goal of exacting payment. They describe having "remade" and "retouched" named objects, not their representations. Whatever the nature of their earlier work, the rain ruined it. The painters' extraordinary bill reveals that few areas escaped damage. Made of paper, paint, and canvas, the decorations could not withstand prolonged exposure to water. The painters begin their description at the top center of the composition and work toward the ground; the very work of repainting was probably carried out just that way, corresponding to the scaffolding still in place around the set piece. They first describe the fortress, which they had to repaint completely "where the water had done damage." If the length of the first set piece was 300 palms, the round fortress may have been more than $20 \mathrm{~m}$ in diameter. Many of the merlons "above the said fortress"

${ }^{165}$ In obsequies held in the imperial church of S. Maria dell'Anima on 19 Dec. 1705 in suffrage for Leopold I, smoking cannon were actually incense dispensers; Braham and Hager (as n. 133) 96, and fig. 187.

${ }^{166}$ AC, I.A.419/197: "Lista di Spese fatte, e danari pagati In Serv.o dell'Achinea dà presentarsi li 28
Giug.o 1757 ...@30 Giug.o... A n.o 4 huomini, che Stied.o sul fuoco della Cuccagna al Caldaro de Macaroni [scudi] 2:40." In 1756 a pound of pasta fina cost .05 scudo: "Giugno 1756 Conto delle Spese fatte da me Alberto Ludovisi . . A di 28 Giugno Lunedì . . . Sig.ri Paggi ... Pasta fina L.e 6 [baiocchi] :30"; AC, I.A.411/201. 
had to be redone or "retouched here and there, on account of the water." Merlons are absent in Vasi's etching. The banners that rest on the parapet may have obscured them, in which case it is noteworthy that the painters did not spare themselves the effort of repainting them. The painters were nonetheless paid for what they described, in a bill that architect Paolo Posi audited and signed.

The "stones" at the base of the fortress (the cavalier from which the fortress rises) had to be "dyed again." Thus the pair of firing cannon to the sides of the entrance must have been lightweight painted sculptures, or, instead, have existed not in three dimensions but as painted representations. Next the painters retouched "the bases of the two horses," "the sentry boxes of the towers with the bulls' heads," and "the eight pieces of the doors of the towers." For confirmation of many of these details, one searches Vasi's etching in vain. Only one horse is visible atop the structure, but a second may well have existed, since the structure had to be symmetrical with respect to the palace and the square. The painters mentioned bulls' heads at the level of the sentry boxes, but these are not to be found in the print. As for the towers, two doors are depicted; if the viewer puts into the etching two on the opposite sides, four are still missing. From what was set out in writing and paid for in cash, it would seem that each small tower had four doors. Without the architect's drawings or other contemporaneous documentation, it is impossible to resolve these discrepancies. "On account of the rain that trickled in from all sides," the painters had to start almost from scratch with the two bridges. The parapets all needed retouching and in some places had to be refashioned. The sentry boxes, too, required work, as did the "trophies." "Many shields" were "remade," which included not only repainting but the application of silver. (From the painters' contract, recall that the cost of any necessary gilding was included in the price paid for the whole project.) A large escutcheon hangs over the ground-floor portal, but others that would correspond to the adjective "many" are not to be seen.

Finally, the entire basement level of the structure was retouched. Twelve "giant masks of gold" were remade; perhaps these correspond to the large lions' heads. The painters restored them in chiaroscuro, a technique that would have complemented the relief effect. The use of chiaroscuro also implies that a head-on view was ideal for observing the structures-the very point of view encoded in Vasi's etching. "The rocks that go all around the structure" had to be refashioned, which confirms that the structure was decorated symmetrically. The two faces of the structure would enable all viewers within and without the palace to enjoy the designer's and artisans' handiwork. In an etching related to the second Chinea set piece of 1761, a "magnificent theater" is not what it seems (fig. 22): the orchestra and its musicians, the galleries and the spectators within them, were painted backdrops designed to deceive. Nevertheless, Posi was contractually required to make the decorative program symmetrical. ${ }^{167}$ This set piece, as the etching purports to show it, appears notably less architectonic than any of his earlier designs and does not immediately invite a reading in the round. In the theater, with which festival structures have often been compared, spectators do not walk onto the stage to examine

${ }^{167}$ AC, I.A.453/9: "E perche in uno de Disegni di dette Machine come sopra approvati si rappresenta una Scena, di Teatro con vista di Palchetti, Orchestra, Sonatori et altro, si conviene per patto espresso, che tanto nella Facciata, che riguarda il Palazzo Farnese, quanto in quella, che riguarda la Strada, che conduce alla Piazza de Pollaroli, si debba fare la stessa rappresentanza di Palchetti, con Figure ne medesimi, Orchestra con Figure rappresentanti li Sonatori, e tutt'altro dimostrato nel Disegno, tanto che si l'una, che l'altra Facciata debbano essere uniformi, con tutti quegl'Ornati che si vedono nel sopracitato Disegno, perchè così, e non altrimenti." The duc de Cröy criticized a set piece built in Paris in 1782 "for not being decorated on all four sides"; quoted trans. in Salatino, 20. 


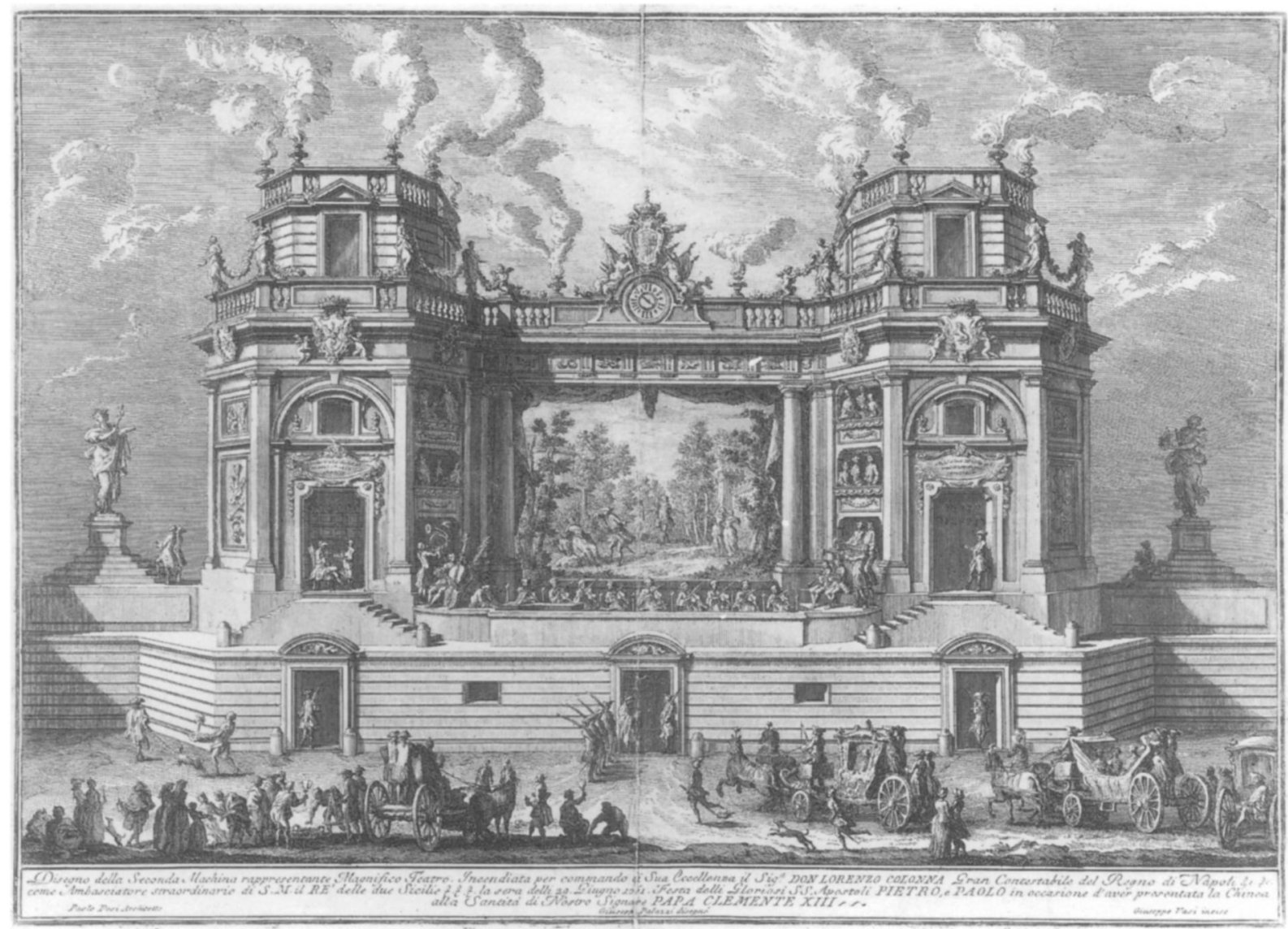

Fig. 22. Vasi (after Palazzi), second set piece for the Chinea of 1761, etching. Getty Research Institute (photo Getty Research Institute, Research Library).

the painted sets. In the piazza Farnese, which remained open to the public, designers could not count upon similar constraints. Also, the set piece could hardly turn an unadorned face toward the notables in the palace and their noble host, the constable Colonna, who stood on the balcony to signal the onset of the fireworks displays. Through the filter of the etching, the deception is all the more difficult to discern, even with a contract in hand. We do not have the same luxury as Benedict XIV had in 1745, when he, standing on the balcony of the Farnese palace and holding an elegant and expensive satin print in his hand, leisurely compared the set piece with its representation in the selfsame print (fig. 9). ${ }^{168}$

Since we know that the rocks at the base of the first set piece of 1759 were painted (and thus made of painted paper or canvas laid over an armature of metal bails), a detail in the rightmost middle ground of the etching invites skepticism. There Vasi has represented two figures (one of whom holds a staff), who sit on the rocks and seem to engage in animated conversation. It may be wrong to scrutinize Vasi's image by comparing what it depicts with the activities described in the painters' bill, for two modes of description do not have to produce equivalent results. But the painters' bill makes clear that any description of Vasi's 


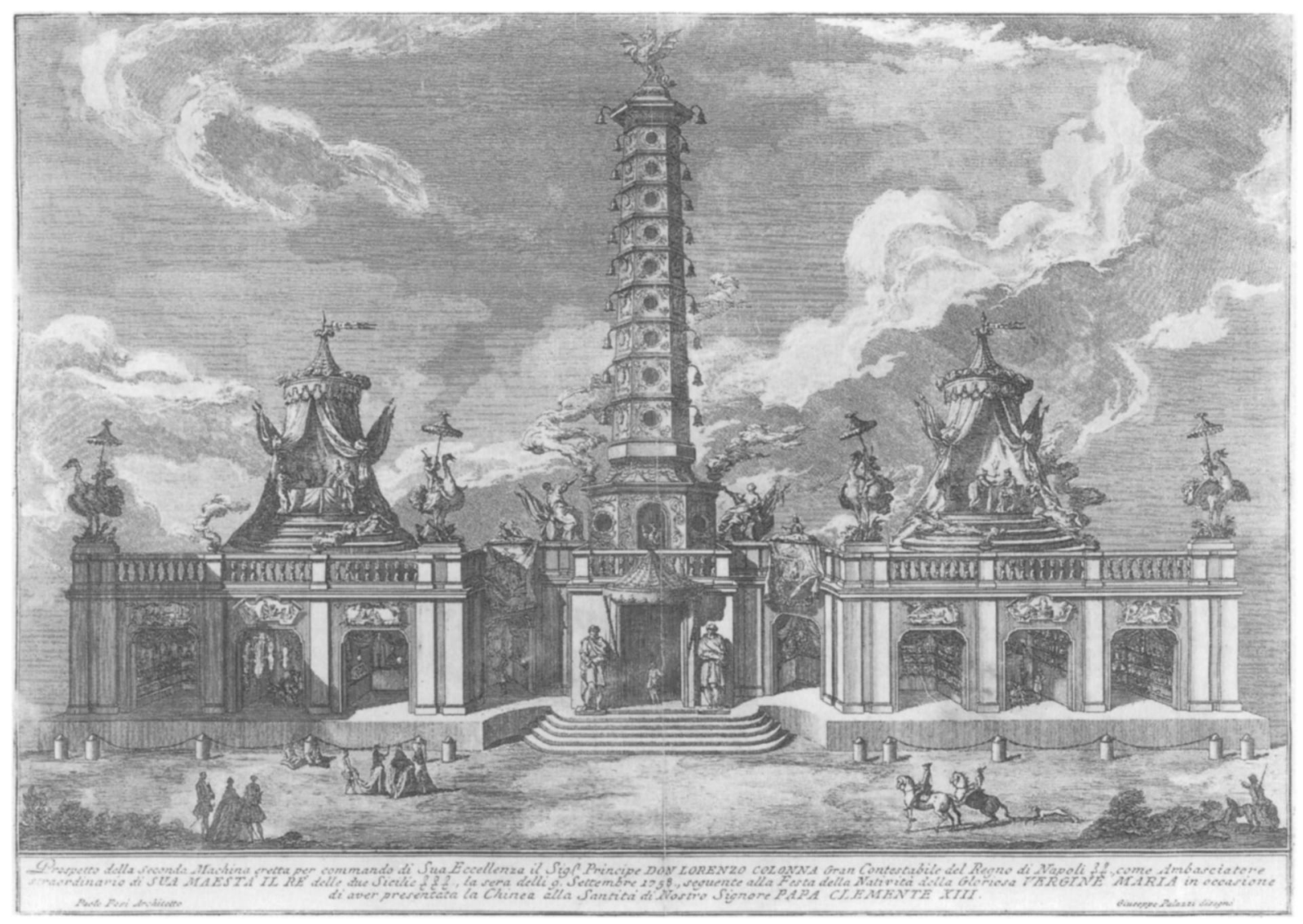

Fig. 23. Pozzi (after Palazzi), second set piece for the Chinea of 1758, etching. Getty Research Institute (photo Getty Research Institute, Research Library).

etching is ambiguous. With ephemeral structures as the subject, what is etched into the plate, inked onto the paper, and preserved for memory does not usually bear a direct relationship to designers' original ideas, for a transformative process underlies the art of printmaking.

Still, accounting records and other contemporaneous sources do confirm details that might otherwise be thought mere leaps of imagination. In 1758 a printed pamphlet description states that the second set piece represented "the tower near Nanking in China, much celebrated by travelers" (fig. 23). ${ }^{169}$ Numerous bells are suspended from the pagoda's nine pointed roofs, which Grosley called "Baroque cornices" ("corniches baroques"). ${ }^{170}$ With great excitement, the newspaper account of the same year describes the tower: "The said tower in octagonal form, completely painted in the guise of beautiful porcelain tiles, supported at its summit a winged dragon, the exclusive coat of arms of that imperial dominion; and from each of the nine levels ... not otherwise than in the real, several small gilt bells stuck out, placed in such a balance, that with every light breath of wind they rendered a happy, although dissonant

${ }^{169}$ Descrizione delle due machine di artifizio erette in Roma nella Piazza Farnese in occasione di presentarsi la Chinea (Rome 1758) [3].

${ }^{170}$ Grosley, 3:54, calls the pagoda "un grand Caffé
Chinois" and names the "Architecte Posi." Nugent, $2: 121$, translates corniches baroques as "rough cornices," which suggests that the adjective had not yet come to describe a period style for an Englishman. 
harmony. ${ }^{171}$ A note written in Posi's hand attests to the rental of ninety bronze bells, although all are not visible in the etching. ${ }^{172}$ We must keep in mind that what is visible in prints today can never exactly correspond to what the Roman populace saw.

\section{The Festival-Hangers Giuseppe and Pietro Eppe Fornari}

The same festival-hangers who altered rooms in the Farnese palace also worked outside the palace, presenting a bill that elucidates the visual character of the second set piece. ${ }^{173}$ They put into place "a large canopy of white and pink Brabant cloth over the grand Bacchanal" (fig. 2), colors that cannot be retrieved from the monochromatic etching. ${ }^{174}$ The Fornari wrapped the supports of the canopy with vine leaves and bunches of grapes fashioned from papier-mâché, "wherever the architect commanded." No scene of Bacchanalian revelry would be complete without reference to the vine and its fruit, but viewers standing in the piazza Farnese knew well that the grapes, still immature at the end of June, were the work of art, not nature. In the center of the canopied pavilion, a figure of Bacchus sits astride a wine cask, holding a goblet aloft in the left hand, a fleur-de-lis in the right.

Next came the festival-hangers' principal task, which was to place "around the whole set piece all the painted canvases so that it was impossible to recognize the first structure," an activity carried out "by order of the same architect." The workers included the cost of 4,000 pins, which cost .30 scudo per thousand. This 1.20 scudi expense was canceled by Andreini, who then reduced the asking price for labor from 6 to 3 scudi. The Colonna were not in the habit of reimbursing the cost of materials, so arguably the festival-hangers should have known better than to request such payment. The festival-hangers divided among themselves and their helpers portions of wine and bread, the former disbursed at the end of June and in July.

${ }^{171}$ Chracas, no. 6426, 16 Sept. 1758, 8. For Vanvitelli's disparaging remarks about a set piece he never saw in person but seems to have heard about before its unveiling, see Moore, 599, n. 62.

${ }^{172}$ AC, I.A.443/43: "Il Sig.re Angelo Casini á fatto N.o Novanta Campanelle di Bronzo per servizio d'una delle Machine erette nella Piazza Farnese in congiuntura della Presentazione della Chinea, le quali furono Consegnate da Mé Sottos.to Al Sig.re Gio: Batta De Rossi Pittore, e da quello al Falegname dell'Eccma Casa Colonna, ordinate le sud.te Campanelle da prendersi a Nolo per commando dell'Illmo Sig.re Pietro Battisti In Fede q.to dí 6. Novemb 1758 Dico N.o 90 Campanelle Paolo Posi Arch:o.”

${ }^{173}$ AC, I.A.443/178: "Lista di Spese fatte, e danari pagati . .. nel Mese di Luglio 1759 ...@ 28 d.o ... A Pietro Eppe Fornari Festarolo per Saldo di Suo Conto [scudi] 3," with the attached "Conto Delli Lavori fatti . . . nella Seconda Machina di fuoco artifiziale rappresentata in Pazza [sic] farnese per la festa di SS. Pietro, è Paolo per Ordine del Sig.r Pauolo Posi Architetto di S. Eccza nell'anno 1759=Per aver messo un gran Padiglione di Barbantina biancha, è rosa sopra il Gran Bacchanario, é poi in voltata tutti li pilastri di foglie verdi ed uva di carta pista in dove commandava il Sig.re Architetto Siegue per aver messo intorno a' tutta la Machina tutte tele dipinte acciò non si conoscesse più il Primo foco parimente per Ordine del d.o
Sig.re Architetto [scudi] 6:/3 - E per Spese di n.o 4: migliara di Spille à [baiocchi] 30 il Migliaro importa [scudi] 1:20 - Somma [scudi] 7:20 - Io Infratto hò ricevuto . . . Scudi Trè mta per Saldo del pnte Conto li 28 lug.o 1759 [scudi] 3 mta - [signed] Pietro Eppe Fornari mpa."

${ }^{174}$ A figure that went intrinsically with festivity, Bacchus loomed large in the consciousness of eighteenth-century Rome at all levels of society. For example, during carnival celebrations in 1756, "ciascuno ... ha potuto finalmente dilettarsi nella gran strada del Corso, non meno delle Corse de Barberi, che delle mascherate, le quali, tanto a piedi, quanto su de Cocchi in diverse curiose rappresentanze vi hanno fatto con abiti ricchissimi un continuo passeggio; essendo però stata più delle altre dilettevole, ed universalmente applaudita, quella del Trionfo di Bacco, che nell'ultimo giorno si vidde molto propriamente sopra di un Carro nobilmente ornato, e tirato da 4. Cavalli in fila"; Chracas, no. 6030, 6 March 1756, 8-9. Five months later, for a much more limited audience, "[c]on grande applauso fu tenuta . . . nel Quirinale l'Accademia di Storia Romana alla presenza di Sua Santità, e coll'intervento di Sua Eccellenza il Sig. D. Lorenzo Colonna Gran Contestabile Protettore, e di molta Prelatura, Religiosi, e persone erudite; avendovi recitato la dissertazione l'Accademico Sig. Canonico Gio: Amedeo Ricci, ed il suo raggionamento fu delle antiche Feste baccanali"; Chracas, no. 6096, 7 Aug. 1756, 8-9. 
Their bill was posted on 28 July; thus the extraordinary disbursement of wine may correspond to Andreini's realization that the festival-hangers had not been fully compensated. ${ }^{175}$

That painted canvases were placed around this armature confirms widespread practice. Although the goal was to mask one structure in order to reveal a new one, the underlying support remained the same and is legible in the etchings (figs. 1,2). A tripartite division of the architectural composition obtains in both, with a large central block linked by bridges to flanking smaller units. The changes effected by flat paintings stretched within frames are remarkable. The scarped walls of defensive structures are transformed into simple, slightly canted surfaces. The basement level of the second set piece seems pierced by windows located above the level of the lions' heads in the first. Fortress forms and symbolism are replaced by a scene of rustic relaxation: men and women move toward or sit around a table where a musician plays a stringed instrument. In the center Bacchus presides as tutelary deity. The round fortress of the first set piece (vaguely reminiscent of the Castel S. Angelo) was set upon a rocky cavalier, whereas in the second, that decorative element cedes to a grassy knoll shaded by the canopy suspended from the trees. Cubic pavilions (similar, for example, to those at the Villa Lante at Bagnaia) are surmounted here not by sentry boxes but by raised musicians' platforms; trumpeters and one French horn player are visible on the right. According to the evidence that the etching appears to provide, the only decorative elements carried from the first structure to the second are the flags that flutter over the side pavilions; even they, however, are supported differently.

The "fortress" might seem capacious enough to enclose, cocoonlike, the tableau of the second set piece, but the extraordinary festival-hangers' contract proves that paintings were the vehicles of this thorough alteration. ${ }^{176} \mathrm{How}$ the resolutely three-dimensional character of the armature and the flat images attached to them actually functioned in visual and experiential terms are the most elusive elements to reconstruct. The etching does not and cannot mirror every detail preserved in accounting records: in the latter the transfer of real goods and services structured expectations, whereas in the former, the creation of a pleasant, convincing illusion was the aim.

Plate IX of Zabaglia's treatise depicts a nonspecific urban setting with, on the left, overlapping fragments of a church façade, tall noble palaces, and a shorter housing block arranged in a perspective view not unlike a painted flat for the stage (fig. 24). Ladders set against the massive two-story loggia in the foreground provide an arterial network for acrobatic human activity. The explanatory text emphasizes how "truly extraordinary" the festival-hangers' practice of extending ladders was, for it enabled them "to work daringly-in uncomfortable, unseemly, and dangerous positions-to effect whatever type of sumptuous decoration

175 "Alli festaroli," 12 jugs; "Alli med.i," 6 jugs; "Alli festaroli," 24 loaves; "S.re Pro darete Boccali Dodici Vino alli Festaroli per beveraggio dell'Achinea li 28 Lug.o 1759."

${ }^{176}$ Elements of one structure could be enclosed within another, as occurred in 1637, when Manuel de Moura, second marquis of Castel Rodrigo and Spanish plenipotentiary in Rome, celebrated the election of Ferdinand III as king of the Romans (i.e., and unusually, heir to the Holy Roman Empire). In front of the Palazzo di Spagna stood a fortresslike structure that, after the explosion of a series of fireworks, decomposed to reveal an equestrian statue of the newly elected monarch, which in turn propelled itself into the embassy; see A. Villon-Lechner, "Sprühende Tauben und flammende Bauten. Das römische Feuerwerk als Friedensfest und Glaubenspropagandatheater," in Die schöne Kunst der Verschwendung: Fest und Feuerwerk in der europäischen Geschichte, ed. G. Kohler (Zurich 1988) 26-27. For illustrations of related etchings by Claude Lorrain, see Sievernich, 7576, figs. 6/20.1-6; and Fagiolo dell'Arco, 292-94. 


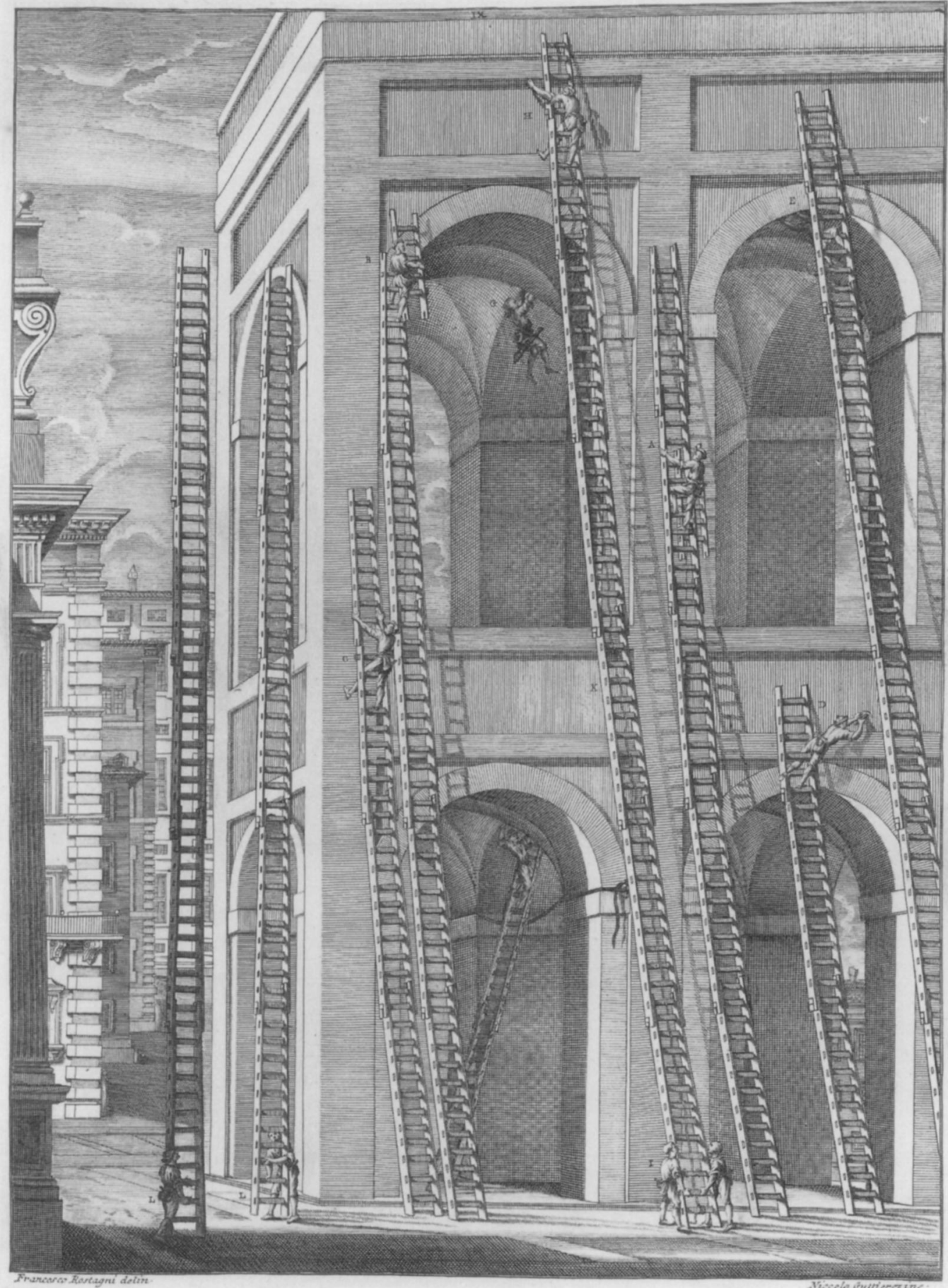

Fig. 24. Niccola Guttierez (after Rostagni), festival-bangers working on ladders, engraving from Zabaglia, pl. IX (photo Getty Research Institute, Research Library). 
with boldness and speed." To the right, two festival-hangers at letters D and E each thread a leg around a rung of a ladder. Having thus freed their waists, torsos, and arms to move as needed, they stretch themselves into contorted positions at daredevil heights. At letter $\mathrm{H}$ a worker is shown pushing the ladder away from the wall with one leg and simultaneously moving his hands along that surface. With feet planted firmly on the ground, two colleagues follow the lead of the one above, carrying him and the ladder in a synchronized balance. The Fornari attached the adjective "long" to the noun "ladders" on more than one occasion, no doubt to reinforce an image of difficult, risky work. ${ }^{177}$

\section{FOUNTAINS}

During the Chinea, two fountains were set up to distribute free wine to the public at fixed hours. ${ }^{178}$ Attached to the façade of the Farnese palace and drawing the excited attention of crowds of people, fountains are visible in Vasi's commemorative etching (fig. 6). These devices, which the painters contracted to work on the Chinea set pieces were bound "to refresh with painting," were at times stored in ground-floor rooms at the embassy or in the "Courtyard of the Peacocks" at the Colonna palace; the latter location necessitated the cumbersome transport of the objects to the site of festivities, to say nothing of the wine. ${ }^{179}$ Four men called "hunchbacks" (gobbi) tended the fountains. Identified explicitly in accounting records as members of "the outside staff," they received cash and in-kind payments. ${ }^{180}$ These figures can be located in etchings related to Chinea set pieces. From 1722 to 1733 , fireworks structures for the Chinea were erected in the piazza SS. Apostoli, the square visible in an etching related to the first set piece of 1722 (fig. 25). Individual elements in the image are explained in a key at the bottom; number 9 locates a "fountain where white and red wine were dispensed." In an etching related to the first set piece of 1731 , fountains and hunchbacks are also clearly depicted (fig. 26). Prominently displaying the Colonna coat of arms, the former were large, freestanding polygonal structures whose scarped walls recall fortifications. A closed circulation system enabled the wine to emerge in jets and streams. Standing high on top of the fountains, the hunchbacks used large ladles to pour wine from the collecting basin into receptacles that people held upward. Even when the fountains were attached to the façade of the Farnese palace, the hunchbacks not only distributed wine but ensured that as many individuals as possible shared the bounty.

${ }^{177}$ AC, I.A.417/227: "Conto Delli Lavori fatti . . . nelle due Machine rappresentate nella Piazza Farnese per la festa di S. Pietro è Pauolo ... nell'anno 1756 / Pma per aver messo tutte le tele in dove commandava il Sig.re Pauolo posi Architetto di Sua Eccza con sei Ommeni con scale Lunghe"; emphasis in text.

${ }^{178}$ Chracas, no. 8070, 1 July 1769, 22: "Per le sopradette feste publiche preparate a farsi per la presentazione della Chinea, eranvi state erette nella piazza Farnese due fontane di generoso vino, per godimento della plebe, appoggiate al Regio Palazzo, che durarono sino alla notte del Giovedì a gettar vino nelle ore destinate." In 1726, "in tutto quel giorno, come si fece per la metà del giorno antecedente, Vino di più sorti, [fu] gettato da più parti di una artificiale Fontana"; Chracas, no. 1109, 9 Sept. 1724,12 . That wine was available only half the day on
28 June may correspond to its having been a Friday, a day of fasting. In 1738 wine was available "tutte due li giorni dalle ore 21 fino alle 2 di Notte"; Gori Sassoli, 63.

${ }^{179}$ For transporting the fountains of wine, see n. 45 above. A document in the Colonna archive specifies tasks that have to be made explicit in artisans' contracts, including the construction of a "Steccato terreno dove si lavorano li Rinfreschi, e si conserva il Vino per le Fontane"; as transcribed in Gori Sassoli, 64.

${ }^{180}$ Wine and bread accounts name the gobbi Antonio de Vecchi, Giovanale Grispoldi, Antonio Cenci, and Domenico Bazzichalupi; each received 2 jugs and 4 loaves. Each man also received 1.20 scudi; AC, I.A.443/ 152. 


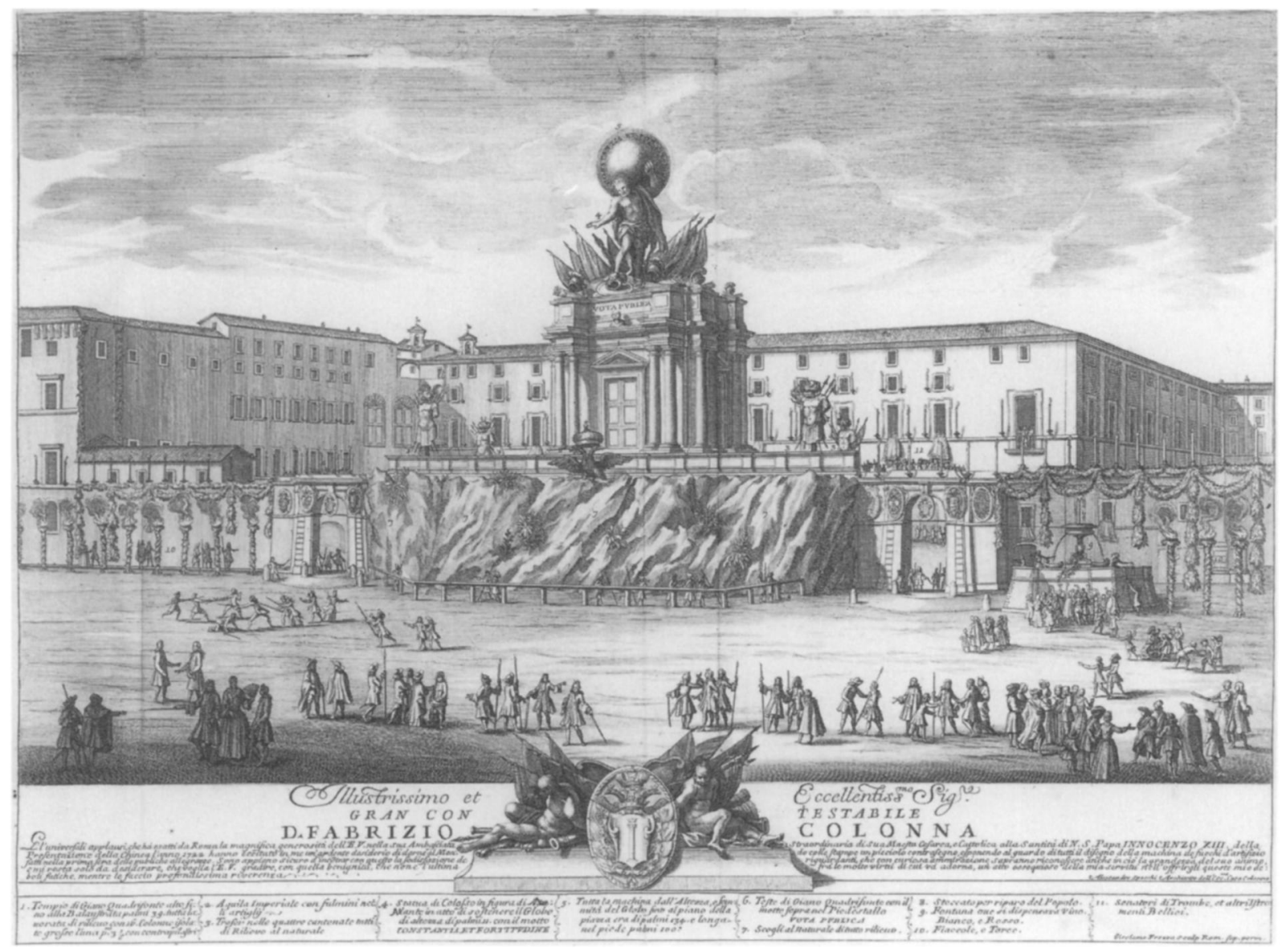

Fig. 25. Girolamo Frezza, first set piece for the Chinea of 1722, etching. Getty Research Institute (photo Getty Research Institute, Research Library).

The fountains for wine in 1759 were of the same type as those represented in Vasi's commemorative etching (fig. 8). Set between the fourth and fifth windows to the left and right of the portal, they consist of large, tiered substructures that rest on the ground, reaching up to the level of the stringcourse that unites the windowsills. Their upper tiers appear to be pierced by balusters. Between the same windows are suspended two plaques with elaborate curving edges and mask forms from which wine was expelled; basins set beneath the spigots collected the liquid. One can just make out the figures of four hunchbacks who stand in pairs on the upper tier of the substructures, distributing wine to large groups of people gathered around the fountains. That this detail of Vasi's etching conformed to a real situation in 1756 (and to standard practice) is confirmed by disbursements to four hunchbacks, two of whom also worked in 1759. ${ }^{181}$ Likewise, in June 1759, butler Della Bitta disbursed twenty-eight barrels of wine for the fountains in the piazza Farnese, a sum that represented 9.61 percent of all

${ }^{181}$ Bartolomeo d'Amici, Giovanale Grispoldi, Giovanni Fioccho, and Antonio de' Vecchi each received 2 jugs and 4 loaves, the same amounts as the team of 1759 . Grispoldi and de' Vecchi served every year between 1756 and 1759; for 1756, see AC, I.A.412/206 (wine), and AC, I.A.411/204 (bread); for 1757, see AC, I.A.422/172 (wine), and AC, I.A.422/171 (bread); for 1758, see AC, I.A.428/155 (wine), and AC, I.A.428/154 (bread). 


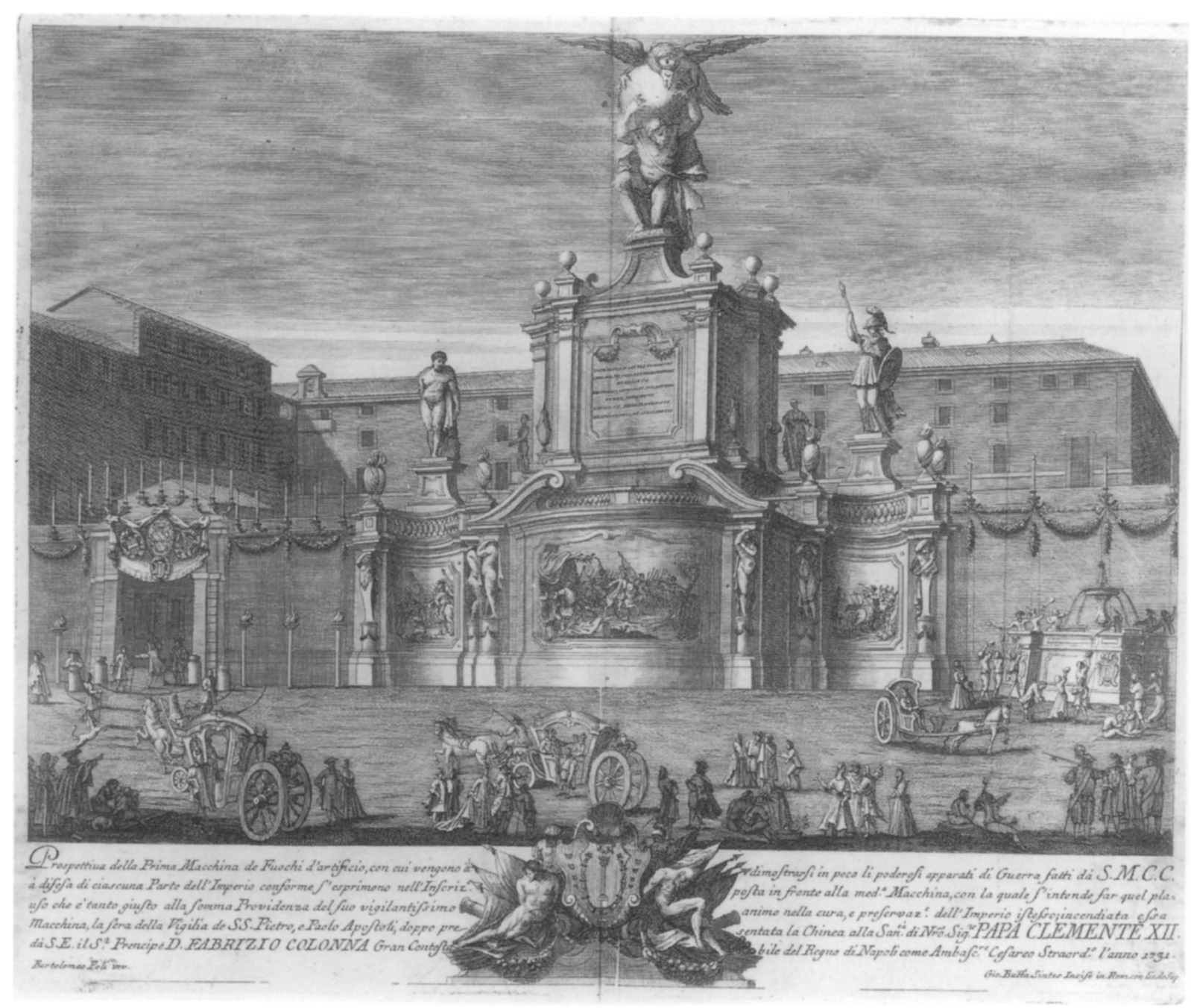

Fig. 26. Giovanni Battista Sintes (after Bartolomeo Poli), first set piece for the Chinea of 1731, etching. Getty Research Institute (photo Getty Research Institute, Research Library).

wine disbursed that month. ${ }^{182}$ Accounting records name a steward (canevaro) and a head butler (cantiniere); the latter received in-kind payments for services that were nothing short of Herculean, for he had to account for both the twenty-eight barrels of wine (disbursed over a fixed and brief period of time) and numerous small receipts presented for redemption by many individual bearers over time. ${ }^{183}$

The bills of the tinsmith Carlo Giuseppe Bassetti describe how fountains and waterworks were made to function. ${ }^{184}$ In 1759 his efforts can be divided into four categories: the fountains

182 "Barili Ventotto Vino Sud.o [di Cantina] dato li 2 giorni delli 28, e 29 di d:o mese di Giugno per le due Fontane del Vino, in occassione della Funzione della Chinea del pnte anno." Total amount distributed in June, 291:31:3 (i.e., 291 barili, 31 boccali, 3 fogliette); cash value of Chinea disbursement, 56 scudi. With one barrel equivalent to 58.34 liters, 28 barrels represented a dis- bursement of 1,633.52 liters, according to the conversion standard cited in n. 209 below.

183 "Al Cantiniere," 12 jugs; "Al Cantiniere di S. Eccza," 24 loaves.

${ }^{184}$ For the fountains of wine, asking price, 9.00 scudi, 
of wine; the fountain of Bacchus; slight modifications to the permanent fountains in the piazza Farnese; and payments to additional workers. For the fountains of wine, Bassetti provided three and a half sections of new lead pipe, which he cut into pieces of different size, and two new spigots, the latter serving "to control [the amount of] wine." The cost of these materials reflected the price of rental, not purchase. Bassetti cut one length of new pipe into two equal pieces, the other into four pieces, and made four solderings. After they had been "bent and twisted to follow the wall and the window frames [telari]," Bassetti affixed two tubes to the exterior of the palace. Three hooks were put in place on each side to ensure a secure support. To the pipe ends that were inserted into the barrels of wine, Bassetti attached two "pockets of bolting cloth" ("due Sacocie di staminia"). These were meant to keep out the dregs, so that they would not enter the pipes and clog "the veils and jets" ("vele e zampilli") of the fountains. Just as water became a sculpted object in the magnificent fountains of baroque Rome, so, too, did streams of wine create aesthetic effects.

The plumber then used hemp rope, putty, and fire-heated iron wedges to make fast the pipes at the points where they entered the barrels; at the other end of the pipes were the spigots. Behind the two fountain masks, Bassetti fastened the pipes with nails and tied them tight; hemp rope, putty, and solderings of tin ensured that the pipes would not move. $\mathrm{He}$ inserted "veils" into the mouths of the fountain masks, securing them with hemp rope and putty. In addition, from his own lead he made four jets, each half a palm in length $(.11 \mathrm{~m})$, and four small pieces of tubing. After these pieces were soldered together, he made two new jets for each fountain, set into holes in the bottom of two wine basins, which expelled wine in streams to larger basins set below. Some system of recycling was in place here, since the amount of wine disbursed was finite. The fountain of Bacchus and the fountains of wine at the embassy neatly linked conceptual and experiential elements of the festival. Onlookers could not only observe the ephemeral structure, admire its appearance, and comment upon what it represented, but could also slake whatever thirst for wine the illusory scene before them might have aroused.

The fountain of Bacchus constituted the central decorative group of the second set piece (fig. 2), thus water contributed to the change in iconography, and waterworks were, in fact, housed within the armature. Bassetti records the work of two men who worked two halfdays, "helping at all the above fountains both of wine and of water, up to two o'clock at night," or two hours after sundown in Roman time.

Fresh water was brought to the piazza Farnese from two sources. Two conduits of the Acqua Vergine led to different points in the palace compound; one supplied the kitchen and staff dining room on the ground floor (fig. 4, R, G), the other led "to the fountain of the small garden of [S. Maria dell'Orazione e della Morte]." One branch of a conduit that led from the Acqua Paola through Trastevere and thence under the roadbed of the Ponte Sisto fed the Fontana del Mascherone on the via Giulia and the two colossal Egyptian granite tubs, once in the Baths of Caracalla, that had served as fountains in the piazza Farnese since 1626, providing a welcome sense of scale; a reservoir and various distribution points on both sides of the Tiber are located in a plan by Pietro Maria Boschi preserved in Naples (fig. 27). ${ }^{185}$ To

payment, 5.40; for the fountain of Bacchus, asking price, 18.90 , payment, 10.55 ; for adjustments to permanent fountains, asking price, 1.40 , payment, .85 . "E. per lasistenza di due meze giornate di due ma:ri perasistere atutte leSud.e fontane si delvino come delaqua Sino alle ore due di notte," asking price, .60, payment, .40; AC, I.A.442/186.

${ }^{185}$ For the history of the tubs and the creation of the fountains, see C. Pietrangeli, Guide Rionali di Roma. 


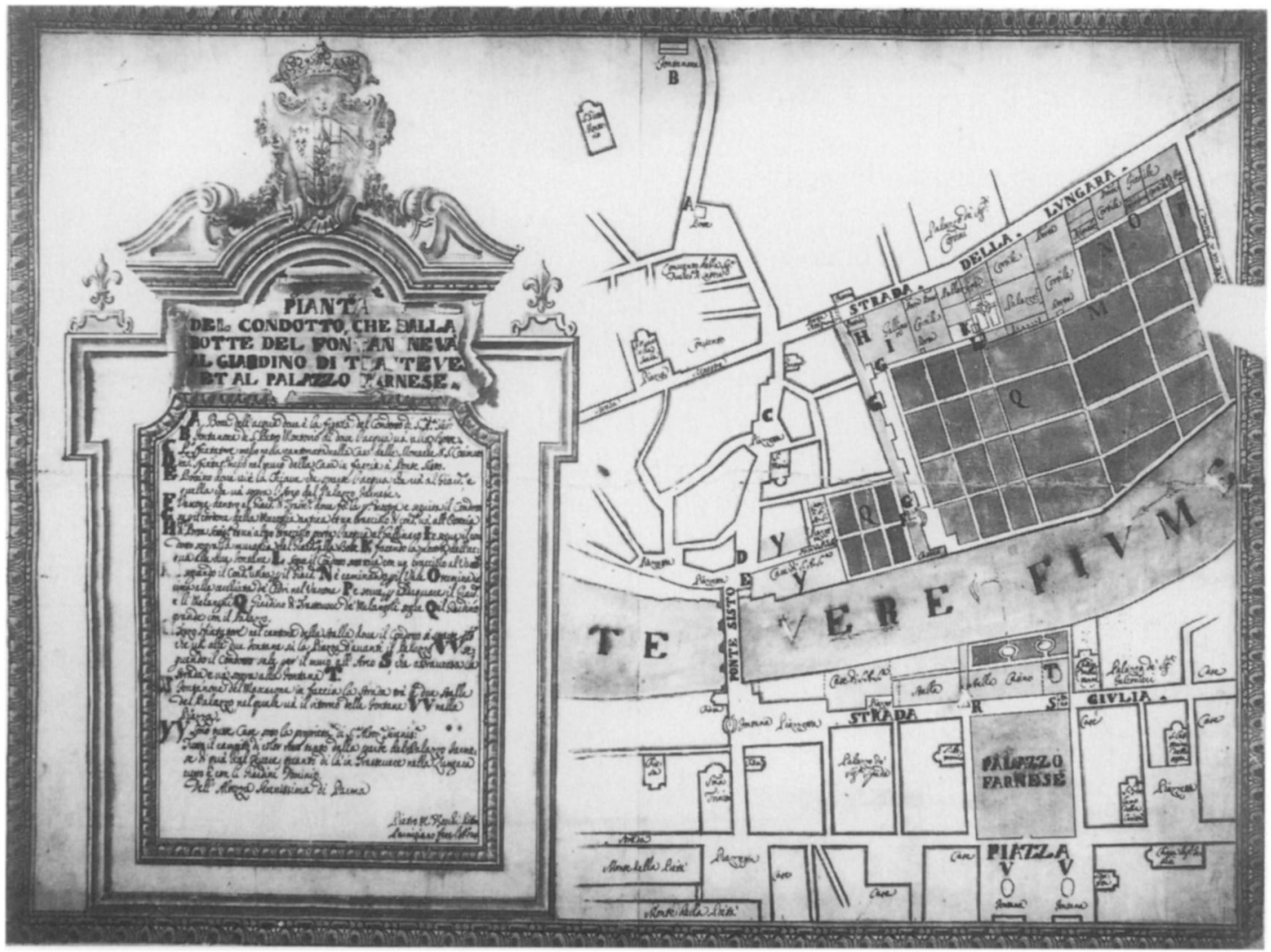

Fig. 27. Pietro Maria Boschi, plan of the two water conduits in the piazza Farnese. Naples, Archivio di Stato, Piante e disegni, cart. XXI, n. 1 (photo Archive).

make water part of the decoration of the second set piece, Bassetti tapped into this source. First he instructed the mason Bernascone to dig a ditch in the square. The plumber procured two large lead pipes from the Colonna dispensing storeroom "that had been used many times for the said function," and whose weight quartermaster Ludovisi assessed at 221 pounds; such a precaution, besides following to the letter one of the household directives, ensured that the pipe would not be cut down. Bassetti noted that a porter had had the pipes removed from the cellar and then transported to the square. They were set upright and joined by means of a lead soldering 7 once $(.13 \mathrm{~m})$ in diameter. The task of uniting the reused pipe to the main water supply could not have been accomplished had Bassetti not "advised the plumber who service[d] Palazzo Farnese to go turn off the water main at S. Pietro in Montorio." Bassetti characterized his own efforts as a "great inconvenience." He had to descend into the ditch, support the heads of the two pipes, and attach a strong soldering with large amounts of tin. At the free end of the recycled pipe, Bassetti added a footing of his own lead "and soldered completely around it."

Rione VII-Regola, pt. 2 (Rome 1976) 56. A seventeenthcentury plan in the British Museum locates the conduit that carried water from the Acqua Paola across the Ponte Sisto and into the southern Campus Martius; see C. H.
Heilman, "Acqua Paola and the Urban Planning of Paul V Borghese," Burlington Magazine 112 (1970) 660 and 663 , fig. 9. For the few known details of Boschi's career, see O. Michel, 581 . 
In addition, he supplied three pipes and another piece of new pipe with a large metal spigot "used to regulate the water." The constable paid the rental cost of these items. These pipes were joined by sawing and various solderings. The plumber then took a new length of his own pipe, cut it into three pieces, soldered the new pipes here and there, nailed them, covered them with putty, and suspended them in a harness within the barrel upon which the figure of Bacchus rests. He emphasized that he arranged the smaller pipes so as not to "move, enter, or go out." At one end of each pipe he attached a small washer or sprocket wheel made from his own lead. He stated that two of the pipes were designed "to throw up water from both ends." The other, set within the barrel, must have been connected to the water supply in the piazza. He described having joined "the arm of the said harness with the pipe that carries the water beneath the platform," a task that he accomplished "while standing with inconvenience," which resulted from working hunched over in a restricted space.

$\mathrm{He}$ also constructed a system of drainage pipes that carried water from the fountain of Bacchus to the sewer. The plumber used six pipes of his own lead for this purpose, which were "cut and bent," and for which the constable paid the cost of rental alone. Bassetti sensibly altered raw materials from his stockpiles to make this fountain. He cut one of the tubes in half, attached a washer at one end, and put them "underneath the bottom of the two basins." He then soldered the tubes, applied two layers of putty and hemp rope at the points where they passed through the basins, "so that water would not go out below," and nailed them to the inside surfaces of the basins. The plumber rightly stressed that water not seep from beneath the basins; if that had occurred, the visual and expressive character of the fountain group would have been compromised. Bassetti arranged the tubes in such a way that half their length projected above the surface of the basin and half below, "so that water would remain in the bottom." It is not possible to locate these basins in Vasi's etching. However, if water was meant to be expelled from both ends of the barrel, basins were probably located there, beneath the mouths or spigots. The basins would have maintained the conceit of the decoration as a whole, since receptacles were often placed at the mouths of wine barrels to catch drops. Tub maker Giuseppe Battistelli supplied two small oval tubs "with covers and feet" and a round tub. ${ }^{186}$ In any case, it appears that Bassetti was fashioning overflow pipes.

Next the plumber described having united the remaining pipes-two on one side, three on the other- "that lead the water down into the basins beneath the platform." These tubes were screwed into the two half-tubes mentioned above and soldered with tin. In addition, Bassetti made three small, square, perforated grates to place at the drains in the basins above, "which serve[d] to keep away the dirt, so that it would not clog the said pipes." He took another tube from his stocks, widened its mouth, and with hemp rope, putty, and nails, attached it to the hole in the basin beneath the platform. At the other end of the tube, from which waste water would be carried into the sewer pipe, he applied hemp rope and putty. In the space underneath the platform, he suspended both supply and drainage tubes by means of "twelve large iron hooks on the beams," a phrase that recalls the wooden armature so completely hidden by the painted and sculpted decoration. He tied the tubes tightly "so they would not move." To husband as much water as possible, Bassetti adjusted its flow. ${ }^{187} \mathrm{He}$ fashioned two large female screws and attached them to the mouths of the two spouts, which

${ }^{186}$ AC, I.A.436/110: "Conto di lavori fatti e Robba Data ... Da me Mastro Gioseppe Battistelli Tinozzaro ... E piu 2 tinozzelle ovate con Cappa e piedi per Servizio Della machina [scudi] 3.00/2:40; E piu una tinozella tonda per Servizio della machina [scudo] .60/.50."

${ }^{187}$ See the illustrations in [École Française de Rome], 2:60-61, 63 . 
were in the form of fleurs-de-lis. He wrote that the screws would "make the water flow less and strain to rise" and thus force it into the temporary conduit. Bassetti ends his catalogue by requesting payment for the services of an unnamed porter, whom he had paid "for the transport of all the above-mentioned pipes." In this instance alone, Bassetti's asking price was not cut, implying that the value of a porter's services was conventionally fixed.

Finally, the unnamed plumber of the Farnese palace was paid for having gone "to shut off and turn on the water at the water main at S. Pietro in Montorio." Bassetti wrote that much time was "lost" there, yet it was needed to carry out the trials "so that things would go well." The aqueducts of papal Rome furnished private buildings and public and private fountains. Water, too, played a fundamental role in the botanical and agricultural activities connected with the princely villas that surrounded the Eternal City and in the formal and symbolic outfitting of those architectural ensembles. The complex operations involved in harnessing that natural resource for a two-day festival are another mark of the status of the Chinea. Bassetti had mastered his tasks after years of service, upon which the Colonna came to depend.

\section{Other Component Parts and Finishing TOUChes}

The Colonna were lords of a number of small communities in Latium, for example, the fortress of Rocca di Papa on the northern slope of Monte Cavo, directly east across Lake Albano from the papal villa, Castel Gandolfo. On 27 June 1759, Clement XIII had just returned from his villa, "Wednesday evening after the Ave Maria," so that he could accept the Chinea the next day. ${ }^{188}$ In May 1759, the factor (fattore) of Rocca di Papa, Carlo Toietti, recorded two payments, one of 22.50 scudi to Cesare Pulidoro, who had made 15,000 bails "for the two set pieces of the fireworks," the other of 10 scudi to the carter Marc'Antonio Giulianetti, who had transported the bails to the piazza Farnese. One Giovanni Nicola Carnevale signed the receipt "by commission," an indication of Giulianetti's inability to write; Pulidoro, in contrast, signed with "his own hand." Procuring and transporting the bails amounted to 11.65 percent of the month's expenses at Rocca di Papa, so this activity represented a considerable outlay of labor and material resources. ${ }^{189}$

Pulidoro and Giulianetti received payment on 31 May, suggesting that bails had already been made and delivered to Rome before that date. If activities at the work site were efficiently organized, the bails were put to use quickly, about three weeks after the artisans' contracts were signed in the Colonna palace, and as demonstrated by the painters' extraordinary bill. Giulianetti transported his cargo in four wagon-loads (barozzate). The barozza could have a closed container or an open frame; both were pulled by pairs of buffalo or oxen. ${ }^{190}$ Giulianetti entered Rome at the Porta S. Giovanni; from there it is unclear whether he drove the carts directly to the piazza Farnese or whether their loads were broken up into smaller units, giving work to Rome's ubiquitous porters.

${ }^{188}$ Chracas, no. 6549, 30 June 1759,13 : "Mercordì sera
dopo l'Ave Maria il nostro SSmo Pontefice, e Principe
ritornò dalla villeggiatura di Castel Gandolfo."

${ }^{189}$ AC, I.A.440/157: "Esito a denaro fatto da me Carlo Tojetti Fattore in Rocca di Papa ... per il Mese di Maggio 1759 . . . [scudi] 22:50 mta pagati a Cesare Pulidoro per il prezzo di 15000 Cerchietti fatti per Le due machine . . . che si fanno a Piazza Farnese . . . alla ragione di [scudo] uno e [baiocchi] .50 il Migliaro come dalla riceuta 7; 10: [scudi] 10=mta pagati a Marc'Anto.o Giulianetti per la Vitt.ra di 4 Barozzate de Cerchietti Sudd.i portati in d.a Piazza Farnese per Servizio c Sopra alla rag.ne di [scudi] due e [baiocchi] $.50 \mathrm{La}$ Barozzata c.e dalla riceuta $8 . "$

${ }^{190}$ See Zabaglia, pl. xvI, N, P, and explanatory text; and Scavizzi, 49. 
These numerous bails bespeak the scale of the structures and the complexity of their decoration and further clarify the insistence in Grossi's contract that he procure an adequate number of assistants and foremen. The construction of a grassy knoll and artificial rock formations convincing in mass and volume required flexible supports that could be easily bent and twisted into different configurations, but not easily or efficiently unbent, since new bails were procured every year. Apart from Grossi's team, an indeterminate number of "bail men" (cerchiaroli) were engaged at the building site, splitting among themselves a full barrel of wine. ${ }^{191}$

Banners formed a prominent part of the decoration of the set pieces of 1759. Flag maker Ippolito Ricci collected four years' worth of Chinea-related expenses before he submitted his bill, an example of how long Roman merchants were willing (or forced) to forgo payment. In 1759 he provided twenty-two completely hemmed banners "of different colors" (namely, yellow and green), each of which was 6.5 palms in length and 6 in width $(1.45 \times 1.34 \mathrm{~m})$. He charged the Colonna for the price of thread and twine necessary to complete his work and the cost of dyeing the fabric; the latter expense, uncharacteristically, was not reduced by master of the household Orlandi, who audited the bill. ${ }^{192}$ The presence of the flag maker is confirmed by the bill of the ropemaker Tendel, who on 19 June 1759 gave the former 30.50 pounds of "fine, left-handed rope." 193 This may have been used for the manipulation of the banners shown draped over the parapets of the round fortress (fig. 1). As banners were hung from the façade of the Farnese palace, rope may have been used for that end, too. On 27 June, brazier Antonio Turchi provided fifty brass nails "for the finials of the flagpoles of the fireworks display in piazza Farnese." ${ }^{194}$

Turner Lorenzo Faggi presented a bill rich in descriptive detail. ${ }^{195}$ Specifying that architect Paolo Posi ordered all items, he began his account of activities performed with the turning of twelve wooden balls, two-thirds of a palm $(.15 \mathrm{~m})$ in diameter, which served as decoration "over the little houses of the sentry boxes." Eight are shown in Vasi's etching (fig. 1). The set piece being symmetrical in arrangement and having presented "uniform" elevations to both palace façade and square, the others stood at the four corners of the parapet that are, as it were, cut off in the etching. Faggi "made from scratch" ten pulleys, $5 / 12$ palm $(.09 \mathrm{~m})$ long, used "to hoist the small standards." A larger pulley made of walnut, 1 palm $(.2234 \mathrm{~m})$ long, was for raising "the middle standard." It is impossible to locate these objects in Vasi's etching, for neither he nor the draftsman from Posi's office who gave him a drawing would have taken the trouble to include them. Still, these details underscore the attention devoted to all decorative elements. Rather than painted papier-mâché

191 “Alli Cerchiaroli de Fuochi," 32 jugs.

${ }^{192}$ AC, I.A.409/183: "A di 20 Maggio ... Per Fattura di Aver fatto n.o 22 Bandiere di diversi Colori è queste Longe p.i 6:1/2 Large p.i 6: con il Suo Orlo dà Capo, e dà piedi à [baiocchi] .40: L'una [scudi] 8:80/5.50; Per filo è Spago per Cogire d.o Lavoro. Speso [scudi] 1:20/:80; Per Aver fatto Tingiere Cos. 8: Bar.na intrà gialla, è Verde per d.e Bandiere. Speso [baiocchi] :80/ :80."

${ }^{193}$ AC, I.A.436/66: "Li 19 d.o [Giugno] al banderaro con bollettino corda mancina fina [libbre] $301 / 2$ à [baiocchi] 17 1/2 la libb.a [scudi] 5=33 1/2." Andreini confirmed in his own hand that a receipt had been provided, but still cut the asking price to 4.50 scudi.

${ }^{194}$ AC, I.A.436/53: “@ di 27 Giugno dato 50 chiodetti d'ottone per li fiocchi dell'aste del foco a Piazza farnese [scudo] .15/.125."

${ }^{195}$ AC, I.A.436/29: "Conto di lavori fatti ad uso di tornitore per Servizio delle due machine di foco, erette in piazza Farnese in occasione della presentazione della Chinea ... ordinati dal S.re Paolo Posi Architetto ... a tutte robbe spese e fatt.ra di Mro Lorenzo Faggi Tornitore come Segue e vien descritto"; asking price, 3.55 scudi, payment, 2.18. 
spheres, Posi chose to adopt real wooden balls. Individual pulleys, which required time and no mean effort to fabricate, were fashioned for standards that may not have lasted more than two days. That standards could be raised and lowered demonstrates the marked degree of verisimilitude that festival designers like Posi desired in their works. Manipulating the standards may have formed part of a dramatization that was part of the fireworks display. Faggi supplied the balls and pulleys on 2 June, less than one month after the contract signing. By then the armature was completed to such a point, and the campaign of repainting after the rain so well under way, that decorative details of the first evening's structure could be put into place.

On 19 June, Faggi provided two additional items. He used the phrase "large onions" ("cipolle grosse") to describe sixteen wooden bosses, each $5 / 12$ palm $(.09 \mathrm{~m})$ in diameter and outfitted "with neck and hinge," further specifying that they were to be placed "above, at the platforms of the little palaces for the said set pieces." The word onion can refer to any bulbous form, and specifically to excrescences or knots in wood. ${ }^{196}$ Finally, Faggi requested payment for two large balls, $1^{1 / 12}$ palms $(.24 \mathrm{~m})$ in diameter, "to erect the standards." Perhaps they served as bases for the flagpoles on the right and left of both set pieces (figs. 1, 2). By refreshing his readers' memories, Faggi wanted to create an image of complicated, skilled work. ${ }^{197}$ Nevertheless, he did not receive what he requested.

Accounting records do attest to a flag maker's use of cloth. Still, viewers of Vasi's etching cannot simply assume that all flags depicted were the sole result of that artisan's handiwork. "Carlo Giuseppe Bassetti, Tinsmith at S. Eustachio," whom we have already encountered in the context of the fountains, fashioned twelve small pennons, each from a single piece of appropriately cut and shaped tin plate, "to put on top of the little houses of the sentinels." 198 By means of two hinged clasps, he attached these pennons to iron hinges set on top of the bosses made by Faggi, "so that [they] would turn according to the direction of the wind." Bassetti produced two larger banners of sheet iron that were meant "to be placed above, at the standards"; these must correspond to those set over the small towers and pavilions, as represented in both etchings (figs. 1, 2).

The bound captives that frame the clock constitute a well-known visual trope for conquest and were particularly appropriate in a structure sponsored by the Colonna family, as they would always recall Marcantonio Colonna's naval victory at Lepanto in 1571 (fig. 1). Bassetti was called upon to provide the chains that bind these figures and the shackles at

${ }^{196}$ See Grande dizionario della lingua italiana, s.v.
"cipolla."

${ }^{197}$ For a discussion of the intersections among the turner's art, architecture, and architectural theory in the seventeenth century, see J. Connors, "Ars tornandi: Baroque Architecture and the Lathe," Journal of the Warburg and Courtauld Institutes 53 (1990) 217-36. The plate volumes of the Encyclopédie devote 87 plates to turning. Plate XLVII, entitled "Tourneur, Ouvrages simples," depicts rounded forms named after comestibles (Olive, Pomme, and $(E u f)$; see Diderot and d'Alembert, 31:s.v. "Tourneur et Tour à Figure."

${ }^{198}$ AC, I.A.442/186: “Conto De Lavori Fatti E. Robba data per Servizio della presentazione della Chinea . . F Fatti per Ordine del Sig.re Pietro Battisti Sopraintendente, e del Sig.re Pauolo Posi Architetto Come Segueno aduso di Stagnaro. . . E. Più per robba Servita perla machina peraverli fatte e date nu.o 14 banderole di latta grossa intagliata contornate lequale Serveno per porre Sopra alli casotti delle Sentinelle cioue nu.o 12 grande di un foglio sano luna e per averle fermate adosso alli perni di ferro con due cierniere Saldate acio girasero atenore del vento perroba efa.a a [baiocchi] 25 luna [scudi] 3:/1:80; E. le altre due Servivono per porle Sopra alli due Stendardi fatte più grande di bandone con simile intaglio e fa.ra a [baiocchi] 40 luna :80/.50; E. peravere fatte due catene di latta di anelli elonge p.mi 8 luna e per averci fatte due colane grande per ponerle al collo delli due Schiavi sotto alli Stendardi perrobbaefa.a [scudi] 1:50/.84"; asking price, 5.30 scudi, payment, 3.14 . 
their necks. Thus, in the context of festive transformation, sculpted captives had real chains, but "cloth" pennons turned squeakily in the wind. The adoption of metal for the pennons may have had a practical purpose. Numerous fireworks were propelled forcibly through the air; although their expulsion could be orchestrated, their fall was uncontrollable. They could ignite cloth and thus cause serious conflagrations, as indeed occurred in 1731. ${ }^{199}$ Bassetti's banners may have been some small proof against unwanted fire. Remaining intact, they could also be used again.

There is a larger lesson to be drawn from Bassetti's handiwork and its relationship to Vasi's etchings. "Without metaphors," as J. Huizinga has written, "it is impossible to express a single thought. All effort to rise above images is doomed to fail." ${ }^{200}$ "Reading" prints or similar visual records of festivals for their political, historical, and symbolic content is a rewarding exercise, but the graphic record bears little immediately or unambiguously discernible relationship to what was constructed. There is no easy distinction between "true" and "false"; at issue are a series of approximate understandings of historical objects that are always difficult to retrieve and were, moreover, designed not to last.

In the case of the turner Faggi, one can see much of what he made in Vasi's etchings, which do not, however, tell the whole story. Before the explosion of the fireworks, both set pieces had to be lit to be visible at night. Such was the function of candelabra rented by quartermaster Ludovisi. ${ }^{201}$ Similarly, the glazier Giovanni Rinaldi provided three chandeliers "that were put in the set pieces in piazza Farnese." ${ }^{02}$ Festival-hangers, as has already been pointed out, attached papier-mâché leaves to "trees" that support the canopy above the bacchanal (fig. 2). However, real leaves and other plant materials were supplied by house gardener Francesco Masini, who was paid a monthly salary of 5.40 scudi, received a vinous payment, and split portions of bread with five helpers. ${ }^{203}$ Four men "who helped with the greenery" also obtained in-kind payments. ${ }^{204}$ Masini's activities were carried out "with the order of

${ }^{199}$ ÖS, RK 114 (letter from Rome of Cienfuegos dated 30 June 1731): "Si fecero poi i soliti Fuochi la sera con una ben'intesa machina, fatt'alzare dal Contestabile, e si sarebbero replicati ieri sera con altra Machina, come si è praticato gli altri anni, se nella prima sera in fine della Festa non si fosse per accidente, o per disattenzione degli Uomini attaccato fuoco alla Ossatura della Machina, talmente che non fù possibile estinguerlo, ed in poche ore si ridusse in cenere tutto il gran Castello di Legname, che la reggeva; onde per la brevità del tempo non si è potuta rimettere in piedi .... I danno di questo incendio è ben considerabile, ma poteva esser maggiore, se vi fosse in pericolo tutta l'Isola detta de'SS. Apostoli, che abbraccia il gran Palazzo de'Colonnesi, ed il Convento de'Padri Conventuali di S. Francesco." The accident occurred, according to Pier Leone Ghezzi, "e per trascuragine del focarolo e di Michetti misuratore, e non architetto"; see Pinto 1980 (as n. 127) 309. 275.055 scudi were spent "per una lista di Spese, e pagam.ti fatti in Occasione di d.a funzione, e per l'incendio seguito del pmo fuoco Artificiale"; AC, I.B.42, fol. 357 left. In that same year, the firework master Andrea Bonari received "[scudi] 130 per recog.ne accordatale dl 2.do fuoco che non potè ardere atteso l'incendio del med.o seguito la pma Sera"; AC, I.B.42, fol. 357 left. One Filippo Zarlati re- ceived 4 scudi "per l'incomodo dal med.o sofferto la sera delli 28 Giug.o pross.to per l'incendio seguito della pma Machina del fuoco Artificiale"; AC, I.B.44, fol. 600 left.

${ }^{200}$ Huizinga (as n. 16) 223.

${ }^{201}$ AC, I.A.437/139: "Nolo delli Candelieri per le Machine [scudi] 1:20."

${ }^{202}$ AC, I.A.437/131: "Per n.o 3 Lampadari che sono stati messi Nella Machina, nella Piazza Fernese [scudo] :90.”

${ }^{203}$ AC, I.A.443/145: "Francesco Masini Giardiniere [scudi] 5:40." "Al Giardiniere," 9 jugs; "Al Giardiniere con 5 omini," 18 loaves.

204 "A n.o 4 Omini che assistono alla verdura," 4 jugs; "A Quattro Omini, che assistono alla Verdura delli Fuochi," 4 loaves. To cite an earlier instance, greenery was procured from Colonna fiefs: " $\mathrm{E}$ a di=detto [31 Dec. 1741] [scudo] $1=\mathrm{mta}$ in cro al sudetto [Francesco Andreini] pagati li 28: d.o [June] à Fran:co Fazij per aver fatto in detta Macchia [Rocca di Papa] diverse frasche di Verdure in occasione di d:a funzione"; AC, I.B.46, fol. 687 right. 
the architect Paolo Posi." ${ }^{205}$ He placed "on top of the second set piece" vases of boxwood and flowers and bought greenery to strew upon the pavement of the square. This constitutes a striking attempt to incorporate elements of the natural world not only as decoration but as a tangible link between the rustic theme of the set piece and its resolutely urban enframement. Using four bundles of boxwood, Masini created the above-mentioned plantings, and then placed them in sixty-four vases, which he adorned with aromatic feverfew (matricale) and other flowers. ${ }^{206}$ Whether flowers, garlands, or the like were used within the palace is not indicated here, but the inclusion of plants, flowers, and waterworks within ephemeral structures was common practice in Roman festivals. A French traveler, writing of decoration he saw in 1760 in Rome at the feast of Corpus Domini, even linked the practice to the decoration of temples in antiquity. ${ }^{207}$ Elsewhere in Europe, structures set in gardens were fashioned completeiy from plant materials, further blurring the distinctions between nature and art. ${ }^{208}$

Additional documentary information on the adoption of greenery exists. Sixty "extralarge" vases in the shape of cooking pots, each with a capacity of a quarter-barrel, were procured from kiln-owner Ignazio Lombardi. ${ }^{209}$ Quartermaster Ludovisi records payment to an unnamed carter who "carried the vases back" to a repository, so they must have been rented, not purchased. ${ }^{210}$ Since storage space for the Chinea was at a premium, renting bulky planters would have avoided much inconvenience, especially since there was no guarantee that they would soon or regularly form part of any future year's decorative program.

The transformation of the first structure came about thanks to many individual efforts. Meals and wine went to "men who helped put back the set pieces." ${ }^{211}$ In earlier years, even

${ }^{205}$ AC, I.A.443/152: "Lista delle Spese fatte, et Opere poste dà Fran=co Masini per servitio delli Fuochi di Piazza Farnese con ordine del Sig.re Paolo Posi Architetto a $\mathrm{tt}=$ o li 29 Giug=o $1759=/$ Per omini cinque nel di 29 $\mathrm{d}=\mathrm{o}$ per accomodare li Vasi sopra al Foco con Piante di Busso e Fiori [scudo] 1=; Per Verdura comprata per buttarla per la Piazza [scudo] $=60$; Per quattro Fasci di Rame di Busso per fare le $\mathrm{dd}=\mathrm{e}$ Piante, e metterle in $\mathrm{n}=0$ 64 Vasi a [baiocchi] 20 il Fascio [scudo]=80; Per Matricale doppia et altri Fiori serviti per guarnire sopra $d d=i$ Vasi [scudo] $=60 /$ In tt.o [scudi] $3.00 /$ Hò ric=to dal S.re Fran=co Andreini . . . li sudd=i Scudi trè quelli sono per saldo della pnte Lista ... [signed] Frar=co Masini."

${ }^{206}$ For feverfew (Chrysanthemum parthenium), see L. H. Bailey and E. Z. Bailey, Hortus Third: A Concise Dictionary of Plants Cultivated in the United States and Canada (New York 1976) 268. Feverfew "floure[s] for most part all summer long"; J. Gerard, The Herball or Generall Historie of Plants, facsimile ed. (New York 1975) 652.

207 “Mais ce qui m'a fait le plus de plaisir et qui est particulier au jour de la Fête Dieu, c'est que toute la colonnade de St. Pierre est ornée de guirlandes de feüilles de chêne, usage pris chés les anciens et qui ressemble beaucoup à leur manière de décorer leurs temples dans les fêtes"; J. C. R. de Saint-Non, Panopticon italiano: Un diario di viaggio ritrovato, ed. P. Rosenberg (Rome 1986) 133.

${ }^{208}$ Chracas, no. 6553, 11 July 1759 (dateline Schleswig, 4 June) 4-5: “Li 2. è giunta Sua Maestà Danese [Frederick
V] in perfetta salute da Coppenaga in questa città, avendo al suo seguito, tra gli altri personaggi, i Ministri delle Corti di Vienna, Versaglies, Russia, Prussia, Svezia, Annover, Sassonia, Hassia-Cassel, Mecklemburgo, Olanda, ed i Deputati di Lubecca, Brema, \&c. . . Si era quindi schierato sotto l'armi all'ingresso del parco, ch'è presso il giardino di Gottorp, una parte degli abitanti di Schleswich; e l'altra, chiamata il corpo verde, avea preso posto vicino alla cascata, ch'è in esso giardino. Il Sig. Voss, Ispettore de'giardini, avea elevato sull'entrar del giardino suddetto dalla parte del parco, un arco trionfale di frondi, e verdura, colle cifre, e l'armi del Re; ed ivi appunto il Magistrato si diè l'onore d'umiliare al Re stesso i suoi omaggi." For a drawing (Florence, Uffizi 1014A) by Antonio da Sangallo the Younger of an "arco di verzura," see M. L. Madonna, "L'ingresso di Carlo V a Roma," in Fagiolo, 1:53, fig. 11, 55, and 65, n. 25.

${ }^{209}$ AC, I.A.436/67: “L'Eccma Casa Colonna Deve Dare li Seguenti Vasi 1759 ... A di 18 9bre N.o 60 Vasi Bastardelli à uso di Quartaroli Stragrandi per il Fuoco a [baiocchi] 12 [scudi] 7:20/6.00." The quartarolo was a dry or liquid measure equivalent to one-fourth of a barrel at Rome, or 14.585 liters; see Grande dizionario della lingua italiana, s.v. "quartarolo."

${ }^{210}$ AC, I.A.437/139: "Per un Caretto che a riportato li Vasi [scudo] .50."

${ }^{211}$ AC, I.A.437/139: "Per pranzo e cena della Notte per li omini che asistono per rimetere le Machine [scudi] 
members of the bookkeeper's staff were engaged in this activity, and a collective in-kind payment to fourteen unnamed individuals from that office suggests that the same occurred in 1759. ${ }^{212}$ Working quickly by artificial light soon after the first day's fireworks had been exploded, they removed the old applied decoration and replaced it with the new. These tasks called for concerted, efficient effort. To cite an example from eighteenth-century France, elaborate festivities were staged to celebrate the marriage of the dauphin Louis. An etching records some semblance of the transformation of the covered riding ring of the large stables at Versailles on 24 February 1745 (fig. 28). The inscription asserts that the ring, which the previous day had taken the form of a theater for a ballet, "was changed in the space of sixteen hours" to accommodate a masked ball. As though viewers would otherwise not believe it, the inscription insists that "the same room" served for both events. Thus, within a brief period of time, a space was twice rendered unrecognizable.

Six unnamed individuals obtained wine and bread "for having assisted at the Farnese palace at the fireworks displays." ${ }^{213}$ Andreini lists a payment of .20 scudo "for having had the canvases of the fireworks displays stretched," that is to say, the "white and red Brabant cloth canopy" described by the festival-hangers (fig. 2) that had been guarded for six nights before installation by the aptly named Antonio Malanotte. ${ }^{214}$ The bill of flag maker Ricci provides a sense of scale. On 20 May 1759, he recorded "having made a canopy of white cloth, and another of pink," 36 palms long, 30 wide, and 108 in circumference $(8.04 \times 6.70 \times 24.13 \mathrm{~m})$, and bordered with piping. Ricci described having added fringes, each $2^{1} / 2$ palms $(.56 \mathrm{~m})$ in length, to the large cloths, decorative elements that are visible in Vasi's etching. The flag maker also attached cords to the canvas for hoisting it into place. ${ }^{215}$ Extra hands were surely needed to manipulate this huge, heavy object.

Another German manuscript illumination shows the final form of the paradigmatic set piece whose very construction is analyzed in the text (fig. 29). The work of painters, sculptors, and other artisans who provided three-dimensional decoration is evident here. The finished structure is a fortress shown in a tilted perspective that allows for the maximum communication of information. Four corner towers with pyramidal roofs project dramatically from the body of the structure. At the apex of each pyramid, balanced precariously on cushionlike gilt rings, are fire- and smoke-breathing hybrid animals. In counterclockwise order from the lower left are a dog, a hind, a stag, and a winged dragon, all of whose bodies terminate in the twisted, scaly tails of fanciful sea creatures. High windows and keyhole gunports are the only breaks in the wall surfaces; no visible doors lead inside.

6:40." "All'omini che assistono, à mettere la 2:a machina," 16 jugs.

${ }^{212}$ In 1755, "Pranzo e Cena per Compotisti et altri che Asistono ripore li Fochi [scudi] 6.00"; AC, I.A.406/102; in 1757, "Per dui Pranzi per li Giovani di Compotisteria [insert in another hand: "et altri"] per Asistere alle Machine de fochi per Rimeterli [scudi] 7.00"; AC, I.A.422/ 178 ; in 1758, "Per Pranzi, e Cena per la Giente che anno asistito per ripore tutte le Robbe delli fochi e stata la notte [scudi] 12:10"; AC, I.A.428/152; in 1759, "Alla Comp.ria di S. Ecza per n.o 14 Persone,” 124 loaves.

213 “A n:o 6 Persone, ch'anno assistito al Palaz:o Farnese alle robbe de Fuochi," 96 jugs; "Sig:re Alberto Ludovisi
. . potrà dare a num:o sei Persone pag:te n:o Sedici, e Companatico Libre Otto a ciaschuno per avere assistito al Palazzo Farnese alle robbe de Fuochi della Chinea del pnte Anno li 30 Giugno," 96 loaves.

${ }^{214}$ AC, I.A.443/152: “Per haver'fatto stend.e le Tele de fuochi [scudo] .20"; see also n. 87 above.

${ }^{215}$ AC, I.A.409/183: "A di 20 Maggio [1759] . . . Per Fattura di Aver fatto un Padiglione di un Telo bianco, è un altro di Color di Rosa Longo p.i 36 Largo p.i 30 di giro p.i 108 con La Sua Cordicella tutto attorno, è fatto ogni telo il Suo pendone alto p.i 2:1/2, e messe le Sue corde cogite Sopra alle cogiture per Tirarlo per L'Aria, è d.o Serve per il Foco di Piazza Farnese [scudi] 12:00/7:00." 


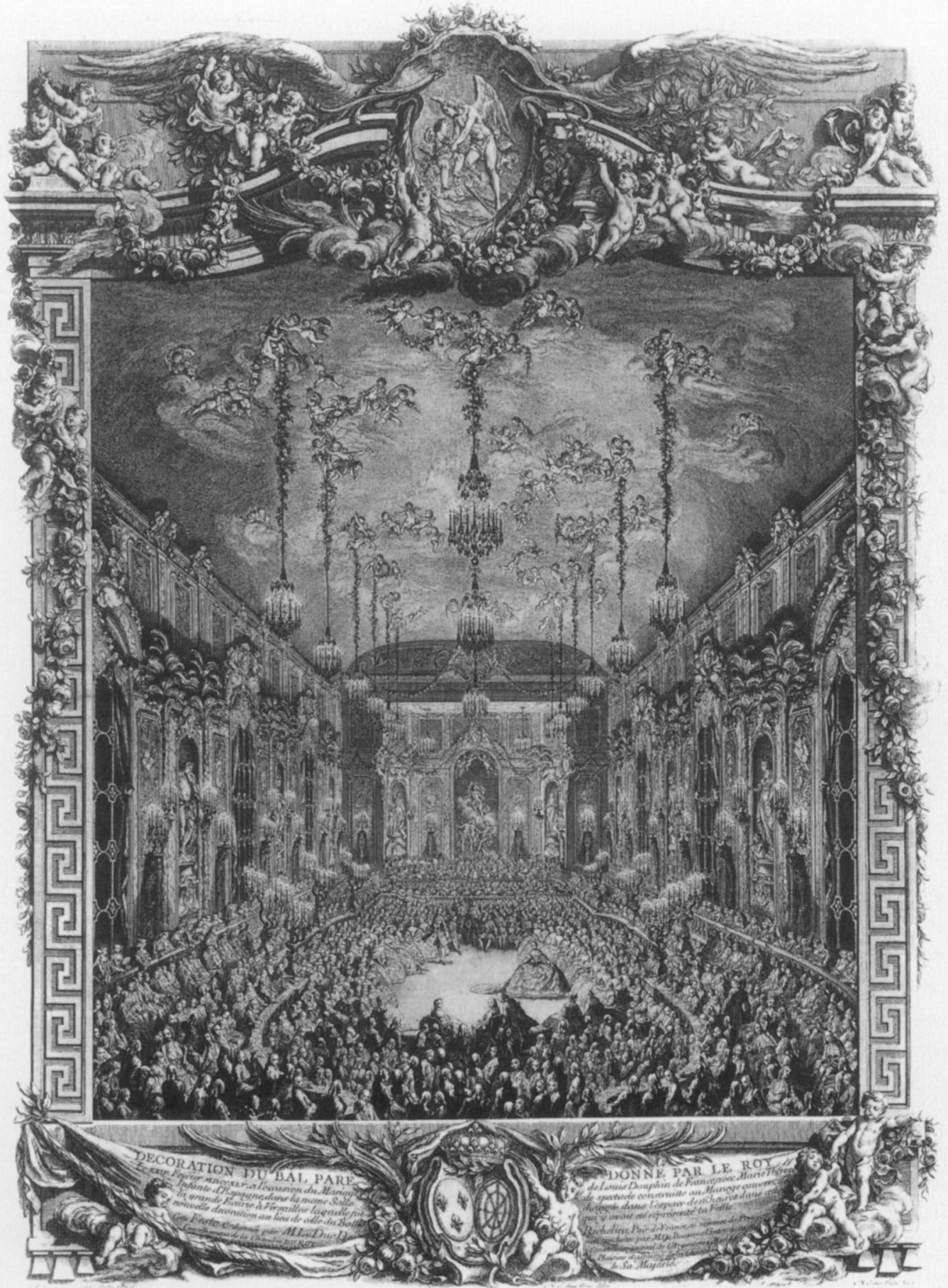

Fig. 28. Charles-Nicolas Cochin the Elder, dress ball given in the Riding Ring at Versailles, 1745, etching. Philadelphia, Philadelphia Museum of Art: W. P. Wilatscb Fund (photo Museum). 


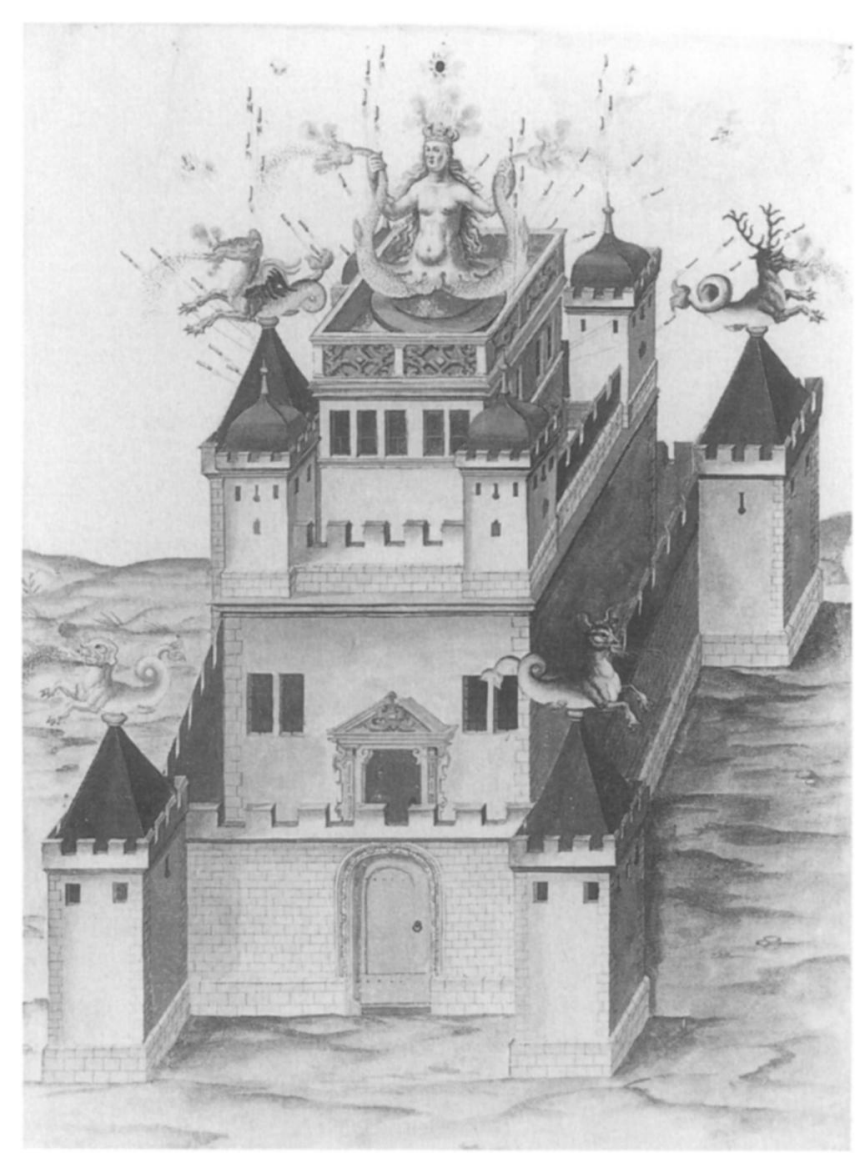

Fig. 29. Project for exterior decoration of a set piece. Karlsrube, Badische Landesbibliothek, Sign. HS. D 100 (photo Library).

A crenelated wall is shown as though made of rusticated blocks; through its roundheaded entrance portal one would ostensibly pass into the small space that isolates the tall block of the central structure on all four sides. A doorway with elaborate jambs and a pediment broken by a large escutcheon leads into the main building, whose smooth planar walls anchored by quoins pick up the surface treatment of the four corner towers. The sills of tall, paired windows are set on the same level as the entablature of the doorway; the long side of the fortress has no fenestration. On its upper story, the fortress is weighted at its four corners by bell-roofed towers capped by gilt finials. A belvedere-like sentry box rises from the mass of the lower supporting structure. Punctuated on all four sides by windows set in its upper wall surfaces and surmounted by a strapwork balustrade along its perimeter, the sentry box is crowned by a siren with long blonde tresses, a blazing crown, and fiery tail ends. Internal support for the siren is guaranteed by a long round pole, the uppermost extension of a larger, faceted post whose pencil-like extremity pivots on a crossbeam at ground level (fig. 15). The siren rests on a cushionlike stepped round base, which, along with the hidden vertical support, made possible a full revolution. ${ }^{216}$

Architectural details in this illumination confirm both the dating of the manuscript to the turn of the seventeenth century and its German provenance. Of equal importance is the pronounced sense of bright color, color that lent brilliance to Chinea-related structures, even

${ }^{216}$ For an illustration of a similar framework and external cladding, see Sievernich, 48-49, figs. 5/1.3-4. 
though the monochromatic prints of Vasi and all other etchers cannot show it. The symbolism of the didactic example in the manuscript also resembles that of the first set piece (fig. 1). Fortress imagery, reflecting both an idealized military prowess and the martial realities of European politics, appeared in many festival structures. The German illumination shows rockets that have been expelled with great force; Chinea set pieces encased similar pyrotechnic marvels. Billowing clouds of smoke are not only symbolically appropriate but also silent precursors of the evening's dazzling displays. With the visual image as the only evidence, how the German didactic structure would have taken on actual form remains a matter of speculation, yet patterns similar to those of the Chinea were likely followed. The monstrous animals who teeter on the pyramidal roofs must have been lightweight, fashioned with papier-mâché or painted canvas or paper stretched over an armature. The cushions on which these animals are balanced might have corresponded to the "large balls" that the Roman turner Faggi created to support the tall flagpoles of the two set pieces. A turner would probably have made the cushions and finials of the bell-roofed towers, which would then have been painted and gilt.

Artisans' contracts, an extraordinary bill that came after the rain, and accounting records have made possible a reconstruction of the work involved in building and decorating the set pieces. A regularly occurring act of diplomacy translated into a dependable source of income for many artisans and their workshops, who over time gained sound practical experience that reduced the risk of failure, the weather notwithstanding. The sculptor, painters, masons, carpenter, and festival-hangers, all of whom worked under strict time constraints, fulfilled the terms of their contracts, for no records exist of others who stepped in at the last minute. The patron-client relationship established by the Chinea was ultimately beneficial for all parties.

\section{ILLUMINATIONS}

Throughout Europe, illuminated palace façades signified celebration. "Cardinals, ambassadors, royal ministers, and other nobility" outfitted the exteriors of their palaces with temporary lighting fixtures to celebrate the feast of Sts. Peter and Paul, as did "many polite citizens" their simpler abodes. ${ }^{217}$ Venetian ambassador Pietro Correr, writing home to request reimbursement for moneys spent on lighting fixtures, asserts that he "follow[ed] the example of the other foreign ministers," implying that the expense was concomitant to maintaining his nation's status. ${ }^{218}$ On festival nights in eighteenth-century Rome, the flickering light of many torches, candles, and the famous "frying-pans" (padelle) rendered ephemera visible for the brief duration of their existence and set surrounding streets and squares in brilliant relief within a city that, lacking the public lighting found in London or Paris, was notoriously dark. ${ }^{219}$ In the numerous extant

${ }^{217}$ Chracas, no. 6549, 30 June 1759, 18: "In onore poi dei SS. Apostoli Pietro, e Paolo si fecero in quella sera, e nella seguente dalla fortezza di Castel S. Angelo le consuete vaghissime girandole; e le illuminazioni publiche di torce, fiaccole, lanternoni, ed altri fuochi di gioja, respettivamente a Palazzi de Sign. Cardinali, Ambasciatori, Ministri Regi, e di altra Nobiltà, siccome alle abbitazioni di molta civile Cittadinanza; e con la solita magnifica comparsa fu illuminata ancora la gran facciata, e la cuppola della Basilica Vaticana." A fiaccola was the pole on which the frying pan (padella) was supported; see n. 235 below.

${ }^{218}$ AS, SDR 280 (letter from Rome dated 30 June 1759):
"Seguendo l'esempio degli altri Ministri Forastieri feci per due sere l'illuminaz.e, per la quale imploro la consueta bonificazione." The year before, the Senate asked Correr "for more specific information regarding the Chinea," to learn why he had spent money on illuminations for the feast of Sts. Peter and Paul and for the presentation of the Chinea, which as a result of the vacant see had been presented on 8 Sept. 1758; AS, SDR 279 (letter from Rome of Pietro Correr dated 23 Sept. 1758).

${ }^{219} \mathrm{At}$ a time when many foreigners were arriving in Rome, the governor, "per il buon governo di questa Città . . . 
painted and printed representations of festivals, whether indoors or out, chandeliers and candles figure prominently. Yet visual images provide only a dim shadow of how spaces were transformed by artificial light, a major expense in eighteenth-century households. ${ }^{220}$ In 1759 a Lisbon newspaper recounted a story (subsequently dismissed as a fabrication) that told of a Jesuit in Naples whose room, inspected soon after his death, contained (among other things) huge amounts of money, gold, and 1,600 pounds of wax. ${ }^{221}$ Quite apart from its anomalous location or any overarching desire to discredit the Jesuits, that amount of wax signaled accumulated wealth in the form of an expensive commodity. In 1757, one Francesco Cavanna, a steward or carver (scalco) in the Colonna household, was discovered to have spirited away not only sugar, but 306 pounds of "candles for the table," acts of theft that cost him his employment. ${ }^{222}$

The Colonna administration was careful to record how many and what types of candles came in and out of the dispensing storeroom. "There must always be six links in the house," according to another of the household directives, "beyond that of the torch-bearer, and when they are bought, the weight must be known." 223 Hierarchical arrangements within the palace were encoded by light, its medium, and its olfactory qualities. The prince and his family received eight wax candles per evening from 1 October to 1 April, six from 1 April to 1 October. Rooms for female chaperones (duegne), guests, pages, and gentlemen-attendants were outfitted with fewer wax candles. Other rooms of the palace (secret kitchen, wine cellar, administrative offices, dispensing storeroom, stables), where nobles were less likely to go regularly, were illuminated with tallow candles. Among other properties, wax candles burn clean and have a pleasant scent, whereas tallow candles burn smokily with an offensive odor. ${ }^{224}$

Two merchants provided sources of illumination in the amount of $492.47 \mathrm{scudi}$, or 8.11 percent of total expenses for the Chinea of 1759 . The first, Benedetto Canali from Perugia, sent the Colonna wax specifically destined for the festival. ${ }^{225}$ In a handwritten bill dated 13

\begin{abstract}
hà suggerito alla Santà Sua di accendere di notte tempo i lumi, ed usare altre cautele, pratticate in Parigi, ed in altre Città d'Europa," an indication that the practice advocated was unusual; AS, MP 3460 (newsletter from Rome dated 9 Jan. 1734). "There are no lamps lighted in the streets at night; and all Rome would be in utter darkness, were it not for the candles, which the devotion of individuals sometimes place before certain statues of the Virgin. Those appear faintly glimmering at vast intervals, like stars in a cloudy night"; J. Moore, $A$ View of Society and Manners in Italy (London 1777) 1:388.
\end{abstract}

${ }^{220}$ When the type of wax used was specified, readers inferred the amount of money spent, as in this description of festivities held by Joinville, the French envoy in Genoa, to celebrate the marriage of the dauphin Louis: "alla sera poi nel Palazzo di sua abitazione vagamente adobbato, ed illuminato dentro, e fuori di cera bianca vi fù sontuosissima festa di ballo . . . una seconda seguì Mercordi . . . e la terza vi sarà domane . . . essendosi anche da questo Console, ed altri Nazionali illuminate con torce le loro abitazioni"; Chracas, no. 4306, 3 March 1745, 5-6.

${ }^{221}$ Pastor, 36:326, n. 2.

${ }^{222}$ AC, I.A.421/170: "Introito à Candele da Tavola . . . A di 16=Giugno Candele da Tavola trovate in essere nella stanza di Fran.o Cavanna L.e 306.”

${ }^{223}$ AC, II.A.18, no. 46: "Torcie a vento ne doveranno essere in Casa sempre 6. oltre quella della torciera, e quando si comprano si doverà sapere il peso."

${ }^{224}$ Liberati, 176-77: "La prouisione delle candele in Roma, e necessaria più che l'altre . . non tanto per lo sparagno, come per euitar la puzza, che rende la candela cattiua. Il vero tempo da prouedersene è l'Autunno, e non passare il mese d'Ottobre, prima che se ammazzino li porci, che allora sono tutte di seuo d'Agnello, e di Vaccina. Che si riduce a farla di Primauera non può seuirsi di loro nell'Estate, così per l'accennato fetore, come ancora perche non potrãno stare in piedi, essendo fatte di cattiua materia, nè resisterãno al caldo." For an anecdote relating to the unpleasant olfactory and gustatory difference between tallow and wax, see N. Adams, "Censored Anecdotes from Francesco Maria I della Rovere's Discorsi Militari," Renaissance Studies 13 (1999) 58.

${ }^{225}$ AC, I.A.436/54: "Conto di Sei Casse Cera bl tt:o Compim.to Sped.e col Vett.le Bartolomeo di Lorenzo il Moretto . . per La Funzione della Chinea." The wax 
June, he recorded the gross weight of the shipment, 1,651.50 pounds, from which he subtracted the real tare of 224.50 pounds for the crates, resulting in a net weight of 1,427 pounds. To the cost of the wax he added the price of the packing crates themselves and the rope nets (ammagliature) that surrounded them. He described the crates as "extremely well wrapped with rope and packed," evoking the care required for merchandise sent long distances and justifying the extra charge. The cost of transport was then subtracted from the overall cost of merchandise and packaging. On the face of the bill, quartermaster Ludovisi enumerated the types of light sources that were made from the wax-torches, candles for chandeliers, and candles for the table-all arranged in descending order of unit weight.

Canali's business was extensive enough to occasion the use of preprinted customs forms. He expected the wagoner, Bartolomeo di Lorenzo il Moretto, to consign the wax within the space of five days; the wagoner was in turn to be paid 4.50 scudi per load. Days beyond this period increased the cost of transport by .50 scudo per diem, Canali absorbing the extra cost. In 1759, delivery must have occurred within the stipulated period, for on 23 June a payment of 13.50 scudi is recorded "to Bartolomeo di Loreto for the transport of six cases of wax." 226 The Colonna absorbed certain ancillary costs related to this purchase. On 23 June, dispensing-storeroom clerk Antonio Montelli was reimbursed by Andreini for customs costs exacted the day before by the monopoly (appalto) on tobacco, which taxed goods coming into Rome from the provinces of the Papal States. ${ }^{227}$ Payments-in-kind to a porter connected to the customs house in the piazza di Pietra reflect the ultimate transport of the wax to the Colonna palace. ${ }^{228}$ Thus the wax arrived in Rome five days before 28 June.

The second merchant, Roman tallow chandler Pietro Livotti, also enjoyed the fruits of Colonna patronage. In a sale that represented just over 25 percent of the money he earned from the Colonna in 1759 , he provided ninety-eight dozen "ordinary candles" (produced by dipping), each of which weighed 10 Roman pounds, and a gross of more expensive moldmade candles. ${ }^{229}$ As it happens, in 1759, Livotti supplied the household with just over 25 percent of its total provision of these two types of tallow candles according to Ludovisi's accounts, in which it is recorded that moldmade candles were used "for the fireworks structures." ${ }^{230}$ For comparison, in the holy year of 1775 at

cost 31 scudi per cwt., yielding 442.37 scudi; cost of six crates and "Ammag.re," 3 scudi; sum reduced by cost of conveyance, 13.50; total cost, 431.87 scudi. There were 253 torcie ( 877 lbs.), 1,018 candele da tavola (249 lbs.), and 389 candele da lampadari (264 lbs.).

${ }^{226}$ AC, I.A.443/152: "A Bartolomeo di Loreto per porto di n.o 6 Casse di Cera [scudi] 13:50," with preprinted customs form attached.

${ }^{227}$ AC, I.A.443/152: "Io Sottoscro hò ric.to dal Sig.re Franco Andreini ... Scudi Cinque, e [baiocchi] :82 1/2 mta quali sono per altretanti pagati in Dogana di Terra per la nuova Imposizione per l'Appalto del Tabacco sopra Casse Sei Cera venuta di fuori per servo dell'Eccma Casa. In Fede qsto di 22 Giugno 1759 / [signed] Antonio Montelli." For monopolies, see Gross, 119-28. Montelli, who numbered among those staff members called ministri in the monthly salary rosters, was listed as a "giovane di computisteria" in June 1759, receiving 2.50 scudi; AC, I.A.479/151. Vinous payment is also recorded "Al S.re Antonio Montelli," 16 pots.
228 "Al Facchino della Dogana di Terra," 2 pots and 4 loaves.

${ }^{229}$ AC, I.A.436/87: "Conto di Candele di Sevo date per Servo in Occasione da rapresentarsi L'Achinea / Candele ordinarie Consegnate da dispensarsi in tt.o Xne 98 [scudi] 52.92 / Candele da Stampa Consegnate per Lampadari in tt.o Xne 12 [scudi] 7.68/ Che alle Ragg.e di [baiocchi] $54 \mathrm{La}$ Xna Candele Ordinarie [baiocchi] 64 La Xna Candele à Stampa cosi concordatamente stabilite in tt.o importano Scudi Sessanta è [baiocchi] $60 \mathrm{mta}$ [scudi] 60.60." Cash total in 1759, 240.57 scudi. In 1755 Livotti's shop was "alla Rotonda"; AC, I.A.403/54. Roman tallow chandlers were legally bound to obtain raw materials from the city's butchers; Gross, 92. For candlemaking and the differences between "chandelles à la baguette" ("chandelles plongées") and "chandelles au moule" ("chandelles moulées"), see Diderot and d'Alembert, 3:s.v. "chandelle" and 22:s.v. "chandelier," pls. I, II.

${ }^{230}$ AC, I.A.437/141: "Introito à Candele di Sevo . . . $28=$ d.o [Giugno] da d.o [Pietro Livotti] per la funzione 
the church and hospice complex of SS. Trinità de' Pellegrini, 55 pounds of tallow candles were deemed sufficient to mark the election of Pius VI. ${ }^{231}$

Francesco de' Marchi provided the Colonna with 1,900 paper lanterns "with the arms of the King of the Two Sicilies." ${ }^{232} \mathrm{He}$ wrote on the bill that 1,000 lanterns had been sent to the Farnese palace, 900 to the Colonna; thus two palaces and the squares in front of them were transformed by translucent symbols of an absent monarch. Permanent lanterns could be made of tinplate or glass, but here the large number confirms the use of paper, a substance less expensive than any metal and thus appropriate for an ephemeral event. Such lanterns were typically hung outside windows. ${ }^{233}$ Setting tallow candles within them produced an evenly diffused light that enabled one to see palace and church façades at night, as well as painted and sculpted figures and inscription plaques attached to set pieces. ${ }^{234}$ In describing services rendered, de' Marchi uses the phrase "as usual" ("come il solito"), a characterization with which neither Ludovisi nor Andreini had any quarrel, for the former received the goods and the latter approved the full asking price. An item in the bill of Giuseppe Pizzitutti, "basket-maker at S. Eustachio," describes "four round baskets with their handles for carrying lanterns and fiaccole." ${ }^{235} \mathrm{He}$, too, was a familiar purveyor, but his asking price was cut by 50 percent. ${ }^{236}$

della Chinea [libbre] $980 /=$ d.o Candele da Stampa per le Machine de Fuochi [libbre] 120."

${ }^{231}$ Entrata, xxvii: "Pagati al Festarolo per l'Illuminazione del nuovo Sommo Pontefice Papa Pio VI. compresoci l'importo di lib. 55 Candele di Sevo per la medesima, e per la Festa di S. Filippo [scudi] 15.335."

${ }^{232}$ AC, I.A.436/31: "Conto de Lanternoni fatti per la Chinea dell'Anno 1759 ... Per aver fatto Mille e Novecento lanternoni con l'arma del Re delle due Sicilie, mille mandati al Palazzo Farnese e novecento al Palazzo Colonna a pauoli Sei il Cento Come il Solito [scudi] 11:40." In 1757 De' Marchi's shop was "alli Crociferi"; AC, I.A.421/62. The material of lanternoni is provided in the title of an archival document, "Ragioni, per le quali si è stimato indispensabile il farsi l'illuminazione di semplici lanternoni di carta per due sere secondo il solito"; AGS, SE 4936.

${ }^{233}$ Bologna, Archivio di Stato, Ambasciata bolognese a Roma 154 (copy, under the heading "Magistrati," of a letter of Count Petronio Isolani dated 2 July 1760): "Secondo le memorie, le quali si trovano in questa Seg:ria, e secondo l'inveterato stile de'miei SS:ri Antecessori, nelle due sere della vigilia, e del giorno della solennità di S. Pietro hò fatta la illuminaz.e nel Palaz:o di mia Residenza con Lanternoni alle finestre. e havendo osservato, che i Ministri delle Potenze Straniere, quantunq.e non abbiano spiegato in questa Corte il carattere, e non godano il trattam:to di Amb:ria usano, in vece de'Lanternoni, le torcie di cera bianca, reputo di pub:ca convenienza il seguitare negli anni avvenire il loro esempio. Prima però di recare questa mia intenzione ad effetto la sottopongo alla savia consideraz:e delle SS.VV., e starò attendendone il lor sentimento."

${ }^{234}$ Von Rohr, 847: "Bisweilen ist ein Feuerwerck und eine
Illumination mit einander vermischt. Man stellet, z. E. einen prächtigen Tempel oder ander Gebäude vor, mit trefflichen Colonnaden, Pfeilern und Statuen, die bey der Nacht, durch die mit Papier umgebnen Lichter ganz erleuchtet sind, dergestalt, daß man historische Bilder und Schrifften, welche sich in einem solchen Gebäude hin und wieder befinden, sehr deutlich sehen kan. Je grösser die Gemählde, je deutlicher kan man sie des Nachts bey der Erleuchtung observieren."

235 “Le 24. 7 bre tout etant preparé pour la feste, elle fut annocée au peuple dans le moment que les 24 . heures sonnerent par le bruit de cent boites disposés dans la petite place de l'Appolinaire, dans le palais que j'occupe fait un des 4. angles. Au milieu étoit representé un fort à quatre bastions, sur le quel s'elevoit un grand bassin, qui jettoit cinq fontaines de vin. Il étoit entouré comme la place de poteaux peints, qui soutenoient de pots à feu. . . J'aurois même embrassé par mes poteaux a feu qu'on appelle icy fiaccole toute la place Navone, sans les egards que j'ay eû pour les Espagnols, dont ils m'ont bien remercie"; AN, AE B.I.667 (enclosure in a letter from Frascati of Polignac dated 11 Oct. 1725). Wooden poles are depicted in several prints related to the Chinea, as in figs. 22 and 23 of this article. For other examples $(1722,2 ; 1723,1 ; 1723,2$; 1728,$1 ; 1731,2 ; 1732,1 ; 1732,2 ; 1733,1 ; 1733,2$; and $1745,1)$, see Gori Sassoli, passim. The distinction between support and contents is made explicit in the following document: “@ d.o [28 June 1723] [scudi] 19:95 mta ... per intiero pro di n:o 100 Ciambelle di pece, di peso L:e 499, à Rag.e di [baiocchi].4 la lib.a Servite per le fiaccolette per d.a occorrenza [la Chinea]"; AC, I.B.39, fol. 527 left. In 1725, "ciambelle di fiaccole" are mentioned; AC, I.B.39, fol. 678 left.

${ }^{236}$ AC, I.A.436/30: "Conto di Lavori fatti da Gioseppe Pizzitutti Canestraro a S. Eustachio ... in occasione delli 
Torches were carried by servants to light the ascent and descent of guests attending receptions. ${ }^{237}$ "For the illumination of Palazzo Farnese," 710.50 pounds of Venetian wax flambeaux with four wicks were drawn from the reserves of the Colonna household, an amount that represented nearly 50 percent of the annual disbursement. The gross weight corresponded to 204 individual units, which were sent to the palace on 25 June. ${ }^{238}$ Each weighed approximately 3.48 Roman pounds $\left(1.18 \mathrm{~kg}\right.$ ); collectively, they cost 216.50 scudi. ${ }^{239}$ Although some torches were probably used outdoors, others were certainly used inside the Farnese palace. The evidence for this rests in the costly material, Venetian wax, from which the 250 pounds of "table candles" drawn from household reserves were also fabricated. Quartermaster Ludovisi's monthly accounts show that 30 percent of the latter disbursement consisted of candles "for the table" (i.e., set into candelabra), as opposed to 70 percent "for chandeliers." 240

Ludovisi maintained a separate account for "singed wax," as it was common and economical practice to retrieve pooled drippings and partially burned candles and flambeaux, whether of wax or tallow. ${ }^{241}$ The pattern is confirmed by a contrasting situation. In 1644, as part of the celebrations for Giambattista Pamphili's elevation to the papacy as Innocent X, when half-burned flambeaux used to illuminate palace façades around the piazza Navona "were thrown to the people," the action was considered worth mentioning in a contemporaneous printed description, from which it may be inferred that such largesse was unusual. ${ }^{242}$ A June credit entry in Ludovisi's accounts refers to "diverse pieces of candles for chandeliers ... given ... for service ... [in] the apartment of Palazzo Farnese." Of 67 pounds disbursed, 63 (in 102 pieces) were for the chandeliers. ${ }^{243} \mathrm{~A}$ June debit entry records that the remains of flambeaux and candles for

Fochi di Piazza Farnese . . . del presente anno 1759 . . . E più n:o Quattro Canestre tonde coi suoi maniche per portare Lanternoni, e Fiaccole [scudi] 1:20/-60."

${ }^{237}$ Autobiography of Miss Cornelia Knight, Lady Companion to the Princess Charlotte of Wales, vol. 1 (London 1861) 53: "When a lady went to a conversazione, her servants called out 'Torcie!' and two servants of the house would come down, each with a torch, to light her up the stairs. Sometimes at very great assemblies, or at a fête, the court and the whole staircase were as light as day with torches placed everywhere. At such times they were not called for."

${ }^{238}$ AC, I.A.437/141: "Conto di Torcie à 4 Stuppini di Cera di Venezia ... A Spesa per la Chinea per L.e 710:06 in n:o 204 Torcie di Cera Sud:a date nel mese di Giug.o pass:o per l'Illum:e del Palaz.o Farnese le due Sere delli 28, e 29 di . . . Giug:o . . ." On 25 June, the flambeaux were "mandate al Palazzo Farnese in occasione della funzione della Chinea."

${ }^{239}$ AC, I.B.49, fol. 917 left: " $E$ a di=detto [scudi] 213:15 mta in cro al sudetto, vta coma sopra di L:e 710:06 Cera in n:o 204=Torce à quattro stoppini date in d:o mese per l'illuminazione di detto Palazzo [scudi] 213.50."

${ }^{240}$ AC, I.A.437/14: “A Spesa per la Chinea per Candele Sud:e [di cera di Venezia] date, nel mese di Giugno passato, e Candele da Lampadari parim:ti date in d:o mese per l'Illuminazione del Palazzo Farnese." The June disbursement totaled $301 \mathrm{lbs}$., of which 75 consisted of "candele di tavola," 175 of "candele da lampadari."

${ }^{241}$ Liberati, 103: "Lo Scopatore segreto non hà cura d'altro che delle stanze del padrone, e de'candelieri di essa, però douerà farsi dare dal Dispensiere le candele per la sala, e camere, e venendo in mano a lui le candele di cera per accenderle, nel ricuperare li candlieri, si farà dare ancora li pezzi delle candele auanzate la notte, perche quelle oltre al cambiarli in altre candele, seruiranno ancora per impannate nelle occasioni, e per altri seruitij necessarij." On 29 Oct. 1755, singed wax was used for making a death mask of Fabrizio Colonna, who died the previous day: " $E$ a di=detto [31 Dec. 1755] [scudo] $=54 \mathrm{mta}$ in cro al Sudetto [Alberto Ludovisi], valuta per commod à [baiocchi] 27 la \#.a di \#.e 2=Cera Arsiccia data li 29: Ott:re pas:to per far la Maschere al Cadavere di d:a ch: me:"; AC, I.B.49, fol. 429 left.

${ }^{242}$ A. Gerardi, Roma festeggiante per la elettione del nuouo Pontefice Innocentio X. Romano (Rome 1644) [5]: "Era vaga cosa il vedere la strada di Parione, e la Piazza di Pasquino, e quella di Nauona, ambedue Piazze, che circondano il Palazzo de'Signori Panfilij habitatione di Sua Santità, mentr'era Cardinale, poiche tutti i Palazzi circonuicini ... posero alle finestre torce di cera bianca; e verso le due hore di notte per tutte le tre sere sudette si buttaua al Popolo l'auanzo delle medesime torce."

${ }^{243}$ AC, I.A.437/141: “A Spesa per la Chinea per L:e $67=$ Cera Sud:a in diversi pezzi di Candele da Lampadari, 
chandeliers amounted to 444 pounds in 1759 , representing 98.66 percent of all such wax returned to the Colonna dispensing storeroom in that month. ${ }^{244}$ As a result, the expense incurred for procuring wax for the Chinea provided the Colonna with stores for the entire year. "In lieu of the wax drippings," Domenico Galavotti, dean (decano) of the grooms, received a portion of wine and the substantial cash payment of 15 scudi. ${ }^{245}$ The job was immense: it involved climbing ladders, removing candles, and scraping wax from the sockets of chandeliers and candelabra.

The characteristic flickering lights that cast eerie shadows upon the ubiquitous shrines in Rome's tangled web of dark streets could hardly begin to compare with the effect of entering the piazza Farnese on the night of 28 June: there, strangely visible, rose a tall, brightly painted structure, outfitted with over-life-size figures; there an embassy appeared dramatically transformed, its windows emitting brilliance from within and without; there the smaller palaces and apartment blocks were rendered miraculously visible by warm circles of light.

\section{FIREWORKS}

Like architecture, painting, sculpture, music, etchings, and food, fireworks took their place among the arts of the ephemeral. The enjoyment of fireworks, whose "always copious, always varied, and vigorous" display could last some forty-five minutes, enlisted many of the senses. ${ }^{246}$ The acrid smell of burning powder was a standard marker of ambitious festivities. The deafening sounds of explosions must have seemed to shake the imposing mass of the Farnese palace, to say nothing of smaller-scaled, even dilapidated structures on the square, which threatened collapse as a result of "the excessive and continuos roar of the salvoes." 247 Different effects were experienced by distant observers, for whom muffled or thunderous blasts and brilliant bursts of light nonetheless betokened celebration. The dazzling display throughout Rome caught the attention of those who experienced the fireworks at close hand, whether standing in the densely packed square, or on a balcony overlooking it, or in the safety of a nearby villa or palace, whence some buildings in Campus Martius were repeatedly thrown into spectral relief. ${ }^{248}$ Snakelike objects wriggled upward, then dissolved into showers of sparks

date nel mese di Giug:o pass:o per Servizio de Lampadari dell'Appartam:to del Palazzo Farnese"; "25=d.o [Giugno] mandata al Palazzo Farnese . . . n.o 102 pezzi di Cera Arsiccia [libbre] 63"; the June disbursement totaled $71 \mathrm{lbs}$. The remaining $4 \mathrm{lbs}$. were distributed on "27=d.o [Giugno] alla Credenza al Palazzo Farnese . . . per attaccare li Cristalli alli Trionfi [libbre] 4"; AC, I.A.437/141.

${ }^{244}$ AC, I.A.437/141: "E a di 31 Dec.re Libre Seicentosettantasei, e O:e 07 Cera arsiccia, che assegna il Sud:o Ludovisi essergli ritornata in dispensa . . . la medema proveniente dalle ... Candele da Lampadari, altre Torcie esitate ... per l'Illuminaz:e del Palazzo Farnese." A marginal note here reads "Chinea L.e 444"; total June intake of singed wax was $450.08 \mathrm{lbs}$.

245 "A Dom:co Galavotti," 6 pots; "A Dom.co Galavotti In luogo della Scola.ra della Cera [scudi] 15:"; AC, I.A.443/152.

${ }^{246}$ AS, AER 1244 (letter from Rome of Giovanni Porta dated 30 June 1739): "il Fuoco della Piazza, che durò tre buoni quarti d'ora sempre copioso, e sempre vario, e gagliardo."

${ }^{247}$ Writing of the fireworks accompanying the celebration of the marriage of the dauphin Louis, Ascolese noted that "benche lo strepito delle batterie fosse veramente eccedente, e continuo," it caused no damage to the Neapolitan post office, which was in a ruinous state; AS, AER 1065 (letter from Rome dated 22 May 1745).

${ }^{248}$ Chracas, no. 5925, 5 July 1755, 19-20: "La Signora Margravia di Brandemburgo Baraith Culmbach ... volle godere di tutte le suddette solenne funzioni, colla sua nobile Comitiva di Dame, e Cavalieri, in diversi luoghi, onde è che il passaggio della cavalcata della Chinea l'osservò da uno de loggioni della facciata della Basilica Vaticana, che riguarda la piazza; e da uno de fenestroni, che dalla parte opposta alle loggie corrisponde nella Chiesa ne vidde l'atto della presentazione .... In quanto poi alli sunnominati fuochi di piazza Farnese fu a goderli amendue le sere dalle fenestre del Palazzo dell'Illma Casa 
and streamers. The very experience of time was altered. A pitch-black sky of infinite expanse, punctuated by innumerable distant stars, served as the backdrop for an airborne drama that seemed to bring glowing-hot heavenly bodies dangerously close to earth. Looking upward and listening, viewers followed the sizzling trajectory of a Roman candle, certain that after a spectacular decomposition, the projectile would have exhausted itself. Those seconds of silence and darkness, such important elements of the entire aesthetic composition, were truncated by further activity, which to the same astonished audience would otherwise have seemed a physical impossibility. ${ }^{249}$ Differentiation and transformation, intersection and dispersion, time and process, are among the salient features of this fiery realm of the visual; an eighteenth-century text even calls one type of firework a caprice, a term that recalls a pictorial genre and an aesthetic category of the period. ${ }^{250}$

Signing their names to a document that was to have the same value as one "sworn by the hand of any public notary," Francesco Scardovelli and Antonio Silici committed themselves to equip the entire fireworks display on 8 May 1759 (Appendix, doc. 6). Explicit reference to "what was carried out in past years" recalled their long-standing experience with the Chinea, which can be traced to as early as 1740 , and which for Scardovelli ended with his accidental fall from a set piece in $1769 .{ }^{251}$ They were paid 450 scudi in installments as their work progressed and also received large disbursements of wine and bread. ${ }^{252}$ The constable was to provide approximately 120 pounds of "fine powder," 20 of saltpeter. The firework masters differed from other artisans active in the Chinea in that they were required to "credit [the constable] with the said price" of these raw materials.

For powder and saltpeter, Lorenzo Colonna turned to his fiefs, just as he did when procuring metal bails. The town of Paliano, located in northern Ciociaria and overlooking the nearby via Prenestina from a hilltop $440 \mathrm{~m}$ above sea level, was the ancestral home of the Colonna whence, well before the so-called "Babylonian Captivity," they had struggled with the papacy in order to establish an independent dukedom. At Genazzano, roughly $7 \mathrm{~km}$ northwest of Paliano, treasurer Claudio Trifogli drew up an annual balance sheet that included the fortress at Paliano. In June 1759 the production of gunpowder and saltpeter cost 20.15 scudi. The bill that overseer Giovanni Angelo Carabella presented on 3 June indicates that the fabrication of these substances began in May. ${ }^{253}$ Carabella was reimbursed for having had refined

Mandosi, ivi esistente; Le girandole, fu invitata a vederle, la prima sera da questo Monsig. de Canilliach, nel suo Palazzino con Giardino vicino a S. Pietro in Montorio, dove fu trattata con un lauto rinfresco; e la seconda fu similmente invitata dall'Eccma Casa Corsini, nel Palazzo di Casa Altoviti loro parente, in vicinanza del Ponte S. Angelo, di dove molto commodamente, e da vicino se ne ammira la comparsa; fattogli a tale effetto preparare l'appartamento, ed ornare nobilmente la loggia, perche non abitato presentemente da detti Signori Altoviti."

249 "Der Unterscheid der Donner= und Blitzfeuer, der Lust $=$ Kugeln, der Freuden $=$ Feuer, Thau $=$ und Regen $=$ Feuer, ist wohl in Betrachtung zu ziehen, und so wohl das Knallen und die Stärcke, als die Schwäche, das stille Wesen und die Lieblichkeit nach der Erfindung zu beurtheilen"; von Rohr, 849-50.

250 "Fig. 6. ein über und unter sich werfendes Feuerrad,
Caprice genannt"; caption accompanying pl. vII of J. D. Blümel, Gründliche Anweisung zur Lust-Feuerwerkerey (Straßburg 1771), quoted in Sievernich, 37, fig. 3/14.2.

${ }^{251}$ Scardovelli is called "Capo Bombardiere, e Capo Focarolo di C.S.A." on the print related to the first set piece of 1740, Silici "Capo focarolo di Castel S. Angelo" on the print related to the second.

252 "A Franco Scardovelli, ed Anto Silici Focaroli," 64 pots; "Alli due Focaroli," 48 pots; "Alli due Fuocaroli," 48 loaves. "Lista di Spese diverse del mese di Lug.o 1769 ... [19 July] Al Focarolo che cadde nella pass.a Chinea [scudi] 4.10"; AC, I.A.493/115.

${ }^{253}$ AC, I.A.440/160: "Bilancio di Claudio Trifogli Erario dello Stato di Genazzano, e suo Ripartimento . . . E a di 31 Dec.re Scudi Venti, e [baiocchi] $15 \mathrm{mta}$ pagati li 4 Giugno pros.to à Gio: Angelo Carabella prò Monizioniere 
twenty-six caldrons of saltpeter and twenty of so-called acqua ricotta, a phrase synonymous with the second step of the production process. ${ }^{254}$ According to an eighteenth-century writer, a mixture of "clean water" and niter was first reduced by boiling and then evaporated into crystals; after a final boiling to remove all impurities, constant stirring under heat created a dry white powder with the consistency of flour. ${ }^{255}$ For producing the powder itself, workers were divided into three distinct groups: ten women, who collectively put in thirty-two work days at a wage of 10 baiocchi per diem; eight men, who collectively worked twenty-four days and were normally paid 15 baiocchi per diem; and seven forced laborers, who toiled fifty days at their collective task. These latter were likely lodged within the fortress itself; their desperate situation is highlighted by the name of one, "Agostino Sperduto," from whom only two days' work was required. One prisoner worked a full twelve days, the others only six or eight days. The forced laborers were paid 5 baiocchi per diem. Two other individuals helped: Giuliano Mosca "for grinding the powder" and Carabella, the overseer of the fortress. Each worked sixteen days, with Mosca paid 15 baiocchi per diem, Carabella 20. The wage differential between women and free men was somewhat reduced by the inclusion for women only of vinous payment, whose cash value increased their take-home pay by 5 or 10 baiocchi, depending on the number of full days worked..$^{256}$

Payment to Bruno Antonio Tamiotti, an illiterate cooper in Paliano, represented the final stage of production. ${ }^{257}$ Like many Roman merchants and artisans, he waited several years before having a bill drawn up for payment of goods and services rendered; the one in question was settled on 12 March 1761. A relative of Tamiotti by the name of Carlo signed for receipt of the payment. Today it is easy to forget the importance of wooden barrels in the

della Fortezza di Paliano per suo rimborso di tanti pagati per gnate impiegate in pistare, e granire la Polvere, Vino, Raffino di Salnitro, ed altro occorso per la Fabrica della Polvere," with attached note: "Foglietto d'Uscita a mta fatto da Me Claudio Trifogli Erario di S.E.P. nello Stato di Genazzano per tutto il mese di Giugno 1759; @ 4: Giugno d.o Pagato a . . Carabella . . Scudi Sedici, e [baiocchi]. quarantacinque mta e sono per saldo di tante giornate impiegate nella Fortezza della Terra di Paliano a far la polvere ... ; @ d.o Pagato al Sud.o Scudi Tre, e [baiocchi]. Settanta mta ... per raffino di tanto Salnitro grosso, e per aver ripassato N.o Venti Caldare d'acqua ricotta."

${ }^{254}$ AC, I.A.424/193: "Sig:re Claudio Trifogli . . . si compiacerà pagare al . . . Carabella pro Monizioniere Scudi due, e baiocchi venticinque se li pagano per haver raffinate numero sedici Caldare di Salnetro grosso alla rag:e di Giulio uno per Caldara, e n.o tredici Caldare di secondo raffino, chiamata acqua ricotta alla rag.e di un'grosso per Caldara, e con riceuta del med:mo Saranno bonati à vostri Conti qsto di 9 Giugno 1757.”

${ }^{255}$ As described in R. Jones, Artificial Fireworks Improved to the Modern Practice from the Minutest to the Highest Branches (London 1776) 1-2.

${ }^{256}$ AC, I.A.440/160, N.o pmo: “Per Barile uno, e mezzo di vino alla raggione di giuli nove, e mezzo il barile dispensato alle sud.e opere, un mezzo [boccale] il giorno [scudi] 1:42 1/2; E piu altri bugali quattro di vino per d.o lavoro [scudo] .11 1/2." The wine must have found other uses, for the amount disbursed does not correspond to the number of days the women worked.

${ }^{257}$ AC, I.A.454/136: "Conto del Sig.re Dom.co Ricci Aff.rio dello Stato di Genazzano per il Secondo anno dell'Affitto; E a di 31 Dec.re . . . [scudi] 1:83 li 12 Marzo à Bruno Antonio Tamiotti Tinozzaro per accommodatura de Barili, ed altro," with attached bill: "Conto di lavori fatti da M.o Brun'Antonio Tamiotti Tinozzaro in Paliano per Servizio della Fortezza di d.o luogo, a tutta sua robba, e fattura per Ordine del Illmo Sig.r Capitan Carlo Lauretti ... e sono li seguenti cioè l'Anno 1759; Inprimis per aver rimesso un cerchio alla tinozza per Agranar polvere [baiocchi] :10; E più rimessi quattro cerchi alli barili della polvere [scudo] :10; E più messe n.o tredici tavolette sopra li tappi delli barili della polvere per mandare a Roma per servizio della Achinea [scudo] :20; $E$ più rimessi due cerchi alle mezze botti per granar la polvere [scudo] :20; E più ritirati otto cerchi alle mezze botti, e quattro fondi, e li cerchi alli barili della polvere [scudo] :10; Io sotto di Com:e di Mro Bruno Ant:o Tamiotti dichiaro haver riceuto dal Illmo Sig:re Ab:e Dom:co Ricci Aff:rio Grale dello Stato di Genazzano per le mano [sic] del Sig.re Claudio Trifogli scudo uno e [baiocchi] ottantatre mta per saldo del sopradescritto attetstato in fede; [signed] Carlo Tamiotti di Com.e." 
economy of early modern Europe, yet these containers assumed numerous specialized forms designed to store and transport everything from grapes to caustic substances. The Encyclopédie dedicates eight engraved plates to the cooper's craft and the remarkable array of materials and implements proper to it. ${ }^{258}$ Tamiotti performed various tasks to facilitate the process of making powder and to prepare filled barrels for transport. He replaced hoops on half-barrels, on a tub used for grinding powder, and on the barrels for the powder. He removed old hoops and bottoms from these objects and set thirteen pieces of wood over the bungs of the barrels destined for Rome. The level of enumeration and detail may seem superfluous, but it had a purpose. If the powder did not catch, it was useless. Well-hooped casks with properly secured bungs ensured that the powder within would not seep out between the staves or at the opening. Such casks increased resistance to air, moisture, and other contaminating elements that could compromise the combustibles, whose leakage could also wreak considerable and uncontrollable havoc. ${ }^{259}$ An Italian proverb uses the cooper's art to evoke a vivid image, "dare un colpo al cerchio, e uno alla botte," or "to keep one's irons in the fire." The proverb serves as a leitmotif for all accounting records: detailed description attests to a job well done, serves as a reminder to the paymaster, and helps exact the desired sum. Tamiotti, the cooper in Paliano, got exactly what he requested.

Once prepared and properly packaged, the powder and saltpeter were transported to Rome. Overseer Carabella monitored incoming and outgoing goods with the same vigilance displayed by Ludovisi. He recorded the disbursement of 135 pounds of "fine powder" and 25 pounds of "refined saltpeter," sums that roughly correspond to the amounts the constable contractually agreed to supply. The 5-pound increase in the amount of saltpeter occurred because the number of "fountains on the set pieces" had increased. Thus Posi made a change in design that had larger consequences; communication with the fortress ensued, and the amount of saltpeter was altered. Giuseppe Ciancianelli, a literate carter, transported the substances to Rome. Significantly, the date of consignment, 16 May, proves that production began on 1 May, a full week before the firework masters signed their contract in Rome. ${ }^{260}$ More to the point, this and many other aspects of the preparations began six weeks before the constable had received notice from Tanucci to present the Chinea. The Roman prince, assuming that the rendering of homage would continue, had to organize his large and diverse staff in timely anticipation of the official mandate.

Ciancianelli transported the combustibles in the company of a group of soldiers; the dangerous nature of the cargo required such precautions. Arriving on 18 May, the caravan took two days to travel roughly $55 \mathrm{~km}$ from Paliano to the walls of the Eternal City. Aspects of the soldiers' activity in Rome can be documented. Antonio Montelli recorded payment on 21

${ }^{258}$ See Diderot and d'Alembert, 31 :s.v. "tonnelier."

259 "On doit ménager dans cet attelier un petit coin bien fermé, pour y mettre la poudre \& les matieres combustibles, qu'il faut conserver dans des barils \& des coffres bien fermés ... si l'on veut les conserver long-temp sans altération"; Diderot and d'Alembert, 1:s.v. "artifices."

${ }^{260}$ AC, I.A.441/166: “N.o 3 Sig:re Gio: Angelo Carabella . . . consegnarete al Vetturale Giuseppe Ciancianelli Decine Centrotrentacinque Polvere per servitio delli Fochi della Chinea per ordine del Illmo Sig.re Pietro Battisti, e con riceuta del med:mo Saranno bonati à vostri
Conti qsto di 16 Maggio 1759 [signed] Alfiere Camillo Luberti; Giuseppe Ciancianelli Mano p.pa; [signed] Sarg:e Gius.e Lauretti”; “N.o 15 Sig:re Gio: Angelo Carabella .. . Consegnarete al Vetturale Giuseppe Ciancianelli decine venticinque Salnetro raffinato . . . qsto di 16 Maggio 1759 [signed] Alfiere Camillo Luberti; Giuseppe Ciancianelli Mano p.pa; Io SottoScritto attesto qualmente il S.re Gio: Angelo Carabella pro Monizioniere hà dato decine cinque di piu di Salnetro $+[+$ di quello anno riceuto li Focaroli] per ordine del Sig.re Pro Battisti per alcune fontane accresciute alle Machine de fuochi artificiali qsto di et anno Sud.o Carlo Cap.no Lauretti Cecio m.a pp.a; [signed] Sarg:e Gius.e Lauretti." 
May to an errand boy from the Porta Maggiore, "for accompanying the powder that came from Paliano"; that point of entry is at one end of the via Prenestina. ${ }^{261}$ The soldiers spent the night of 18 May in Rome, receiving standard disbursements of wine and bread and a portion of oil from the Colonna on that day and the next. ${ }^{262}$ The eight soldiers divided a cash payment among themselves, which amounted to considerably less than the per diem wages of security guards in the piazza Farnese. ${ }^{263}$ The muleteer, too, received a modest payment. ${ }^{264}$

The firework masters Scardovelli and Silici acknowledged receipt of the powder and saltpeter in documents dating to 16 June, the same day that Tanucci addressed an official letter to the constable with the royal mandate to present the Chinea. Amounts much larger than what was contracted are recorded on the receipt, which suggests that it was only the amount disbursed in Paliano whose cost was subtracted from the firework masters' wages. ${ }^{265}$ The wording of the receipt states unambiguously that all the materials came from stockpiles in Paliano; the balance, provided at no cost to the firework masters, was needed to create fireworks displays of the desired scale. There is no accounting of how or when the extra powder and saltpeter were fabricated or procured. In any case, the substances were kept separate because saltpeter, heavier than powder, would otherwise have settled to the bottom of the barrel. From the time of disbursement to the time of ignition, the firework masters had twelve days to do their work. The accounting record provides no information about this process, as it fell within the competence of the contractors and was thus of no economic concern to the Colonna administration. ${ }^{266}$

Scardovelli put on the first night's show, Silici the second, but it is uncertain whether they worked as a team. Since they shared cash and in-kind disbursements, perhaps they stood at the head of one atelier in which supervisory tasks and even control of the decorative programs alternated. The arrangement of fireworks displays required a sense of timing and an ability to fashion a satisfying whole from a multiplicity of parts, qualities that could be likened to the direction of musical or theatrical performances. Describing the Chinea of 1758 , Grosley wrote admiringly that "the fireworks were discharged with all the intelligence and precision that distinguish Italian firework masters." ${ }^{267}$ The Encyclopédie outlines some of the precautions proper to pyrotechnic displays throughout Europe, which included covering the platforms of the armature with a mixture of earth and sand; in this way, fireworks that failed to rise or fell before the point of complete consumption would not ignite the wooden structures.

${ }^{261}$ AC, I.A.443/152: "al Novitio di porta Maggiore per la accompagno della Polvere venuta dà Paliano," no specific sum provided.

262 "A di d:o [18 May] per li Soldati di Paliano che sono venuti in roma colla polvere per Serviz:o de Fuochi della Chinea [boccali] :09; A di d.o per la Cocina Comune per li med.i [boccali] :01:2; A di d:o [19 May] per li Soldati di Paliano che sono venuti colla polvere [boccali] :08." "18=d.o [Maggio] Per n.o 8 Soldati di Paliano che anno portata la Polvere [pagnotte] 12;19=d.o [Maggio] Per li Soldati d.i [pagnotte] 14." "18=d.o [Maggio] per la Cena delli Soldati di Paliano venuti colla polvere [foglietta (of oil)] :1; 19=d.o [Maggio] per li Soldati Sudetti [foglietta] :1; AC, I.A.437/141.

${ }^{263}$ AC, I.A.443/155: “Alli Soldati di Paliano per haver' portato la Polvere per I fuochi [scudi] 2:05.”
${ }^{264}$ AC, I.A.443/152: "Al Mulat.re per porto della Polvere [scudo] .30."

${ }^{265}$ AC, I.A.436/24: “Io Sottosc.to hò ricevuto ... libre Seicentosessantanove, e mezza Polvere, e libre Novantasette Salnitro per doverlo buonificare alla med.a Eccza alla Ragg.e di Bajocchi Dieci=la libra, e questa à Conto delli Fuochi artificiali da farsi la sera delli 29: del corr.te Mese in occasione della publica Rappresentanza della Chinea. In fede qsto di $16=$ Giugno 1759 ... [signed] Antonio Silici." Scardovelli signed a similar receipt.

${ }^{266}$ For the making of fireworks, see Diderot and d'Alembert, 22:s.v. "artificier," pl. I.

${ }^{267}$ Grosley, 3:54. 
Many buckets filled with water were kept nearby, which in case of need would be wielded by "active people" who wore leather aprons to reduce the risk that their clothes would ignite. Additionally, the text suggests that in "the substructures or pedestals of statues and groups," the fire brigade could find a place to shield itself from the fireworks that exploded in great number above. ${ }^{268}$

Scardovelli procured large amounts of torches and fiaccole and himself rented "frying pans" to place on top of the latter. He would have wanted to arrange these stable lighting fixtures personally, since they bore a relationship, in terms of design and composition, not only to the ephemeral structure that supported them, but to the discharged fireworks. On the other hand, during the displays, it was considered desirable that firework masters remain out of sight, in a pattern analogous to the many hidden stairways and corridors found in palaces and villas, which enabled servants to move about without being seen by the noble company. ${ }^{269}$ Ludovisi notes that Scardovelli had procured illuminations for both evenings, another indication that he and Silici worked to some extent as a team; indeed, Silici had a relative in the festival industry who had supplied ephemeral lighting fixtures to the Spanish embassy in Rome in $1752 .{ }^{270}$ Ludovisi also engaged the services of four men for the emplacement of torches and fiaccole. The cash payment they divided among themselves was equivalent to a per diem wage of .30 scudo, 16.67 percent greater than a security guard's wages; they also received portions of wine and bread. ${ }^{271}$ As we have already seen, basket-maker Pizzitutti supplied four baskets with handles that were designated "to carry paper lanterns and fiaccole." 272 In multiple trips impossible to enumerate, the four men distributed the individual torches and poles (each weighing, respectively, 3.95 and 7.17 Roman pounds) according to the dictates of Scardovelli. The task was of such proportion that a special payment is recorded to the festival-hangers for their help. ${ }^{273}$ The manipulation of extremely dangerous

${ }^{268}$ See Diderot and d'Alembert, 1:s.v. "artifices." Grenadiers at the Chinea could also keep vigil: "Sig.r Pietro della Bitta . . . potrà dare alli due Granattieri esibitori del presente boccali Sedici Vino per aver smorzato l'incendio alla Seconda machina de Fuochi La Sera de 29 pas.to in mia presenza f q.o di 2 Lug.o 1754 [signed] Pietro Battisti"; AC, I.A.394/200.

${ }^{269} \mathrm{~A}$. Gerardi, Relatione del solenne apparato Fatto ... . Nella Chiesa ... del Giesv di Roma in occasione delle Quarant'bore (Rome 1640), quoted in Fagiolo dell'Arco, 314: "e scale, per le quali con bell'ordine, e sicurezza nell'immensità della vasta macchina più di quaranta persone stauano distribuite illuminando, e facendo la sentinella al suo posto, acciò non seguisse danno alcuno, e niuno di questi fù mai veduto dagli spettatori"; quoted passage also in F. Matitti, "La festa come 'laboratorio' del Barocco," in Fagiolo, 1:85; see also n. 132 above. Conversely, that "the pyrotechnists had no room" was a cause for reproach in the duc de Cröy's account of a set piece built in Paris in 1782; quoted trans. in Salatino, 20.

${ }^{270}$ AC, I.A.443/152: "A Franc.o Scardovelli per Saldo di Suo Conto [scudi] 55:12 1/2." The attached bill reads: "Io Sotto Scritto fo fede come il Sig.re Francescho Scardovelli a dato ... in Ocasione delli fochi [per] la Cinea li dui Sere. . . la Sotto Scritta Robba come Apresso;
Fiacole n.o 230 di Peso \#1650; Torcie n.o 110 di Peso \#435; In tutto \#2085." Ludovisi next carries out a multiplication, valuing each pound of substance at .025 scudo, which yields 52:125 scudi. To that figure he adds 3 scudi "per Nolito delle Solite Padelle," bringing the total to 55.125. "Relacion de los pagamentos hechos de orden del ... Cardenal Portocarrero . . pagados ... por D.n Francisco Bermudez de Sotomayor, Tesoriero extraordinario de S.M. en esta Corte de orden dela de España por el importe delos gastos ocurridos en este Ministerio ... desde 1.o de Mayo hasta fin de Agosto de 1752 . . . Pagados à Joseph Silici por Placas de pez, que dio en ocasion de diversas Luminarias hechas en el Real Palacio hasta todo Agosto de 1752 [scudi] 14:50"; AGS, SE 5132 (insert in a letter from Rome of Cardinal Portocarrero to Joseph de Carvasal y Lancaster dated 9 Nov. 1752).

${ }^{271}$ AC, I.A.437/139: "Per 4 Omini che Metono le fiaccole [scudi] 2:40." "A n.o 4 Omini che mettono le Fiaccole," 8 jugs; "A n.o=4 Omini che mettono le fiaccole le due Sere," 16 loaves.

${ }^{272}$ See n. 236 above.

${ }^{273}$ AC, I.A.443/152: “Alli festaroli per L'assistenza prestata per le Torcie [scudi] 4:10." At other times, festival-hangers were charged with emplacing the fireworks, 
materials required that the firework masters' craft be carefully regulated, yet, in this case alone among all artisans, not according to the dictates of Posi. Artificial fireworks displays kept firework masters at the top of their craft during the permanent peace that prevailed at Rome, a condition that bureaucrats in the foreign office at Versailles attributed to the concerted political will of their king and the holy Roman emperor. ${ }^{274}$ The political impotence of Rome was held as an article of faith in French diplomatic and governmental circles in the eighteenth century. ${ }^{275}$

\section{CleANing Up}

The piazza Farnese was remarkably altered in the days between 15 May (when the security guards began their round-the-clock vigils) and the evening of 29 June (when the last fireworks had exploded, and the last happy stragglers left to go home). From an active and deafeningly noisy work site, the square became an open-air theater into which representatives from all but one level of Roman society were compressed. Only the pope was absent, or only briefly (and on pretext) present. The iced confections in the Farnese palace, the concerts in the square, the laughter, chatting, and gossip, the blinding fireworks-none of these was his to enjoy. Protocol dictated that the pope could not receive homage from the king of the Two Sicilies and then become the guest of the ambassador extraordinary who rendered that homage. The assembled guests and the varied public in the square and streets celebrated the power of an absent monarch, whereas the pope, in the act of receiving homage, slightly diminished that power. It was also simply not considered seemly for the pontiff to appear at politically motivated ephemeral events, for his presence could be construed as showing undue favor toward one crown at the expense of others. ${ }^{276}$

Considerable effort was required to return the piazza Farnese to its normal state. The first things needed were brooms, both besoms and brooms for sweeping carpets. The former, made of branches of heather or birch tied to a handle and used to sweep stone floors clean, were put to use on the stairways, corridors, courtyard, and service rooms in the Farnese palace. The broom binder Giovanni Battista Rota provided the Colonna with six "white brooms

not merely torches: "Conto Delli Lavori fatti . . . nelle due Machine ... nell'anno 1756 . . . E per aver messo tutto il foco artifiziale indove commandavano li focaroli con Scale Lunghe à tutte due le Machine con sei Ommeni pr Ordine del Sig.re Pietro Batisti”; AC, I.A.417/227.

274 "Le Sieur évêque de Laon est instruit des circonstances, et des suites de cette guerre [the Seven Years War] et il sera successivement informé des événements ultérieurs auxquels elle donnera lieu. L'Italie est heuresement à l'abri des calamités qui en sont inséparables et c'est particulièrement au Roi que cette partie de l'Europe doit la tranquilité dont elle jouit. En effet, Sa Majesté a eu dans les engagements qu'elle a pris et aura également dans ceux qu'elle pourra prendre encore avec la Cour de Vienne l'attention de pourvoir à la conservation du repos en Italie et à prévenir par une sage prévoyance, les incidents qui pourraient le troubler à l'avenir"; "Mémoires pour servir d'instruction au Sieur de Rochechouart ... allant à Rome en qualité d'ambas- sadeur extraordinaire du Roi aupès de nôtre Saint-Père le Pape," redacted at Versailles, 3 July 1757, quoted in Hanoteau (as n. 44) 370. Cf. a passage in a letter of Benedict XIV to Cardinal Tencin: "the two armies are ruining the States of the Church. The Spaniards are the authors of our misfortune, but the Austrians expect to live entirely at our expense"; quoted in Pastor, 35:111.

${ }^{275}$ Paris, Archives du Ministère des Affaires Étrangères, Correspondance politique, Rome 705 (draft of a letter from Versailles to Polignac dated 2 Aug. 1729): "Quoiqu'il soit tres vrai que les deliberations te ta Cour ny meme les resolutions de la Cour de Rome ne decideront rien pour les partis que les principales Puissances de l'Europe jugeront a propos de prendre par rapport aux Etats destinez a D. Carlos, il sera toujours bon que vre Em.ce veüille bien observer ce qui se passera la dessus et qu'elle en informe le Roy. Nous n'avons encore rien de positif d'Espagne."

${ }^{276}$ See Moore, 606. 
from Rieti," ten normally sized brooms, five smaller brooms, four large broomsticks, and several skeins of twine used to tie the twigs together if they came loose. ${ }^{277}$ In his 1758 bill, Rota specifies that Rieti brooms were used "for the apartment" (where there may have been carpets), and other brooms and brushes "for the butler's pantry." 278 Record of the hands that wielded these brooms is also preserved. Felice Antonio Giulietti, "retired sweeper," was paid in cash and kind, as were the constable's "secret sweepers," Matteo Taliani, and Filippo Sciamuin. Quartermaster Ludovisi dated a chit for bread and salami (companatico) to 26 June, indicating that the team was busy before that date. ${ }^{279}$ Taliani and Sciamuin received separate cash payments equivalent to fourteen days' work for each, at the rate of .20 scudo per diem..$^{280}$ Numerous portions of wine to one or the other (or both) suggest that they piled up chits corresponding to separate, yet unnamed, tasks.

Coppersmith Bernardo Agostini had consigned to Taliani thirty-six screens for the apartment in the Farnese palace. ${ }^{281}$ The sweeper stood at the head of a team of eight, as is demonstrated by an in-kind disbursement. ${ }^{282}$ The scale of the cleanup is suggested by a separate cash payment of 60 baiocchi to a man "who swept the portico and the stairs of Palazzo Farnese." 283 Even the concierge, who had already received generous recompense for his many duties, received extra money for having had the trash removed from the palace courtyard. In his petty-cash report of Chinea-related expenses, Orlandi apparently had no written record of the activity of the concierge, who nonetheless considered it worth his while to make the trip to the Colonna palace on 24 August, nearly two months after the festivities, assuming (correctly) that his extraordinary work constituted a good basis for exacting payment. ${ }^{284}$

Dismantling the temporary butler's pantry, which contributed to the piles of trash in the courtyard, was supervised by the constable's French butler, Dorelli, who hired ten porters for the purpose at the rate of 60 baiocchi per diem. ${ }^{285}$ These porters must have been involved in the task of returning silver plate and other objects to the Colonna compound in the piazza SS. Apostoli. The festival-hangers returned to the apartments of the Farnese palace to dismantle

${ }^{277}$ AC, I.A.436/105: "Conto di Robba diversa data dà Gio. Batta Rota ... nell'Anno 1759; E più n.o =6 $=$ Scope bianche di Rieti à [baiocchi] =6=l'una sono [scudo] :36/ :36; E più Scope di Zeppi [baiocchi] $=10=$ [scudo] $: 10 /$ $: 10 ;$ E più Scopini di Zeppi [baiocchi] $=5=$ [scudo] $: 05 /$ $: 05 ;$ E più n.o =4= Manichi grossi dà Scopa [scudo] :10/ :06; E più Gniummeri [number is illegible] di spago [scudo] :08/:08."

${ }^{278}$ AC, I.A.427/80: “Scope di Rieti per l'Appartamento," "Scope di Zeppe per la Credenza," and "Scopini per la credenza il tutto con ordine del Sig.re Alberto Disp:re.”

${ }^{279}$ Salaries for the month of June 1759 are recorded for "Matteo Taliani Scopatore Segreto [scudi] 3," and "Felice Antonio Giulietti [scopatore] giubilato [scudi] 2:50"; AC, I.A.443/145. "A Felic'Antonio Giulietti," 6 jugs; "Felice Ant:o Giulietti Scopatore giubilato," 12 loaves; "A Matteo Taliani, e Filip:o Sciamuin," 8 jugs; "Alli med.i," 12 jugs; "Alli med.i," 6 jugs; "A Matteo Taliani," 6 jugs; "Al Sud.o," 10 jugs; "A Filippo Sciamuin'," 6 jugs; "Al Sud.o," 2 jugs, for a total of 50 jugs. "Alli Scopatori Segreti," 24 loaves; "Sig.re Alberto Ludovisi Dispenziere potrà dare à Matteo Taliani, e
Filippo Sciamuini Pagnotte Sedici, e libre Sei di Companatico in occasione dlla Chinea di Corr.te anno, qsto di 26 Giug.o 1759 [signed] Pietro della Bitta"; "A Filippo Sciamuin," 4 loaves.

${ }^{280}$ AC, I.A.443/152: “A Filippo Sciamuin', e Matteo Taliani per giornate 14 per ciasched.o [scudi] 5:60.”

${ }^{281}$ For Taliani's receipt of the screens, see n. 73 above; for his having cleaned the apartment in the Farnese palace in 1754 before the receptions, see $n .79$ above.

282 "A Matteo Taliani per il beveraggio di N.o 8 Omini," 20 loaves.

${ }^{283}$ AC, I.A.443/152: "Ad Un huomo, che hà Scopato Il Portico, e Scale del Palazzo Farnese [scudo] .60.”

${ }^{284}$ AC, I.A.443/198: "Al Detto [Guarda Portone del Palazzo Farnese] disse per aver fatte portar' via L'Immonditia dal Cortile di detto Palazzo [scudo] .20.”

${ }^{285}$ AC, I.A.443/152: "pius diechi fachini per Lespichio a paoli 6, al gorno importa [scudi] 06:-." 
and put away, "each thing in its place," what they had earlier set up, namely, "baldachins, curtains, chandeliers, sconces, copper screens, and other things." It was necessary to replace thirteen windows in the palace that were broken by projectiles. The glazier Rinaldi performed those repairs on 2 July 1759 . He received what he requested for this service, which indicates that the cost of this frequently occurring activity was well established; his full reimbursement here stands in contrast to the separate and audited bill he presented for other Chinea-related expenses. ${ }^{286}$

Several activities related to the set pieces and the physical fabric of the piazza Farnese can be documented. Simplest to understand is a payment that quartermaster Ludovisi made to the "sweepers of the streets." 287 Cleanup would have involved removing painted canvas and paper and other parts of the decoration (such as plant materials) that could not be saved. The crew was probably instructed to lend a hand in salvaging those parts of the set pieces that could be reused, such as parts of the wooden armature or the sculptural armatures to which Grossi had added "heads, hands, and feet." The bill of tinsmith Bassetti provides information about the dismantling of the fountains. He states that he went "some days after" the last fireworks to remove the pipes of the second set piece. Before he could start his work, the square needed cleaning and the structure dismantling, a job that took two men one day to complete. In order to effect any plumbing work, the source of water had to be temporarily shut off. Bassetti's men did this and soldered one patch of lead "above the mouth of the large conduit." He left two large pipes in a trench beneath street level "for other occasions." The necessity of having the masons dig that trench over again was thus avoided; what Bassetti also takes for granted is that the presentation of the Chinea would occur again and that the piazza Farnese would continue to be the site for its public unfolding. With typical wording, he cites "much time and labor" to justify the charge for turning the water on again. His last entry points to the services of a porter, who had to "carry back all the above-mentioned pipes." Bassetti specified that this expense came from "personal funds," as though that were atypical. As was typical, the porter's services were not disputed, and Bassetti received a full reimbursement for them, the only one of four expenses not cut by Posi. ${ }^{288}$

Bassetti's articulated bill and Posi's cuts embody the mosaiclike complexity of artisans' and artists' tasks, all of which was overseen by the constable's vigilant domestic staff. Each group brought with it an experience of past presentations that structured and renewed expectations in 1759, and that made the unfolding and interlocking activities of many individuals come together, despite the unusual rainstorm that threatened complete disaster. After the structures were dismantled, the broken panes of glass replaced, the permanent fountains of the square restored to working order, the trash removed, and the ambassador extraordinary's coat of arms taken down from the façade of the royal palace, one of Rome's great urban spaces was restored to normalcy. Home to 150 people from a wide swath of Roman society, the Farnese palace, too, returned to its patchwork of daily rhythms. The lead pipes left out of sight below the surface of the street held, to be sure, some water, but also the promise of future transformations, whose multiple delights the city and its residents eagerly awaited.

${ }^{286}$ AC, I.A.437/141: "Alle Fenestre dell'App.to del Pal.o Farnese, per n.o 13 vetri novi [scudo] .65." For .05 scudo as the "prezzo ordinario" for "Vetri sani l'uno," see Scavizzi, 134. For Rinaldi's audited bill, see n. 75 above.
${ }^{287}$ AC, I.A.437/139: "per li Scopatori delle Strade [scudo] .90."

${ }^{288}$ For dismantling the structures, asking price, 2.15 scudi, payment, 1.65; AC, I.A.442/186. 


\section{Paolo Posi, IL Signore architetto: The Missing Link}

In each of the twelve months of 1759 , Paolo Posi signed for a salary of 4 scudi with his own hand. Employees in the Colonna household were divided into distinct groups: "gentlemen attendants" (among whom was Antonio Saracinelli, Lorenzo Colonna's chamberlain), "ministers" (among whom Posi), "pages," "chamber assistants," "officials," "grooms," "lackeys," "stable," "boys in service," "diverse individuals," and "women." 289 In June 1759, two Frenchmen-Pietro Leroux, a roaster of meat, and François Glairoy, "first cook" - both received 9 scudi. ${ }^{290}$ In 1738 , a factotum (facchino) in the Farnese palace earned 4 scudi a month. ${ }^{291}$ And in 1759 , even the security guards in the piazza Farnese, whose services were required every day, would have earned 7.75 scudi, nearly twice Posi's salary. However important their job was, it did not require much professional training. In comparison to others in the constable's household staff, Posi's annual salary was mediocre, comprising 48 percent of what Fuga, architect of Charles VII, earned in 1759. ${ }^{292}$ Johann Joachim Winckelmann, librarian to Alessandro Cardinal Albani, earned 10 scudi per month "without making a stroke of the pen for [Albani] or in the library." 293

Inscriptions on etchings related to the set pieces of 1751 identify the Sienese-born Posi as "architect of the most excellent Colonna family." These structures represent his first Chinea designs, and he continued to provide designs until 1774, two years before his death. ${ }^{294} \mathrm{On}$ extremely familiar terms with Benedict XIV, in 1753, 1754, and 1755, Posi himself enjoyed the honor of explaining the iconography of the set pieces to the pontiff, presenting him at the same time with etchings "in a silver basin [bacile d'argento]." 295 On the 28th, the pope stopped his carriage on the way to St. Peter's; on the 29th, he visited the piazza Farnese after adoring "the Most Holy Sacrament" exposed in the (relatively) nearby church of S. Giovanni dei Fiorentini. Luigi Vanvitelli, no admirer of Posi, ascribes some of latter's success to the support of Colonna house-accountant Francesco Maria Giuntotardi, which points to the

${ }^{289}$ AC, I.A.443/145: "Rollo del Mese di Giugno 1759 Della Fameglia dell'Eccmo Sig.re Gran Contes.le D. Lorenzo Colonna, di Pane, Vino, e Denari ... Ministri ... Paolo Posi Architetto [scudi] 4 Io Paolo Posi Arch.o o riceuto."

${ }^{290} \mathrm{AC}$, I.A.443/145: "Pietro Lorù Rosticciere compresovi la piggione [scudi] 9"; he signed his name "pietro Leroux." A manuscript addition at the payment for February 1759 reads: " +4 pagnotte e 3 fogliette di vino ogni giorno," in-kind disbursements that added the equivalent of 2.15 scudi to his monthly salary; AC, I.A.443/46. "Fran.co Glairos pmo Cuoco coll'obbligo di mettere in Tav.la [scudi] 9"; he signed his name "François Glairoy"; AC, I.A.443/46.

${ }^{291}$ See n. 23 above.

${ }^{292}$ AS, AER 1079: "Bilancio dalli 16. Feb.o 1759, à tt.o li 15. Mag.o d. Anno ... Nota delle Spese occorrenti per la R. Casa Farnese in Roma, in Aprile, Mag., e Giug. 1759 ... Uscita ... @_detto [27 July]-[scudi] Cinquanta $=$ mta pag. al Sig.re Cav.re Ferdinando Fuga per la solita ricognizione di sei mesi à tt.o Giugno pros.to accordatale da S.M. à rag.e di [scudi] $100=$
l'Anno, come per Mandato e ricevuta n.o 102 [scudi] 50-."

${ }^{293}$ Winckelmann, letter from Rome dated 12 Dec. 1759 , in Johann Joachim Winckelmann Briefe, ed. W. Rehm and H. Diepolder, vol. 2 (Berlin 1954) 57-58.

${ }^{294}$ The "invention" of the set pieces in 1775 is ascribed to Giuseppe Palazzi: "inventate dal Sig. Giuseppe Palazzi Romano allievo, e Giovane attuale del celebre Sign. Cav. Paolo Posi Architetto, della prelodata Ecc. Sua, e che lodevolmente si sostituisce così in questa, come in altre occasione al predetto suo Maestro, già da tre anni a questa parte infermo"; Chracas, n.s. no. 52, 1 July 1775,14 .

${ }^{295}$ For the pope's visit in 1753 , see Chracas, no. 5613, 7 July 1753 ; in 1754 , no. 5769,6 July $1754,10-11$; in 1755 , no. 5925 , 5 July $1755,5,14-15$. On 28 June 1756 , “il Sig. Pietro Battisti, Sopraintendente Generale dell'Eccma Casa Colonna," presented "le stampe in rame di amendue le machine in un bacile d'argento"; Posi is not mentioned in this context. On the next day, the pope stopped his carriage to look at the second set piece; Chracas, no. 6081, 3 July 1756, 10, 21. 
importance in architects' careers of powerful personal acquaintances. ${ }^{296}$ Over the course of more than two decades, thanks to the festival of the Chinea, Posi is mentioned more than any other architect active in eighteenth-century Rome in the Diario ordinario, the newspaper better known as "Chracas," after the publishing house that edited it.

Earlier in his career Posi worked for highly placed members of the curia. In the 1740s he was the architect of Monsignor Martino Innico Caracciolo, visitor apostolic of foundling hospitals in the Papal States, for whom he designed and built a conservatory at Narni and remanaged another in Viterbo. In September 1741, in one of the churches of the Neapolitan community in Rome, he designed an ephemeral display that won him great praise in the newspaper. ${ }^{297}$ In that same year, he was commissioned to build a chapel to St. Michael Archangel in S. Maria dell'Orazione e della Morte. ${ }^{298}$ In the second half of the 1740s, he also designed a cenotaph in the church of S. Agostino, remanaged a chapel dedicated to the Virgin and the doctors of the church in SS. Ambrogio e Carlo al Corso (the Milanese national church), and rebuilt the tribune at S. Maria dell'Anima (the German national church) ${ }^{299}$ In 1754 he helped oversee the sculpture collection of the Vatican Palace; at that time, Alessandro Albani exchanged letters with Posi in the hope of securing assistance for the English sculptor Joseph Wilton, who wanted to obtain a plaster cast of the Apollo Belvedere. ${ }^{300}$ In August 1756, Posi was named architect of the "Sacred Apostolic Palaces," whose master of the household was Monsignor Marcantonio Colonna, the constable's brother; here, too, a family connection cannot have hurt his advancement. ${ }^{301} \mathrm{He}$ has gone down in often-anonymous infamy as the architect who altered the attic zone of the Pantheon between 1757 and 1758, immediately after

296 "Quanto mi dispiaccia l'affare di Tommaso Bianchi in danno del Signore Carlo [Murena] non ve le so spiegare, riflettendo che non dovea essere, una volta $\mathrm{e}$ quando però il Signore Carlo l'avesse richiesta, perché se la richiesta non l'avesse fatta non vi sarebbe tanto che dire perché quella birba del Giuntotardi Computista sempre à portato persone contro me; egli à portato il Posi et ora averebbe potuto fare lo stesso con il Bianchi, et il bonus vir non à saputo distinguere le persone"; Strazzullo, 2:314-15 (letter from Caserta dated 17 March 1759).

${ }^{297}$ Chracas, no. 3768, 23 Sept. 1741, 10-11: "Per la festa correva Martedì di S. Gennaro Protettore della Città di Napoli, nella Chiesa dello Spirito Santo della Nazione Napoletana ... . Il sontuoso apparato, che ornava in tal congiontura tutta la Chiesa, era disposto e lavorato con tale industria, e perfezzione, che per verità può dirsi essere stato uno de'più vaghi, ricchi, e maestosi siasi veduto, corrispondendo in tutto alla grandiosità della festa, alla qual sopraintendenza fu deputato Monsign. Martino Innico Caracciolo, che ne diede la commissione, riguardo all'apparato, al di lui Architetto Sign. Paolo Posi Romano."

${ }^{298}$ Chracas, no. 3768, 23 Sept. 1741, 15: "La divozione di varj Confratelli del numero dell'Archic. di S. Maria dell'Orazione, Compagnia della Morte, avendo fatto edificare a proprie spese, nella stessa Chiesa della Morte, la Cappella dedicata a S. Michele Arcangelo con disegno dell'Architetto Sig. Paolo Posi, in oggi, che si vede terminata, è riuscita, benche piccola, una delle vaghe Cappelle, che adornano queste Chiese di Roma."

${ }^{299}$ The monument to Giuseppe Renato Cardinal Imperiali (died 1737) was sculpted by Pietro Bracci. For an account of Posi's presence in the church in the week before 28 Aug. 1745, at which time he explained the newly uncovered monument to Benedict XIV ("ebbe l'onore di darne qualche piccolo ragguaglio"), see Chracas, no. 4380, 21 Aug. 1745, 22, transcribed in Mallory, 170; for an illustration, see Kelly, 612. For SS. Ambrogio e Carlo al Corso, see Chracas, no. 5118, 9 May 1750, transcribed in Mallory, 173; for S. Maria dell'Anima, see Chracas, no. 5196, 7 Nov. 1750,15 , transcribed in Mallory, 173. See also Contardi and Curcio (as n. 21) 422-24; A. K. Placzek, ed., Macmillan Encyclopedia of Architects, 4 vols. (New York 1982), s.v. "Posi, Paolo"; W. Buchowiecki, Handbuch der Kirchen Roms: Der Sakralbau in Geschichte und Kunst von altchristlicher Zeit bis zur Gegenwart, vols. 1-3 (Vienna 1967-74), passim; Dizionario enciclopedico di architettura e urbanistica, 6 vols. (Rome 1968-69), s.v. "Posi, Paolo."

${ }^{300}$ See F. Noack, "Des Kardinal Albani Beziehungen zu Künstlern," Cicerone 16 (1924) 410.

${ }^{301}$ Chracas, no. 6096, 7 Aug. 1756, 15: "Per la seguita morte del Sig. Pietro Ostini Architetto de Sagri Palazzi Apostolici, dal Sig. Cardinale Pro-Maggiordomo è stato prescelto in suo luogo Architetto de medesimi Sagri Apostolici Palazzi il Sig. Paolo Posi Archietto dell'Eccma Casa Colonna." 
the repair and cleaning of the hemispherical vault ${ }^{302}$ A recent study has shed light on Posi's catafalque designs. ${ }^{303}$ On Wednesday, 14 March 1759, he set out for Venice to supervise work on the Villa Farsetti in Sala, returning to Rome in time to supervise the Chinea. ${ }^{304}$

Posi's presence in the context of the Chinea is confirmed by the receipt of two barrels of wine; his apprentice Palazzi received half a barrel. ${ }^{305}$ Posi had at least one personal servant who obtained a small payment from Andreini. ${ }^{306}$ On 20 July the architect was reimbursed for unspecified out-of-pocket expenses "made in occasion of the two set pieces for the presentation of the Chinea." ${ }^{307}$ On 27 July 1759, he obtained a cash payment of 50 scudi for his Chinea services. ${ }^{308}$ That sum reflects earlier practice, that of 1754 , for example, when "a customary recognition" was granted to Posi "for the two drawings and for assistance." 309 All things considered, rather few traces of Posi's activities can be found in the accounting records. Only the painters' contract of 1759 names him and his profession explicitly. In the same year, due to adverse weather conditions, the painters followed Posi's orders as they completed a campaign of repainting. Following similar orders, the turner Faggi supplied functional and decorative elements for both set pieces, and the festival-hangers put in place the brightly colored canopy of the second.

In his bill, the tinsmith Bassetti writes that he followed the orders of "Sig.re Pietro Battisti Superintendent, and of Sig.re Pauolo Posi Architetto." The presentation of the Chinea was a recurring event in the Colonna household. Over the years, the constable's staff had become experienced at orchestrating the many activities the presentation required, to such a degree that the Chinea became a routine. Pietro Battisti (or his predecessor, successor, or surrogate) could dispatch and delegate much of the work. In many ways, Posi's name should occur

${ }^{302}$ For Posi's alterations, see Buchowiecki (as n. 299) 2:677-78. The date 1747 is provided in C. Fea, L'integrità del Panteon rivendicata a Marco Agrippa, 2nd ed. (Rome 1830) 8, repeated in Buchowiecki, but contradicted by a newspaper account: "è stata commessa al Sig. Paolo Posi, Architetto del Sagro Palazzo Apostolico, la sollecita ristaurazione dell'interno della suddetta Chiesa, e particolarmente dell'Attico, in conformità del disegno del detto virtuoso Architetto già formato, e che si và di già eseguendo"; Chracas, no. 6195, 26 March 1757, 11 (see also Chracas, no. 6132, 30 Oct. 1756,8$)$.

${ }^{303}$ See Kelly.

${ }^{304}$ Chracas, no. 6504, 17 March 1759, 15: "In quella mattina istessa di Mercordì partì colla diligenza delle poste il Sig. Paolo Posi Architetto de'Palazzi Apostolici, alla volta di Venezia, ad effetto di accudire colà al compimento della nuova fabrica, che vi fa costruire il Sig. Abb. Farsetti Nobile Veneto." For a letter of Posi from Venice dated 30 March 1759 addressed to Girolamo Cardinal Colonna, see AC, II.CQ, pacco 4. For Posi's greenhouse projects for the Villa Farsetti, see M. Azzi Visentini, L'orto botanico di Padova e il giardino del Rinascimento (Milan 1984) 132-33; for his having obtained a plaster cast for Farsetti, see L. Lewis, Connoisseurs and Secret Agents in Eighteenth-Century Rome (London 1961) 170.
305 “Al S.re Paolo Posi,” 64 jugs; “Al Giovane dell' Architetto," 16 jugs.

${ }^{306}$ AC, I.A.443/152: "Al Serv.re del S.re Paolo Posi Architetto," [scudo] .30."

${ }^{307}$ AC, I.A.443/178: "A Paolo Posi per Rimb.o di Spese per L'Achinea [scudi] 3.20.”

${ }^{308}$ AC, I.B.49, fol. 873 right: "E a di $27=$ detto [July] [scudi] 50=mta in cro al sudetto [Sag: Monte di Pietà] pagati à Paolo Posi Architetto di S:E: per la solita ricognizione delli due Disegni, ed assistenza prestata alle due Macchine de Fuochi."

${ }^{309}$ AC, I.A.400/210: “Sig. Fran.co Andreini . . p potrà pagare al Sig.re Paolo Posi Architetto .. . Scudi Cinquanta $=\mathrm{mta}$, che glieli fà pagare la nomata Eza per la solita Ricogniz.e delli due disegni, ed assistenza prestata nelle due Machine de fuochi artificiali che fà fare S.E. Pne, in occasione della publica rappresentanza della Chinea dl Corr.e anno restando con il pnte pagamento intieramente saldato, e sodisfatto di quanto potesse dal sud.o Eccmo Sig.re G. Contestabile e non altrimenti Che con ricevuta Di Casa Colonna li 27 Giugno 1754 / [signed] Pro Battisti / Ho riceuto li sud.i Scudi Cinquanta mta in Fede q. di 17=Lug.o 1754 / [signed] Paolo Posi Arch:to." An analogous payment exists from 1755; AC, I.A.402/158. 
infrequently in the accounting records. Among other things, Posi sat at his desk, thought, and read books and other sources of information about ancient and medieval history, myth, literature, and contemporary events. He saw (or at least heard of) other festive manifestations in Rome and elsewhere and appears to have used those experiences for inspiration. ${ }^{310}$ He consulted his collection of drawings and prints after antique and contemporary monuments. He sketched in graphite, measured and squared, drew in ink, and applied color washes. ${ }^{311} \mathrm{He}$ fashioned inscriptions for the Chinea prints and performed many other tasks for which there was usually no need to solicit reimbursement or engage the services of others. Moreover, he was a salaried employee and thus unlikely to be reimbursed for all but the most extraordinary expenses. By employing a house architect in the first place, the Colonna benefited from Posi's technical, intellectual, and creative skills as he carried out his Chinearelated tasks.

Posi, as we already know, prepared highly finished presentation drawings for the constable's approval. Other drawings, whether copies or even scaled details, likely served as patterns for the numerous artisans who worked on the set pieces, not all of whom were on site. Structures that the architect had originally conceived as "first" and "second" set pieces were sometimes reversed, according to criteria that are mostly lost to us. Was it the constable who changed Posi's mind, or some of those who gathered in the offices of the Colonna palace to sign their contracts? In 1758 the reasons for reversal are perhaps easier to infer. Benedict XIV died on 3 May 1758, so Posi must have conceived and executed his presentation drawing for the "first" (in fact, second) set piece before that point, as the pontiff is mentioned in the draft inscription (fig. 30). Although the pope had long been ailing, the wording of this draft inscription also assumes that the Chinea would be presented, as normal, on the vigil of the feast of Sts. Peter and Paul, which did not turn out to be the case. ${ }^{312}$ Plans were afoot two weeks after his death "so as to have all the work done for the election of the new pontiff." 313 What became the second set piece indeed represents a pagoda with real (albeit rented) bells (fig. 23). This structure would have created-in the piazza Farnese in Rome, of all places-an effect much more visually and aurally striking than the obelisk that constitutes the dominant motif of what became the first set piece

${ }^{310}$ For texts that speak to a widespread familiarity with Bacchus, see n. 174 above. A few days before the unveiling of the set pieces of 1758 , architect Francesco Nicoletti built an ephemeral structure in the courtyard of the Collegio Romano that bears comparison to the second set piece of 1759: "ed acciò la funzione seguisse con la maggior magnificenza fecero ridurre quell'ampio cortile a forma di una Deliziosa, ornata con fontana, parter, vasi, colonne, pilastri, e statue, e con cocchi di viti, e fiori nella sua sommità all'intorno ricoperta. Prima di ogn'altra cosa vedevasi nell'entrare il parter rabescato di verde busso, con fontana di acqua corrente nel centro, e tra gl'altri ornati nel mezzo la Fenice impresa de Sig. Accademici Ravvivati, con altre fontane collocate in mezzo agl'archi, e con balaustre abbellite con vasi di agrumi"; Chracas, no. 6423, 9 Sept. 1758, 9-10; see also Chracas, no. 6426, 16 Sept. $1758,15$.

${ }^{311}$ Drawings by Posi related to Chinea set pieces exist: 1755, 1 (Rome, Biblioteca dell'Istituto nazionale d'archeologia e storia dell'arte [BINASA], Sala Lanciani, Roma XI.58.1.69); 1758, 1, and 1758, 2 (Bern, Abegg Stiftung; see n. 312 below); 1760, 1, and 1760, 2 (New York, Pierpont Morgan Library, 1962.7, and 1962.8; see J. Bean and F. Stampfle, Drawings from New York Collections III: The Eighteenth Century in Italy [New York 1971] 77); 1761, 2 (London, Victoria and Albert Museum, Department of Prints and Drawings, DT.49); 1764, 2 (London, Victoria and Albert Museum, Department of Prints and Drawings, R WS.1 [R]); 1782, 1 (BINASA, Sala Lanciani, Roma XI.58.1.68). For drawings by Palazzi, see Gori Sassoli, 164-69.

${ }^{312}$ This drawing and its companion were once in the collection of H. M. Calman in London; they were sold in 1963 to Mr. and Mrs. Werner Abegg by the M. Knoedler Gallery in New York. Melissa De Medeiros kindly supplied me with sale information and photographs of the drawings.

${ }^{313}$ See the document transcribed in n. 43 above. 


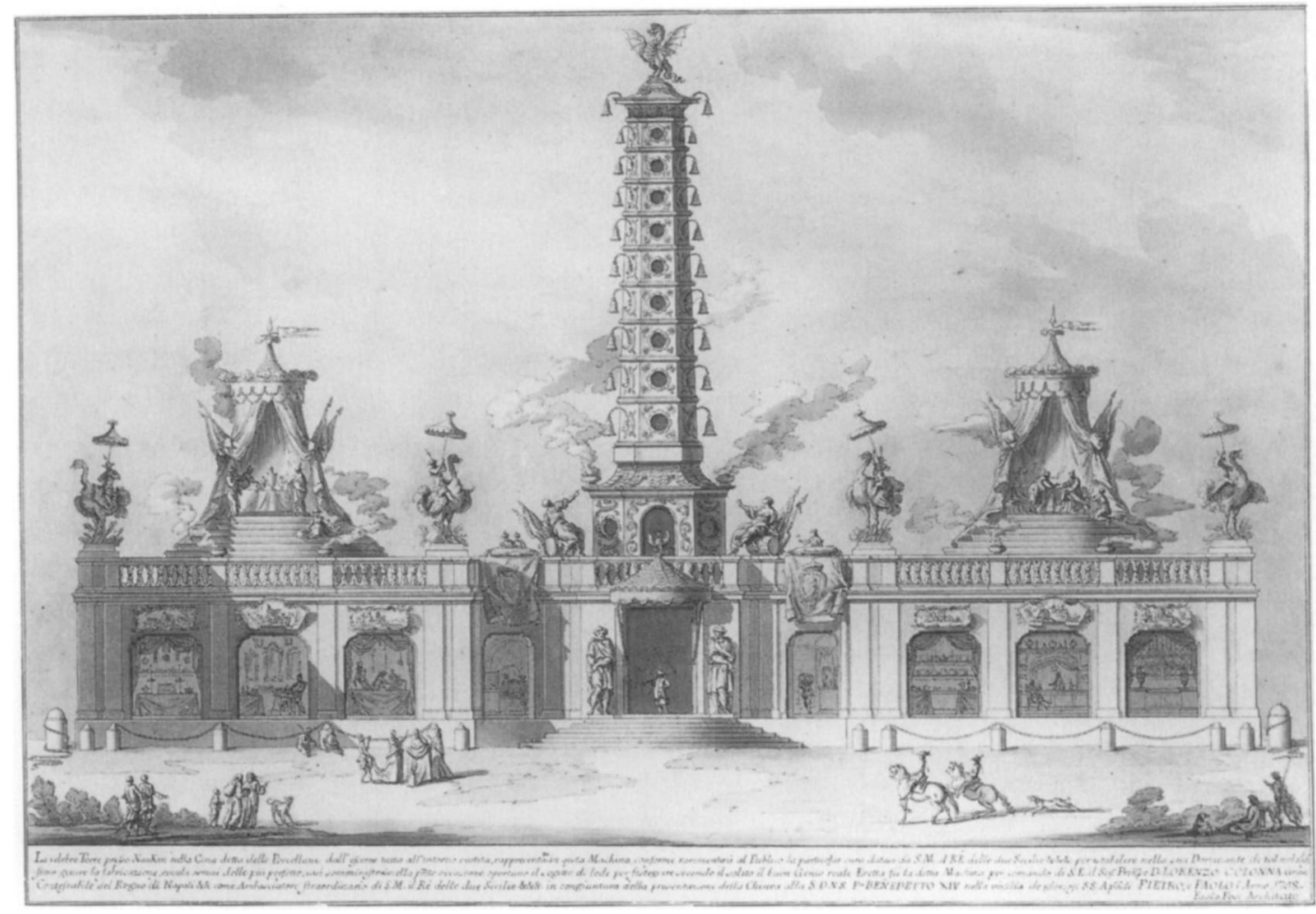

Fig. 30. Paolo Posi, presentation drawing for the second (originally first) set piece for the Chinea of 1758, pen, ink, and wash. Bern, Abegg Stiftung (photo courtesy of Knoedler Gallery).

(figs. 31,32). Thus it appears that the visual shock of the new was properly postponed until the second evening, whereas the specific reference in the draft inscription of the "second" (in fact, first) set piece to "a pleasure pavilion [deliziosa] that His Majesty owns on the Palatine" is thoroughly removed. Grosley, who took his direct observation of the Chinea structures of 1758 as typical of all essays in the genre, observed that "the second structure is always the more spectacular, and none resembles the structures of previous years." ${ }^{314}$ Indeed, a reversal of Posi's projected sequence also occurred in 1761; a preparatory (or presentation) drawing for the second set piece (fig. 22) was originally put forth as the subject of the first. ${ }^{315}$

In 1759 it cost $1,385.70$ scudi to provide cash payments for two drawings produced by a house architect, to reimburse him for expenses, to engage the services of a sculptor, two painters, two masons, and a carpenter, and to reimburse the sculptor for the extraordinary work of the painters after the rain. That sum represents 22.8 percent of the $6,075.475$ scudi spent on the Chinea of $1759 .{ }^{316}$ The carpenter earned the most, probably because he performed so many tasks. On 12 May 1760, Posi himself signed a contract, something that had not occurred before (Appendix, doc. 7). He "offered to take upon himself" all the work that had formerly been contracted to others. He was expressly relieved of any responsibility for the work of the fireworks team. The wording of the contract ascribes to Posi the desire to effect

${ }^{314}$ Grosley, 3:54.

${ }^{315}$ For the location of this drawing, see n. 311 above.
${ }^{316}$ Running total itemized and carried forward in AC, I.B.49, fol. 873, left and right; fol. 885, left and right; fol. 917 , left and right; fol. 954 , right. 


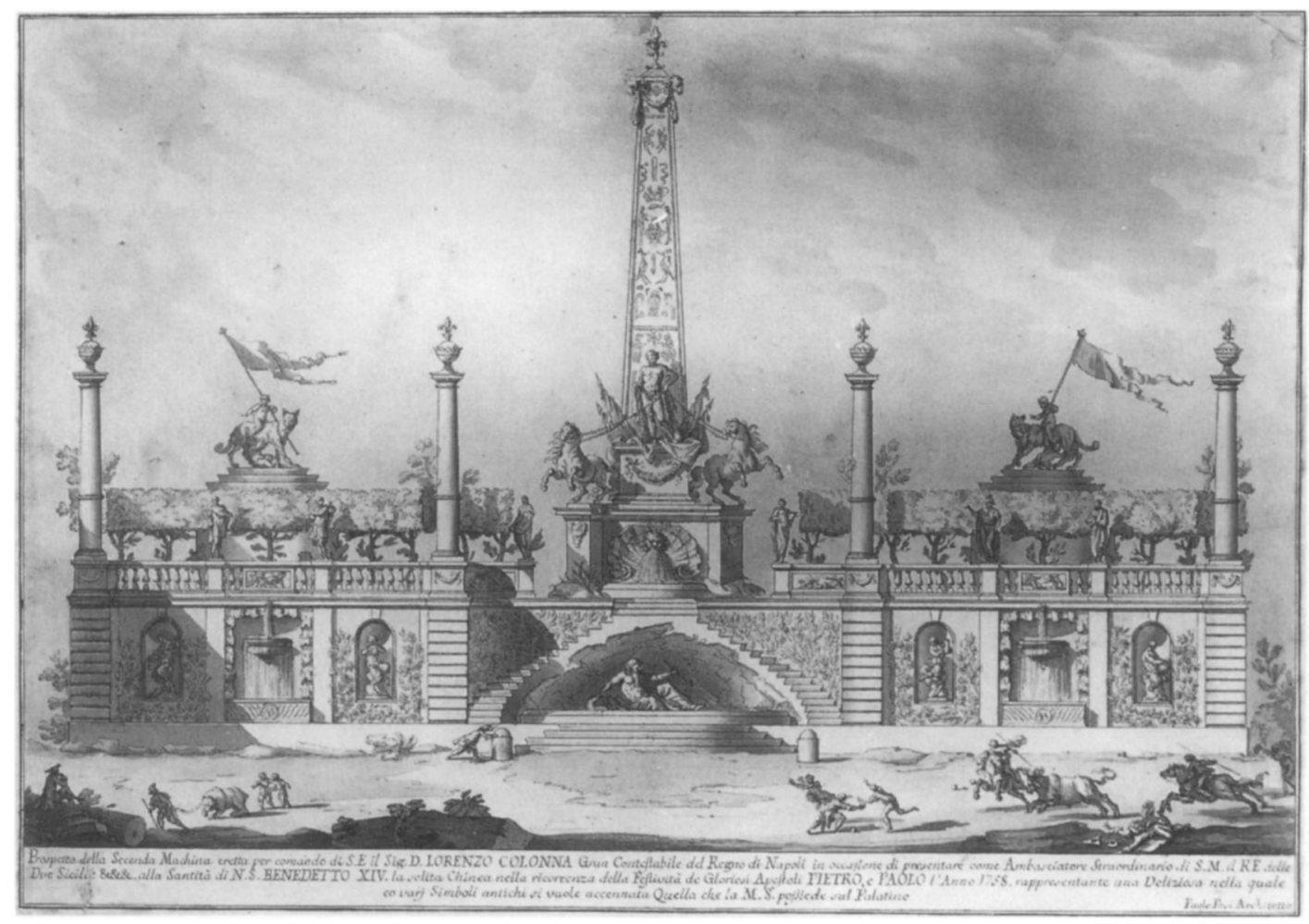

Fig. 31. Posi, presentation drawing for the first (originally second) set piece for the Chinea of 1758, pen, ink, and wash. Bern, Abegg Stiftung (photo courtesy of Knoedler Gallery).

change; the noble constable, located far above the hubbub of quotidian activity, "deigned to accept the said offer." Other archival documents of 1760 suggest instead that the implementation of cost-cutting schemes was motivated by a dramatic change in policy. ${ }^{317}$ Recall the letters written in late 1759 by the new Neapolitan plenipotentiary Orsini, who complained about the sorry state of the Farnese palace and that the constable had expropriated space in the building and satellite structures to save the cost of rental. The changing of the guard brought with it a change in the constable's ability to maintain long-established patterns of

${ }^{317} \mathrm{Cf}$. this financial agreement: "Essendo che dall'Eccmo Sig. Gran Contestabile D. Lorenzo Colonna Prone siasi ordinata la rivisione generale di tutti li Conti di Mercanzie date dalli Sig.ri Giuseppe, e Filippo Bartoli Mercanti in servizio dell'Eccma Casa dal giorno, che principiorno à servirla sino, e per tutto il di 31 Dicembre 17 cinquantanove=per vedere se le tare de medemi Conti sono state fatte à prezzi giusti, e correnti, ed essendosi il Sig.re Giuseppe Bartoli sud.o, non meno per evitare una si longa, e laboriosa fatiga, ma ancora per scansare qualunque difficoltà, e dubbiezza, che potesse incontrarsi nell'Esame di tutte le partite de medemi Conti, esibito di fare un Rilascio sopra tutto il suo Credito, à tutto Dicembre sud.o, siasi questo concordato nella Somma di Scudi Trecentocinquanta= mta"; AC, I.A.445/2. On a 1760 bill for 830 paper lan- terns, the notation "N.o 1900-1759" suggests that the 56.32 percent diminution in number and cost was sought after; AC, I.A.452/327, no. 12. In 1760 , only 4,000 etchings on paper were pulled (see AC, I.A.458/ 133), representing a 43.53 percent diminution over the 7,084 pulled in 1759 , for which see Moore, 595, n. 46. The standard 28 barrels of wine for the fountains in the piazza Farnese were reduced to 27 in 1762, and then to 26 in 1763 ; see, respectively, AC, I.A.461/124, and AC, I.A.466/126. Cf. the following: “@30 Giug.o 1765 / Pietro della Bitta Canavaro hà dato per la scorsa Chinea vino per le Fontane Vino bianco venuto dà Marino Bar. quattordici Vino rosso preso à Ripa Bar. Dodici Meno degli altri anni B. 2 [signed] A. Orlandi M.o C.a"; AC, I.A.475/105. In 1766, 24 barrels were disbursed; see AC, I.A.478/123. 


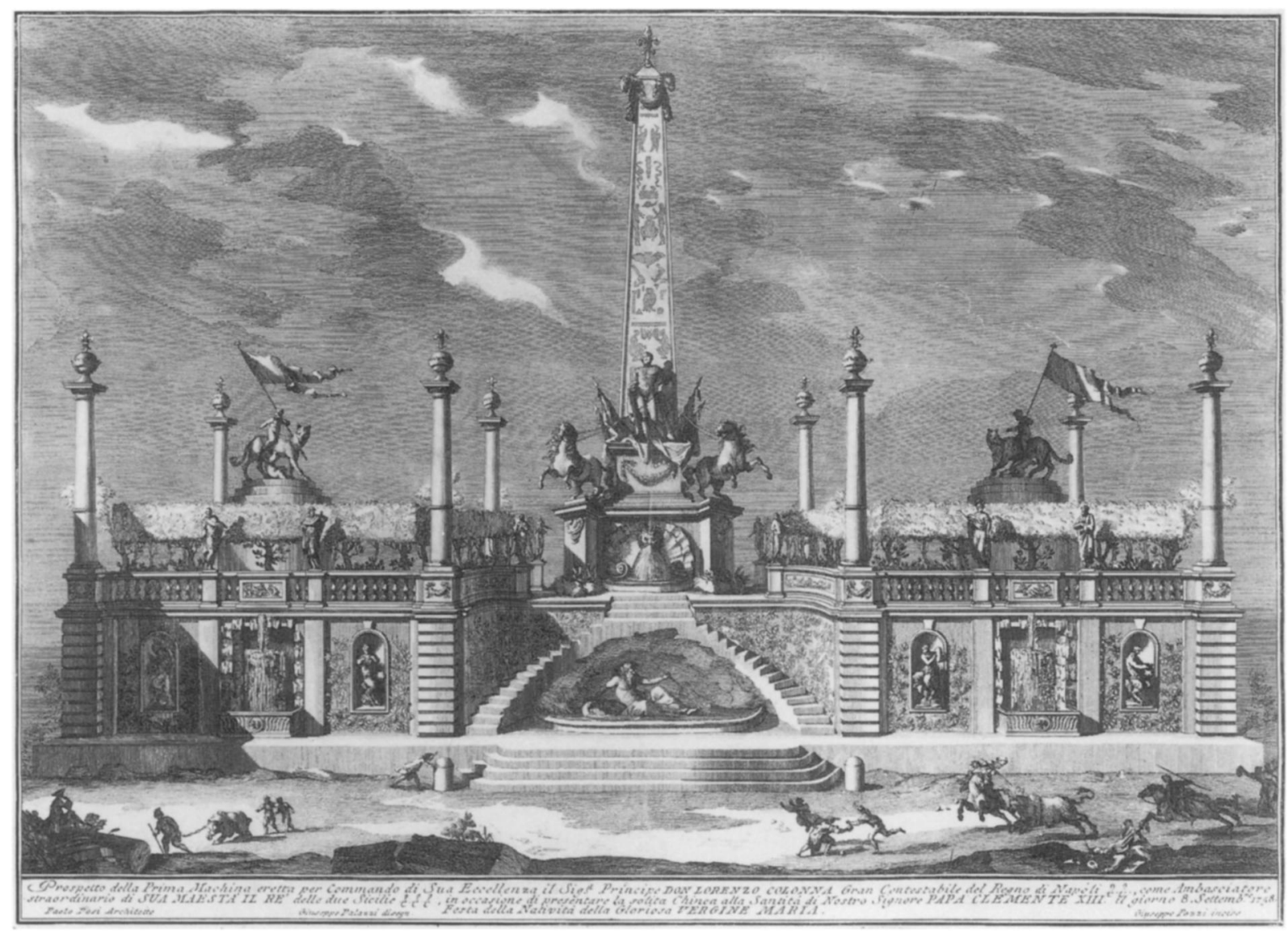

Fig. 32. Pozzi (after Palazzi), first set piece for the Chinea of 1758, etching. Getty Research Institute (photo Getty Research Institute, Research Library).

patronage. To complicate matters further, Lorenzo Colonna, according to Luigi Vanvitelli, was miserly. ${ }^{318}$ Posi had to adapt to a situation imposed from above and to perform tasks he formerly had not.

Posi's 1760 contract continues with a statement that equates it to any legal document drawn up and signed in the Papal States. It is an amalgam of the clauses, requirements, and provisos of earlier artisans' contracts. That Posi presented drawings of his projects to the constable is here stated explicitly: after the constable had approved them, they were to serve as the basis for execution, their details carried out "without any diminution whatsoever, but rather augmented." Posi bore the costs for everything; there is no clause that specifies that he was to receive bails from the constable, although he did. By "everything" the contracting parties intended the work of "mason, carpenter, painter, sculptor, paperer; and work of metal bails, smith, tinsmith, ropemaker, festival-hanger; price of nails, tacks, cord, pins, and all else

318 "Fra quelli che s'impegnano alle feste [for Maria Carolina, promised bride of Ferdinand IV], non sento nominare l'avaro Contestabile Colonna, che meglio degl'altri potrebbe e dovrebbe nella sua galleria darle festa alla Regina di Napoli, anzi l'unico alla di lei contemplazione deve darla per obligo"; Strazzullo, 2:449 (letter from Naples dated 8 Sept. 1767). 
that concerns the selfsame set piece." ${ }^{19}$ Posi was even required to pay for the costs of transporting and storing leftover building materials "just as they [were] found," a proviso that ominously implies that Posi, finding rotten or otherwise ruined materials, would nonetheless have to replace them at cost. ${ }^{320}$

Specific items from earlier contracts are recalled in 1760 . The carpenter had agreed to build various platforms and viewing stands; the architect was now to do the same. He had to use gesso and avoid lime in any painted decoration; to "refresh" the fountains of wine; to provide for gilding and silvering; to supply "plaques, tallow candles-both moldmade and ordinary-for the illumination of the above-mentioned two set pieces." A new stipulation refers to a platform "for the convenience of the musicians who must play the symphonies on the two evenings of the function," although its location is not provided. Posi procured tapestries and other transformative decorative elements and absorbed costs involved in indemnifying suppliers against damages, "which on account of rain, and on account of whatever other motive, might occur." The mention of rain cannot be separated from the events of 1759 . He provided links "that will be necessary to make the set pieces functional and to dismantle them," phrases that respectively evoke strolling onlookers' curious gazes and frantic, all-night work shifts. Posi had to pay for guards employed "to avoid whatever damage and theft might occur between the confusion, and press of the People, which customarily happens after the explosion of the fireworks."

Such centralization of effort is unusual. In 1761 the Roman newspaper includes an account of ephemera built in S. Giacomo degli Spagnuoli, part of the obsequies held for the queen of Spain, Maria Amalia. "Monsignor Giuseppe Herreros," so the account states, "gave the task of such a magnificent funeral to the virtuoso Sig. Giuseppe Pannini, celebrated Roman architect." Also named are four sculptors, the painter-gilder, and the festival-hanger who worked on the cenotaph. The multiplicity of names was an index of the project's importance, for readers in and far from Rome would have been impressed by the insistence on individuals (one of whom was Spanish) whose collective efforts rendered honor to the memory of the deceased. ${ }^{321}$ In the context of the Chinea, however, the new diplomat residing in the Farnese palace and the constable's desire to consolidate expenses combined to alter established practice and to shift many burdens onto Posi's shoulders. By delegating so much to his house architect in 1760 , the constable saved 11.1 percent over the 1759 cost of having the set pieces built and decorated; those initial savings were worth the effort and heralded a new pattern, with further savings coming in 1762 and $1763 .{ }^{322}$ Whatever the changes of 1760 were to bring about, studying the Chinea set pieces of 1759 materially increases our understanding of the building trades and allied industries in eighteenth-century Rome.

\footnotetext{
${ }^{319}$ A clause in Posi's contract of 1761 increased his responsibilities with regard to tinsmith's work: "e queste [macchine] farle fare à tutte e singole sue Spese di robba, e fattura per quello porterà, e richiederà il lavoro di . . . Stagnaro non solo per la conduttura delle Acque da portarsi in dette Machine, mà ancora per tutt'altro, che potrà occorrere in servizio delle medesime"; AC, I.A.453/ 9.

${ }^{320}$ For provisions taken to preserve stored materials intact, see nn. 109 and 142 above.
}

${ }^{321}$ Chracas, no. 6798, 31 Jan. 1761, passim: "avendo . . operato come Scultori il Sig. D. Pietro Rudriez Spagnuolo . . . il Signor Gaspare Sibilla Romano, ed il Sig. Gio: Le Dus Romano ... . il Sig. Tommaso Righi Romano, e Accademico ... come pittore, e doratore il Sig. Giacomo Marini Romano, e come festarolo il Sig. Carlo Calidi."

${ }^{322}$ In 1760 and 1761, Posi received 1,240 scudi for organizing the Chinea; see, respectively, AC, I.A.445/17, and AC, I.A.453/9. In 1762 Posi received 1,100 scudi, in 1763, 1,000; see, respectively, AC, I.A.459/6, and AC, I.A.465/13. 


\section{Conclusions}

Up to this point, I have described the process by which the set pieces of 1759 took form. Accounting records have permitted us to isolate and visualize many material qualities of the structures that could never be discerned or inferred from the observation of details in monochromatic prints or, for that matter, colored presentation drawings. The acts of construction, decoration, and dismantling have likewise been located within the context of long-established economic relationships between the Colonna and numerous artisans, artisans who worked within a distinct and important genre of artistic production that gave regular, ceremonial, and spectacular expression to the visual culture of eighteenth-century Rome.

Establishing the bottom line motivates all bookkeeping. As we already know, the Colonna administration tallied a total of 6,075.475 scudi for the Chinea. One could isolate a subset of payments to "artists," although that raises the question of what constituted an artist. Both firework masters, who worked in the same field as military architects, and festival-hangers should be included in such a grouping. ${ }^{323}$ What the firework masters accomplished gave everyone who cared to watch a visual delight that, one must admit, few paintings or sculptures could match. That fireworks displays cut cleanly across class boundaries and social hierarchies to awaken a sense of wonder is reason enough to take them seriously. They were enjoyed and evaluated in terms of the familiar categories of balance and symmetry. The firework masters' work was an object of considerable aesthetic appreciation and, as such, should engage the historian of art. The festival-hangers, as we have seen, dramatically transformed the interior of the Farnese palace, helped decorate the set pieces, and put lighting fixtures in place.

The architect, sculptor, painters, masons, carpenter, firework masters, and festivalhangers collectively earned $1,883.20$ scudi, or 31 percent of total expenses. ${ }^{324}$ One should probably include the ten silver trays "for pages from outside the family" made by the silversmith Vincenzo Belli, not forgetting the porter who carried the finished products to the Farnese palace; including both individuals' work raises the artists' total to 2,028.35 scudi, or 33.4 percent. ${ }^{325}$ Those involved in making the prints (figs. 1, 2) -the etcher Giuseppe Vasi, the engraver of inscriptions, Giovanni Petroschi, a boilermaker, a papermaker, a mercer, and a box maker, among others-ought also to be included. ${ }^{326}$ Two merchants supplied sources of illumination in the amount of 492.47 scudi, or 8.11 percent of total expenses.

What could one buy with the money spent on the Chinea? However bizarre the comparisons

\begin{abstract}
${ }^{323}$ Monsieur Belland was firework master to Charles II; he prepared grenades for the Office of Ordnance, and "fireworks for ... royal parties and fetes"; P. B. Ellis, The Great Fire of London: An Illustrated Account (London 1976) 98.
\end{abstract}

${ }^{324}$ Total payment for festival-hangers is recorded as 43.40 scudi in AC, I.B.49, fol. 885 right; for an additional payment, see n. 273 above.

${ }^{325}$ AC, I.B.49, fol 885 left: "E adi $30=$ detto [scudi] 144:85 $\mathrm{mta}$ in cro à Vincenzo Belli Argentiere per il prezzo, e fattura di n:o 10=Guantiere d'Argento di Carlino di peso L:e 9:09:12 servite per li Paggi forastieri." "Per porto delle Guantiere alli Paggi [baiocchi] .30"; AC, I.A.443/ 152.

${ }^{326}$ For the Chinea prints of 1759 , see Moore. Since that article was published, I have discovered two other relevant items: "E a di detto [17 Aug.] [scudi] 8:70 mta in cro al Sag: Monte di Pietà pagati à Giuseppe Gamorra Mercante per il prezzo d'Onc: 4:20 Merlettino d'Oro à pizzi con Lama dato in Giugno pas:to per guarnire le Stampe in Seta delle Macchine de Fuochi Arteficiali"; 
drawn may seem, the exercise does allow for a reconstruction of relative values. An annual income of approximately 7,000 scudi from benefices in the Veneto was, in the eyes of the Genoese agent in Rome, a handsome sum for Carlo Rezzonico, nephew of the newly elected Clement XIII. ${ }^{327}$ The cost of the 1759 Chinea would have enabled the Del Cinque family to begin construction of a seven-story palace and apartment block in the piazza Montecitorio in 1738 and to purchase, in the summer of 1740 , an additional plot of land on which three shops had stood. By the end of construction in late 1742, however, total costs had risen to 10,000 scudi. ${ }^{328}$ In October 1761, the Italian Congregation of Discalced Carmelites spent 18,000 scudi to buy the Palazzo Rocci. ${ }^{329} \mathrm{~A}$ fresco of Jupiter and Ganymede, wrongly believed by Winckelmann to be antique, was of a far smaller scale than a palace or a festival, but cost 4,000 scudi. ${ }^{330}$

The resources mobilized to bring about the Chinea invite comparisons with projects sponsored by the papacy. For example, the total expenses for the 1759 Chinea were just 34.6 percent of the sum that Clement XII had originally set aside for the construction of the Trevi Fountain, the increased final cost of which reduced the ratio to 25.4 percent. ${ }^{331}$ The Chinea sum would have generously funded more modest urban interventions, for example, 14.04 campaigns of setting paving stones in front of the church of S. Maria de' Miracoli. ${ }^{332}$ The amount was 3.04 times greater than the monies apportioned to restore the Arch of Constantine. ${ }^{333}$ It would have surpassed by more than tenfold the amount sent to the bishop of Geneva "for subvention to the apostates who returned to the womb of the Holy Church." 334

What papal public-works projects and the privately financed Chinea had in common was a need for many hands. In a city where architecture was the biggest industry, the building

AC, I.B.49, fol. 885 left (cf. Moore, 600); "E a 17=detto [Dec. scudi] 8:65 mta in cro à Giacomo Chellucci Mercante per il prezzo di pmi 7 1/2 Taffetà cremisi, ed Onc: 5:08 Fettuccina d'oro data per guarnire le tre Cassettine per porvi dentro le Stampe delle Macchine de Fuochi mandate fuori"; ibid.

${ }^{327}$ Genoa, Archivio di Stato, Archivio Segreto, Lettere Ministri 2397 (letter from Rome of Casale dated 12 Aug. 1758): "Ha Sua Santità distribuiti tutti i Benefizj vacati nel Veneziano sugl'ultimi anni del suo Antecessore; e nella collazione de medesimi hà contradistinto Monsig.r Rezzonico suo Nipote, cui ne hà conferiti per l'annua rendita di sette mila scudi in circa."

${ }^{328}$ See M. Bevilacqua, "Un palazzo-condominio nella Roma di Benedetto XIV: Palazzo Del Cinque a Montecitorio," in Ville e palazzi illusione scenica e miti archeologici, ed. E. Debenedetti (Rome 1987) 99-113.

${ }^{329}$ Chracas, no. 6909 (17 Oct. 1761) 6-7: "Li RR. Padri Carmelitani scalzi della Congregazione d'Italia, anno comprato il Palazzo Rocci, appartenente all'Eccma Signora Duchessa di Rignano, posto in vicinanza della Chiesa di Monserrato, con una Casa annessa, per il prezzo di scudi dieciotto mila, per ristabilirvi il Convento destinato per li loro Superiori Generali, ed una congrua Communità che prima avevano presso il Sagro Monte di Pietà di Roma, e propriamente in quella piazza, la cui Chiesa era sotto il titolo di SS. Teresa, e Gio: della Croce."

${ }^{330}$ See T. Pelzel, "Winckelmann, Mengs and Casanova: A Reappraisal of a Famous Eighteenth-Century Forgery," Art Bulletin 54 (1972) 304; and S. Röttgen, "Storia di un falso: Il Ganimede di Mengs," Arte illustrata 6 (1973) 256-70.

${ }^{331}$ As of 15 Dec. 1732, the balance remaining after nine extractions of the lotto (and their attendant expenses) was $517,587.12$ scudi. From that sum came this disbursement: "A Monsig. Passarini per l'ornato della Fontana di Trevi [estrazione] 3 [scudi] 17547.715"; Utile, v. The "Ristretto delle Spese occorse ... per la Fontana dell'Acqua Vergine detta di Trevi" cites a total cost of $23,877.72$ scudi; transcription as in Pinto 1986, 277-78.

332 Utile, vii: “Alla Madonna SSma de'Miracoli per la nuova Selciata avanti quella Chiesa [estrazione] 6 [scudi] 432.80."

${ }^{333}$ Utile, v: "Al Signor Marchese Capponi per riattamento dell'Arco di Costantino [estrazione] 5 [scudi] 2000.”

${ }^{334}$ Utile, i: "A Monsig. Arcivescovo di Genevra per sovvenimento a gl'Apostati, che ritornano al Grembo di S. Chiesa [estrazione] 1 [scudi] 600." 
trades kept some away from the mischief that idleness breeds; such was an important consideration for a state that had little industry. ${ }^{335}$ In the foregoing pages, I have often referred to in-kind payments of wine and bread, but one must also imagine drinking the wine and eating the bread. Individuals who sat or stood around the barrel or waited at the dispensing storeoom embodied another facet of human labor, namely, the teamwork that guaranteed the success of ambitious social events. The teamwork was reflected in friendships and familiarities that developed among people who also knew one other because of circumstances of birth, upbringing, or even residence in the same parish. The jugs of wine were meant to be shared, the loaves of bread broken with companions. Workers who took such portions home could make an addition to the food supplies of their poor families, for whom bread was the proverbial staff of life.

\section{REACTIONS TO THE CHINEA OF 1759}

What remain to be delineated are contemporaneous reactions to the finished products whose genesis and construction have already been described. The four principal sources are: (1) a letter from Lorenzo Colonna to Tanucci; (2) Tanucci's response; (3) a printed pamphlet description; and (4) a newspaper report.

In the exchange between Colonna and Tanucci, there is no mention of the set pieces, even though the etchings related to them had been sent to Naples one week before the presentation (figs. 1, 2). ${ }^{336}$ Instead, their communication speaks to the diplomatic and political aspects of the presentation. On 29 June the constable writes that "the present day does not leave [him] the convenience to write out a detailed account of the extraordinary embassy" (Appendix, doc. 8). He refers to the busy Tanucci, whom "more serious matters would not permit" to read anything longer "without tedium." He speaks of the embassy as an honor with which it pleased the king to invest him. Colonna stresses three points: that "the function succeeded in every one of its parts with the usual propriety, decorum, and magnificence"; that the "viewing public," both during the procession and at the fireworks displays, "was innumerable"; and that "there was no person of rank, whether ecclesiastical or secular, who did not come personally, or by means of his gentlemen," to participate in the cavalcade, or to the receptions in the Farnese palace.

What the constable expresses touches on well-established leitmotifs. The adjective "usual" (solito) appears, indicating how the history of the event served as a paradigm for subsequent incarnations. Change-the unusual, the unexpected-signified a lack of control and was thus anathema to ambassadors and their sovereigns. The triad of "propriety, decorum, and magnificence" characterizes an event whose components formed an orchestrated, meaningful whole. That rain nearly obliterated the magnificence did not alter the outcome. The constable's letter purports to describe the finished product, not the process that created it.

The "viewing public," anonymous and infinite, enjoyed a considerable collective strength. For the constable's embassy to succeed as it moved toward the Vatican, the processional route had to be tightly lined with onlookers. The masses in the street were distinguished from the

${ }^{335}$ For the importance of architecture in the economy of Rome, see C. Paola Scavizzi, "Le condizioni per lo sviluppo dell'attività edilizia a Roma nel sec. XVII: La legislazione," Studi romani 17 (1969) 160-71, and id.,
"Considerazioni sull'attività edilizia a Roma nella prima metà del seicento," Studi storici 9 (1968) 171-92.

${ }^{336}$ For the dispatch of prints, see Moore, 601-3. 
invited guests who, the constable writes, attended without fail and thus "demonstrate[d] their veneration and attachment to such a king." To be absent would have constituted an affront, calling abruptly into question hierarchies of privilege and position. With lists recording the guests' names sent to Naples, the king could learn how his subjects and those who owed him other loyalties comported themselves in his absence. Servants of the invited and others involved in the receptions were required to work on this half bank holiday. ${ }^{377}$ In contrast, the nameless populace in Rome was neither invited nor required to participate. Although both Colonna and king needed their presence, neither could say as much. Thus the annual event expressed dependence in terms of a generous, spectacular display that engaged the senses and addressed the intellect. ${ }^{338}$

Having heard from Colonna "attestations of the royal, signal piety, and highest devotion toward the Holy See and toward the sacred person of His Holiness," the pope "was moved." "With expressions corresponding to his approval, and his most sincere paternal affection," he "gave an apostolic blessing to His Majesty and to the entire royal family." In the end, benediction was all the pope had to give. He said nothing about the king's power, wealth, or subjects. Instead, he prayed for the monarch's health "and for the happiness of many offspring."

The constable ends his letter by asking Tanucci "to bring to His Majesty in a humble fashion" his account, which represents the discharge of his "duty." He hopes that the monarch will look with patience upon the ambassador's weaknesses in carrying out his charge and closes "with the usual inviolable deference." He left out some words of others who witnessed his embassy. The Vatican diarist's account of 1759 states that the pope, "borne in his gestatorial chair, accepted the tribute at the door of the basilica." Then the Neapolitan-born treasurer "made a protestation in favor of the direct dominion of the Apostolic See over the Kingdom of the Two Sicilies." ${ }^{339}$ The constable heard this protest, since the diary states that he left afterward. If it was delivered in Latin, he still understood it, for he had received enough education to understand simple bureaucratic Latin, just as he could understand the mass. Perhaps the treasurer referred to the duchies of Parma and Piacenza as well, over which the pope claimed sovereignty, but which since the 1748 Treaty of Aix-la-Chapelle had been given to Spain. A protest was read after vespers on 28 June every year, even though there was little hope of resolution in the pope's favor. ${ }^{340}$

Tanucci's response dates to 3 July (Appendix, doc. 9). He writes that the king already knew from experience the extent of the constable's "zeal, fervid application, and attachment to [the] royal service." Thus "it hardly came as something new" that Colonna had successfully discharged his extraordinary embassy to present the Chinea. The king "heard with satisfaction" that the function had had a "joyous and tranquil outcome." It pleased him to learn

${ }^{337}$ Notizie per l'anno 1759 (Rome 1759) 7: "Vacanze solite farsi nelli Banchi del Sagro Monte della Pietà, di San Spirito, ed altri . . . Il dopo pranzo della Vigilia di S. Pietro Apostolo, benchè non si presenti la Chinea, e venendo la Festa di Lunedi vaca il Sabato."

${ }^{338}$ S. de Beauvoir, Le deuxième sexe (Paris 1976) 17: “entre villages, clans, nations, classes, il y a des guerres, des potlachs, des marchés, des traités, des luttes qui ôtent à l'idée de l'Autre son sens absolu et en découvrent la relativité; bon gré, mal gré, individus et groupes sont bien obligés de reconnaître la réciprocité de leur rapport."
${ }^{339} \mathrm{BAV}$, MS Vat. lat. 8393, fols. 71-72: “Die 28. Iunij Feria 5. D. Comestabilis Columna Orator extraordinarius Caroli I. Regis Neapolis a prandio se contulit ad Vaticanum in vigilia SS. Apostolorum, pervenit illus tempore, quo jam expleti erant Vesperi Papales; Pontifex Gestatoria vectus ad portam Basilicae excepit Tributum pro Regno Siciliae ad enunciato Oratore oblatum. D. Fiscalis protestatus est favore Sedis Apostolicae pro directo Dominio Super Regno utriusque Siciliae; et Orator discessit." For Perrelli, see Notizie (as n. 337) 47.

${ }^{340}$ See Pastor, 35:130 and 36:265. 
that both ecclesiastics and the secular nobility in Rome had participated in what constituted the king's "act of the most exemplary devotion to the Holy See." The king "was moved" to learn of the "paternal papal reception" of the ambassador extraordinary. In closing, Tanucci communicates the king's "full approval," while the writer "takes all the pleasure" in effecting his monarch's orders.

Missing in Tanucci's response is any reference to feudal homage. He speaks of what the constable did generically, as "an extraordinary embassy," which does not necessarily imply that one sovereign's proxy has prostrated himself in front of another sovereign. Tanucci refers to the seat of the pope's power, his role as father of the faithful. The king's "religious spirit" was moved by the constable's account, and appropriately so, because the pope's role as spiritual leader was not contested. Yet casting him exclusively in such terms suppresses his claim to be a temporal ruler.

This exchange of letters insists upon the essential characteristics of ritual, which one historian has identified as "public, stereotyped, and symbolic." 341 The symbolic import of the events described was the least agreed-upon aspect of the whole. Still, this triad of qualities can be used as an interpretative framework for the printed descriptions of the event.

The set pieces of 1759 were a great success. The printed pamphlet description likens the scene represented in the second set piece (fig. 2) to "an embellished [istoriata] disposition of the groups and figures that industrious Saxony transmits to us." ${ }^{342}$ As a young man, Lorenzo Colonna had traveled to Dresden, and just two months after the Chinea of 1759 , he sent a porcelain bowl to his future bride in Milan. ${ }^{343}$ The evocation of "industrious Saxony" recalls the nation in which expensive and coveted luxury objects of eighteenth-century Europe were produced and evokes a typically southern characterization of Germans, just as the adjective "ultramontane" identifies a line of cultural demarcation. Such characterizations have their counterpart in Grosley's observation that "idleness" prevailed in Rome. ${ }^{344}$ In referring to Meissen porcelain, the writer of the printed pamphlet assumes that readers could, on the one hand, make cross-media comparative analyses and, on the other, understand how compositional organization and iconography signaled a national style. Saxony was intimately connected to the presentation of the Chinea, since the elector, Frederick Augustus II, staunch in his Cathoiic faith against his own subjects and many reigning Protestant peers, most notably

${ }^{341}$ P. Burke, The Historical Anthropology of Early Modern Italy. Essays on Perception and Communication (Cambridge 1987) 225 .

${ }^{342}$ Descrizione delle due machine di artifizio erette in Roma nella Piazza Farnese in occasione di presentarsi la Chinea

Nelle due Sere 28., e 29. Giugno dell'Anno 1759. Inventate, e Dirette dal Signor Paolo Posi Architetto (Rome 1759) iii.

${ }^{343}$ Dresden, Sächsisches Hauptstaatsarchiv, Geheimes Kabinett, H.St.A 662, "Depeschen und Briefe des Grafen von Lagnasco aus Rom. 1754-1756" (letter from Rome of Lagnasco dated 1 Nov. 1755): "Dopo una malattì di tre settimane è morto il Contestabile Colonna compianto da tutta Roma per la sua somma integrità di vita, e per l'eccedente sua compitezza con Tutti. Il Papa ha subito scritto al Re di Napoli per fare continuare nel Figlio del Defonto D. Lorenzo Colonna, che ha avuto l'onore di fare la sua Corte a Vostra Maestà in Dresda, la Carica di Contestabile del Regno, passata in nove Generazioni della medesima Casa; Ma non si sa ancora, se potrà ottenerla per conto de' forti Concorrenti, che vi saranno, fra quali ne sarà un ben potente il Cardinale Orsini, che si trova attualmente in Napoli, e vorrebbe avere detta Carica per il suo Figlio il Duca di Gravina." Marianna d'Este received " $[u] n$ vago tondo con sua tazza di porcellana di Sassonia, con suo cucchiaro d'oro mirabilmente lavorato"; Chracas, no. 6576,1 Sept. $1759,8$.

344 “ [The population of Rome] is kept up, not by the children born there, but by Italians, and people of all nations, flocking thither; of whom not a few settle, on account of the many helps and conveniences the place affords to laziness" ("dont une grande partie profite, pour s'y établir, des ressources qu'y trouve la fainéantise"); quoted trans. in Nugent, 2:175-76; French original in Grosley, 3:150. 
Frederick the Great, was regularly sent impressions of Chinea prints on satin and paper, as were the sovereigns in Madrid and Naples, according to a protocol preserved in the Colonna archive. ${ }^{345}$ Referring to Saxony could also be understood as a flattering acknowledgment of Maria Amalia, queen of the Two Sicilies.

The pamphlet ends its brief descriptive narrative of Posi's work with the claim that "the novelty and the good order with which the described set pieces were executed ... left in everyone the desire to enjoy them for a longer time." But since it was almost certainly written and published before construction and decoration were complete, it is to the newspaper of eighteenth-century Rome to which we must turn to obtain an eyewitness account of the events of 1759 .

The newspaper came out three times a week and reached an audience outside Rome. ${ }^{346}$ Wednesday and Friday numbers were primarily devoted to world events culled from other gazettes, journals, broadsides, similar printed sources, and letters, in a process typical of the publishing industry throughout seventeenth- and eighteenth-century Europe. ${ }^{347}$ The Saturday number was dedicated to Rome and was often twice, if not three times, as long as the others. The pope's movements were described in exhaustive detail as were those of the cardinalate, the high prelature, and, to a lesser degree, the Roman nobility. What Caterina Chracas, editor from 1731 to 1771 , learned of the pope's activities was at least one remove from the source, since women were rarely allowed in his immediate presence, and never without considerable mediation. ${ }^{348}$ Nevertheless, the predictable, protocol-bound nature of his persona made reasonably accurate reporting possible. If Roman news was scanty, remaining pages in a given number were filled with foreign reporting. Summaries of promulgated edicts, exalted visitors' arrivals and departures and accounts of their Roman sojourns, the course of illnesses and recoveries, deaths among the privileged classes, notices of capital punishment, and weather reports numbered among the subjects regularly treated. ${ }^{349}$

${ }^{345}$ See Moore, 600-602.

346 "Chi dunque giudicasse di acquistare l'Opera così accennata [a set of engraved plates of an Etruscan vase], trovi in Roma un qualche Corrispondente, che vada o al Museo Kirker medesimo, o alla Stamperia del detto Gio: Zempel, e pagando paoli dicisette avrà i fogli nove già impressi, al ricevere de'quali pagherà altri paoli trentadue prezzo de'fogli sedici susseguenti, che subito verranno consegnati a chiunque degli Associati riporterà il Biglietto stampato, che ricevè nel prendere l'Associazione"; Chracas, no. 7155, 14 May 1763, 15-16. Ascolese now and then mentions sending the newspaper to his correspondent, which he often did on Tuesdays, ostensibly after having gathered the previous week's numbers; AS, AER 1079, passim. Throughout the year 1769, Spanish auditor Tomás Azpuru regularly finishes his dispatches with the assertion that he is sending "los adjunctos [or 'acustombrados'] Chracas"; AGS, SE 4977, passim.

${ }^{347}$ In 1729 Philipp von Stosch must have passed on a letter from his hometown of Küstrin that described a fire in nearby Fürstenfeld; Chracas, no. 1871, 3 Aug. 1729 (dateline Küstrin, 28 June) 20-21. "L'Imperadore dà
Laxemburgo era passato alla Favorita, qualche lettera dice"; AS, AER 1244 (letter from Rome of Giovanni Porta dated 3 July 1739). Over the years, the Colonna subscribed to newspapers, the Gazette d'Utrecht, and the Courier d'Augsbourg. For a 1765 preprinted French bill of subscription paid at the Rome branch of the Milan post office, see AC, I.A.474/174.

${ }^{348}$ For Caterina Chracas, see V. H. Minor, "References to Artists and Works of Art in Chracas' Diario ordinario, 1760-1785," Storia dell'arte 46 (1982) 217.

${ }^{349}$ A mazarinade of 1649 considers frivolous an emphasis on local affairs, including detailed reporting of fireworks displays: " $\&$ lors que toutes ces matieres Illustres manquent à son sujet, elle reuient à son uillage, \& treuue dans Paris assez de fatras \& d'incidens pour en remplir ses cahiers iusques au goulet, dira qu'vne telle Dame est accouchée d'vne fille, qu'elle a esté baptisée dans telle Eglise, que tels \& tels l'ont tenuë sur les fonds, qu'vn tel a pourueu son fils de la charge de Conseiller, que tel autre a resiné son Abbaye à un tel, qu'il a soustenu vne These en Sorbonne, que l'on a tiré devant le Roy vn feu d'Artifice, \& en expliquera les particularitez, qu'vn tel Seigneur n'est plus malade, \& qu'il se porte bien de sa 
An eighteenth-century Englishwoman thought Rome lacked a proper newspaper, in which one could learn "who is murdered." 350 The newspaper told what some Romans did to pass the time, to mark the course of the year, to connect the present with the past. The cyclical nature of certain events and their accompanying celebrations made historical time immediate, personal, and participatory. ${ }^{351}$ Except for inconsistent references to the designers, there is no discussion of the varied human labor that created the set pieces for the Chinea, for it was not the process of construction but the finished product whose dimensions, decoration, and iconography merited explication.

The set pieces were never subtracted from the overall framework of diplomatic protocol; thus Chracas describes the rich procession that began at the Farnese palace, moved along the via Papalis, and ended in St. Peter's, an urban trajectory lined "not only [with] Romans, but people from surrounding regions, to say nothing of the nobility, who were spectators even in their coaches." Turning to the second set piece "of a completely new conception," she writes that the "virtuoso" architect Posi "drew to himself the applause of all Rome, as he has likewise done on all the occasions that have presented themselves to him to make known his great talent and witty conception [graziosa idea]; in proof of which suffice it to say that to satisfy both the nobility and the people [Plebe], it was thought advisable [è convenuto] to leave the above-mentioned second set piece, reputed to be one of the most beautiful ever seen for similar occasions, intact for a few days." ${ }^{352}$ The invocation of two parts of Roman society usually leaves no doubt as to which was superior. What is different here is that Posi put forward his "witty conception" for the scrutiny of a unified public. He and Chracas assumed that everyone was capable of passing knowledgeable judgment on a work of ephemeral art. In this instance, the opinion and will of nobles and commoners mattered and determined policy.

The second set piece of 1758 , representing "the tower near Nanking in China," was also kept intact for one extra night (fig. 23). The chinoiserie "Salottino di Porcellana" at Portici had been under construction since 1757, so Posi's pagoda fits into an established iconography that identified, for a Roman viewing audience, the architectural, engineering, and archaeological projects and works of public benefaction sponsored by Charles VII, who had,

goutte que l'on a treuué quelque machine nouuelle pour faire des carrosses a peu de frais, que la riviere est fort grosse, \& que le pain est à bon marché. Ne sont-ce pas là des belles nouuelles à mettre dans l'Histoire?"; Le commerce des novvelles restably, ov le covrrier arresté par la gazette (Paris 1649) 8.

${ }^{350}$ [H. L. Piozzi], Observations and Reflections made in the course of a journey through France, Italy, and Germany, vol. 1 (London 1789) 422: "He went however only five doors further, found a sick old gentleman sitting in his lodging attended by a feeble servant, whom he bound, stuck a knife in the master, rifled the apartments, and walked cooly out again at noon-day: nor should we have ever heard of such a trifle, but that it happened just by so; for here are no newspapers to tell who is murdered, and nobody's pity is excited, unless for the malefactor when they hear he is caught."

${ }^{351}$ J. Jacquot, "Présentation," in Les fêtes de la Renaissance, vol. 3, ed. J. Jacquot and E. Konigson (Paris 1975)
11: "La fonction première de la fête est de raviver dans les groupes humains la mémoire de leur passé (historique ou legendaire) et de renforcer la conscience de leur permanence. Mais bien que le poids de la tradition s'y fasse sentir partout, dans le tracé des itinéraires, les détails du cérémonial, la construction des décors, l'emploi des thèmes et des symboles, l'appareil de la fête et ses significations évoluent avec la structure des sociétés et la forme de leur culture." "For, in these 'early' societies, social phenomena are not discrete; each phenomenon contains all the threads of which the social fabric is composed. In these total social phenomena, as we propose to call them, all kinds of institutions find simultaneous expression: religious, legal, moral, and economic. In addition, the phenomena have their aesthetic aspect and they reveal morphological types"; M. Mauss, The Gift. Forms and Functions of Exchange in Archaic Societies, trans. I. Cunnison (New York 1967) 1.

${ }^{352}$ Chracas, no. 6552, 7 July 1759, 13. 
in fact, established a porcelain factory at Capodimonte to challenge the economic hegemony of that famous one in "industrious Saxony." 353 The newspaper recounts that "it was necessary to maintain the set piece until the following Sunday, in order to satisfy the desire and curiosity of the many people who, because of the large crowd, could not enter the square to see the set piece." ${ }^{354}$ On the morning of 9 September 1758, one wonders what rumors flew through the city about this structure, painted in the guise of blue porcelain and outfitted with crazily ringing bells. Chracas wrote that such a prolongation "had never happened before for similar occasions." In the account of 1759 , the vague phrase "it was thought advisable" explains an unusual course of action, but who were the agents of that action, and what criteria did they use to make their decision?

That the people wished to prolong the life of the second set piece suggests that the thrill of drinking free wine and watching dramatic fireworks displays could be temporarily supplanted by the conscious visual enjoyment of a set piece. The events of 1758 and 1759 lend support to the observations of a French consul in Rome, who wrote in 1728 that "the people, the natural judge of everything one gives to the public," were fully competent to evaluate festivals. ${ }^{355}$ As they compared new manifestations with earlier essays in the genre, they displayed a historical memory both potent and critical and were extremely sensitive to the political implications of diplomats' activities. ${ }^{356}$ The events that gave rise to set pieces were bound by time, whether linear or cyclical: a first-born prince was born just once, the Chinea was presented just once a year. A recurrent event might be thought repetitive and unsurprising, but in the words of Ascolese, "all of Rome was in an uproar" over the Chinea of 1759, "applauding the only lavish festival to be seen, even though it is annual." 357 The events were ephemeral, but the public was permanent. That same public, in 1758 and 1759, insisted that the ephemeral be made to last, a proposition that is in some ways analogous to the aim of this essay.

\begin{abstract}
${ }^{353}$ For the subjects of Chinea set pieces, see Gori Sassoli, esp. 23-24; for the porcelain room (now Naples, Capodimonte), see The Dictionary of Art, vol. 5 (London 1996), s.v. "Capodimonte Porcelain Factory." According to a manuscript note in the Colonna archive of unestablished authorship quoted in Gori Sassoli, 63-64, the second set piece of 1758 "will recall to the public the particular care that His Majesty the king of the Two Sicilies took upon himself by establishing within his dominion a [porcelain] factory."
\end{abstract}

${ }^{354}$ Chracas, no. 6426, 16 Sept. $1758,10$.

${ }^{355}$ AN, AE B.I.962 (letter from Rome of Pressiat dated 7 July 1728): "Le Card.I Bentivoglio donna enfin sa feste Dimanche ... . La feste auroit esté aussy complette que Brillante si les effects du feu avoient repondu a la grandeur et la Beauté de la machine, le peuple juge naturel de tout ce qu'on donne au public avoit conçu des idées proportionnées a l'objet qu'on luy presentoit. Voila a quoy on est sujet dans ces sortes de demonstrations, le peuple cependant est plus touché d'un spectacle de cette nature que de tout ce qu'on peut faire, d'ailleurs Rome est un grand theatre ou chaqu'un se donne en spectacle au monde entier et ce n'est que par la profusion et le goust qu'on y ramasse les suffrages des Diverses nations dont le public y est composé."

${ }^{356}$ AN, AE B.I.964 (letter from Rome dated 18 May 1742): "M. de Thun fit elever samedi passé les armes de la Reine d'Hongrie sur la porte de l'Eglise de l'Anima, oú tous les badauts de la ville et notamment les geniaux Autrichiens ont couru en foule comme à une feste; on avoit mesme mis des bancs dans la rüe affin qu'on pust les contempler avec plus de commodité. Le Cardinal Borghese a fait mettre de son costé celles de l'Empereur sur la porte de son Palais comme Comprotecteur des Eglises de l'Empire."

${ }^{357}$ AS, AER 1079 (letter from Rome of Ascolese dated 29 June 1759): “Ieri sera furono fatte le consuete dimostrazioni di giubbilo con la Girandola dal Castel S.t Angelo, e Fuoco d'Artificio nella R. Piazza Farnese, quali questa sera si replicano, e per tale distrazione stà tutta Roma in moto applaudendo l'unica strepitosa Festa, che si veda, quantunque annuale." Fourteen years beforehand, Charles VII reputedly said that the Chinea was "la funcion mas seria, que se hace anualmente en Roma"; AGS, SE 5845, doc. 55 (letter from Portici of the marquis de Salas dated 25 May 1745). 


\section{APPENDIX}

\section{Contract of the sculptor Giovanni Battista Grossi, 7 May 1759 (AC, I.A.436/13)}

Con la presente da valere come publico, e giurato Istromento rogato per mano di qualsivoglia publico Notaro; Io sottosc.to Gio: Batta Grossi mi obligo di fare à tutte mie spese tutti, e singoli lavori che occorreranno per la costruzione, tanto del Primo, che del Secondo Fuoco, che si doveranno fare per la presentazione della prossima Chinea, e specialm.te di cavare dalle Cantine, e Rimessioni in qualunque luogo posti tutti li Fusti de Telari, Busti, e tutt'altro che occorrerà, e quelli trasportare nel luogo de Fuochi, e dove mi verrà ordinato non solo dall'Architetto, ma anche dal Pittore, e Falegname, con porre per tale effetto tutti quelli Uommini che saranno necessarij, e che ordinerà il sud.o Architetto, conforme anche sparato il primo fuoco disfare con tutta diligenza il med.o, e far trasportare la robba del med.o nel sito, ò nè Siti che mi verranno ordinati dall'Architetto, come anche terminato il Secondo, e disfatto riportare la robba sia del Primo, che del Secondo Fuoco nè Luoghi, e Siti de Rimessioni, e Cantinoni che mi verranno dal med.o Architetto indicati con tutta diligenza, ed attenzione, con rilassare tutte le robbe da me date, fatte, e messe in opera, benche qui non espresse, e che meritassero special menzione, obligandomi di rilassare il tutto à favore di $\mathrm{S}$. E. Pne il Sig.re Gran Contestabile D. Lorenzo Colonna per servizio dell'Anni venturi.

In oltre mi obligo di fare à tutte mie spese con Cerchi, e Cerchietti tutto quello che mi verrà ordinato da d.o Architetto cioè coprire con Cerchi li Telari di nuvole, Scogli, ò altro, e di fare tutta quella quantità di figure, Vasi, Gigli, e tutt'altro che occorrerà per le due Machine de sud.i Fuochi à piacere, e contentamento di d.o Architetto, ed in tutto, e per tutto inconf.a delli Disegni fatti dal med.o Architetto, e da me ben visti, e considerati, e quelli lavori compiti che saranno con li Cerchi mi obligo coprirli à tutte mie Spese, con Carta, Colla, ed altro che occorrerà, e di porre alle Figure le Teste, mani, e Piedi, e tutt'altro che occorrerà secondo li detti Disegni, e come mi verra ordinato da d.o Architetto.

Parimente mi obligo d'incartare li sudi. lavori con buona Carta da scrivere e non Carte frolle, e Cartaccie comprate, ma bisognando con Carta doppia acciò possa reggere la Pittura, con buona Colla, ed abbondante senza alcun sparambio, e di fare tutte le legature de Cerchi con filo di ferro nuovo, folte, e dove occorreranno, con porvi ancora tutti li Chiodi necessarij, ed altro à tutte mie proprie Spese

Occorrendo ancora di dovere alzare, sbassare, rivoltare, trasportare Telari, Figure, Ornati per commodo de Pittori, e Falegnami mi obligo di fare à tutte mie spese con Uommini, e Facchini perche così e non altrimenti

In oltre mi obligo di fare à tutte mie spese le Teste, mani, e Piedi, conforme ancora ogn'altro ornato di Carta pista che mi sarà ordinato dal sud.o Architetto, senza che S. Eccza sia tenuto à soggiacere ad alcuna spesa di Forme, Modelli, Colla, legni da ordine, filo di ferro, ed altro che sarà di bisogno, non solo per li sudetti lavori di Carta pista, ma di ogn'altro di sopra descritto, e che puol cadere nella presente obligazione.

Mi obligo in oltre di portare e riportare quante volte sarà di bisogno, e mi verrà ordinato dall'Architetto, Pittore, Falegname, e Architetto li lavori perfezionati alla Piazza del Fuoco, e di porli ove mi sarà ordinato per conservarli per la Seconda Machina, e di accostarli alli Ponti 
de Muratori con tutti quelli Uommini che saranno necessarij da ritenersi à mie spese sotto l'obedienza de sudetti perche cosi e non altrim.ti

Per tutti, poi, e singoli di sopra descritti lavori niuno eccettuato, e di ogn'altro anche nel presente obligo non espresso, purche non sia di sfera di Pittore, Falegname, Muratore, mi obligo di porre tutta quella quantità di Uommini, che sarà necessario, con porre alli med.i Soprastanti, Capocci, ed idonei per evitare ogni disordine, e confusione, ed acciò li sud.i lavori siano fatti, e perfezionati con tutta l'attenzione, e fedeltà nel modo, e forma che mi sono obligato, e contravertendo Io à qualsivoglia di sopra descritto mi obligo, e à qualsivoglia ordinazione che mi sarà data, voglio che in tal caso sia in arbitrio di S. Eccza, ò dell'Architetto di far compire l'ordinazione ò il lavoro da altri à tutti miei danni Spese, ed interessi perche cosi e non altrimenti

Tutti, e singoli li sudetti lavori Io Infrascritto come sopra, mi obligo farli per la Somma così convenuta, e concordata di Scudi Trecento=mta con che S. Eccza sia obligato di darmi tutta quella quantità di Cerchi, e Cerchietti, che ritrovasi avere presentemente nel suo Palazzo, e Cantine, e mancando qualche porzione di Cerchietti sia obligata l'Eccza Sua somministrarmela ${ }^{358}$ senza alcun pagamento, ed in oltre debba consegnarmi Barili Quattro $=$ Vino per il rifresco di tutti quelli Uommini che da mè Infrascritto saranno posti per eseguire gli ordini che mi saranno dati.

E per osservanza di tutte, e singole cose esprese di sopra Io Infrascritto mi obligo nella più ampla forma della Rda Camm.ra Apostolica con tutte le solite Clausole promettendo In fede qsto di 7: Maggio 1759

Io Gio: Batta Grossi mi obbligo come Sopra mpa

Luigi dè Sanctis fui pnte Testimonio alla Soprasctta Sottoscriz.e m.o pp.a

Andrea Dotti fui pnte Testimonio à qnto sopra m.o pp.a

Io Gaetano Rusca fui pnte à qnto Sopra m.o pp.a

2. Contract of the masons Alessandro Bernascone and Giovanni Giobbe, 7 May 1759 (AC, I.A.436/15)

Colla presente da valere come publico, e giurato Istro rogato per mano di qualsivoglia publico Notaro, Noi sottoscritti Muratori qui presenti ci oblighiamo di fare tutto il Castello di Legname, ed altro, che occorrerà per le Machine del Primo, e Secondo Fuoco, che S. Eccza il Sig.re Gran Contestabile D. Lorenzo Colonna Prone fà fare per le due Sere della prossima funzione della Chinea, secondo il Disegno, ed ordinazione, che ci verrà fatto dall'Architetto dell'Eccza Sua tutto detto lavoro ci oblighiamo, e promettiamo di farlo ad uso d'arte, ed à tutta Nra Robba, Spesa, e fattura, ed à contentamento del sud.o Architetto, e ci oblighiamo di fare tutto il sud.o lavoro per il prezzo, e nome di prezzo in tutto di Scudi Duecentocinquanta=mta da pagarcisi di mano, in mano, che anderemo facendo il sud.o lavoro quali promettiamo, e ci oblighiamo di farlo ad uso di buon arte, e per il tempo, che dal sud.o Architetto ci verrà prescritto, e mancando di farlo possa, e sia lecito all'Eccza Sua di farlo fare à tutte Nostre

${ }^{358}$ Only la was written at first; the pronoun $m e$ was added to the infinitive. 
Spese, danni, ed interessi, e per osservanza di tutte, e singole cose di sopra descritte oblighiamo Noi stessi, Beni, ed Eredi nella più Ampla forma della Rev: Cam.ra Aplica, con tutte le solite Clausole, rinunciando, acconsentendo unica, in fede di che abbiamo sottoscritto la presente di Nostra propria mano alla presenza dell'Infrascritti Testimonij, questo di 7 Maggio 1759

[signed] Allesandro bernascone

[signed] Giovani Giobbe

\section{Contract of the carpenter Giuseppe Alberici, 8 May 1759 (AC, I.A.436/16)}

Con la pnte da valere come publico, e giurato Istro rog.to per mano di qualsivoglia publico Notaro, Io Sottos.ro Falegname qui presente mi obligo di fare tutti, e singoli lavori, che occorreranno per le due Machine del pmo, e Secondo Fuoco, che S. Ecza il Sig.re Gran Contes.le D. Lorenzo Colonna Pne fà fare le due Sere delli 28, e 29 Giugno pros.ro in occ.e della funz.e della Chinea, Secondo il disegno, ed ordinazione, che mi verrà fatta dall'Architetto dell'Eccza Sua, e tutto detto lavoro, à riserva del Castello, che deve fare il Muratore, mi obligo e prometto di fare ad uso di mia arte, ed à tutta mia robba, Spese anche de Chiodi, e fattura, con che però l'Ecza Sua sia obligato di farmi consegnare tutto quel Legname vecchio, che si troverà in essere, e che altre volte è servito per detto uso, del qual Legname Io Sottos.to mi obligo di renderne esatto, e fedel Conto, e quello tutto restituire all'Ecza Sua, terminata, che Sarà la sudetta funzione, Siccome ancora mi obligo di dare, e consegnare tutto quell'altro Legname, che metterò in opera del proprio, e che potrà occorrere per detto lavoro, qual Legname si vecchio, che nuovo, che metterò in opera dovrà restare tutto à beneficio, e favore di S. Ecza, e non altrim.ti

Prometto in oltre, e mi obligo di fare à tutte mie Spese di robba, e fattura comes.a li tre Tramezzi dentro il Palazzo Farnese, la Rindiera Sopra il Portone, e tutti li Palchetti, tanto nel Portone, che dentro le Stanze terrene del med.o Palazzo Secondo il Solito perche così e non altrim.ti.

Ed in oltre mi obligo à dar di mano alli Portatori tutte le volte, che occorrerà, e che le verrà ordinato dal Sig.re Architetto.

E tutto detto lavoro mi obligo di farlo per il prezzo, e nome di prezzo in tutto di Scudi Cinquecento=mta da pagarsi di mano, in mano, che anderò facendo il sud.o lavoro, quale prometto, e mi obligo di farlo ad uso di buon arte, ed à contentamento del sud.o Architetto di S. Ecza, e per il tempo, che dal medemo mi verrà prescritto, e mancando di farlo, possa, e sia lecito all'Ecza sua di farlo fare à tutte mie Spese, danni, ed interessi, con espressa dichiarazione ancora, che terminata sarà la sud.a funzione, sia tenuto, ed obligato conforme prometto, e mi obligo di levare d'opera tutto il sud.o lavoro, e tale quale lo levarò, consegnarlo alli Minis.ri dell'Ecza sua, e non altrim.ti

E per osservanza di tutte, e Singole cose di Sopra descritte, obligo me Stesso beni, ed Eredi nella più ampla forma della Rev.da Cam.ra Ap.ca con tutte le Solite Clausole rinunciando acconsentendo unica In fede Questo di 8 Maggio 17 cinquantanove 
[signed] Giuseppe Alberici

4. Contract of the painters Giovanni Angelo Soccorsi and Giovanni Battista de' Rossi, 7 May 1759 (AC, I.A.436/14)

Con la presente da valere come publico, e giurato Istromento rogato per mano di publico Notaro Noi Sottoscri insolidum ci oblighiamo à favore dell'Illmo, ed Eccmo Sig.re G. Contestabile D. Lorenzo Colonna di dipingere, e dorare à tutte, e Singole nostre Spese, compresovi le Tirature delle Tele vecchie, e nuove, e bollette per inchiodarle, le due Machine de fuochi artificiali da farsi le due Sere della prossima futura funzione della Chinea, e dette Pitture farle con gesso Solamente, e Senza Calce, e con colori à norma delli Disegni à noi già esibiti, ed à contentam.to e piacere $\mathrm{dl}$ d.o Sig.re Paolo Posi Architetto, e così ancora rifrescare con pitture le due Fontane di Vino, e tutto compire, e perfezzionare per il tempo prefisso, in cui doveranno dette Machine ardersi, di modo, che in mancanza di nostro adempimento, tanto in fare d.o Lavoro, quanto in perfezzionarlo come Sopra, Sia Lecito à S. E. Il Sig.re Gran Contestabile far fare il tutto à maggior Spesa, ed à tutti danni, Spese, ed interessi di Noi Sottoscritti obligati, alli quali vogliamo esser tenuti, e ci oblighiamo Solidalmente di Soggiacere liberamente, perchè così

E tutto detto Lavoro ci oblighiamo di farlo per il prezzo in tutto di scudi DueCentosessanta=mta da pagarcisi da S. E. di mano in mano, che si anderà facendo detto Lavoro, Sempre però à contentamento di d.o Architetto, e non altrimenti, compresovi in d.a Somma le dorature, che doveranno farsi nelle riferite due Machine come Sopra à contentamento dl medesimo Sig.re Architetto, ed in tutte Singole parti, e luoghi, che dal medemo ci verranno ordinate, e non altrimenti. E per osservanza delle Sopradette cose oblighiamo noi Stessi, Beni, ed Eredi insolidum nella più ampla forma forma $[\mathrm{sic}]$ dlla Rda Cammera Apostolica con tutte le solite Clausole In fede Roma questi di 7 Maggio 1759

Io Gio: Angelo Soccorsi M.o ppa

Io Gio: Batta de Rossi M.o ppa

Andrea Dotti fui pnte Testimonio alla soprad.a Sottoscriz.ne M.o ppa

Io Filippo Mora fui pnte Testimonio comeS.a m.o propria

Io Gaetano Rusca fui pnte Testimonio comes.a m.o propria

5. Extraordinary bill of the painters Giovanni Angelo Soccorsi and Giovanni Battista de' Rossi, June 1759 (AC, I.A.436/28)

Conto di Lavori fatti, e ritoccati alli Fuochi di Farnese per la venuta dopo che fù messo sù il Fuoco rifatti tutti con ordine del Sig.re Paolo Posi Architetto Con Gio: Battista de Rossi, e Gio: Angelo Soccorsi Pittori

Nota di Lavori fatti, e ritoccati alli Fuochi di Farnese per la pioggia venuta dopo, che fù messo sù il Fuocho fatti tutti con ordine del Sig.re Paolo Posi Architetto 
2- Per aver ridipinto tutto il maschio di mezzo dove aveva fatto danno l'acqua

1:- Per aver rifatto molti merli, ritoccati in quà, e in là per causa dell'acqua sopra d.o maschio

1:20 Per aver ritinti tutti li sassi sotto d.o maschio

-30 Per aver ritoccati i Zoccoli delli due Cavalli $\quad-.60$

1:60 Per aver ritoccati li due Fortini delle Torri con le teste di Bove $\quad$ 2:80

2:- Per aver ritoccati li otto pezzi delle porte delle Torri $\quad 3: 20$

3:- Per aver rifatti quasi tutti, e due li ponti à causa dell'acqua colata da tutte le parti $\quad 5: 40$

-40 Per aver ritoccati li Sentinelli $\quad-.80$

1:50 Per aver ritoccati li trofei, e rifatti molti scudi di nuovo inargentati, e ridipinti

3:80 Per aver ritoccato tutti li parapetti, e rifatti molti pezzi di nuovo per tutto il giro del primo piantato

4:60 Per aver ritoccato tutto il primo piantato, e messo di nuovo dodici mascaroni d'oro, e ricavati di chiaro, e scuro

-80 Per aver rifatto tutti li sassi da terra, che giravano intorno

$22: 20$ [in another hand] tt.a d.a Machina

[in Giuseppe Palazzi's hand] Tarato il Sud.o Conto a suoi giusti Prezzi Importa Scudi Ventidue, e [baiocchi] $20 \mathrm{Mta}$

[in Giuseppe Palazzi's hand] Dico [scudi] 22:20 mta

[signed] Paolo Posi Arch:to

Il Nostro Comp:ta dia Credito nel Conto di Gio: Batta de Rossi e Gio: Angelo Soccorsi Pittori di Scudi Ventidue, e [baiocchi] $20 \mathrm{mta}$ sono per diversi lavori fatti fuori del Cottimo per Servizio delle due Machine de fuochi artificiali nel cor:te mese di Giugno, in occasione della Funzione della Chinea del pnte anno, a Tenore del pnte conto, e Sensa pregiudizio Di Casa li 30 Giugno 1759 / [signed] Lorenzo Colonna / [scudi] 22:20

6. Contract of the firework masters Francesco Scardovelli and Antonio Silici, 8 May 1759 (AC, I.A.436/17)

Noi sottos:ti colla presente dà valere, come publico, e giurato Istrom.to rogato per mano di qualsivoglia publico Notaro, ci oblighiamo di fare tutto l'artificio delle due machine de Fuochi artificiali che S: Ez:a L’Eccmo S:re Gran: Contes:le D: Lorenzo Colonna farà fare le due Sere della prosim:a funz:e della Chinea del cor:te anno, conforme è stato pratticato negl'anni scorsi per il pz:o, e nome di prez:o di scudi Quattrocentocinquantata=mta conchè Sua Ez:a sia tenuto di farci somministrare dalla sua Fortezza di Paliano Decine 120 incirca di Polvere fina, e Xñe 20 parimente incirca di Salnitro Sim:e alla rag:e di [scudo] Uno la Decina conforme il solito, e Noi Sottos:ti gli dovremo abbonare d.o prez:o nella Sud:a Somma di Scudi QuattroCentoCinquanta=e la rimanente somma la med:a Ez:a ce la farà somministrare, di mano, in mano, che anderemo facendo il Lavoro del sud:o artificiale conforme à pratticato nell'anni anteced.i, e per Osservanza di tutto ciò abbiamo sottos:to la 
presente di nra propria mano alla presenza delli Sottos:ti Testimonij In Fede questo di 8 Mag:o 1759

[signed] Franc:co Scardovelli

[signed] Antonio Silici

Io Filippo Mora fui pnte Testimonio comeSopra mano propria

Io Gaetano Rusca fui pnte à qnto sopra m.o pp.a

Luigi dè Sanctis fui pnte Testimonio à quanto Sopra m.o pp.a

\section{Contract of the architect Paolo Posi, 12 May 1760 (AC, I.A.445/17)}

Essendo che il Sig.re Paolo Posi siasi offerto di prender sopra di se, e far fare tutti, e singoli lavori di Muratore, Falegname, Pittore, Scultore, et altro, che potesse occorrere per la construzzione delle due Machine de Fuochi artificiali soliti farsi fare da S. Eccza il Gran Contestabile D. Lorenzo Colonna le due Sere delli 28, e 29 Giugno, in occasione della funzione della Chinea, à riserva però del solo Artificio, che si fà dalli Fuocaroli per il quale non intende di esser tenuto à cosa alcuna, ed essendosi l'E.S. degnata d'accettare la detta offerta, colla condizione di doversene di tal trattato formarne Apoca privata, in cui debba esprimersi, e dichierarsi $[s i c]$ tutto il convenuto sù di ciò quindi è, che colla presente da valere come publico, e giurato Istro. rogato per mano di qualsivoglia Notaro, il sud.o Sig.re Paolo Posi qui presente promette, e s'obliga di fare, e far fare le sud.e due Machine, che servir devono per li sud.i Fuochi Artificiali à tutta sua robba, Spese, e fattura per il prezzo come si dirà in appresso, e con l'Infrascritti patti, Capitoli, e condizioni cioe

Primo, che l'Eccmo Sig.re Gran Contestabile sud.o sia tenuto, et obligato di far consegnare al sud.o Sig.re Paolo Posi tutte, e singole robbe avanzate dalle Machine de Fuochi dell'anno passato, tali quali però si ritrovano, e nelli luoghi dove sono riposte, senza che sia tenuto à spesa alcuna di trasporto, ò altro, ma detto Sig.re Paolo Posi sia tenuto di riceverle nelli luoghi, ove si ritrovano, e quelle farle slocare, e trasportare à tutte, è singole sue Spese, dove le parerà, e piacerà perche cosi

$2=0$ Che detto Sig.re Paolo Posi ricevute, che avrà le sud.e robbe, sia tenuto, et obligato conforme promette e s'obliga di fare, ò far fare le due Machine, che servir dovranno per li Fuochi Artificiali da spararsi le due Sere delli 28, e 29 Giugno pross.ro secondo li Disegni presentati all'E.S., e dalla med.a approvati senza veruna minorazione, má più tosto augmentati, che diminuiti, e queste farli fare à tutte, e singole sue spese di robba e fattura per quello porterà e richiederà il lavoro di Muratore, Falegname, Pittore, Scultore, Incartatore, è lavoro de Cerchi, Ferraro, Stagnaro, Funaro, Festarolo, pzo de Chiodi, Bollette, Filo, Spille, e tutt'altro, che riguarda le med.e Machine, à riserva però del solo Artificio solito farsi dalli Fuocaroli, assumendosi inoltre detto Sig.re Paolo Posi il peso, é la Spesa del porto, riporto, mettitura in opera, e rimettitura di tutte, e singole cose, che servir dovranno per dette $\mathrm{Ma}$ chine, quali tutte dovranno farsi guardare, e custodire à spese del med.o Sig.re Paolo Posi per che cosi, e non altrim.ti

$3=0$ Che sia inoltre tenuto di fare, e far fare à tutte, e singole sue Spese gli Ornati di dette Machine, cioè Statue, Figure, Mascaroni, Festoni, Vasi, Fiori, e tutt'altro, che richiederà, e 
porterà il decoramento delle medesime Machine, secondo li Disegni sud.i, con dover anche soffrir la Spesa della doratura, et inargentatura, Colori, e tutt'altro, che richiederassi per la totale, e perfetta esecuzione delle med.e, perche cosi, e non altrimenti.

4=o Sicome nelle Apoche di Cottimo fatte nell'anni passati con il Falegname per li lavori delle sud.e Machine, gli si addossava il peso, et obligo di fare ancora à tutte, e singole sue Spese di robba, e fattura tutti li tramezzi dentro il Palazzo Farnese, la rindiera sopra il Portone, é tutti li Palchetti tanto nel detto Portone, che dentro le stanze Terrene del med.o Palazzo, così detto Sig:re Paolo Posi promette, e s'obliga oltre il lavoro ad uso di Falegname, che servir dovrà per le dette due Machine di fare, e far fare à tutte sue spese di robba, e fattura tutti quej tramezzi soliti farsi dentro detto Palazzo, la rindiera sopra il Portone del med.o, tutti li Palchetti tanto nel med.o Portone, che dentro le stanze Terrene dell'anzidetto Palazzo, e tutt'altro, che potrà occorrere, e richiederà l'opera di Falegname, secondo il solito, e come si é pratticato negl'anni passati, perchè cosi, e non altrimenti.

$5=0$ Che per quello riguarda il lavoro da farsi dalli Pittori, sia tenuto, et obligato di farlo fare con Gesso solamente, e senza Calce, e con Colori buoni, e che oltre la Pittura delle Machine, e suoi Ornati, sia tenuto, et obligato di far rifrescare con pittura le due Fontane del Vino secondo il solito, perche cosi, e non altrimenti.

$6=0$ Che sia tenuto, et obligato conforme promette, e si obliga di provedere à tutte, e singole sue Spese li Lampadari, Placche, Candele di Sevo da Stampa, et ordinarie, ed altro che servir dovrà per l'Illuminazione delle sopradette due Machine, sia ancora tenuto di fare, e far fare il Palco, e comodo per li Sonatori, che dovranno sonare le Sinfonie le due Sere della Funzione, come ancora dovrà provedere Arazzi, et altro, che potrà occorrere, non solo per Ornato delle med.e due Machine, mà ancora, che potranno bisognare per riparare li danni, che per causa di Pioggia, e per qualunque altro motivo potessero accadere, è tutti, e quali danni promette, e s'obliga di riparare, et à proprie Spese risarcirli, perche cosi, e non altrimenti.

$7=0$ Promette inoltre, e s'obliga di provedere à tutte, e singole sue Spese le Torce à Vento, che occorreranno per mettere in opera, e dismettere le riferite due Machine, perche cosi, e non altrimenti.

$8=o$ Che S. Ecc.za il Gran Contestabile D. Lorenzo Colonna Prone sia tenuto, et obligato di farle somministrare oltre le robbe descritte nel primo Capitolo della presente Apoca tutta quella Tela nuova, che potrà occorrere per la struttura, e composizione delle med.e Machine, niente però di più dell'occorrente, perche cosi, e non altrimenti.

$9=0$ Sparato, che sarà l'Artificio delle dette due Machine le due Sere della funzione della Chinea, e compita, che sarà la med.a funzione, sarà cura, e peso di detto Sig.re Paolo Posi di far dismettere le dette due Machine, à tutte, e singole sue Spese, con fare levare d'Opera, trasportare, riporre, e locare ne luoghi soliti tutto ciò, che sarà servito per la composizione delle med.e, con doversene prima fare esatta descrizione, dovendo il tutto, niente eccettuato, restare à favore, è comodo dell'E.S. perche cosi, e non altrimenti.

$10=0$ Sarà per fine tenuto, et obligato detto Sig.re Paolo Posi di mettere à tutte, e singole sue Spese tanti Uomini di Guardia, quanti ne potranno occorrere per la conservazione, e custodia di tutte le robbe, Statue, Tele, Telari, Ornati, ed altro, che sarà servito per la composizione 
delle sopradette due Machine, e ciò per evitare qualunque danno, e furto, che potesse accadere tra la confusione, è folla del Popolo solita seguire dopo lo sparo dell'Artificio delle med.e Machine, e trovandosi qualche cosa mancante dovrà esser tenuto del proprio, e farne buono il pzo all'E.S. perche cosi, e non altrimenti.

11=o Per tutti poi, e singole di sopra descritti lavori, e Spese niuna eccettuata, e di ogn'altra cosa che servir dovrà per le riferite due Machine anche nel presente Obligo non espressa, $\mathrm{e}$ che fosse necessario da esprimersi, l'E.S. promette, e s'obliga di farli pagare la concordata Somma di Scudi Milleduecentoquaranta $=\mathrm{mta}$, in tutto, é per tutto, é questa fargliela pagare in più paghe, e secondo si verrà facendo il lavoro, perche cosi, e non altrimenti.

12=o E per osservanza di tutte, e singole cose espresse di sopra, detto Sig.re Paolo Posi obliga se stesso, Beni, et Eredi nella più Ampla forma della Rev: Cam.ra Aplica con tutte le solite Clausole, rinunciando, acconsentendo, unica, in fede questo di 12 Maggio 17sessanta

[signed] Paolo Posi Arch:o

8. Letter from Lorenzo Colonna to Bernardo Tanucci, 29 June 1759 (AC, II.GG.4 1759, num. 64)

Eccellenza

Sig.re Marchese Tanucci/Napoli

29 Giugno 1759

A Sua Eccellenza Il Sig:re Marchese Dn Bernardo Tanucci

Napoli

Perche più serie faccende non permetterebbero a V.E. di leggere senza tedio, e perchè la presente giornata non lascia a me il comodo di stendere una circonstanziata relazione dell'Ambasceria straordinaria di cui è piaciuto al Re Nro Sig.re d'onorarmi presso il regnante Sommo Pontefice, mi permetta di grazia L'Eccza Vra, che Io mi ristringa ad assicurarla: Che la Funzione è riuscita in ogni sua parte con la solita proprietà, decoro e magnificenza: Che il concorso del popolo spettatore alla mia comparsa ed ai fuochi d'allegrezza è stato innumerabile: Che non v'è stata persona di rango sì Ecclesiastico, che secolare, la quale non sia venuta personalm.te o per mezzo de suoi gentiluomini al Corteggio nella gita a S. Pietro e nel Palazzo Farnese per dimostrare la propria venerazione ed attaccamento verso un tanto Re; e che finalmente il Santo Padre intenerito all'udir da me, nell'atto di presentargli la consueta Chinea, gli attestati della reale insigne pietà, e somma divozione verso la Santa Sede, e verso la Sagra persona di Sua Bne con espressioni corrispondenti di gradimento, e di sincerissimo paterno affetto, ha dato alla M.S. ed a tutta la reale Famiglia l'Apostolica Benedizione

Adempiuto così all'obbligo, che mi corre non mi resta, che di pregare, come rispettosamente faccio, Vra Eccza d'umiliare questa notizia a S. M.tà, e d'intercedermi un generoso compatimento alle mie debolezze nell'adempiere i sovrani suoi Ordini, e col solito inviolabile ossequio mi protesto per sempre

Di V.E. 
9. Letter from Bernardo Tanucci to Lorenzo Colonna, 3 July 1759 (AC, II.GG.4 1759, num. 65)

\section{Eccellenza}

Conoscendo il Rè N.S. per pruova [sic] il Zelo, la fervida applicazione, e l'attaccamento di VE per il Suo Real Servigio, non è punto giunta nuova alla MS. l'adeguatezza, con cui ha Ella disimpegnata l'Incaricatale Ambasceria Straordinaria di S.M. presso il Sommo Pontefice per l'atto della ricorsa presentazione della consueta Chinea. Ne hà quindi il Rè ascoltato con sodisfazione i riscontri datimi dall'EV. sulla giuliva, e tranquilla riuscita della funzione. E si è altresì compiaciuta dell'attenzione di Cod.a Nobiltà sì Ecclesiastica, che secolare in concorrere à Condecorare l'atto di sua esemplarissima divozione verso la Santa Sede. Ma sopratutto è rimasto il Reale suo religioso animo intenerito sul contesto, che V.E. ne hà dato della Paterna Pontificia accoglienza.

Essendo dunque riuscito il tutto a seconda delle sovrane Intenzionj di S.M., mi comanda testimoniarne all'EV. il pieno suo gradimento. Conti pur Ella sù questo, e sulla graziosa benevolenza con cui il Rè riguarda la degna Persona di VE., mne io prendo tutto il piacere in eseguire questi ordini della MS. Porticj 3 Luglio 1759.

Ecc:mo Sig:re

Bernardo Tanucci 


\section{Bibliography}

ABBREVIATIONS

$\mathrm{AC}$

AGS, SE

$\mathrm{AN}, \mathrm{AE}$

AS, AER

AS, LM

AS, MP

AS, SDR

BAV

Chracas

ÖS, RK
Subiaco, Monumento Nazionale di S. Scolastica, Biblioteca Statale, Archivio Colonna Simancas, Archivo General de Simancas, Secretería de Estado

Paris, Archives Nationales, Affaires étrangères, Correspondance consulaire, Rome

Naples, Archivio di Stato, Affari esteri, Roma

Turin, Archivio di Stato, Lettere ministri, Roma

Florence, Archivio di Stato, Mediceo del Principato

Venice, Archivio di Stato, Senato, Dispacci di Roma

Vatican City, Biblioteca Apostolica Vaticana

Chracas, Diario ordinario, newspaper published in Rome discontinuously between 1716 and 1834

Vienna, Österreichisches Staatsarchiv, Abteilung Haus-, Hof- und Staatsarchiv, Rom-Korrespondenz

\section{WORKS CITED}

Diderot, D., and J. d'Alembert, eds., Encyclopédie, ou dictionnaire raisonné des sciences, des arts et des métiers, 35 vols., facsimile ed. (Stuttgart 1967).

[École Française de Rome], Le Palais Farnèse, vol. 2, Planches (Rome 1980).

Entrata e spesa generale della ven. Archiconfraternità ed Ospedale della Santissima Trinità de'

Pellegrini, e Convalescenti di Roma per l'anno santo 1775 (Rome 1776).

Fagiolo, M., ed., La festa a Roma dal Rinascimento al 1870, exh. cat., 2 vols. (Turin 1997).

Fagiolo dell'Arco, M., La festa barocca, vol. 1 of Corpus delle feste a Roma (Rome 1997).

Gori Sassoli, M., Della Chinea e di altre "Macchine di gioia." Apparati architettonici per fuochi d'artificio a Roma nel Settecento, exh. cat. (Milan 1994).

[Grosley, P.-J.], Observations sur l'Italie et sur les Italiens, données en 1764, sous le nom de deux Gentilshommes Suédois, 4 vols. (London 1770).

Gross, H., Rome in the Age of Enlightenment: The Post-Tridentine Syndrome and the Ancient Regime (Cambridge 1990).

Kelly, C. C., "Ars moriendi in Eighteenth-Century Rome: Papal and Princely Catafalques: The Contribution of Paolo Posi," in "All the world's a stage. . .": Art and Pageantry in the Renaissance and Baroque, ed. B. Wisch and S. S. Munshower (University Park, Pa. 1990) 580-619.

Liberati, F., Il perfetto mastro di casa (Rome 1658).

Mallory, N. A., "Notizie sulla scultura a Roma nel XVIII secolo," Bollettino d'arte 59.3-4 (1974) $164-77$.

Michel, G., "Vie quotidienne au Palais Farnèse (XVIIe-XVIIIe siècle)," in [École Française de Rome], Le Palais Farnèse, vol. 1.2 (Rome 1981) 509-65.

Michel, O., “'L'accademia," in [École Française de Rome], Le Palais Farnèse, vol. 1.2 (Rome 1981) 567-611.

Moore, J. E., "Prints, Salami, and Cheese: Savoring the Roman Festival of the Chinea," Art Bulletin 77 (1995) 584-608.

Nugent, T., trans., [P.-J. Grosley], New Observations on Italy and Its Inbabitants, 2 vols. (London 1769).

Pastor, L. von, History of the Popes, vols. 35-36 (London 1949-50).

Pinto, J. A., The Trevi Fountain (New Haven, Conn. 1986). 
Pollak, O., “Der Architect im XVII. Jahrhundert," Zeitschrift für Geschichte der Architektur 3 (1910) 201-10.

Salatino, K., Incendiary Art: The Representation of Fireworks in Early Modern Europe (Los Angeles 1997).

Scavizzi, C. P., Edilizia nei secoli XVII e XVIII a Roma. Ricerche per una storia delle tecniche (Rome 1983).

Sievernich, G., ed., Das Buch der Feuerwerkskunst. Farbenfeuer am Himmel Asiens und Europas (Nördlingen 1987).

Strazzullo, F, ed., Le lettere di Luigi Vanvitelli della Biblioteca Palatina di Caserta, 3 vols. (Galatina 1976-77).

Utile distribuito dalla Santità di Nostro Signore Papa CLEMENTE XII. Felicemente Regnante come si è detto di contro (Rome 1733).

von Rohr, J. B., Einleitung zur Ceremoniel-Wissenschaft der grossen Herren (Berlin 1733).

Zabaglia, N., Castelli, e Ponti di Maestro Niccola Zabaglia con alcune ingegnose pratiche, e con la descrizione del trasporto dell'Obelisco Vaticano, e di altri del Cavaliere Domenico Fontana (Rome 1743). 